\title{
Performance Evaluation of Soil Cell
}

\author{
By \\ Lianghao Chen \\ BEng. Ryerson University, Toronto, Canada, 2014
}

A thesis presented to

Ryerson University

in partial fulfilment of

the requirement for the degree of

Master of Applied Science

in the program of

Civil Engineering

Toronto, Ontario, Canada, 2019

(C) Lianghao Chen, 2019 


\section{AUTHOR'S DECLARATION FOR ELECTRONIC SUBMISSION OF A THESIS}

I hereby declare that I am the sole author of this thesis. This is a true copy of the thesis, including any required final revisions, as accepted by my examiners.

I authorize Ryerson University to lend this thesis to other institutions or individuals for the purpose of scholarly research

I further authorize Ryerson University to reproduce this thesis by photocopying or by other means, in total or in part, at the request of other institutions or individuals for the purpose of scholarly research.

I understand that my thesis may be made electronically available to the public. 


\begin{abstract}
Performance Evaluation of Soil Cell

Lianghao Chen, Master of Applied Science in Civil Engineering, Ryerson University, Canada, 2019

Soil Cell is a novel Low-Impact Development practice that is suitable for densely developed urban environment.

This thesis seeks to gain further understanding of soil cell's performance in terms of water quality and quality control; and to assess the exfiltration performance of perforated pipe in soil cells by monitoring an active cell.

The monitoring result showed that the cell was very effective in treating particulate $(90 \%$ concentration reduction), metal (91\% lead concentration reduction to 53\% copper concentration reduction) and phosphorus (74\% concentration reduction). The cell was ineffective in treating chloride (1\% concentration increase, no statistical significance) and even caused nitrate leaching ( $65 \%$ concentration increase).

Field performance of the soil cell indicated that the inflow perforated backed up frequently, restricting the flow into the cell but laboratory testing of the perforated pipes' hydraulic performance confirms that the pipe has a sufficient capacity to convey the flows of up to $10 \mathrm{~L} / \mathrm{s}$.
\end{abstract}




\section{Acknowledgements}

I would like to express my gratitude to Dr. Darko Joksimovic and my co-supervisor Dr. James Li for the guidance they provided during my pursuit of knowledge, for which I will always be grateful.

The author would also like to thank the City of Toronto, who provided the equipment and the soil cell as well as its financial support, and Armtec who provided the perforated pipe used in the construction of the physical model.

I would like to show my appreciation to my friends and family whose emotional support was most valuable.

Finally, I would like to acknowledge Abbas Kazemi for proofreading the thesis. 


\section{Table of Contents}

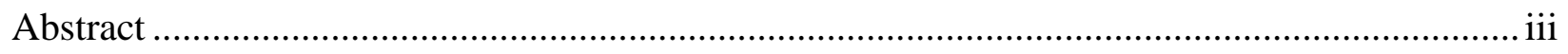

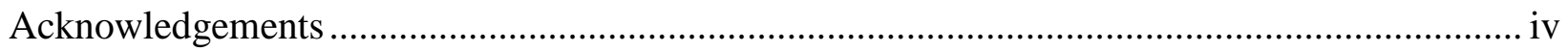

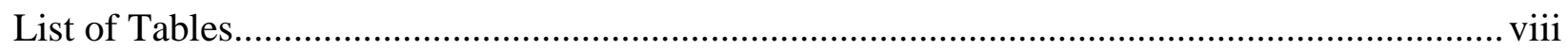

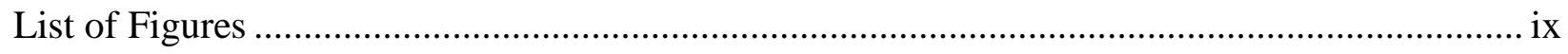

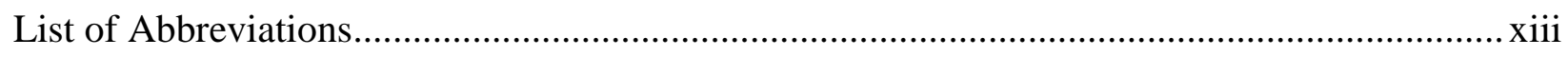

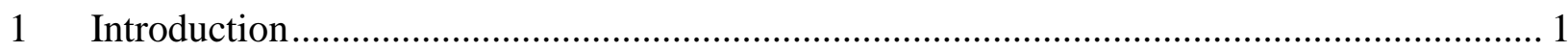

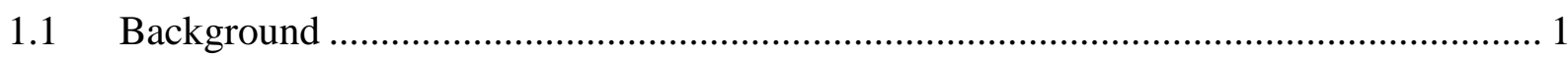

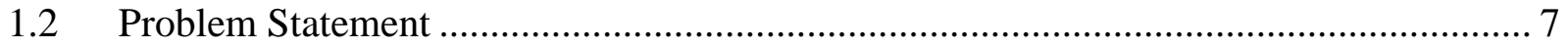

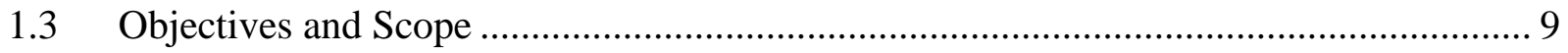

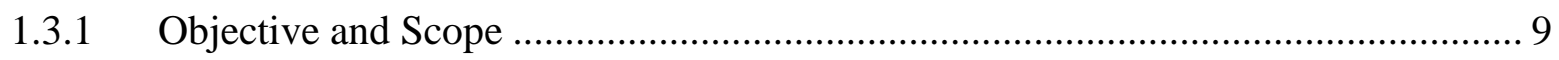

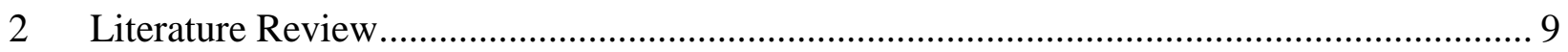

2.1 Performance and Design of Bioretention Cells ........................................................... 10

2.1.1 Bioretention Design ....................................................................................... 10

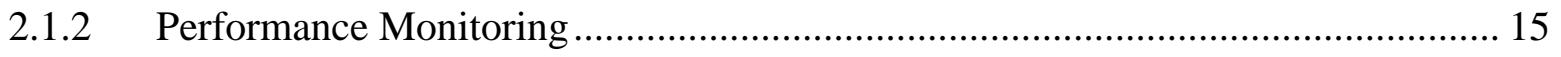

2.1.3 Source of Pollutants in Stormwater ..................................................................... 19

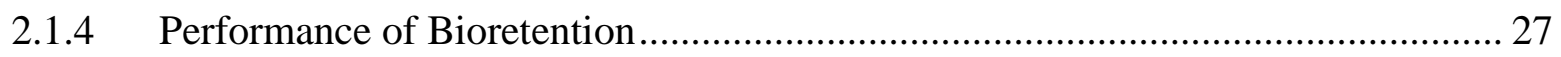

2.1.5 Conclusion for Literature on Bioretention ............................................................ 31

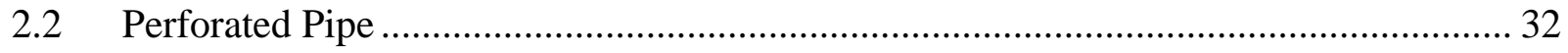




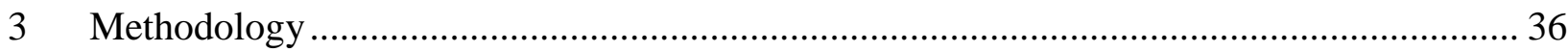

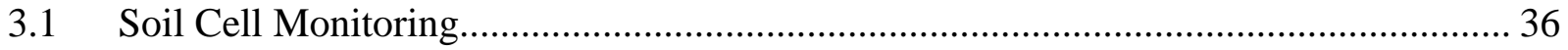

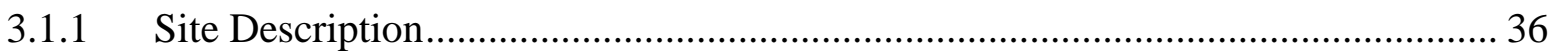

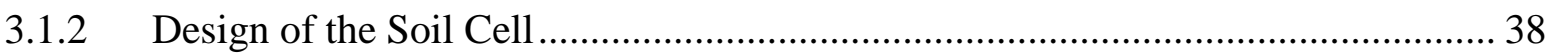

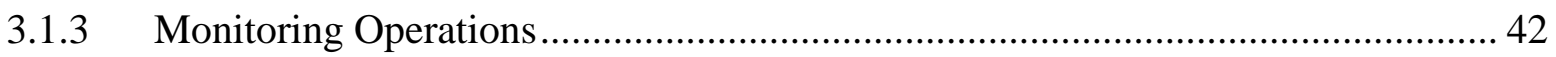

3.2 Hydraulic performance of Perforated Pipe................................................................... 47

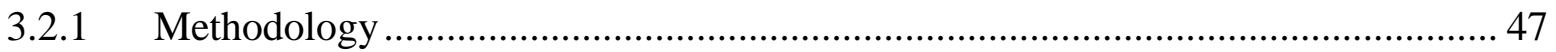

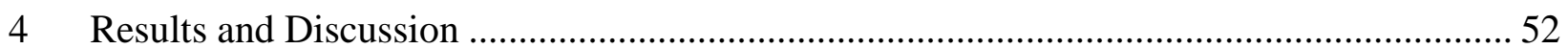

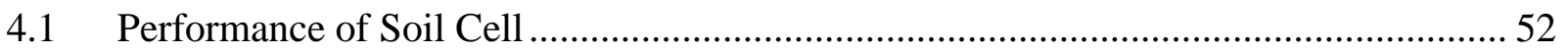

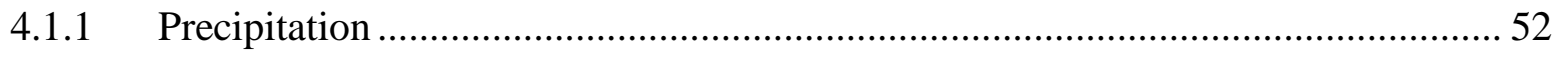

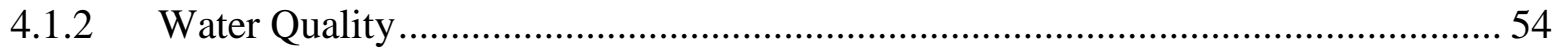

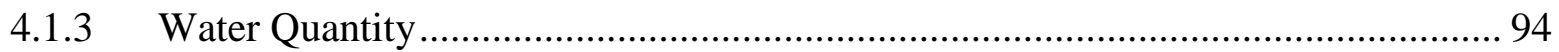

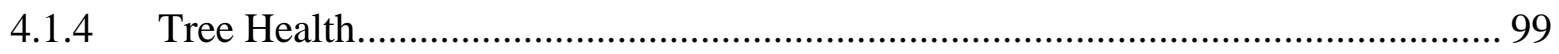

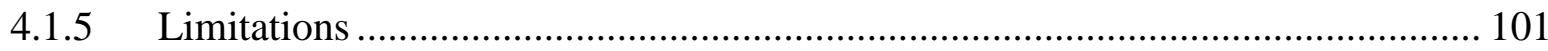

4.2 Hydraulic Performance of Perforate Pipes............................................................. 102

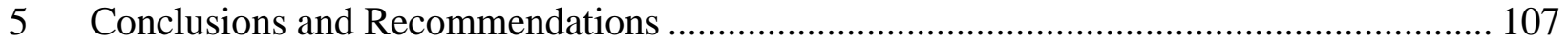

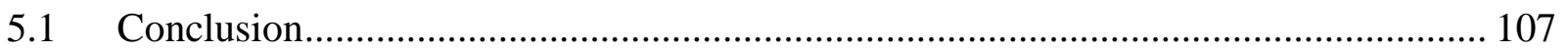

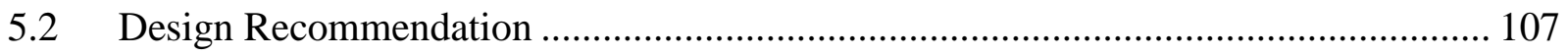

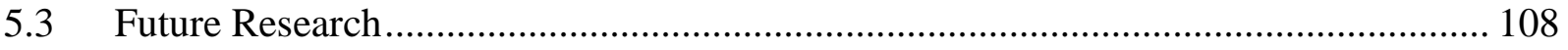

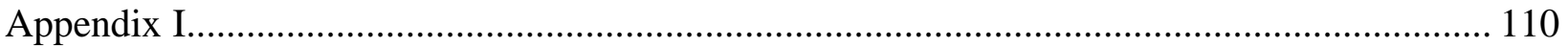


Appendix II

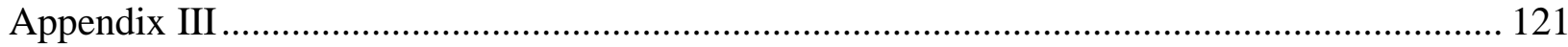

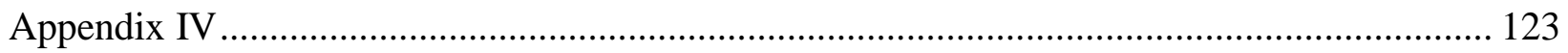

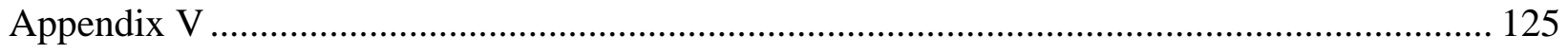

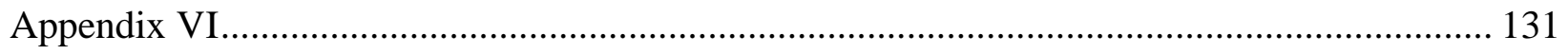

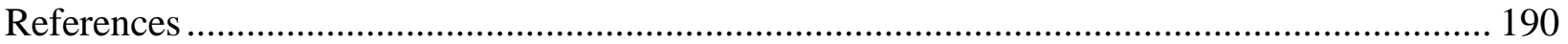




\section{List of Tables}

Table 1. Composite of $63 \mu \mathrm{m}$ Particles by Mass in Wisconsin .....

Table 2. Summary for Stormwater Quality Treatment Performance of Bioretention Cells as per

International Stormwater BMP database ............................................................................... 28

Table 3. Water Balance in Bioretention Cell at Living City Campus, Adapted from ................. 30

Table 4. Pollutants Analyzed in the Monitoring Operation ...................................................... 44

Table 5. List of Equipment Used in Monitoring Operation, and Equipment's Locations and

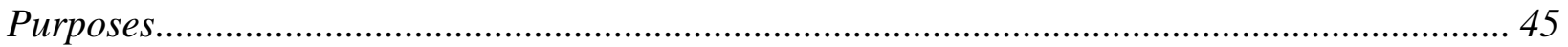

Table 6. 6-Inch AASHTO M252 Type C Dimensions........................................................... 48

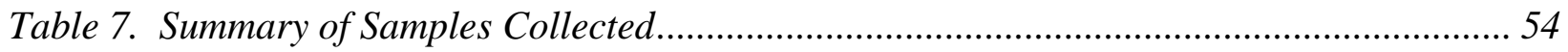

Table 8. Statistical Summary of Influent and Effluent Concentration ..................................... 55

Table 9. Coefficient of Correlation Between Influent and Effluent for Metal Concentration ..... 66

Table 10. Statistical Summary of Influent and Effluent Dissolved Metal Concentration ............ 74

Table 11. Pollutant Concentration Reduction Comparison between Soil Cell and Bioretention

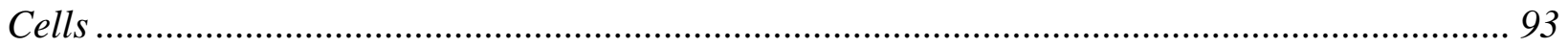

Table 12. Tree Crown Spread Measurements................................................................... 100 


\section{List of Figures}

Figure 1. Pre-Development Hydrograph vs Post-Development Hydrograph............................ 1

Figure 2. Mimico Creek During Dry Weather (Left) and After Light Rain ................................ 3

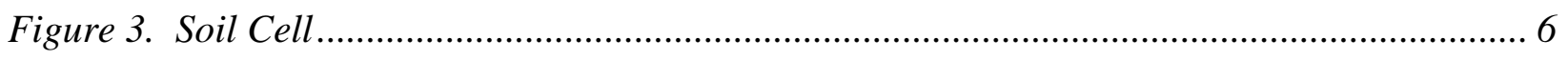

Figure 4. Typical Infiltration / Recharge Bioretention Cell Cross Section ............................... 11

Figure 5. Typical Filtration / Partial Recharge Bioretention Cell Cross Section...................... 12

Figure 6. Typical Infiltration / Filtration / Recharge Bioretention Cell Cross Section .............. 12

Figure 7. Typical Filtration Only Bioretention Cell Cross Section........................................ 13

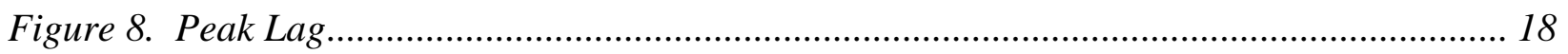

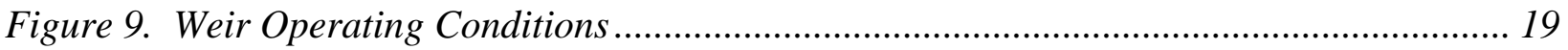

Figure 10. Mechanisms of Pollutant Accumulation on Roads............................................... 20

Figure 11. Experiment Apparatus Used by Duchene and McBean ....................................... 33

Figure 12. Profile and Cross Section of Perforated Pipes ..................................................... 33

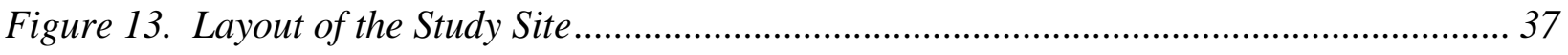

Figure 14. Inlet Drainage Basin of the Soil Cell ................................................................ 38

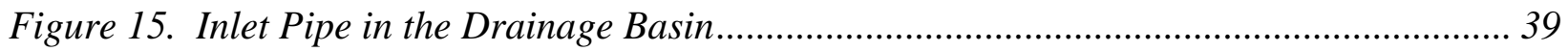

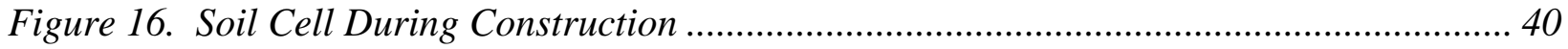

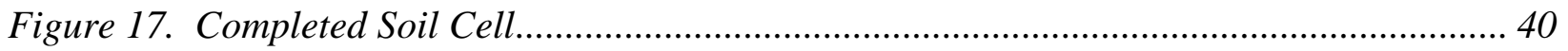

Figure 18. Configurations of Trees in Soil Cells .................................................................. 41

Figure 19. Particle Size Distribution of the backfill material. ................................................ 41

Figure 20. Typical Drawing of AASHTO M252 Type C Pipe ................................................ 47

Figure 21. Perforation Pattern of the Pipe Used in The Experiment ...................................... 48 
Figure 22. Exfiltration Pipe Experiment Apparatus Schematic.............................................. 49

Figure 23. Exfiltration Pipe Experiment Apparatus Photo ................................................. 51

Figure 24. 2016 Monthly Rainfall Compare to Historical Record (1961-2012)...................... 52

Figure 25. Cumulative Distribution of Daily Rainfall Depth as Percentage of Typical Annual

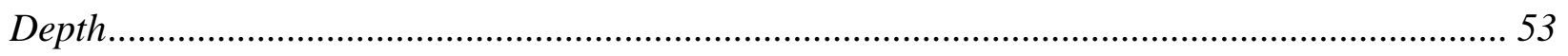

Figure 26.Total Suspended Solid Concentration Comparison ............................................... 56

Figure 27. Pair Wise Comparison for TSS .................................................................... 57

Figure 28. Temporal Distribution of TSS Reduction, TSS and Chloride Loading in 2016 ........ 58

Figure 29. Aluminium Concentration Comparison ............................................................. 60

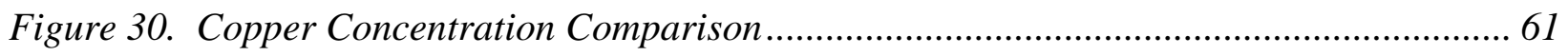

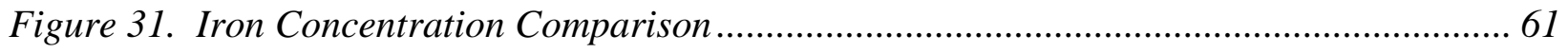

Figure 32. Total Lead Concentration Comparison ........................................................... 62

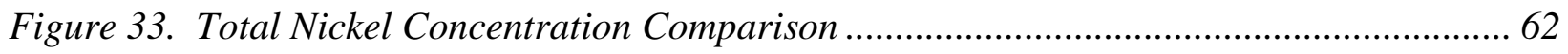

Figure 34. Zinc Concentration Comparison ................................................................... 63

Figure 35. Pair Wise Comparison for Aluminum .............................................................. 63

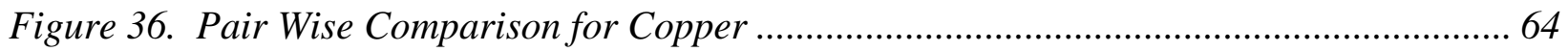

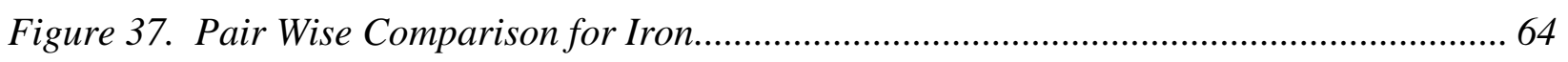

Figure 38. Pair Wise Comparison for Lead ................................................................. 65

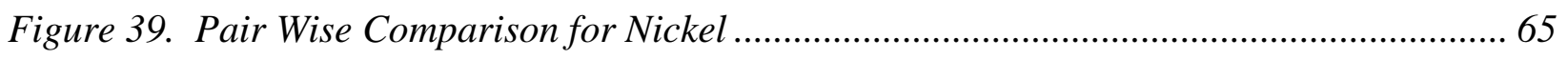

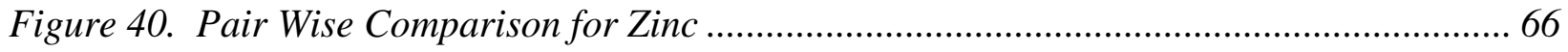

Figure 41. Aluminum Influent and Effluent Concentration vs Influent Chloride Concentration 67

Figure 42. Copper Influent and Effluent Concentration vs Influent Chloride Concentration..... 67

Figure 43. Iron Influent and Effluent Concentration vs Influent Chloride Concentration.......... 68 
Figure 44. Lead Influent and Effluent Concentration vs Influent Chloride Concentration......... 68

Figure 45. Nickel Influent and Effluent Concentration vs Influent Chloride Concentration ...... 69

Figure 46. Zinc Influent and Effluent Concentration vs Influent Chloride Concentration ......... 69

Figure 47. Dissolved Aluminum Concentration Comparison............................................... 70

Figure 48. Dissolved Copper Concentration Comparison ................................................. 71

Figure 49. Dissolved Iron Concentration Comparison ......................................................... 71

Figure 50. Dissolved Lead Concentration Comparison ....................................................... 72

Figure 51. Dissolved Zinc Concentration Comparison ......................................................... 72

Figure 52. Chloride Concentration Comparison................................................................. 78

Figure 53. Pair Wise Comparison for Chloride ................................................................. 79

Figure 54. Temporal Distribution of Chloride Reduction and Influent Concentration.............. 80

Figure 55. Temporal Distribution of Chloride Reduction and Influent Concentration During

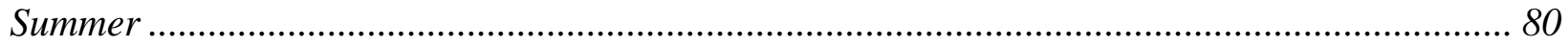

Figure 56. Biochemical Oxygen Demand Concentration Comparison ................................... 81

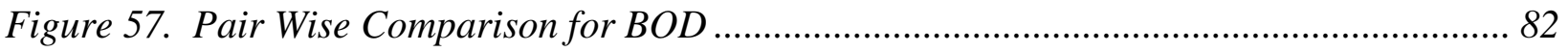

Figure 58. Temporal Distribution of BOD Concentration reduction ...................................... 83

Figure 59. Leaves Matter on the Road in the Catchment Area ............................................. 84

Figure 60. Phosphorus Concentration Comparison .......................................................... 85

Figure 61. Phosphorus Concentration Comparison.......................................................... 85

Figure 62. Temporal Distribution of Total Phosphorus Concentration Reduction.................... 86

Figure 63. Nitrate Concentration Comparison.................................................................... 87

Figure 64. Nitrate Concentration Comparison............................................................... 87

Figure 65. Temporal Distribution of Nitrate Concentration Reduction .................................... 88 
Figure 66. Water Level and Moisture Plot on August 16, 2016 ........................................ 90

Figure 67. Summary Plot for November 28 Event ................................................................ 91

Figure 68. Summary Plot for November 30 Event ........................................................... 92

Figure 69. Estimated Runoff vs Measured Runoff ............................................................... 96

Figure 70. Example of Inlet Backup and Outlet Leak.......................................................... 98

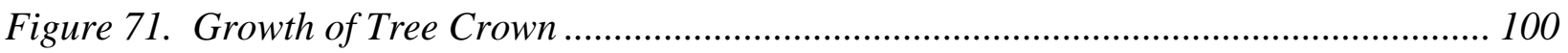

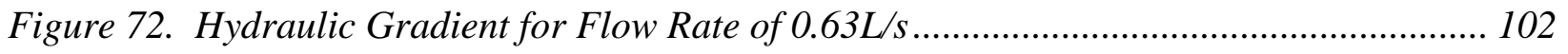

Figure 73. Hydraulic Gradient for Flow Rate of 1.01 L/s .................................................... 103

Figure 74. Hydraulic Gradient for Flow Rate of 2.02 L/s ................................................. 103

Figure 75. Hydraulic Gradient for Flow Rate of 4.04L/s ................................................. 104

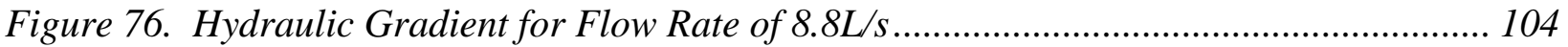

Figure 77. Hydraulic Gradient for Flow Rate of 10.28L/s.............................................. 105 


\section{List of Abbreviations}

$\begin{array}{ll}\text { AASHTO } & \text { American Association of State Highway and Transportation Officials } \\ \text { BOD } & \text { Biochemical Oxygen Demand } \\ \text { DO } & \text { Credit Valley Conservation Authority } \\ \text { EMC } & \text { Dissolved Oxygen } \\ \text { GPM } & \text { Gallons per Minute } \\ \text { HDPE } & \text { High-Density Polyethylene } \\ \text { I.D } & \text { Inside Diameter } \\ \text { LID } & \text { Low Impact Development } \\ \text { NCDEQ } & \text { North Carolina Department of Environmental Quality } \\ \text { O.D } & \text { Outside Diameter } \\ \text { PSD } & \text { Particle Size Distribution } \\ \text { TRCA } & \text { Toronto and Region Conservation Authority } \\ \text { TSS } & \text { Total Suspended Solids }\end{array}$




\section{Introduction}

\subsection{Background}

Intense urban development has been identified as a cause of deterioration of urban streams. This phenomenon is known as "Urban Stream Syndrome” (Walsh et al. 2005). Urban development replaces naturally pervious surfaces such as meadows and farmland with impervious surfaces such as roads, parking lots and roofs. These surfaces disrupt the natural water cycle by preventing stormwater from infiltrating into native soil thereby increasing surface runoff. A typical stream in an urban environment exhibits a hydrograph with a higher and faster peak flow rate with a subsequently shorter descending arm (Walsh et al. 2005) when compared to a natural stream. This is illustrated by Figure 1.

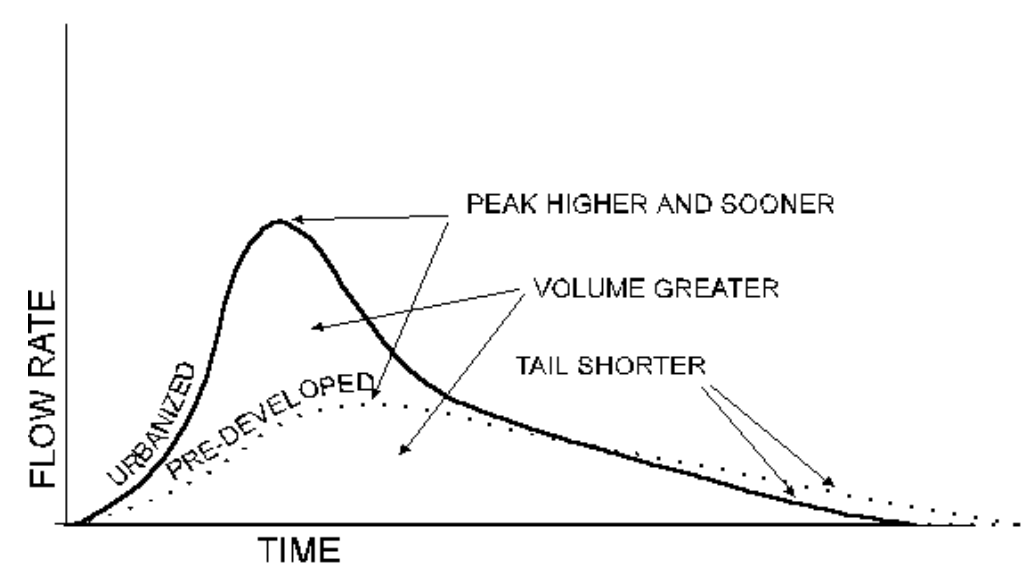

Figure 1. Pre-Development Hydrograph vs Post-Development Hydrograph(Walsh et al. 2005).

In addition to preventing infiltration, road surfaces are also a major non-point source of water pollution, and land contamination. This is a result of pollutants, such as metal resulting from vehicle traffic, are deposited onto the surface during dry weather, that are eventually washed into the aquatic environment during storm events (Walsh et al., 2005). Road surfaces such as asphalt 
can absorb heat during hot weather which then elevates the temperature of road runoff during storm events (Omidvar et al. 2018).

The traditional focus of stormwater management is flood prevention, where stormwater is considered as a nuisance that can cause damage to properties such as basements in houses, and public infrastructures such as roads, and is to be removed as quickly as possible from the source via storm sewers and discharged into natural bodies of water. Therefore, the natural water cycle is disturbed, the runoff is no longer return to the water table but discharged into the urban streams quickly, preservation of the natural water cycle was neglected in the traditional approach.

The shortcomings of traditional stormwater management practice results in the significantly deteriorated urban stream. The frequent surging results in accelerated bank erosion, wash-off of pollutants causes the deterioration of water quality and fluctuating temperature negatively affects the aquatic species (TRCA and CVC 2010).

The water quality deterioration and accelerated rate of bank erosion due to rain events can be observed in Mimico Creek located in west Toronto and illustrated in Figure 2. The dry weather flow is shown on the left figure and the wet weather flow is shown on the right. As it can be seen on the left, water quality appears good as the turbidity is low and the flow is shallow. Bank erosion can be observed as tree roots can be seen near the water edge in the left figure. The right half of the figure illustrates the creek's response to a minor storm event. A rain event of $3.9 \mathrm{~mm}$ on June 11,2016 , lead to a significant increase in turbidity and increase in flow rate, the increased flow depth can be observed to scour the river bank. 


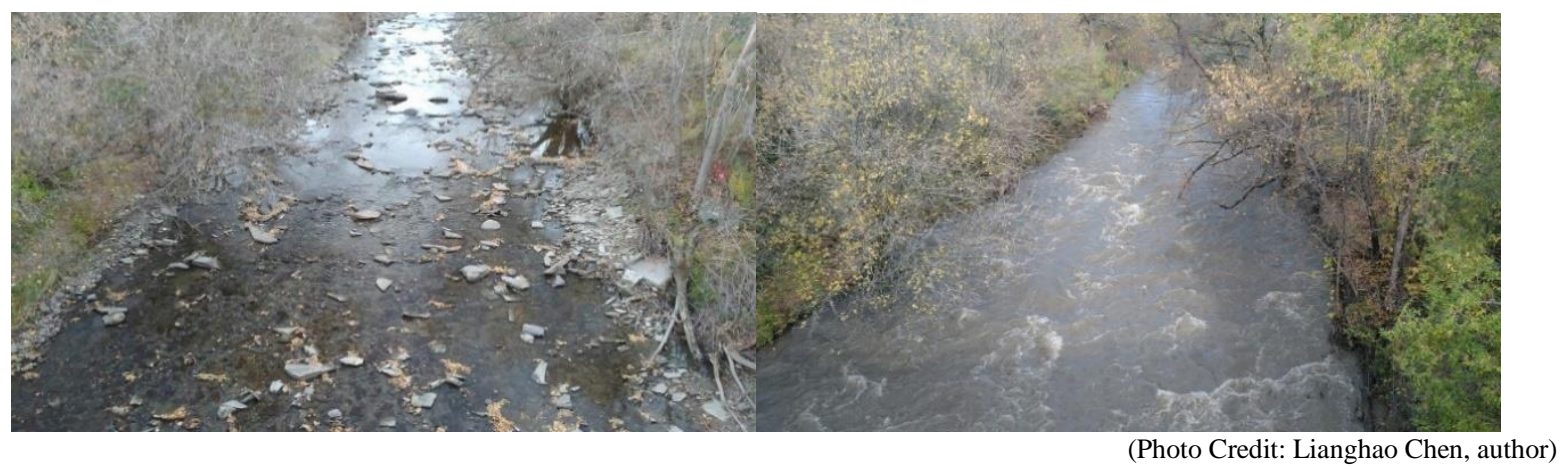

Figure 2. Mimico Creek During Dry Weather (Left) and After Light Rain (Right)

The detrimental effect of neglecting stormwater management is self-evident, and it is the impetus for an evolution in stormwater management practice.

In Ontario, the current scope for stormwater management have evolved to include the preservation of natural stormwater runoff characteristics, quality and quantity as a part of its scope. This shift is reflected in the Stormwater Management Planning and Design Manual published by the Ministry of Environment of Ontario in 2003. This guideline sets following objectives for the management of stormwater (Ontario and Ministry of the Environment 2003):

- Groundwater and baseflow characteristics are preserved;

- Water quality will be protected;

- The watercourse will not undergo undesirable geomorphic change;

- There will not be any increase in flood damage potential; and ultimately

- That an appropriate diversity of aquatic life and opportunities for human uses will be maintained.

An emerging trend adopted by many government agencies to meet these objectives is the treatment train approach (TRCA and CVC 2010). This approach as defined by City of Toronto's Wet Weather Flow Management Master Plan consists of the following three stages (City of Toronto 2006): 
1. Source Control: As the priority in the Treatment Train approach, stormwater should be captured as close to its source, treated and infiltrated into the ground to mimic natural water cycle such that the groundwater and baseflow characteristics are preserved.

2. Conveyance Control: Stormwater exceeding the capacity of source control device need to be conveyed away eventually into the natural bodies of water. Treatment and infiltration should be provided along the way further mimicking natural water cycle further.

3. End-of-Pipe Solutions: A final treatment should be provided before stormwater is discharged into natural water bodies.

This approach is also widely adopted by other agencies overseeing stormwater management across the world including Toronto Region Conservation Authority, Minnesota Pollution Control Agency (City of Toronto 2006; Minnesota Pollution Control Agency 2018; Ontario and Ministry of the Environment 2003; TRCA and CVC 2010).

One category of infrastructure utilized to achieve the goals stated in Treatment Train Approach is called Low Impact Development (LID), they can include a wide range of devices and implementations including rain barrels, green roofs, and bioretention cells. LID devices can operate on different principles, but they typically achieve at least one of following functions in stormwater control:

- Attenuation: Stormwater is captured and held in the device and released slowly into the storm sewer or diverted. This process can contribute to the delay and reduction of peak flow rate of urban streams. An example of a device that utilizes attenuation would be the Rain Barrel. This device stores the rainwater, and releases it for irrigation during dry weather. 
- Filtration: Stormwater is filtered through the LID practice, removing some pollutants. This improves the quality of stormwater. An example of a device that utilizes filtration would be bioretention cells. These take the polluted stormwater and filter it through an engineered soil medium.

- Infiltration: The device is constructed of a highly permeable material and promotes the infiltration of stormwater into the ground. This mechanism contributes to the restoration of natural water cycle at a site to one that mimics the pre-development condition. Bioretention cells appropriately deployed can also serve in this capacity.

Compliance with the Treatment Train Approach is now an integral part of current development approval process in many jurisdictions including Toronto. The deployment of LID practices as a part of landscape architecture are now common in urban developments (Kratky et al. 2017; TRCA and CVC 2010).

Bioretention cells have demonstrated to be an effective LID practice (TRCA and CVC 2010). They are typically used as small-scale source control infrastructure, which receive runoff from impervious surfaces such as roads and parking lots. They are constructed landscape features consisting of an excavated space backfilled with layers of engineered soil medium which support vegetation. Design features such as underdrains can also be installed depending on site condition (e.g. poor soil drainage). As previously mentioned in Section 1.1, bioretention cells are useful in both filtration and infiltration. The stormwater is collected and filtered through the soil layer then infiltrated into the native soil. Pollutants are retained via a combination of physical, chemical and biological processes, which is discussed in 2.1.3. Some stormwater can be attenuated in the soil medium as moisture as well and returned to the atmosphere via evapotranspiration. 
In addition to offering stormwater source control benefits, bioretention cells also offers aesthetic benefits as they are often designed as a part of landscape feature. However, bioretention cells are landscape features and will require surface space to apply. Bioretention cells for road runoff control will require the presence of green strips running lengthwise adjacent to the roadway. In a densely developed city such as Toronto, very little space within the municipal right-of-way is available for the implementation of bioretention cells.

One possible solution to overcome this problem is to adopt soil cells as an underground bioretention device (Page et al. 2015).

Soil cells are plastic structural grid systems used to support pavement to create a void underneath, the void is backfilled with uncompacted soil to host trees as shown in Figure 3. Stormwater can be directed by irrigation into the soil cell. Page et al. suggests the treatment process in the soil cell would be analogous to bioretention cells.

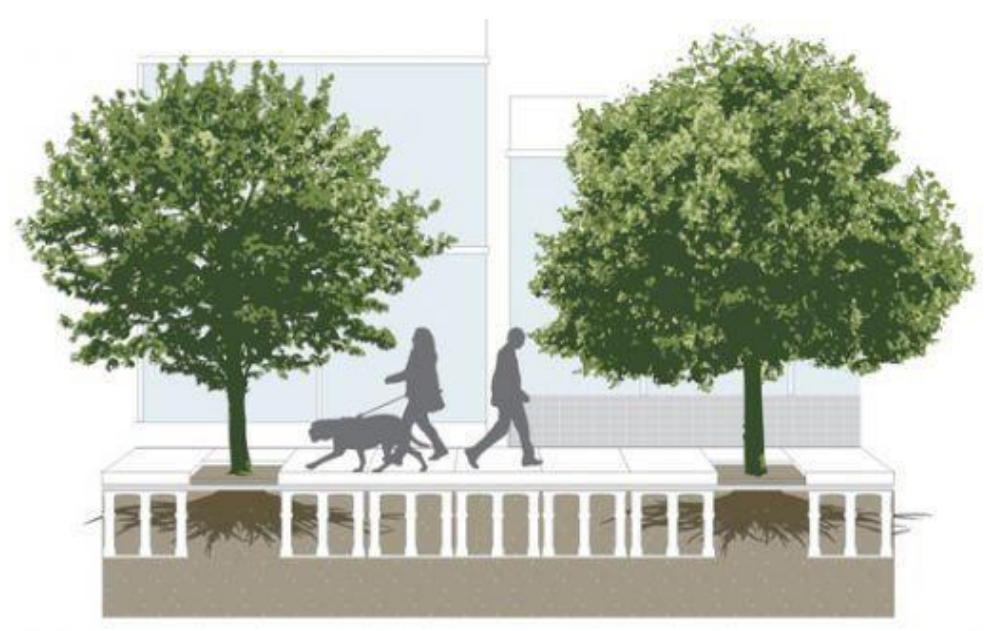

Figure 3. Soil Cell (Marritz, 2016)

Studies on the health of trees in soil cells have been conducted in South Asia (Ow and Ghosh 2017a; b) and in North America However (Ordóñez-Barona et al. 2018), due to the novel nature 
of soil cell as a stormwater control device, there is a lack of literature on the soil cell's hydraulic and treatment performance. Therefore, its effectiveness in stormwater quality is not well understood.

Perforated pipe is a component of soil cell as LID devices, and it can be placed at the top of the soil medium, just below the pavement. They are used to exfiltrate stormwater into the soil, and this is a novel application of perforated pipes. To achieve the efficient use of the soil cell, the perforated pipe should be designed in a way such that the water is exfiltrated at an even rate along the pipe. There is currently a lack of guidance regarding the selection of a pipe of the appropriate size and perforations.

Previous research (Bandehali 2015) has identified the potential backwater effect in the perforated distribution pipe resulting from inflow rate exceeding the exfiltration capacity of perforated pipe. Therefore the exfiltration rate of perforated pipes.

\subsection{Problem Statement}

The performance of individual bioretention cells has been studied and replicated many times across the world, both in real-world implementation and laboratory environment monitoring by multiple researchers and agencies (Davis et al. 2001; He and Davis 2011; Hsieh and Davis 2005; Khan et al. 2012a; b; Van Seters 2008, 2014).

The accumulated body of knowledge of bioretention cell systems has guided the development of multiple design guidelines by multiple agencies with modified designs that have been developed to suit different geographic conditions and local characteristics. Some of these designs also have been engineered to target specific pollutants of concern. 
There is a large gap between the state of knowledge of bioretention and soil cell. There is currently an insufficient amount of literature published on the performance of soil cells, resulting in lack of understanding of how soil cells functions.

Despite the similarity between soil cell and bioretention, there are several differences between them. One is that the soil cell is buried underground and is not open to the atmosphere. This could affect the air composition within the cell which could have an impact on the microbial community. The pavement placed on top of the cell could also form an insulation layer, preventing the cell from freezing in winter.

It is unknown how will these differences will impact soil cells differently when compared to bioretention, and whether the literature on bioretention can apply to soil cell. Therefore monitoring of a soil cell can further contribute to the body of knowledge on the novel LID device.

Another significant difference between traditional bioretention cells and soil cells is the way how the runoff is distributed. Bioretention typically have a ponding area such that the entirety the cell is used for filtration, therefore maximize the efficiency of the system. In contrast to bioretentions systems, soil cells do not have a ponding area but rather uses perforated pipe to distribute flow into the soil medium. Therefore, to achieve maximum utilization of the soil in the cell, even exfiltration out of the perforated pipe is required. As perforated pipes are traditionally used for drainage purposes, the exfiltration performance of perforated pipes is not well understood. Hydraulic modelling of a perforated pipe can aid in the design of an efficient soil system. 


\subsection{Objectives and Scope}

\subsubsection{Objective and Scope}

The objectives of the thesis is to gain further understanding of the hydraulic and treatment performance of soil cell in its new role as a LID practice and to enhance knowledge for the design of the perforated pipe distribution system in future implementations of soil cells.

The first objective will be accomplished through the monitoring of a real-world implementation of a soil cell in City of Toronto from 2016 to 2017. The treatment performance of the soil cell and concentration for key pollutants were obtained through sampling and testing of influent and effluent sample. The hydraulic performance was monitored using real-time monitoring methods. The data were statistically analyzed to draw informed conclusion.

The second objective is to study the hydraulic performance of perforated pipes via physical model to further understand whether even distribution of water is achieved and to measure exfiltration rate. This information will assist in the development of a design guideline for soil cells.

\section{Literature Review}

The literature review is broken down into two sections. The first part will focus on literature relating to bioretention cells as a stormwater control device. The second part focuses on the performance of perforated pipe as an exfiltration device. 


\subsection{Performance and Design of Bioretention Cells}

Due to the recent application of road side soil cells, there is currently a lack of literature regarding the evaluation of their performance However, as traditional bioretention cells share a similar treatment process with soil cells, the literature review focuses on will investigate the design, monitoring, and function of traditional bioretention cells which may be similar to road side soil cells.

\subsubsection{Bioretention Design}

Since its introduction, bioretention cell designs have evolved to specialize in addressing challenges encountered in the field. Minnesota Stormwater Manual (Minnesota Pollution Control Agency, 2018) describes the following four types of bioretention facility and their applicability:

Infiltration / Recharge Facility: This type of facility is suitable for native soil with high drainage coefficient and where infiltration would not contaminate groundwater. The design of infiltration/recharge facility is simply an excavated depression, backfilling with engineered soil and topped with vegetation. A typical cross-section of this facility is shown in Figure 4. 


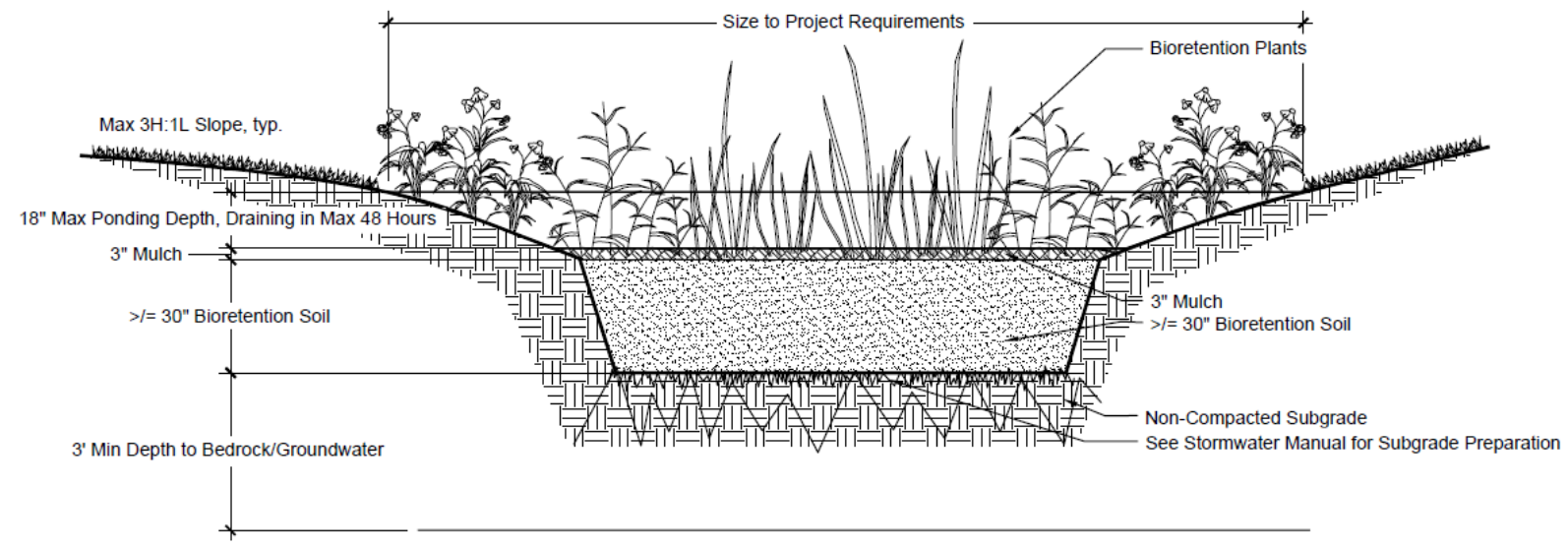

Figure 4. Typical Infiltration / Recharge Bioretention Cell Cross Section (Minnesota Pollution Control Agency, 2018)

Filtration / Partial Recharge Facility: This type of facility is designed for situations where low permeability native soil exists, thereby offering poor drainage and are likely to cause excessive surface poding. Filtration / partial recharge is suitable in these cases to receive runoff contaminated with nutrients and metal. The design of filtration / partial recharge facility consists of a filtration layer comprised of engineered soil, a drainage layer comprised of gravel and an underdrain to prevent excessive ponding as illustrated in Figure 5.

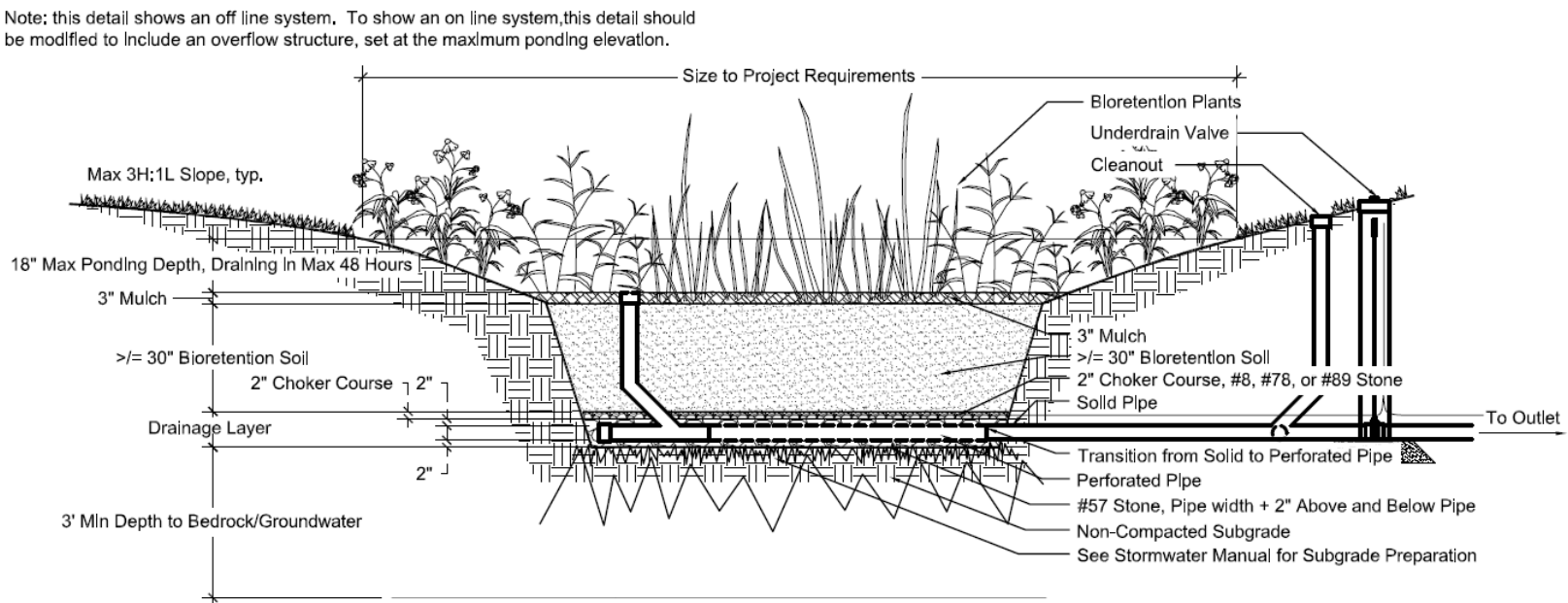




\section{Figure 5. Typical Filtration / Partial Recharge Bioretention Cell Cross Section}

(Minnesota Pollution Control Agency, 2018)

Infiltration / Filtration / Recharge: This type of facility is suitable for sites where high nitrate loading is expected This facility is designed to have a fluctuating saturation zone to promote denitrification for enhanced nitrate treatment. The design of this type of facility consists of a thick drainage layer where the underdrain is placed at the top of the drainage layer to retain water in the lower layer, as the retained water is evapotraspirated during the try weather, the water level is allowed to fluctuate. Figure 6 shows a typical cross-section.

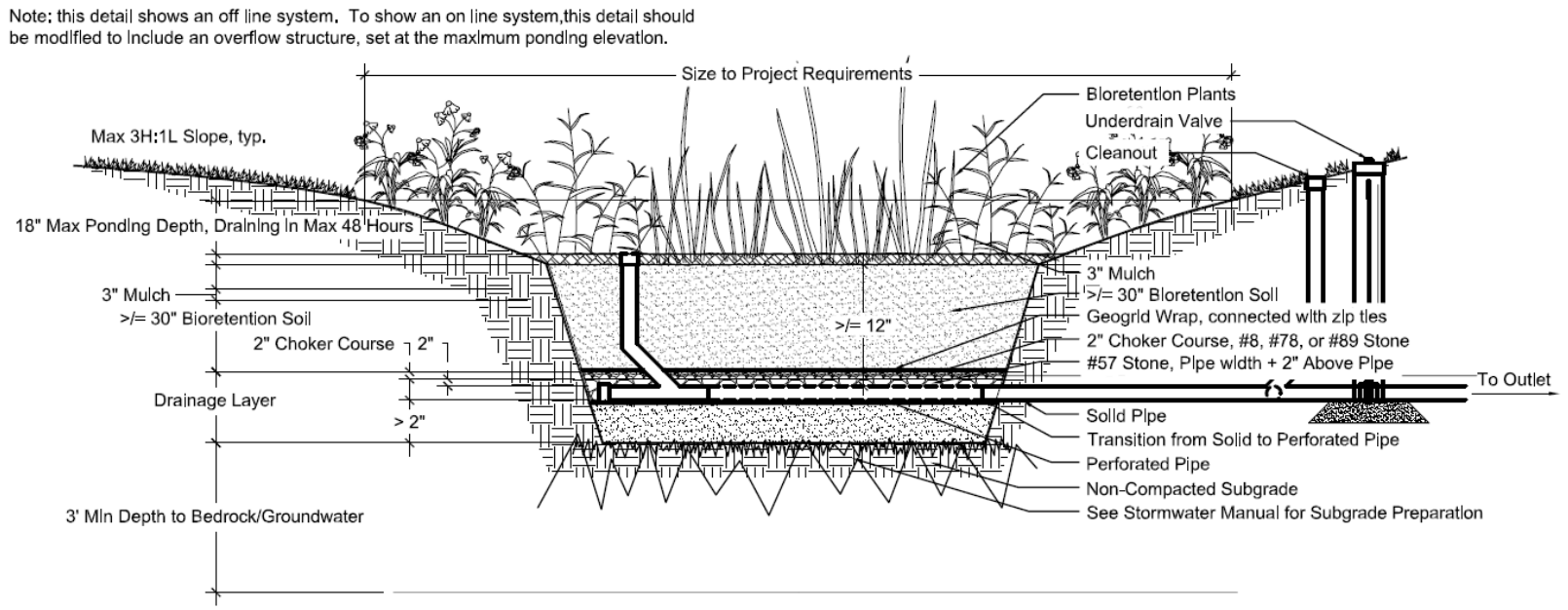

Figure 6. Typical Infiltration / Filtration / Recharge Bioretention Cell Cross Section (Minnesota Pollution Control Agency, 2018)

Filtration Only: This type of bioretention cell is typically used for pollution hotspots such as transportation depots, where infiltration could cause soil and groundwater contamination. The design for this type of bioretention cell is similar to the filtration / partial recharge facility. The difference is that the entire bioretention facility is enclosed in a impermeable liner such that the infiltration into the native soil is inhibited. The 
filtered runoff is discharge via the underdrain. The typical design for filtration facility is illustrated in Figure 7.

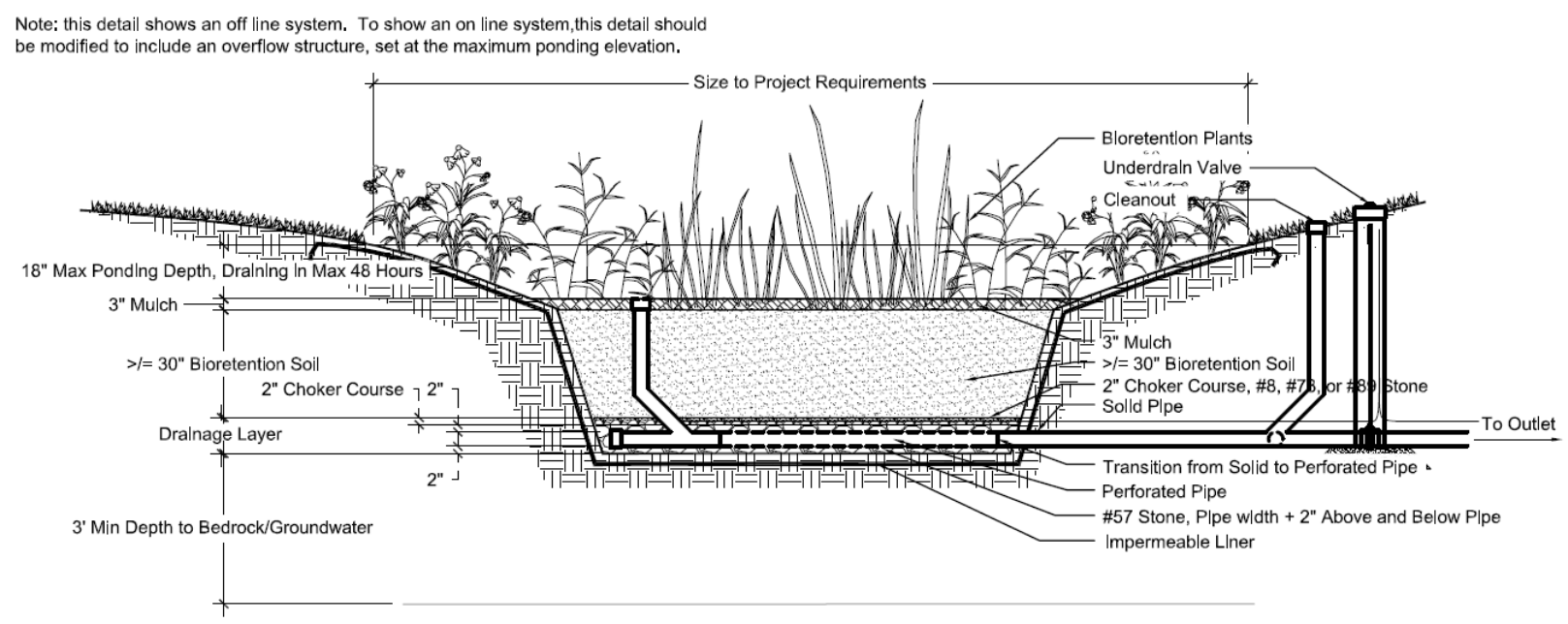

Figure 7. Typical Filtration Only Bioretention Cell Cross Section (Minnesota Pollution Control Agency 2018)

The performance of bioretention facility is measured by its ability to offer water quality improvement and water quantity control.

Another important aspect of bioretention cell design is the sizing. Roy-Poirier et al. identified the following five approaches (Roy-Poirier et al. 2010):

1. Runoff volume-based design: This approach is adopted by relevant agencies in Vermont and New York. New York state requires that the pore space and ponding volume to be greater than the predetermined treatment volume (Center for Watershed Protection and New York State Department of Environmental Conservation 2015). Vermont on the other hand requires that the treatment volume to be filtered through the soil over a recommended period of two days (Vermont Agency of Natural Resources 2017). 
2. Percentage of the impervious area: Idaho Department of Environmental Quality suggests the bioretention size should occupy 5-7\% of the drainage area (Idaho Department of Environmental Quality 2005).

3. Loading rate-based design: Delaware specifies if a bioretention facility were to receive 18 inches of loading over 48 hours, a maximum runoff of 1 inch should be given. The guideline suggests a properly designed facility should occupy $5-7 \%$ of the impervious area in a development, the same percentage as Idaho (Lucas 2004).

4. Model based sizing design: RECARGA modelling software was still recommended in the latest edition of their technical manual. (Kucher and Loowndes 2014)

The composition of backfill material generally consists of mostly sand, some clay and a small percentage of organic materials. The exact makeup can vary, for an example New York State suggests $50-70 \%$ of sand with 5\% or less clay, and 50\%-30\% topsoil with 5\% organics (Center for Watershed Protection and New York State Department of Environmental Conservation 2015). Meanwhile North Carolina suggests $75-85 \%$ medium to coarse sand, $8-10 \%$ fines and 510\% of organics (North Carolina Department of Environmental Quality 2017).

The only design guideline available for soil cells is published by the North Carolina Department of Environmental Quality (NCDEQ), and it largely resembles the design guideline for bioretention in terms of sizing and backfill specification. The current sizing criterion adopted by NCDEQ is runoff volume-based, which requires the ponding and void volume to be greater or equal to the control volume, which is the same criterion for bioretention cell sizing adopted by New York State and NCDEQ in their latest guideline as per discussion above. NCDEQ recommends that the internal water storage (IWS) accomplished through an upturned elbow. In 
a sense, NCDEQ recommends all soil cells to be implemented as Infiltration / Filtration /

Recharge facilities for enhanced nitrate treatment(North Carolina Department of Environmental Quality 2017).

\subsubsection{Performance Monitoring}

There are two common targets for any monitoring program, water quality and water quantity.

\section{Water Quality}

One important criterion for measuring stormwater quality control performance of bioretention cells is the concentration removal of pollutants calculated with Equation 1 below (Khan et al. 2012b).

$$
\Delta C_{\%}=\frac{C_{\text {in }}-C_{\text {out }}}{C_{\text {in }}} \times 100 \% \quad \text { Equation } 1
$$

Where

$\Delta C_{\%}$ is the concentration reduction in percent

$C_{\text {in }}$ is the influent concentration

$C_{\text {out }}$ is the effluent concentration

As the accumulated pollutants on urban surfaces are washed off during the early period of storm events, the pollutant concentration is higher in the beginning and lower afterward. Therefore, the concentration of contaminants can vary significantly over the course of a storm event. One individual concentration is typically not representative of a runoff event. The average 
concentration is typically reported as Event Mean Concentration (EMC) expressed by Equation 2 below:

Where

$$
E M C=\frac{\text { Mass }}{\text { Volume }}=\int_{0}^{T_{d}} \frac{C_{t} Q_{t} d t}{Q_{t} d t}
$$

$T_{d}$ is the duration of the event

$C_{t}$ is the concentration of the sample at time $\mathrm{t}$

$Q_{t}$ is the flow rate at time $\mathrm{t}$

Though it is feasible to measure the concentration of certain pollutants such as chloride and dissolved oxygen in real-time and will product an accurate EMC, the continuous real-time monitoring solution for a broad spectrum of pollutants does not exist currently. Composite samples are often used as a surrogate for EMC. California Department of Transportation's Stormwater Monitoring Guidance Manual (Caltran) discussed two general approaches to collect composite samples, based on aliquot samples collected by automatic samplers (California Department of Transportation 2015):

Time-Portioned Composite Sampling: Time-proportioned composite sample is comprised of aliquot samples of equal volumes taken at specified time intervals. As pointed out by Caltran, this technique disregards the change in flow volume (California Department of Transportation 2015).

Flow-Portioned Composite Sampling: Flow-portioned composite sample are comprised of aliquot samples taken at specified intervals of flow volume; this technique produces a better representation of EMC as it accounts for the varying flow rate over the course of a storm event (California Department of Transportation 2015). 
Caltran recommends the samples to be refrigerated until analyzed (California Department of Transportation 2015).

\section{Water Balance Monitoring}

To mimic the pre-development flow condition, bioretention cells must be able to reduce the peak flow rate, flow volume and delay peak, and these three criteria are the typical measure of a bioretention cell system's water quantity control performance.

The volume reduction can be expressed with Equation 3 below:

Where

$$
\Delta Q_{\%}=\frac{Q_{\text {in }}-Q_{\text {out }}}{Q_{\text {in }}} \times 100 \% \quad \text { Equation } 3
$$

$\Delta Q$ is the flow reduction in percentage

$Q_{\text {in }}$ is the total inflow volume

$Q_{\text {out }}$ is the total outflow volume

Peak reduction can be calculated similarly using Equation 4 below

Where

$$
\Delta Q_{\text {pea }_{\%}}=\frac{Q_{\text {peak }_{\text {in }}}-Q_{\text {peak }} \text { out }_{\text {of }}}{Q_{\text {peak }}} \times 100 \% \quad \quad \text { Equation } 4
$$

$\Delta \mathrm{Q}_{\text {peak\% }}$ is the peak flow reduction in percentage

$\mathrm{Q}_{\text {peak }_{\text {in }}}$ is the peak inflow rate

$\mathrm{Q}_{\text {peak }_{\text {out }}}$ is the peak outflow rate

Peak delay is simply the lag time between the peak flow at the inflow and the peak of outflow as shown in Figure 8 below: 


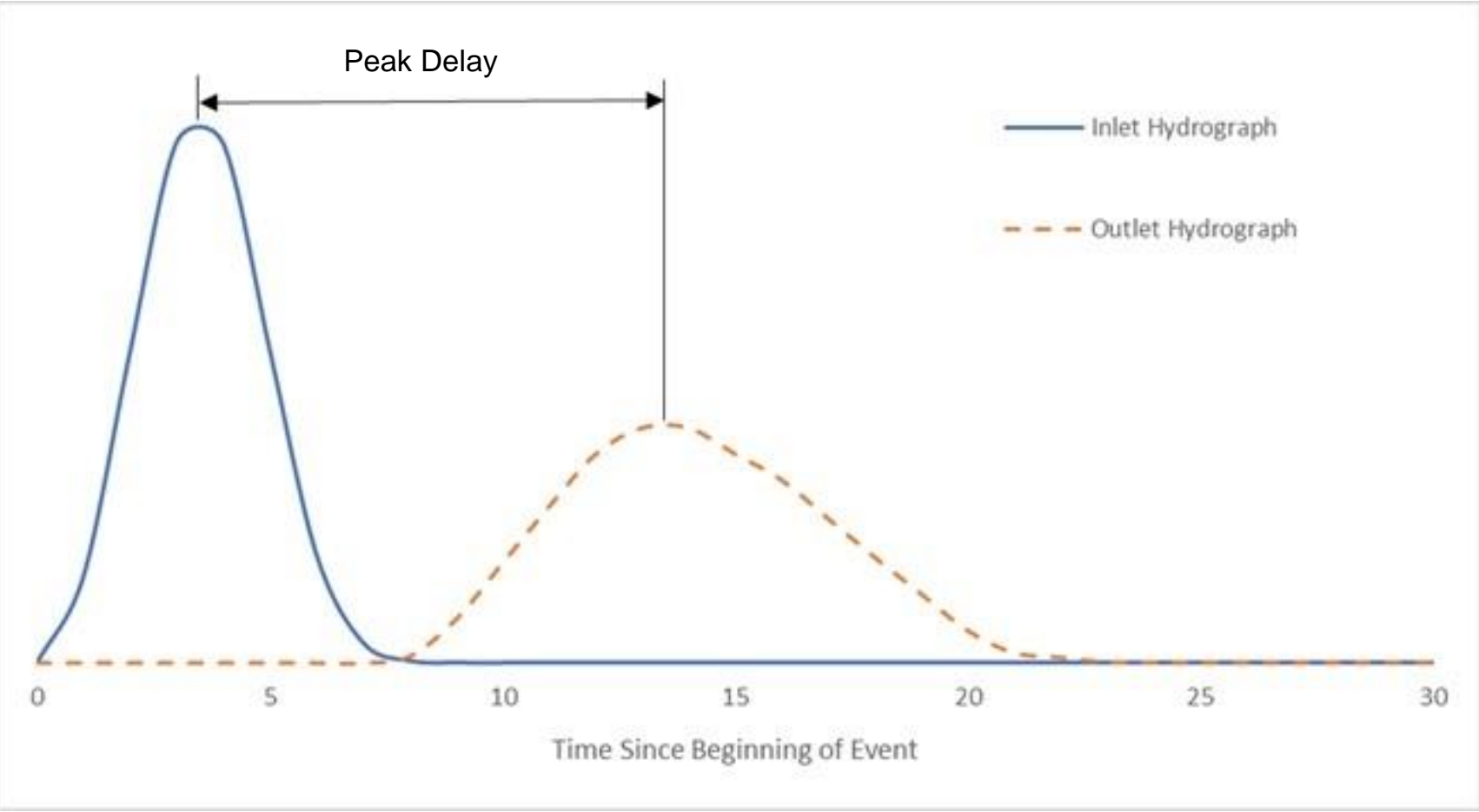

Figure 8. Peak Delay

Continuous flow rate monitoring is required for the calculation of above three parameters, which can be achieved using combination of weirs and flumes and automatic water level measurement. Weirs and flumes are devices typically used in flow rate measurement. Based on the flow is directed through a notch in the case of a weir, or a channel in the case of a flume, the relationship between flow depth and flow rate is calibrated by the manufacturer and this relationship is provided in a table or equation. Caltran's Stormwater Monitoring Guidance Manual suggests a real-time monitoring of water level could be obtained using bubblers or transducers connected to an automatic digital logger. Weirs provides a simple method for flow rate measurement as only flow depth measurement needs to be taken. One assumption for proper usage of weirs it that the side facing downstream must be freed of obstruction. The flow must come out of the weir notch 
unimpeded for proper functionality. Figure 9 illustrates the condition for the correct and incorrect operating condition for weirs.

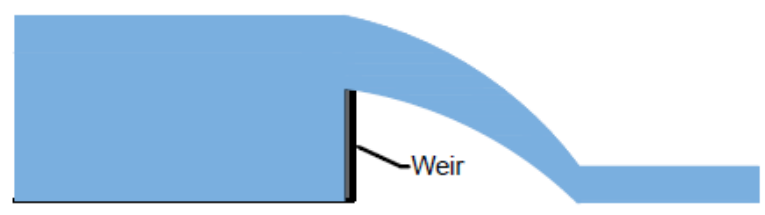

Correct - Downstream is free-flowing

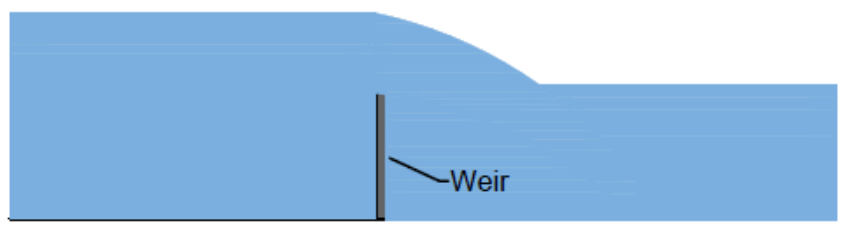

Incorrect - Weir is submerged

Figure 9. Weir Operating Conditions

\subsubsection{Source of Pollutants in Stormwater}

Stormwater runoff from road surfaces carries the accumulated pollutants during dry weather resulting from vehicle operations. It is now widely recognized as a nonpoint source of pollution by multiple associated agencies such as the United States Environmental Protection Agency (US EPA, 2015). Numerous studies have been conducted on the composition of the pollutants runoff and its transportation mechanism (Aryal et al. 2010; Kratky et al. 2017).

A general overview of sources of pollutants found in road runoff is presented in Figure 10. 


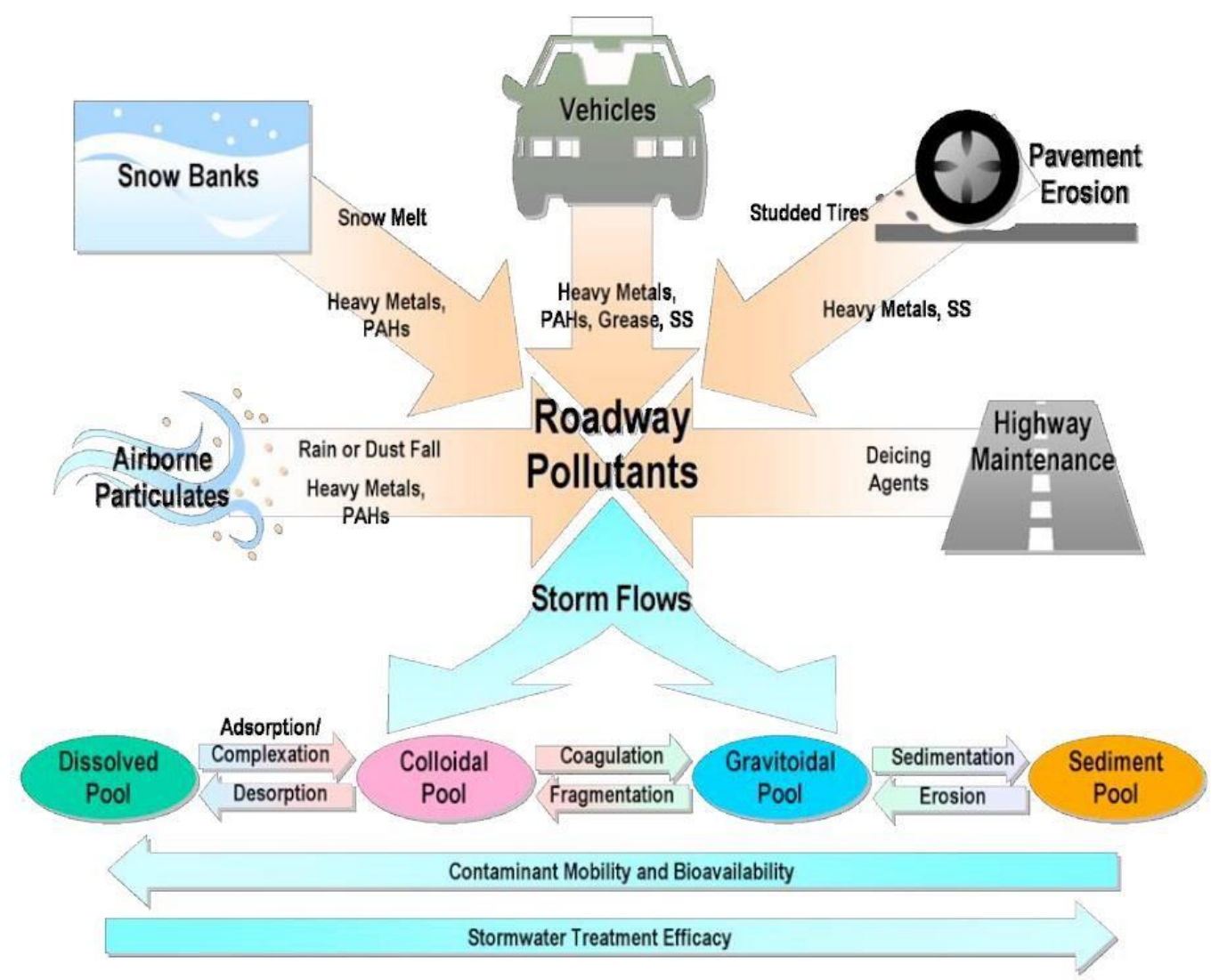

Figure 10. Mechanisms of Pollutant Accumulation on Roads (Grant et al. 2003)

Aryal et al. conducted a thorough meta-analysis of literatures on urban stormwater pollutants and identified the following pollutants as commonly found in road runoff.

\section{$\underline{\text { Particulates }}$}

Particulate matters are also known as Total Suspended Solids (TSS). Their accumulation on road surfaces are results of vehicle operations namely braking, tire abrasion and exhaust, and other factors such as road surface erosion. Building erosion and soil particles eroded by wind can also be deposited on the road surface (Aryal et al. 2010). Particulates are accumulated on the road surface during dry weather and are washed off during storm events. Eventually they are deposited in the aquatic environment. 
TSS are typically exhibit strong correlation with other types of pollutants including metal, hydrocarbons, and organics (Aryal et al. 2010). A meta-analysis conducted by Aryal et al. found that a finer particle content is associated with a disproportionately high percentage of all pollutants; examples cited in Aryal et al.'s study shows fine particulates frequently make up of less than $10 \%$ of TSS by volume but contribute over $50 \%$ of various types of pollutants (Aryal et al. 2010).

Loganathan et al. suggests the accumulation pattern of particulates on roads can be influenced by various factors such as pavement material, traffic volume, composition of traffic by vehicle type (e.g. truck vs cars) and speed limit (Loganathan et al. 2013); Though considerable literature is available on the subject of Particle Size Distribution (PSD) at specific sites, no widely adopted generalized model for PSD distribution suitable for all sites exists in literature.

Aryal et al concluded a variety of factors can influence the wash-off pattern, such as rain intensity and duration, PSD and seasonal factors (Aryal et al. 2010). The interaction between these factors are poorly understood and no generally accepted model was located.

A long-term study conducted by the U.S Geological Service in cooperation with Wisconsin Department of Natural Resources demonstrated that PSD in stormwater runoff can vary significantly even at a single location. The study monitored three road sections of different categories: Feeder Street, Collector Street, and Arterial Street in Wisconsin over a period of at least 21 events (Selbig and Bannerman 2011). The study demonstrates the coefficient of variation of fine particles composition, defined as particles of less than 
$63 \mu \mathrm{m}$ in this case, is at least 0.5 . The statistical summary of fine particle composition from the study is shown in Table 1.

Table 1. Composite of 63um Particles by Mass in Wisconsin (Adapted Selbig \& Bannerman, 2011)

\begin{tabular}{|c|c|c|c|c|}
\cline { 3 - 5 } \multicolumn{2}{c|}{} & \multicolumn{3}{c|}{ Content Particles of 63 $\boldsymbol{\mu m}$ or Finer } \\
\hline Road Type & $\begin{array}{c}\text { \# of Observed } \\
\text { Events }\end{array}$ & Mean (\%) & $\begin{array}{c}\text { Standard } \\
\text { Deviation }(\boldsymbol{\%})\end{array}$ & $\begin{array}{c}\text { Coefficient of } \\
\text { Variation }\end{array}$ \\
\hline Collector Street & 21 & 48 & 26 & 0.54 \\
\hline Feeder Street & 21 & 28 & 20 & 0.71 \\
\hline Arterial Street & 48 & 39 & 25 & 0.64 \\
\hline
\end{tabular}

TSS concentration reduction to mechanical filtration process and sedimentation, the TSS removal performance tends to improve over the life of a bioretention cell system as the finer pores are clogged (Kratky et al. 2017). TSS concentration reduction can suffer from cold weather conditions as cold water temperature can affect the settling velocity of particulates (Roseen et al. 2009).

As infiltration allows the contaminated stormwater to return to groundwater, this mechanism contributes to the mass reduction of TSS, as well as other pollutants. Due to high infiltration capacity of a well-designed system in cold weather condition, the TSS mass reduction performance remains high in cold weather condition despite lower concentration reduction efficiency. One interesting observation made by Khan et al. is the depth of soil medium do not have an impact on TSS concentration reduction efficiency (Khan et al. 2012b). 


\section{$\underline{\text { Nutrients }}$}

Though nutrients are essential in the ecosystem, excess nutrients in an aquatic system can cause eutrophication. The two major nutrients of concern are phosphorus and nitrogen; the two pollutants exhibit drastically different characteristics in stormwater. Yang and Toor attribute the source of nitrogen in urban runoff to the accumulation and decay of biological material such as leaves and animal dropping on roofs and roads. In addition, anthropogenic sources such as fertilizer used in lawn care could also be considered as a source depending on the local conditions (Yang and Toor 2017). Nitrogen can take on various forms including ammonium $\left(\mathrm{NH}^{4+}\right)$, nitrous oxide (NO), nitrate $\left(\mathrm{NO}_{3}{ }^{-}\right)$. A significant variation in the dissolvable portion of Nitrogen has been reported in numerous studies. The dissolvable portion percentage is reported as high as 90\% (Wu et al. 2015) to 80\% (Miguntanna et al. 2013), while other studies have shown the dissolvable portion to only account for $20 \%$ to $50 \%$ (Aryal et al. 2010). The discrepancy is noted by in other studies as well (Wu et al. 2015). Aryal et al. identified nitrate as a species of major concern due to its potential for soil contamination. Typical bioretention cells have generally performed poorly in nitrate removal; in fact nitrate leaching is a common occurrence in bioretention cells. Nitrate concentrations were observed to increase by $64 \%$ to reduction of $19 \%$ in laboratory condition (Hsieh and Davis 2005), the formation of nitrate can be attribute to the conversion from Organic Nitrogen and Total Ammoniacal Nitrogen during the aerobic condition of dry weather and flushed out during rain events (Kim et al. 2003). 
Studies agree that phosphorus is much less dissolvable than nitrate. The insoluble portion of total phosphorus accounts for $84.6 \%$ for the road as reported (Wu et al. 2015) and $60 \%$ to $85 \%$ (Aryal et al. 2010).

A meta-analysis conducted by Kratky et al., attributes phosphorus removal to absorption by soil medium and filtration when phosphorus exists mainly as particulates. High phosphorus content in soil medium can impede the soil absorption of phosphorus and facilitates the conversion of an insoluble form of phosphorus into the soluble orthophosphorus resulting in leaching (Kratky et al. 2017)

\section{$\underline{\text { Metals }}$}

Metals are pollutants of concern due to their toxicity and persistence (Aryal et al. 2010). Vehicle traffic is generally recognized as the source of metal pollutants; brake dust, tire abrasion and rust on vehicles emit metal particles (Loganathan et al. 2013).

The relationship between traffic and pollutant accumulation is not well understood as most of the studies reviewed for the thesis focused on the metal concentration of runoff rather than the characteristics of accumulation as a function of vehicle traffic. A metaanalysis by Loganathan et al. demonstrates the variety of factors including road surface type, speed limit, traffic type and past leaded gasoline use can influence the pattern of metal accumulation (Loganathan et al. 2013).

Kratky et al concludes that particulate metal can be removed through a simple filtration process, and the exact mechanisms for the removal of dissolved metal are not wellunderstood (Kratky et al. 2017). Studies conducted by Dean et al. have suggested that 
factors such as cation exchange, adsorption, precipitation, and complexation can contribute to the reduction of dissolved metals (Dean et al. 2005). Kratky et al suggests that organic content in soil medium is mostly responsible for removal of dissolved metal; a mere $5 \mathrm{~cm}$ layer of mulch can effectively control metal in stormwater (Kratky et al. 2017). Literature regarding the effects of cold weather on metal concentration have yielded inconsistent results; decreased performance for zinc, increased performance for copper and leaching of all metal have all been observed (Kratky et al. 2017). Hence no conclusive study on this subject was located.

\section{$\underline{\text { Salts }}$}

Road salt is used to melt ice and snow in climates with cold winters. Sodium chloride $(\mathrm{NaCl})$ is the most typical de-icing salt used in Canada (Kratky et al. 2017), and it dissociates into ions $\left(\mathrm{Na}^{+}\right.$and $\left.\mathrm{Cl}^{-}\right)$in solution. It is considered a highly soluble and conservative substance that cannot be removed by biological process or filtration. Through literature review, Green et al. concludes that salt in a soil can have a detrimental effect on plant life; plants can suffer from leaf scorching, wilting and slow growth (Green et al. 2008). Chloride in the aquatic environment can reduce diversity by reducing survivability of salt-sensitive species such as tadpoles and certain fishes (Novotny and Stefan 2010). In addition to its detrimental impacts, salt is known to increase the mobility of pollutants such as heavy metal (Green et al. 2008).

Salt concentration is a function of the amount of salt applied to roads and sidewalks by municipalities and private property owners. Salt is considered a very soluble and conservative substance and no current technology is capable of significantly reducing its 
concentration. Mass reduction is attributed to infiltration into the ground water rather than retention of salt in the soil medium; however certain jurisdictions do not allow the infiltration of stormwater contaminated with salt in order to protect groundwater (Minnesota Pollution Control Agency 2018) (Hill 2018).

\section{Organics}

Anthropogenic sources of organic contaminants on road surfaces are typically related to vehicle traffic, incomplete combustions and leaking of lubricant, wear and tear of tires, car paint can leave a wide range of hydrocarbons on the road surface, even the erosion of asphalt road surface can contribute to organics loading(Aryal et al. 2010; Markiewicz et al. 2017). Natural sources of organics can include dead plant materials, fecal coliforms deposited by animals.

Some organic materials can be consumed by microbials in aerobic digestion process, excessive loading of organics can lower dissolved oxygen (DO) in natural bodies of water. Biochemical Oxygen Demand (BOD) is a measure of the concentration of the bioavailable organics.

The concentration of anthropogenic organics is a function of multiple factors including speed limit, traffic patterns, vehicle composition of traffic and general condition of vehicles that uses the road(Markiewicz et al. 2017). The composition and concentration of anthropogenic can vary greatly (Aryal et al. 2010).

In conclusion, the literature suggests that the concentration of pollutants can vary greatly depending on a multitude of factors and cannot be accurately predicted; therefore, monitoring is required to assess the performance of a LID system. The major pollutants in an urban 
environment such as Toronto are identified through literature review, which are particulate matter, metal, nutrients including phosphorus and nitrate, chloride and organics. The concentration for these pollutants will be the focus of water quality parameters.

\subsubsection{Performance of Bioretention}

As mentioned in Section 2.1.2, the performance of bioretention cells can be evaluated based on its water quality and water balance performances.

\section{$\underline{\text { Water Quality }}$}

International Stormwater Best Management Practices Database is a collaborative effort by several agencies including United States Environmental Protection Agency, American Society of Civil Engineers, and the United States Department of Transportation among others. The database contains an aggregation of the water quality results obtained from the monitoring of over 700 LID practices. The statistical summary of water quality data for bioretention cell systems is reported below in Table 2 .

As mentioned in 2.1.1 and 2.1.3, design parameters such as the backfill medium composition, age of the system, organic content of the soil and presence of a permanently saturated zone can be crucial for the performance of bioretention systems. While the database provides large volume of data on water quality, it should be noted the database is still an ongoing development and detailed design information on individual bioretention systems were not provided. 
Table 2. Summary for Stormwater Quality Treatment Performance of Bioretention Cells as per International Stormwater BMP

\begin{tabular}{|c|c|c|c|c|c|c|}
\hline \multirow[b]{2}{*}{ Pollutants } & \multicolumn{6}{|c|}{ Influent Concentration } \\
\hline & $\mathrm{n}$ & Q1 & Median & Q3 & Mean & $\sigma$ \\
\hline $\mathrm{Al}(\mu \mathrm{g} / \mathrm{L})$ & 10 & 283 & 398 & 619 & 681 & 856 \\
\hline $\mathrm{BOD}(\mathrm{mg} / \mathrm{L})$ & 37 & 4.6 & 6.0 & 8.6 & 10.2 & 12.1 \\
\hline $\mathrm{Cl}(\mathrm{mg} / \mathrm{L})$ & 362 & 3.0 & 7.0 & 17.0 & 46.0 & 169.0 \\
\hline $\mathrm{Cu}(\mu \mathrm{g} / \mathrm{L})$ & 466 & 6.3 & 13.0 & 29.8 & 145.0 & 431.0 \\
\hline $\begin{array}{c}\mathrm{Fe} \\
(\mu \mathrm{g} / \mathrm{L})\end{array}$ & 54 & 373 & 556 & 828 & 798 & 957 \\
\hline $\mathrm{Pb}$ & 263 & 2.7 & 6.2 & 17.8 & 17.1 & 67.0 \\
\hline $\begin{array}{c}\mathrm{Ni} \\
(\mu \mathrm{g} / \mathrm{L})\end{array}$ & 111 & 3.0 & 5.6 & 8.1 & 6.6 & 4.9 \\
\hline $\begin{array}{c}\mathrm{NO}_{3}^{-} \\
(\mathrm{mg} / \mathrm{L})\end{array}$ & 168 & 0.2 & 0.4 & 1.0 & 0.8 & 1.1 \\
\hline $\begin{array}{c}\mathrm{TP} \\
(\mathrm{mg} / \mathrm{L})\end{array}$ & 796 & 0.1 & 0.2 & 0.5 & 0.4 & 0.7 \\
\hline $\begin{array}{c}\text { TSS } \\
(\mathrm{mg} / \mathrm{L})\end{array}$ & 782 & 16.0 & 42.0 & 112.0 & 128.0 & 291.0 \\
\hline $\begin{array}{c}\mathrm{Zn} \\
(\mu \mathrm{g} / \mathrm{L})\end{array}$ & 454 & 28.5 & 58.6 & 137.0 & 113.0 & 180.0 \\
\hline
\end{tabular}

\begin{tabular}{|c|c|c|c|c|c|}
\hline \multicolumn{6}{|c|}{ Effluent Concentration } \\
\hline $\mathrm{n}$ & Q1 & Median & Q3 & Mean & $\sigma$ \\
\hline 32 & 89 & 158 & 448 & 271 & 231 \\
\hline 32 & 2.9 & 4.6 & 8.0 & 8.3 & 11.4 \\
\hline 268 & 3.8 & 10.0 & 36.3 & 50.6 & 134.0 \\
\hline 438 & 4.2 & 7.2 & 14.8 & 17.1 & 27.2 \\
\hline 74 & 200 & 595 & 1400 & 1590 & 2920 \\
\hline 251 & 0.3 & 1.5 & 4.3 & 3.9 & 7.4 \\
\hline 120 & 1.9 & 3.0 & 4.7 & 5.1 & 7.1 \\
\hline 94 & 0.3 & 0.6 & 1.0 & 0.8 & 0.9 \\
\hline 632 & 0.1 & 0.2 & 0.6 & 0.5 & 1.4 \\
\hline 651 & 5.0 & 11.0 & 21.0 & 20.4 & 38.9 \\
\hline 432 & 7.7 & 13.9 & 24.0 & 21.4 & 28.3 \\
\hline
\end{tabular}

\begin{tabular}{|c|c|}
\hline $\begin{array}{c}\text { Median Con } \\
\text { Reduction }\end{array}$ & P-Value \\
\hline $60.3 \%$ & 0.496 \\
\hline $23.3 \%$ & 0.281 \\
\hline$-42.9 \%$ & 0.609 \\
\hline $44.6 \%$ & 0.000 \\
\hline$-7.0 \%$ & 0.0056 \\
\hline $75.8 \%$ & 0.0581 \\
\hline $46.4 \%$ & 0.0547 \\
\hline$-50.0 \%$ & 0.0829 \\
\hline $0.0 \%$ & 0.0022 \\
\hline $73.8 \%$ & 0.0000 \\
\hline $76.3 \%$ & 0.0000 \\
\hline
\end{tabular}

database

Note: $\mathrm{n}=$ number of samples, $\mathrm{Q} 1=$ first quartile, $\mathrm{Q} 3=3^{\text {rd }}$ Quartile, $\sigma=$ standard Deviation

Only composite samples are used in this table.

The location of bioretention cells practices are not provided in the database, therefore the source of influent is not necessarily road or even urban environment 
As shown on Table 2, all pollutants have shown large variation in influent and effluent concentration which is consistent with insight offered by 2.1.2. Traditional bioretention cells have demonstrated to be effective in removing TSS and some metal but ineffective in treating salt, phosphorus and in some cases have even caused leaching of nitrate.

\section{Water Balance}

As mentioned previously, bioretention cells' functions are two-fold; to control runoff quantity and improve water quality.

Bioretention cells have generally shown to have a good runoff control capacity. The mechanism contributing to quantity reduction is stored in the facility, infiltration into the native soil and evapotranspiration through plants.

Water is stored in the pores of the soil medium as moisture. Computational model (He and Davis 2011) has suggested that a finer soil medium may provide a better water storage capacity because of additional storage in the capillary space, while water stored in coarser grain, conversely, can drain out quickly.

Permeable native soil such as sand can accommodate a higher infiltration rate. Fields studies done in Toronto have shown high infiltration can be still achieved in native soils with poor drainage through selecting the correct soil medium (Van Seters 2014). Cold weather condition has not shown a significant impact on infiltration capacity was reported in multiple studies (Van Seters 2014; Minnesota Pollution Control Agency 2018; Davidson et al. 2008). Davidson et al. concludes as long as a system infiltrates properly in warm weather condition, the system will perform adequately in cold weather as well as the water will drain quickly and a ice-blanket will not form (Davidson et al. 2008). 
A wide range of evapotranspiration performance has been reported in the literature, from $3 \%$ reported in North Carolina (Brown and Hunt 2012) to 9.26\% reported in Toronto (Van Seters 2014). Kratky et al argues the variation is due to a range of factors including local climate, soil medium, and native soil characteristics (Kratky et al. 2017).

A long-term water balance study done in Toronto by Van Seters monitored a bioretention cell implemented at Living City Campus over two years between 2011 and 2012. The water balance result is reported in Table 3 below:

Table 3. Water Balance in Bioretention Cell at Living City Campus, Adapted from (Van Seters, 2014)

\begin{tabular}{|l|l|l|l|}
\cline { 2 - 4 } \multicolumn{1}{c|}{} & \multicolumn{3}{c|}{ Water Balance Component } \\
\hline Year & Infiltration(mm) & Evapotranspiration(mm) & Outflow $(\mathrm{mm})$ \\
\hline 2011 & 472 & 56 & 58 \\
\hline 2012 & 436 & 47 & 43 \\
\hline Total & 908 & 103 & 101 \\
\hline
\end{tabular}

Peak reduction and peak lag are two important parameters of bioretention hydraulic performance; these two parameters appear less frequently in literature.

Of the literature located, Barber et al. (Barber et al. 2003) reported 15 to 60 minutes of lag for a $1.2 \mathrm{~m}$ deep bioretention system with a peak reduction of 50-70\% under real-world conditions.

Davis shows the mean ratio of peak time at the outlet to peak at the inlet of a bioretention are 2 and 2.7 for a cell of $1.2 \mathrm{~m}$ and $0.9 \mathrm{~m}$ respectively (Davis 2008). Peak flow rates were reduced 6344\%. The mechanism responsible for peak reduction from both studies was identified as infiltration. 


\subsubsection{Conclusion for Literature on Bioretention}

The current development of bioretention cells are investigated in 2.1.1, the examination of specialized bioretention cells designs provided a cursory understanding of their performance expectation. The survey of sizing and soil medium guideline for soil cells and bioretention cells indicate the current state of practice is to adopt the same for both bioretention cells and soil cell, but a lack of study on the performance of soil cell prevents an assessment of the adequacy of the current state of design guidelines for soil cells.

With the understanding that soil cell and bioretention shares some similarity in terms of function and receiving water quality, section 2.1.2 forms a basis for an understanding of key performance monitoring criteria and methodology for bioretention cells. Concentration reduction is a key parameter of water quality control, peak delay, peak flow reduction and total volume reduction are key parameter of water balance performance. Continuous flow rate monitoring would be beneficial as it could enable flow-portioned water quality sample strategy (which would be the most accurate sampling methodology), while continuous monitoring is also required for the monitoring of water balance parameters.

Section 2.1.3 discussed water quality monitoring parameters in further detail, common pollutants of concern in an urban environment were identified and their sources and removal mechanism were discussed. The outcome of the section is to identify a focused list of pollutants which should be monitored during the operation, namely particulates, nutrients, metals and BOD. 
Section 2.1.4 overviewed the performance of traditional bioretention cells, which can vary greatly and consistent with literature reviewed in 2.1.3. The lack of good understanding of bioretention cells performance is identified by Cording et al. (Cording et al. 2017), whom recommends monitoring of local systems to assess their performance. The survey of published bioretention cells performance further bolsters the need of additional monitoring of LID system such as bioretention cells and soil cell in this case.

\subsection{Perforated Pipe}

Traditionally, a perforated pipe is typically used as an underdrain to remove excess water from the soil. Perforated pipes are finding new applications as the prevalence of LID increases. In its new role, perforated pipes are being used as conveyance and exfiltration devices. Majority of studies done on the hydraulic performance of perforated pipe have focused on its traditional function. An empirical study was conducted by Duchene and McBean on the exfiltration capacity of perforated pipes in gravel (Duchene \& McBean, 1992).

The experiment conducted by Duchene and McBean measured the total exfiltration rate under a constant upstream head with the apparatus illustrated in Figure 11. 


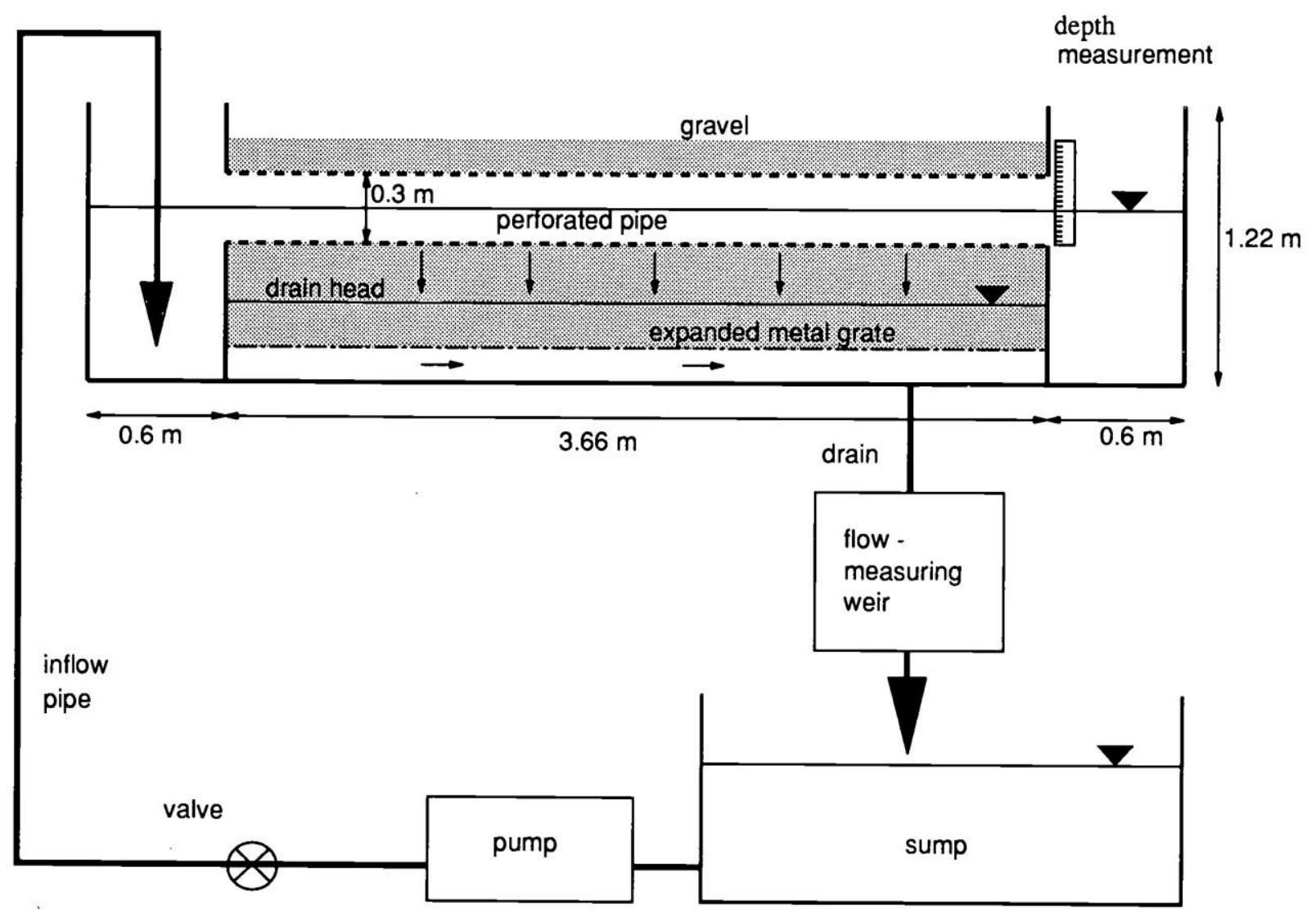

Figure 11. Experiment Apparatus Used by Duchene and McBean (Duchene \& McBean, 1992)

Two types of $300 \mathrm{~mm}$ diameter corrugated pipes were tested in the apparatus, one with a smooth inner wall and $12.7 \mathrm{~mm}$ circular perforation and another with corrugated wall and slit perforation. The details are shown in Figure 12.
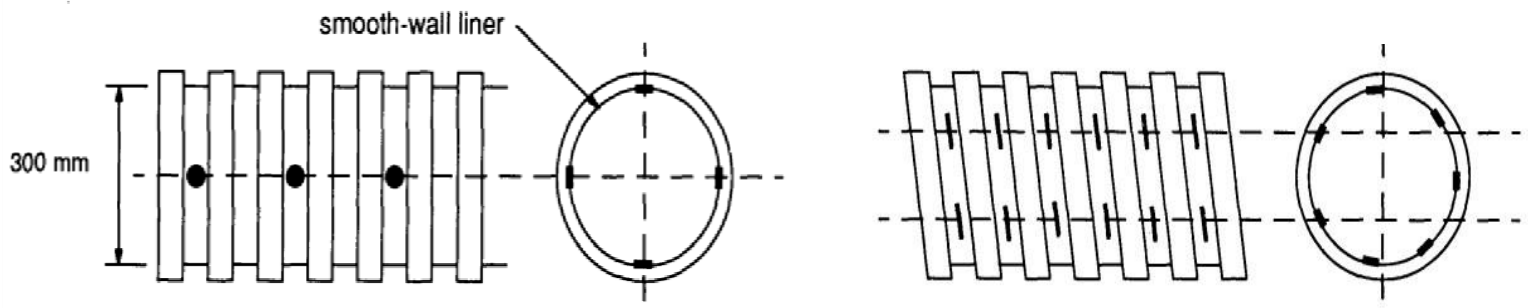

Figure 12. Profile and Cross Section of Perforated Pipes

(Duchene \& McBean, 1992) 
The experimental result from the smooth-wall pipe was used to calibrate the orifice coefficient using a modified orifice flow equation, which takes the height of the perforation into account, expressed in Equation 5 (Duchene \& McBean, 1992).

$$
Q=C_{d} A_{0} \sqrt{2 g}[\sqrt{D}+2 \sqrt{D-0.15}]
$$

Equation 5

Where

$\mathrm{Q}$ is the rate of discharge through the perforation

$\mathrm{C}_{\mathrm{d}}$ is the orifice coefficient, the unknown constant

$\mathrm{A}_{0}$ is the cross-sectional area of the perforation $\mathrm{g}$ is acceleration due to gravity

$\mathrm{D}$ is the diameter of the pipe

The orifice coefficient between three sets of tests with different angles of orifice

rotation ranges between $0.64-0.66$, with the value of $\mathrm{R}^{2}$ being between $0.88-0.95$.

The average orifice coefficient was 0.65 (Duchene \& McBean, 1992).

The second set of experiments were done on the slit perforated pipe (right image in Figure 11). Duchene and McBean were unable to measure the depth at each orifice, therefore the flow rate is expressed with an empirical equation as a function of the upstream head in Equation 6 (Duchene \& McBean, 1992).

$$
Q=13.2 \times H^{0.65}
$$

Equation 6

Since the publication of Duchene and McBean's paper, no further peer reviewed literature was located on the exfiltration capacity of perforated pipe for stormwater applications. 
Another application for the exfiltration of water through the perforated pipe is drip irrigation for agricultural purposes. The literature for this topic is commonly available, and models were developed by Qin et al. Through empirical testing and lab experiments, the current models in the literature take the velocity of exfiltrating water into account. (Qin, Liu, \& Wang, 2017), Lazrovitch et al constructed theoretical models for subsurface drip irrigation (Lazarovitch, Shani, Thompson, \& Warrick, 2006). It should be noted that drip irrigation aims for slow release of water rather than discharge it quickly as in soil cell, therefore perforations used in drip irrigation are much smaller in size in comparison to the ones used in stormwater and there were no examples of applying drip irrigation model to stormwater exfiltration found in literature. Therefore, the validity of these studies in stormwater is unknown. The two papers mentioned above are not reviewed in detail as numerical modelling for perforated pipe falls outside the scope of the thesis.

In conclusion, although there are some studies published on perforated pipes as exfiltration devices under certain specific conditions, these conditions may not apply to a stormwater application. McBean's research only studied the pipe's performance under a steady-state condition with a flat hydraulic gradient, in contrast to drip irrigation which occurs under a pressurized condition. Further studies may be needed to understand how perforated pipe performs hydraulically under stormwater condition. 


\section{Methodology}

As in the literature review, this section will also be divided into two parts. Section 3.1 will explain the methodology adopted for the monitoring of the soil cell and Section 3.2 will explain the lab experiment for measuring the hydraulic performance of the perforated pipe.

\subsection{Soil Cell Monitoring}

As previously stated in 1.3 .1 , the first objective of the thesis is to analyze the performance of the soil cell in terms of water quality treatment performance and water quantity control performance. Water quality performance is assessed through the collection and analysis of influent and effluent water samples, and water quantity performance is analyzed through the monitoring of the water level at weirs installed at inlet and outlet.

This section will describe the site which the monitoring operation was carried out, and the methodology adopted for the monitoring operation.

\subsubsection{Site Description}

The City of Toronto is located on the northern shore of Lake Ontario with warm and rainy summers of above $20^{\circ} \mathrm{C}$ and cold snowy winters of below $0^{\circ} \mathrm{C}$. Road salt is applied during the winter months after snowfall events. 
The soil cell is implemented in the Etobicoke District in the west end of Toronto, underneath the sidewalk and the off-street parking space along The Queensway between Moynes Ave and Berl Ave as shown in Figure 13.

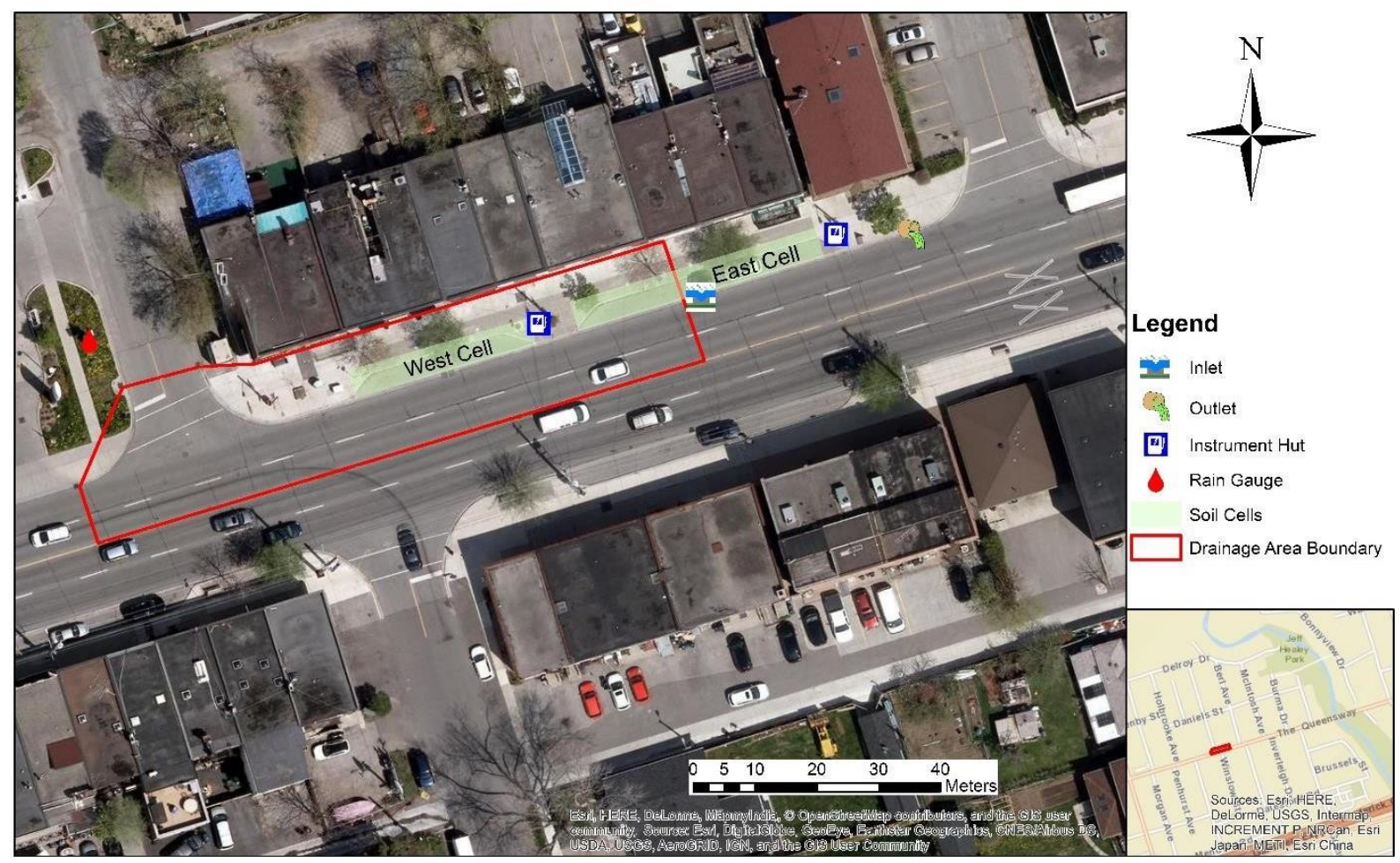

Figure 13. Layout of the Study Site

The soil cell receives runoff from a drainage area of $1074 \mathrm{~m}^{2}$ measured using aerial photo provided by City of Toronto, which mostly is comprised of a 76-meter stretch of the westbound two lanes of The Queensway. A small section of Moynes Ave of approximately 9 meters, and a residential street, also contributes to the drainage area. The stretch of the Queensway in the drainage area is considered a major arterial road by city of Toronto (City of Toronto, 2013), with speed limit of 50 kilometer per hour, and a road surface paved with asphalt. 
The terrain of the site shows an even slope down at a slight angle of $0.8 \%$ toward the east. Two soil cells were initially installed; the inlet grate of the West Cell was replaced with water-tight maintenance hole cover prior to 2016, thereby sealing it. The west cell was not monitored while the East Cell remains in operation.

\subsubsection{Design of the Soil Cell}

The soil cell receives runoff from the road via a drainage basin in front of 654 The Queensway as shown in Figure 14 via Google Street View. The inlet in the drainage basin is shown in Figure 15.

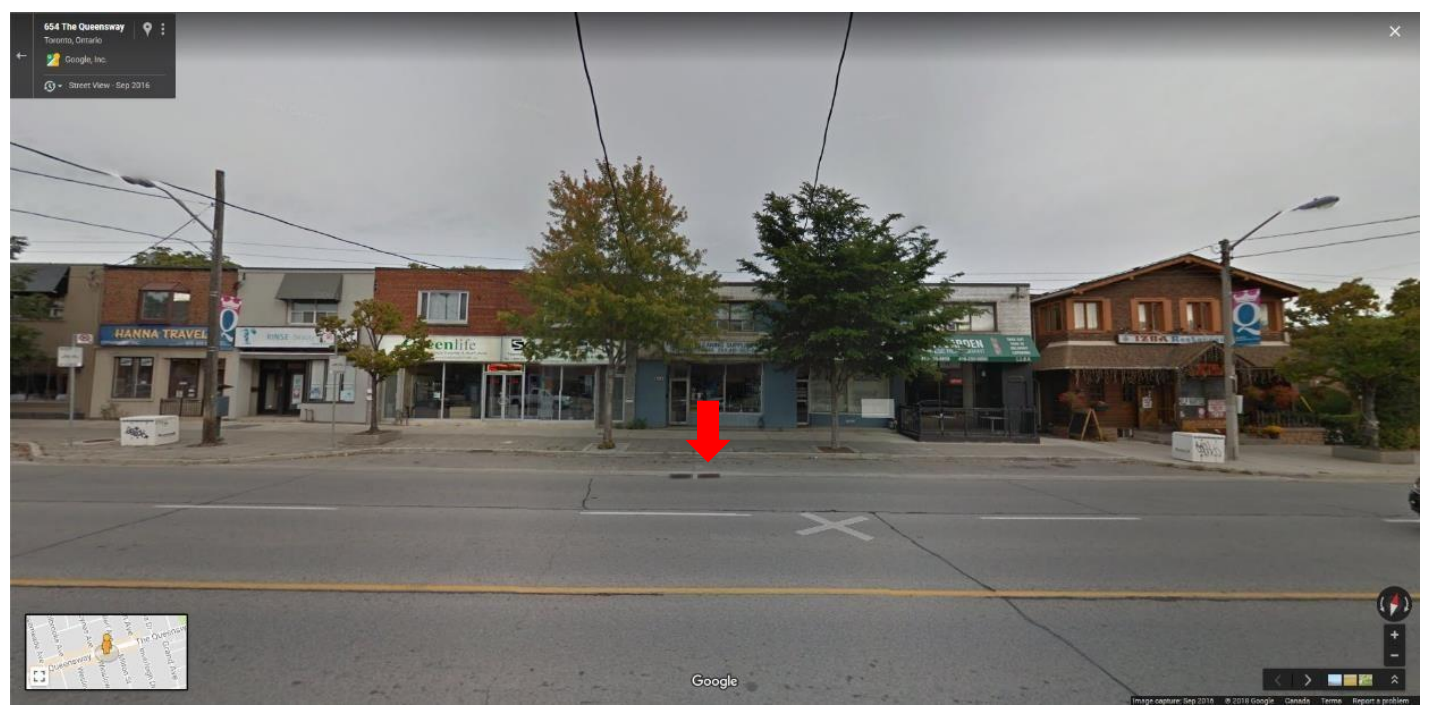

Figure 14. Inlet Drainage Basin of the Soil Cell (Facing North) 


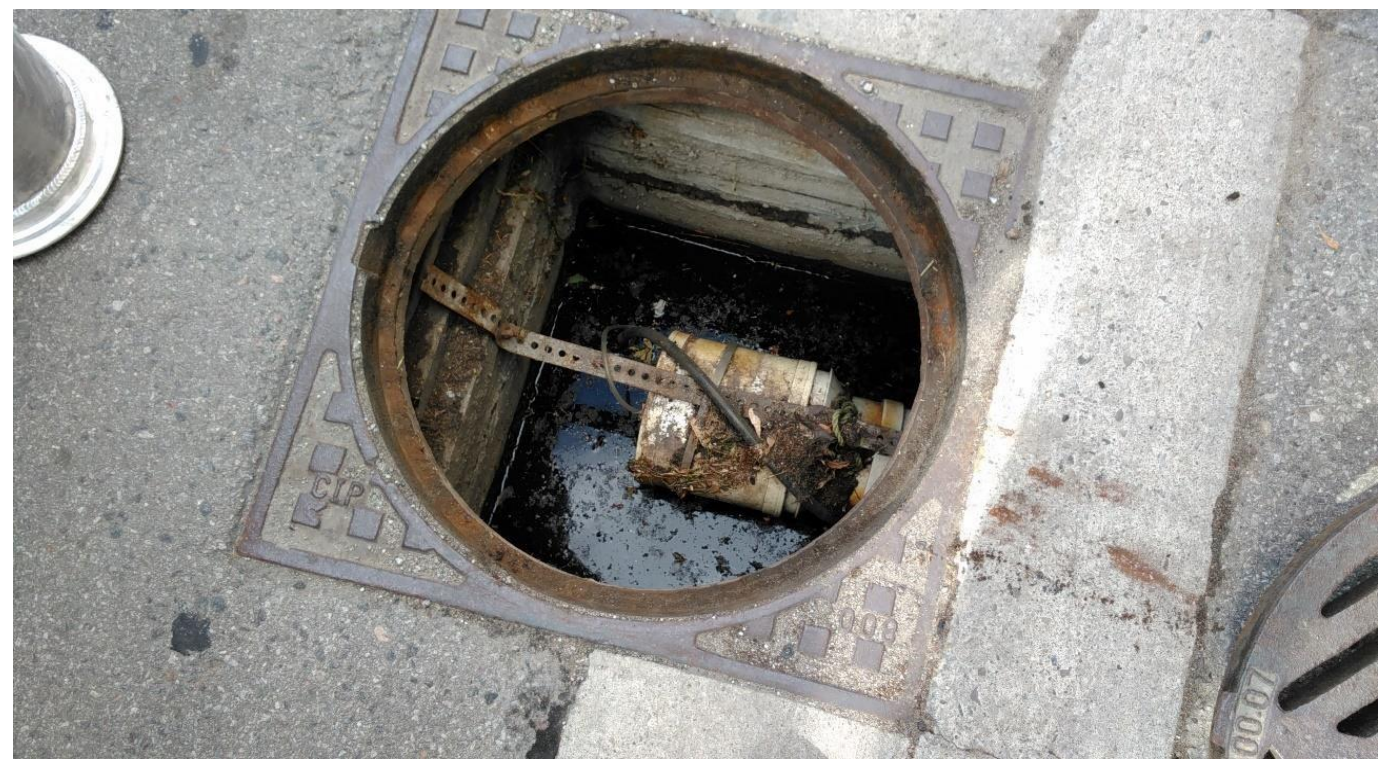

Figure 15. Inlet Pipe in the Drainage Basin

A loop of 6-inch perforated corrugated pipe is connected to the drainage basin, to serve as a distribution pipe for exfiltrating the runoff into the soil. A permeable textile was wrapped around the perforated pipe to prevent ingress of soil into the pipe. The soil cell is wrapped in an impermeable geotextile to prevent infiltration, this is due to local regulation prohibiting discharge of runoff into native soil from pollution hot spots such as a major arterial road. The loading from the sidewalk is supported with SilvaCell ${ }^{\mathrm{TM}}$ grid system such that the soil medium is not compacted by the surface load. The distribution pipe and SilvaCell ${ }^{\mathrm{TM}}$ can be seen during the construction of the soil cell in Figure 16. 


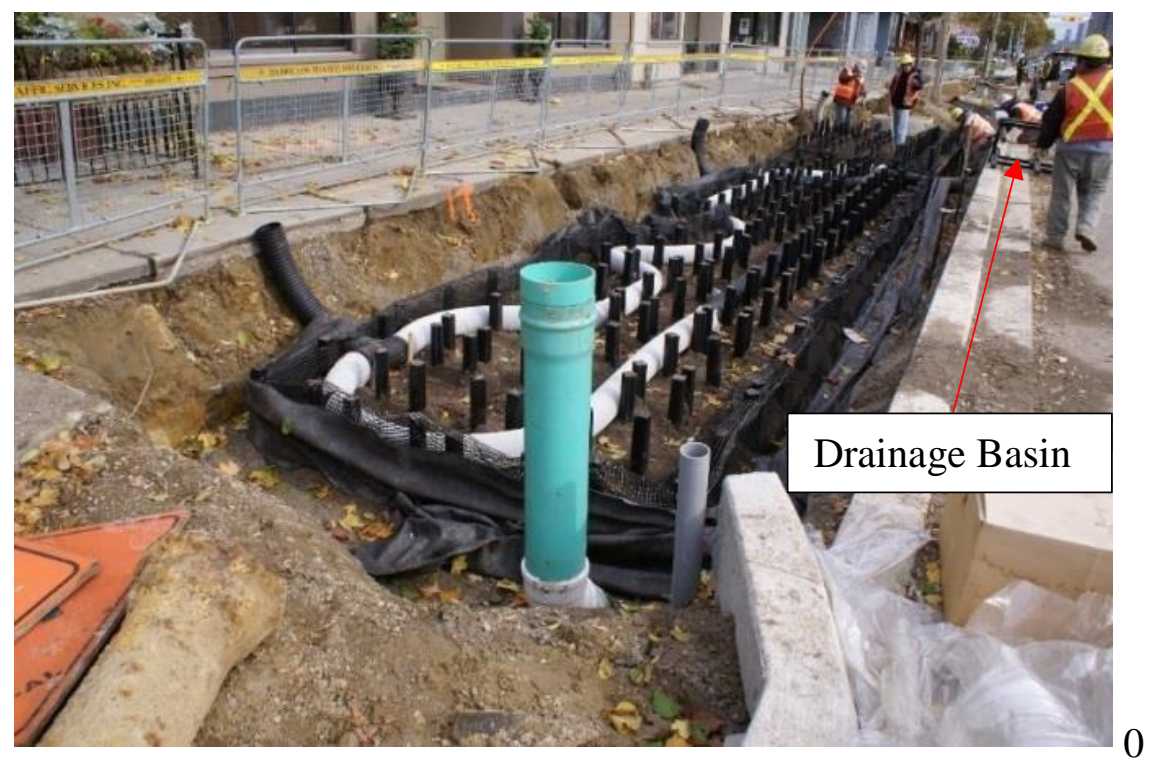

Figure 16. Soil Cell During Construction

A corrugated perforated pipe is placed at the bottom of the soil cell to drain the excess moisture and discharge it into the municipal storm sewer. The outfall location of the soil cell is shown in Figure 18. The soil cell is then paved over with impermeable concrete and utilized as a normal concrete sidewalk as shown in Figure 17.

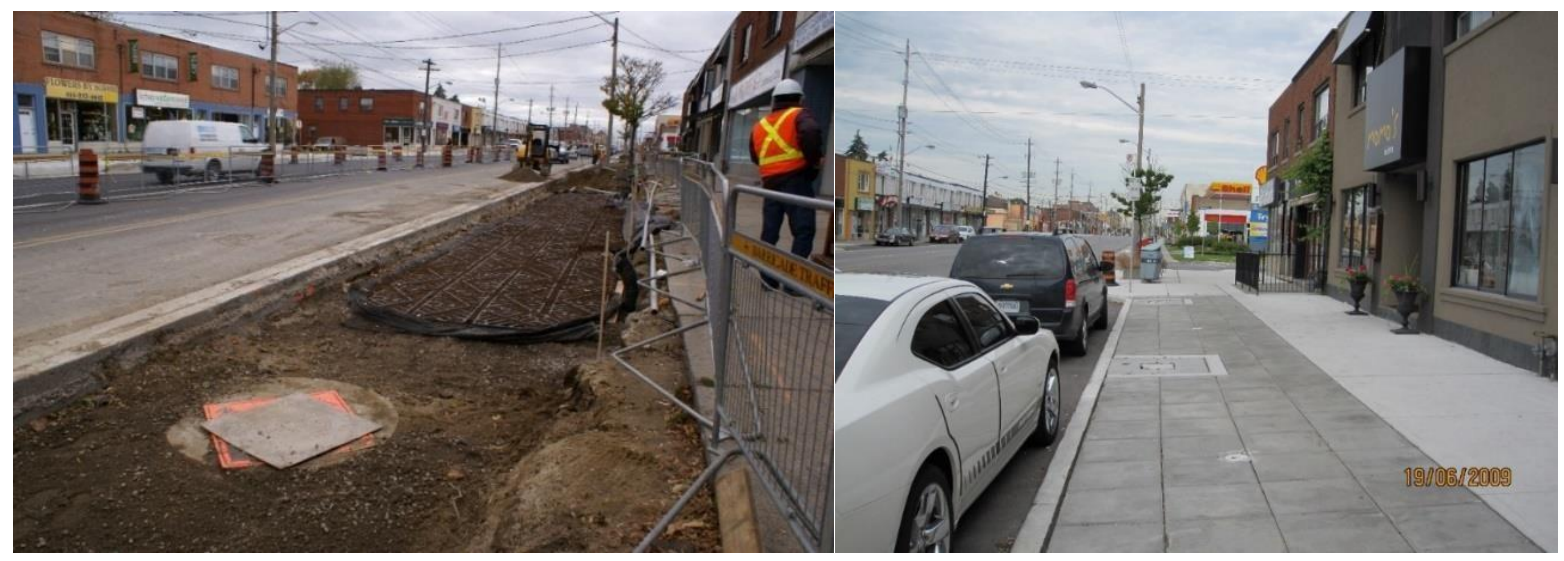

Figure 17. Completed Soil Cell

The dimension of the East Cell is approximately $15 \mathrm{~m}$ long by $2.4 \mathrm{~m}$ wide and $0.6 \mathrm{~m}$ deep.

The drawing for the soil cell is provided in Appendix I. 
Four trees were planted into the soil cell in 2011, two in the west cell and two in the east cell.

The locations of trees are shown in Figure 18.

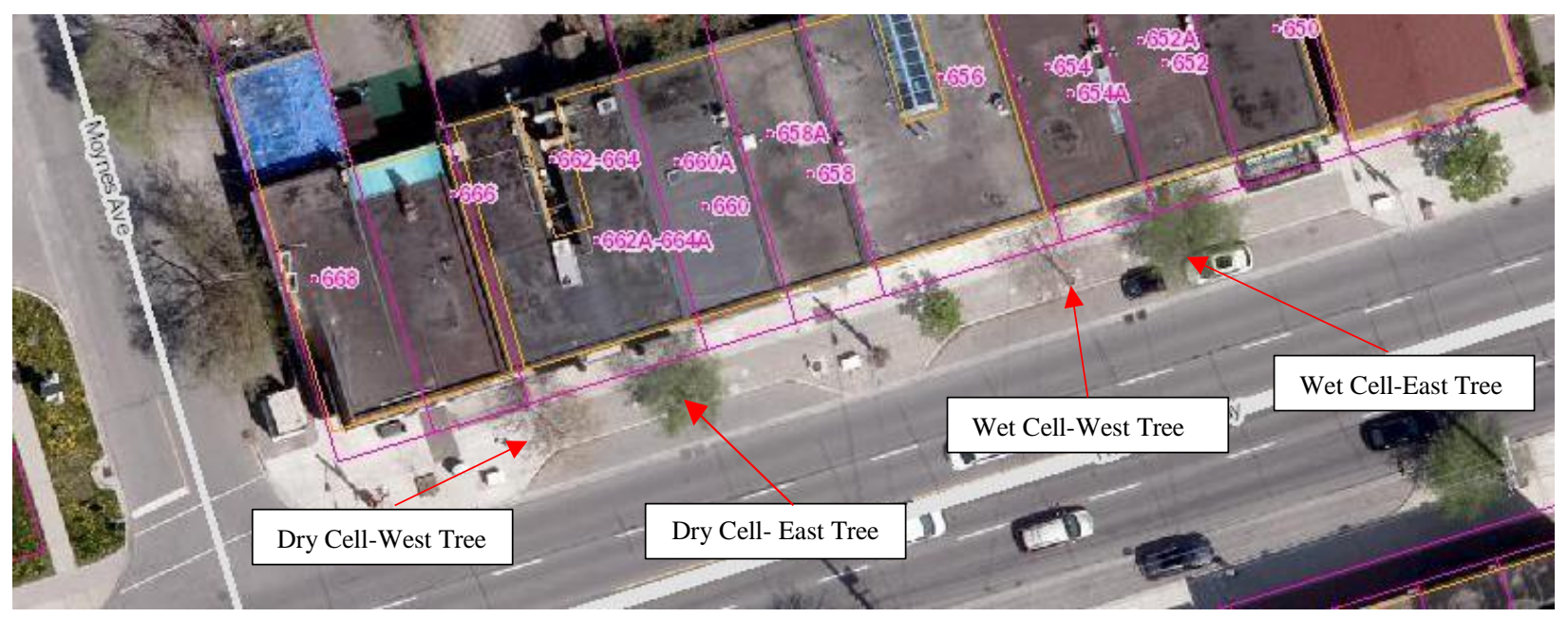

Figure 18. Configurations of Trees in Soil Cells

The backfilled material was sieve tested by Uddin (Uddin 2012), it was determined the composition was $98 \%$ sand and 2\% fines, the PSD is plotted in Figure 19 below.

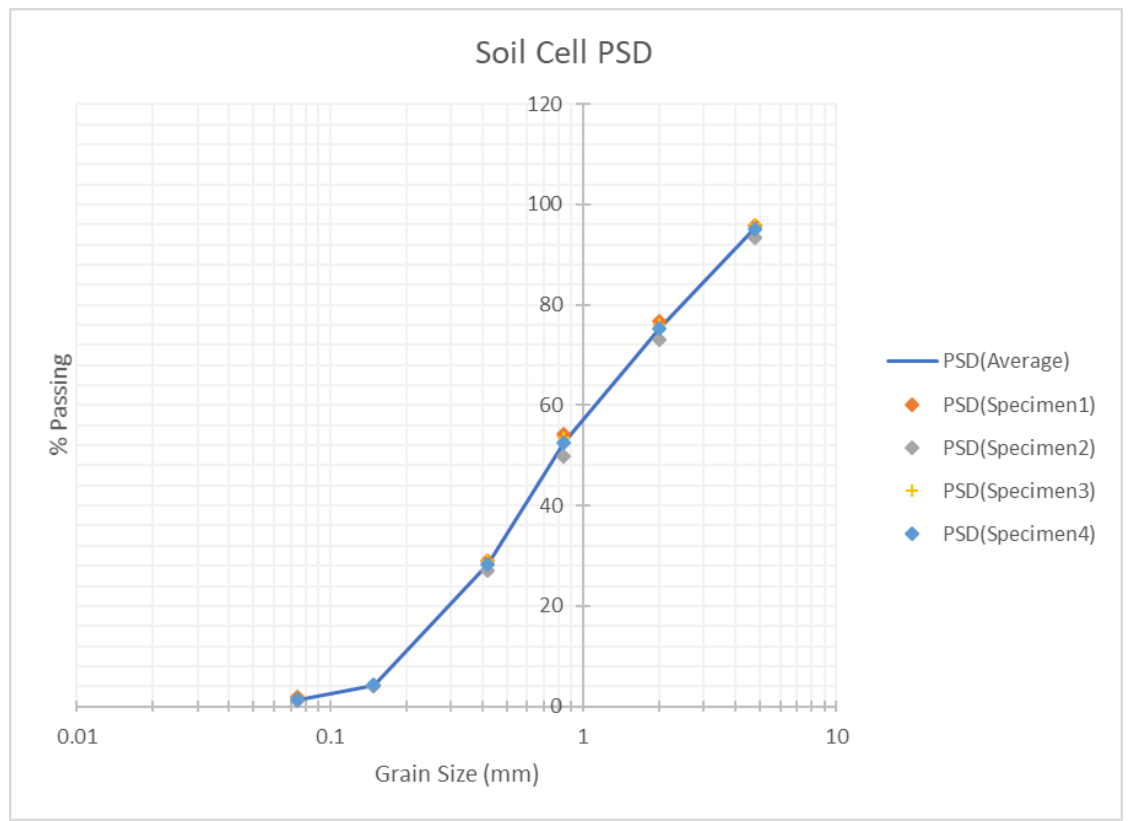

Figure 19. Particle Size Distribution of the backfill material 


\subsubsection{Monitoring Operations}

The 2016 monitoring operation extended from January $8^{\text {th }}$ to December $6^{\text {th }}$, with water quality and quantity both monitored. The monitored water quantity parameters include inflow and outflow rate, soil medium moisture content and water level inside the soil cell. Monitored water quality parameters included the centration of TSS, certain metals, phosphorus and nitrates, chloride and BOD. Other parameters related to the performance of the soil cell includes rainfall, and tree crown sizes which were obtained from the archived aerial photo.

Role and Responsibilities: As the monitoring operation was a collaborative effort between City of Toronto and Ryerson University, both sides contributed to the operation. The Ryerson team consisted of Lianghao Chen (the author) and Amir Alinaghian. The responsibility of the team was to conduct field visits after each storm event to download the data from the data loggers and preserve any water samples from the autosampler by refrigerating. Arrangements to prepare and process the samples were made with City of Toronto water lab whenever samples were produced.

City of Toronto was responsible for maintaining the proper function of the equipment, any challenges encountered were reported to the City and solutions were provided whenever possible. City of Toronto water lab was also responsible for testing prepared samples, sample preparation is Water Sampling section below.

Rate of Inflow / Outflow: The inflow rate was measured via weir installed at the inlet near the drainage basin, and the outflow rate was measured via weir installed near the outfall where the bottom perforated pipe discharges into the storm sewer. 
The water depths were measured by bubbler modules at the immediate upstream of the weir. The bubblers are attached to automatic sampler at the inlet and outlet locations, housed in the instrument hut shown in Figure 13.

Details regarding the weirs, bubbler module, and sampler including the construction and the models are provided in Table 5.

Water Sampling: In addition to measuring water depth, the bubbler can also take water samples when the attached to the autosampler. The autosampler is programmed to take samples when flow depth reaches $0.05 \mathrm{~m}$ above the inlet weir, and $0.06 \mathrm{~m}$ at the outlet. Time portioned sampling approach was used in this operation. Aliquot samples were taken at 5 minutes interval for the first 6 bottles and 10 minutes interval for the remaining 8 bottles.

Aliquot samples were kept refrigerated by the autosampler and delivered to the City of Toronto water lab, located at 33 Commissioner St, and prepared for processing within 72 hours of the rain event to ensure sample is not deteriorate during storage. Two composite samples were created for each event; one set for influent and one set for effluent. Composite samples were created by combining an equal amount of each of the aliquot sample bottles collected from the inlet or outlet. These composite samples are used as surrogates for event mean concentration. A set of filtered samples were prepared by filtering a portion of the composite sample through a $0.45 \mu \mathrm{m}$ filter paper. Additionally, a set of unfiltered samples were prepared by taking a portion of the composite sample. Filtered and unfiltered samples were prepared for both influent and effluent composite samples; thus a total of four samples 
were submitted to the lab for each event. City of Toronto lab analyzed the samples for a list of pollutants shown in Table 4.

Table 4. Pollutants Analyzed in the Monitoring Operation

\begin{tabular}{|c|c|c|}
\hline \multirow{3}{*}{$\begin{array}{c}\text { Contaminant } \\
\text { Category }\end{array}$} & Pollutants & Detection Limits \\
\hline \multirow{4}{*}{ Metal } & Aluminium & $0.01 \mathrm{mg} / \mathrm{L}$ \\
\cline { 2 - 3 } & Copper & $0.0005 \mathrm{mg} / \mathrm{L}$ \\
\cline { 2 - 3 } & Iron & $0.01 \mathrm{mg} / \mathrm{L}$ \\
\cline { 2 - 3 } & Lead & $0.00005 \mathrm{mg} / \mathrm{L}$ \\
\cline { 2 - 3 } & Nickel & $0.0002 \mathrm{mg} / \mathrm{L}$ \\
\hline \multirow{2}{*}{ Nutrients } & Zinc & $0.01 \mathrm{mg} / \mathrm{L}$ \\
\hline \multirow{2}{*}{$\begin{array}{l}\text { Other } \\
\text { Pollutants }\end{array}$} & Nitrate (as N) & $0.01 \mathrm{mg} / \mathrm{L}$ \\
\cline { 2 - 3 } & Total Phosphorus(mg/L) & $0.01 \mathrm{mg} / \mathrm{L}$ \\
\cline { 2 - 3 } & Total Suspended Solids (TSS) & $2 \mathrm{mg} / \mathrm{L}$ \\
\cline { 2 - 3 } & Chemical Oxygen Demand (BOD) & $0.2 \mathrm{mg} / \mathrm{L}$ \\
\hline
\end{tabular}

Soil Moisture: Two moisture sensors were placed near the inlet and outlet in the soil. Measurements were taken at $0.0 \mathrm{~m}, 0.2 \mathrm{~m}, 0.4 \mathrm{~m}$, and $0.6 \mathrm{~m}$ depth. The moisture sensor data was recorded with a data logger, and the moisture measurements were recorded at a continuous 5-minute interval.

The precise locations of the sensors are shown in a drawing which can be found in Appendix I.

Soil Water Level: Water level within the soil was measured with a submersible

pressure transducer. Measurements were taken at a 5-minute interval continuously.

The data were logged with $\mathrm{HOBO}^{\mathrm{TM}}$ data logger.

Data logger malfunctioned during July 10th to August $8^{\text {th }}, 2016$, and again from September 8th to October 7th, therefore the soil water level data for these dates were not available. 
Rainfall: A heated rain gauge was placed at the intersection of Moynes Ave and The Queensway as shown in Figure 7. The rain gauge measured rainfall depth using tip bucket, with a precision of $0.2 \mathrm{~mm}$, and the time of each tip was recorded with $\mathrm{HOBO}^{\mathrm{TM}}$ data logger, with precision in seconds.

The rain gauge is capable of measuring both rainfall and snowfall as it is heated to melt snow, though it is not capable of distinguishing between the two types of precipitation.

The complete list of equipment, their location and function are shown in Table 5 below.

Table 5. List of Equipment Used in Monitoring Operation, and Equipment's Locations and Purposes

\begin{tabular}{|c|c|c|}
\hline Equipment & Location & Purpose \\
\hline $\begin{array}{l}\text { Automatic Rain Gauge and } \\
\mathrm{HOBO}^{\mathrm{TM}} \text { Data Logger }\end{array}$ & $\begin{array}{l}\text { Intersection of Moynes Ave } \\
\text { and The Queensway }\end{array}$ & $\begin{array}{l}\text { Real-time rainfall } \\
\text { measurement }\end{array}$ \\
\hline 6" Thel-mar Weir & Inlet & Inflow rate measurement \\
\hline $\begin{array}{l}\text { Avalanche }{ }^{\circledR} \text { Automatic } \\
\text { Sampler and logger }\end{array}$ & $\begin{array}{l}\text { Inlet and Outlet Instrument } \\
\text { Box }\end{array}$ & Sample collection \\
\hline 730 Bubbler Flow Module & $\begin{array}{l}\text { Inlet and Outlet Instrument } \\
\text { Box, attached to sampler }\end{array}$ & Water depth measurement \\
\hline Weir & Outlet & $\begin{array}{l}\text { Outflow rate } \\
\text { measurement }\end{array}$ \\
\hline PR2/4 Soil Moisture Sensor & $\begin{array}{l}\text { Inlet and Outlet Instrument } \\
\text { Box }\end{array}$ & \multirow{2}{*}{$\begin{array}{l}\text { Soil moisture } \\
\text { measurement }\end{array}$} \\
\hline DL6 Data Logger & $\begin{array}{l}\text { Inlet and Outlet Instrument } \\
\text { Box }\end{array}$ & \\
\hline $\begin{array}{l}\text { PS-9800 Submersible Pressure } \\
\text { Transducer }\end{array}$ & & \multirow{2}{*}{$\begin{array}{l}\text { To measure water level } \\
\text { inside soil cell }\end{array}$} \\
\hline $\begin{array}{l}\mathrm{HOBO}^{\mathrm{TM}} \mathrm{RX} 3000 \text { Data } \\
\text { Logger }\end{array}$ & Outlet Instrument Box & \\
\hline
\end{tabular}

The detailed monitoring plan (Eric n.d.) is provided in Appendix II.

The rating curve for inlet and outlet weir are provided by manufactures and are shown in Appendix III and IV respectively. 


\section{Tree Health}

No measurement on trees was taken, as it was not identified as a focus of the monitoring operation. However, The City of Toronto maintains aerial images that cover the site over many years, and the trees are visible in these photos. These photos will be used to measure the growth of the crown.

\section{Data Processing}

A plot is generated for each rainfall event in Microsoft Excel. The rainfall intensity, inflow water level, and outflow water level are plotted against the time axis in one figure. The height of bottom and top of the weir notch relative to the bottom of the pipe is shown as a reference. The times which the samples are taken at are also shown in the figure.

The hydrograph at inlet and outlet were calculated as per manufacturer's specifications and are plotted in the lower subplot. In cases where water rose above the instruments' range, those measurements were dropped, and the corresponding flow rate was considered as 0 (high water level above the instrument range is considered a sign of stagnant water level rather than high flow rate, therefore it is considered as 0. See Figure 9 in 2.1.2).

The water level inside the cell is plotted against the time axis, and the soil moisture is plotted on a heat-map style graph at the same time axis.

A complete list of the two plots for each event are available in Appendix III and Appendix IV 


\subsection{Hydraulic performance of Perforated Pipe}

Collect and analysis of data collected on hydraulic experiment performed on a full-scale model allows for further the understanding of exfiltration performance of perforated pipe under open channel flow condition. The methodology and experimental setup will be discussed in section 3.2.1.

\subsubsection{Methodology}

A physical experiment was performed to measure the hydraulic profile within the pipe and the exfiltration rate of the perforated pipe. The pipe, which is the subject of the experiment, is a 6.7meter long section of a 6-inch diameter corrugated High-Density Polyethylene (HDPE) pipe provided by Armtec Inc as per American Association of State Highway and Transportation Officials (AASHTO) M252 Type C standard. The drawing of the AASHTO M252 Type C pipe is shown in Figure 20, and dimensions of the pipe is shown in

\section{Table 6.}
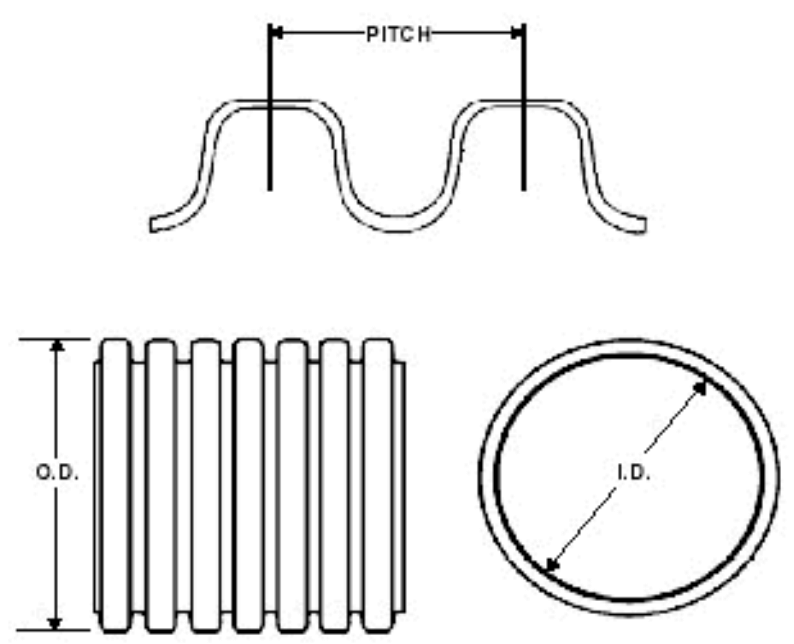

Figure 20. Typical Drawing of AASHTO M252 Type C Pipe 
(Hancor AASHTO Pipe Specification n.d.)

Table 6. 6-Inch AASHTO M252 Type C Dimensions
\begin{tabular}{|l|l|}
\hline Parameter & Measurement \\
\hline Inside Diameter (I.D) & $6 " / 150 \mathrm{~mm}$ \\
\hline Outside Diameter (O.D) & $7 " / 177 \mathrm{~mm}$ \\
\hline Pitch & $0.7 " / 18 \mathrm{~mm}$ \\
\hline
\end{tabular}

Four perforations are cut into every groove of the pipe, at 90 degrees apart by the manufacturer. The perforations are approximately $25 \mathrm{~mm}$ in length and $2.5 \mathrm{~mm}$ in width. The precision of the cuts is low as the perforations appear to have been cut manually. Additionally, the pipe was wrapped in woven geotextile.

The perforation patterns are shown in Figure 21.

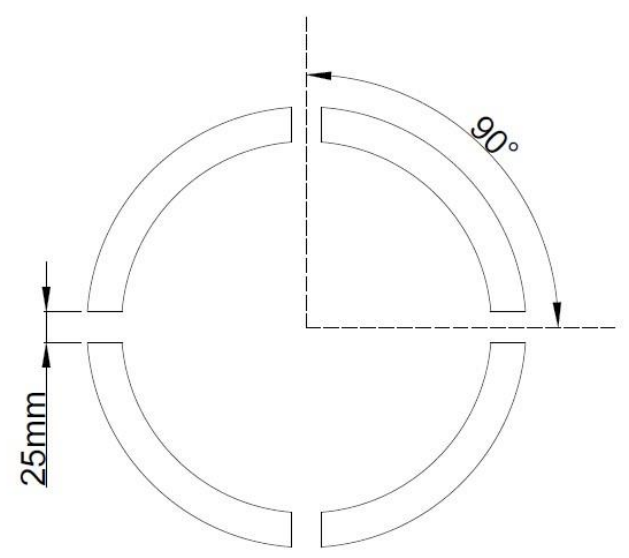

Figure 21. Perforation Pattern of the Pipe Used in The Experiment

The hydraulic performance is measured using an apparatus, similar to the Duchene and McBean study discussed in Section 2.2. The setup for the experiment is shown in Figure 22. 


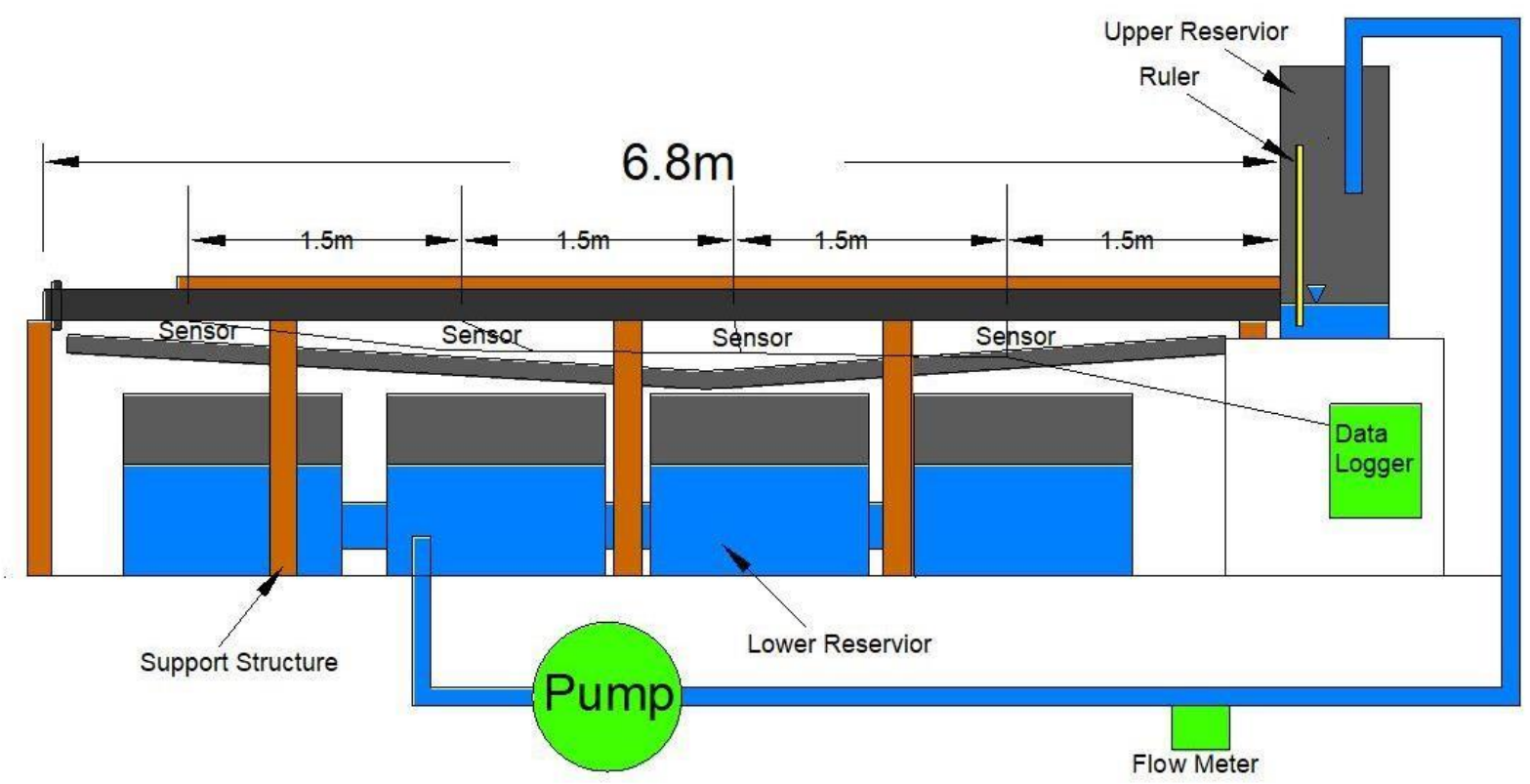

Figure 22. Exfiltration Pipe Experiment Apparatus Schematic

The apparatus comprises of an upper reservoir, made of a semi-transparent barrel with a $30 \mathrm{~cm}$ section of a 6" rigid pipe protruding out near the bottom to serve as an outlet and a connection. The upper reservoir is placed on a table. The lower reservoir is made of 4 water tanks placed on the floor; the bottom reservoirs are interconnected at a location near the bottom to accommodate a free flow of water between the four tanks. The perforated pipe is connected to the to the upper reservoir using a watertight rubber corrugated to a rigid pipe coupling supplied by Fernco (Part \#:1070-66), and downstream is capped using the same coupling, connected to a section of capped 6" PVC pipe. Support is required for the perforated pipe as it is flexible. Four support piers support the pipe from the bottom. The pipe fasts to a series of two-by-four placed on top of the pipe to prevent sagging between piers using metal straps; the straps were placed on the crest of the corrugation as to not interfere with exfiltration from perforation. The support piers were leveled to each other using a spirit level, and the alignment of the pipe was straightened via visual inspection. 
The water at the bottom reservoir is pumped to the upper reservoir using an IntelliflowXF variable speed pump through a 2-inch PVC rigid pipe. The flow rate is measured at the downstream of the pump using a F-1000 paddle wheel flowmeter manufactured by Blue-White Industries, Ltd. It should be noted that the flow meter only provided real-time display of flow rate and does not provide data storage.

As the water level at the upper reservoir rises, the flow into the perforated pipe is exfiltrated through the perforation and collected by a gutter system and returned to the lower reservoir. Four 1/4-inch holes were drilled manually at the bottom of the pipe at 1.5 meters apart, starting from the entrance of the perforated pipe. The screw thread at the top of Omega PX309 pressure transducers screwed tightly into the four holes. The pressure transducers are wired to a Sutron 9210 Xlite Data logger.

The apparatus attempts to simulate the perforated pipe used in the soil cell, it should be noted though the pipe is the same used in the field, the pipe is in the field is surrounded by soil where as the apparatus is not. The underlaying assumption of this model is that the soil medium does not limit the exfiltration rate of the pipe.

A photo of the apparatus is shown in Figure 23. 


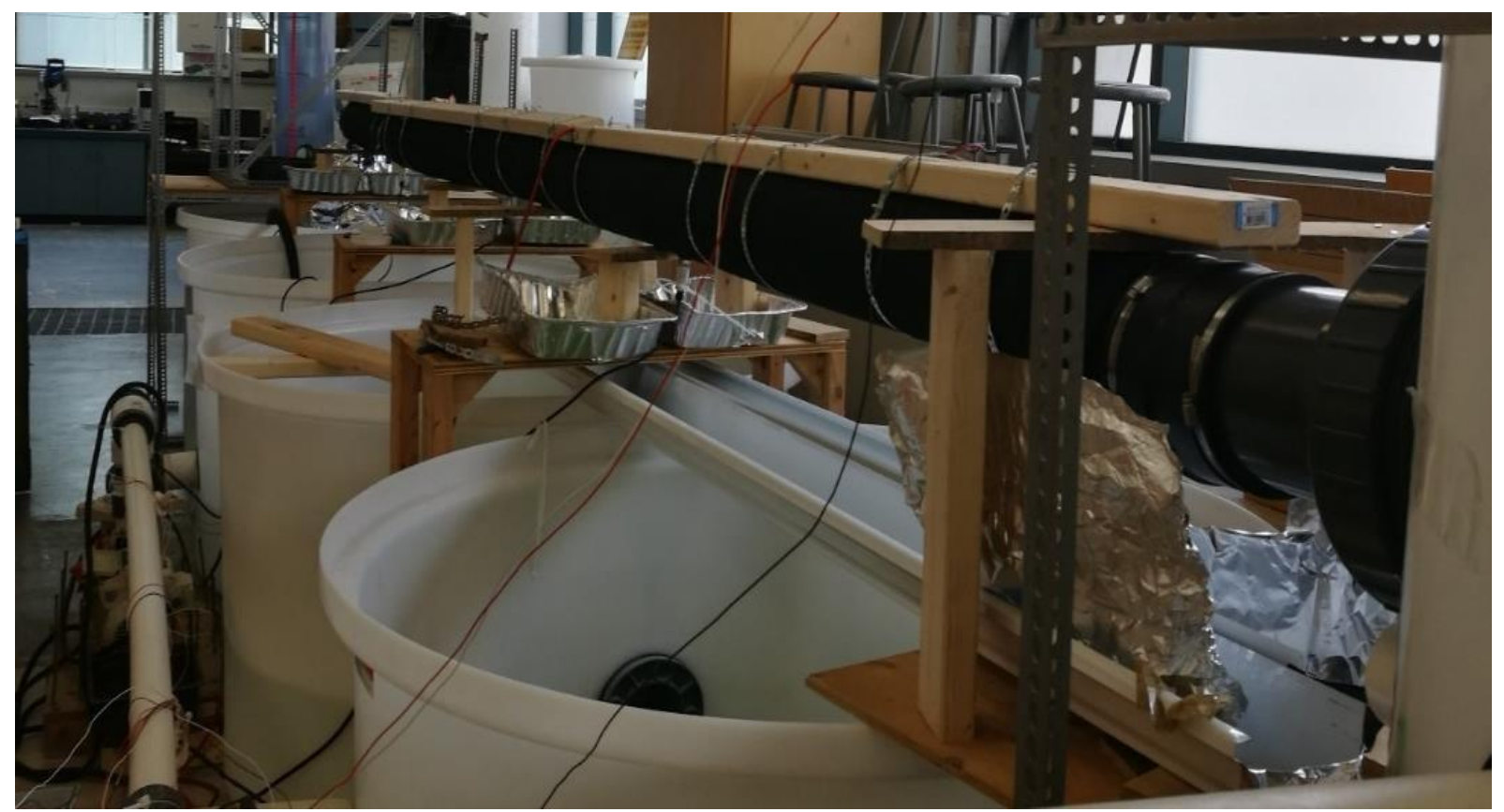

Figure 23. Exfiltration Pipe Experiment Apparatus Photo

Measurements were taken at various flow rates, ranging from $0.63 \mathrm{~L} / \mathrm{s}$ to $10.28 \mathrm{~L} / \mathrm{s}$. After the adjustment of the flowrates, the water level in the upper tank was given five minutes to stabilize before any measurements were taken. Measurements were taken at five-minute time intervals. The length of the pipe was $6.7 \mathrm{~m}$ long, approximately $1 / 4$ of the length of the loop. The experiment attempts to replicate the field condition of one side of the loop as the inlet is located in the middle of the loop. 


\section{Results and Discussion}

The result and discussion section will be broken down into two sections, section 4.1 will discuss the performance of the soil cell and section 4.2 will discuss the hydraulic performance of the perforated pipe.

\subsection{Performance of Soil Cell}

\subsubsection{Precipitation}

The rainfall record was available starting January $8^{\text {th }}, 2016$. The complete monthly precipitation records from February to December were obtained. The historical precipitation data obtained at Toronto Pearson International Airport from 1961 to 2016 is plotted as box plot in Figure 24, and this is considered as the weather norm. The 2016 data is plotted as line in the same figure for comparison.

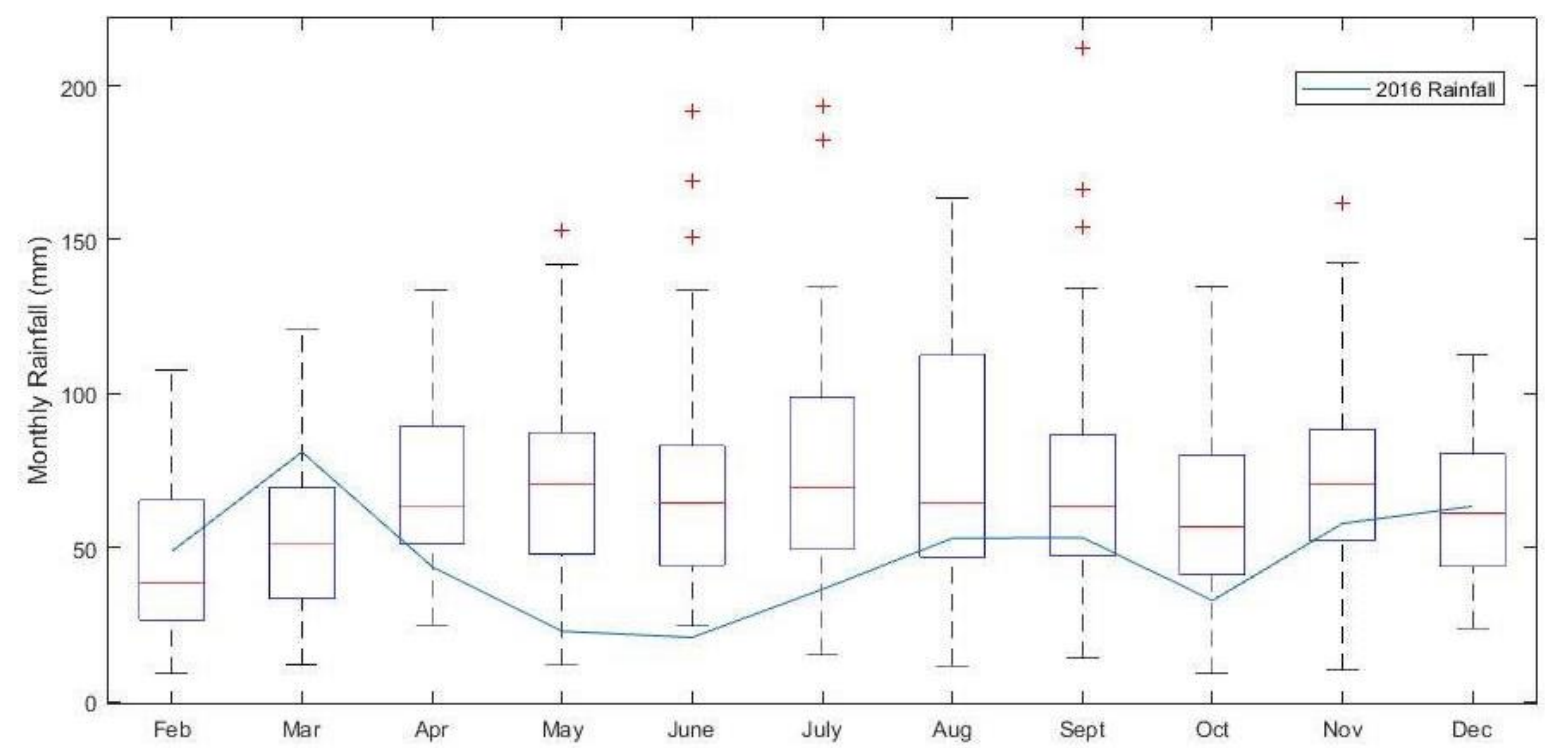

Figure 24. 2016 Monthly Rainfall Compare to Historical Record (1961-2012) 
From the data it is apparent that 2016 was an exceptionally dry year. Precipitation in majority of the months were below average and the summer months were typically below the $1^{\text {st }}$ quartile. The daily rainfall pattern in 2016 is compared against historical data from 1991. A typical year is defined by the City of Toronto's Wet Weather Flow Management Guideline and is shown in Figure 25.

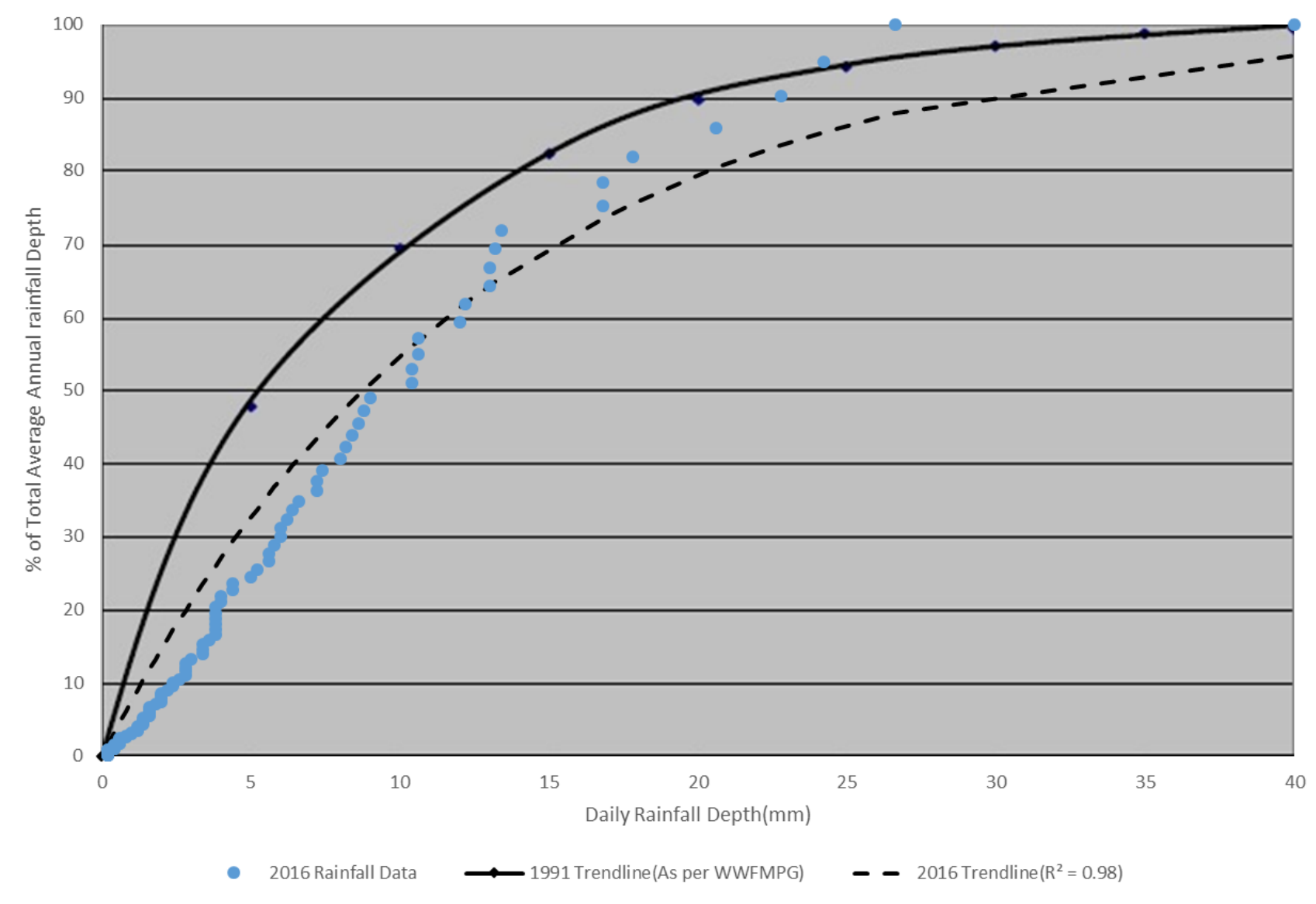

Figure 25. Cumulative Distribution of Daily Rainfall Depth as Percentage of Typical Annual Depth

Figure 25 shows daily events of $5 \mathrm{~mm}$ or less account for $50 \%$ of all events in a typical year, but rainfall of this intensity only accounted for less than 25\% in 2016. The overall trendline for 2016 suggests the daily rainfall intensity in 2016 is lower than that typical year. 


\subsubsection{Water Quality}

A total of 44 sets of samples were submitted. However due to the low flow level at the outlet, effluent samples were not available in a few events, matching influent and effluent sample sets were obtained for most events. The summary of sample sets is provided below in Table 7 .

Table 7. Summary of Samples Collected

\begin{tabular}{|l|l|l|l|}
\hline Pollutants & $\begin{array}{l}\text { Inlet } \\
\text { Samples }\end{array}$ & $\begin{array}{l}\text { Outlet } \\
\text { Samples }\end{array}$ & $\begin{array}{l}\text { Matching } \\
\text { Samples }\end{array}$ \\
\hline Aluminium & 29 & 25 & 21 \\
\hline Biochemical Oxygen Demand & 28 & 24 & 20 \\
\hline Chloride & 29 & 25 & 20 \\
\hline Copper & 29 & 25 & 21 \\
\hline Iron & 29 & 25 & 21 \\
\hline Lead & 29 & 25 & 21 \\
\hline Nickel & 29 & 25 & 21 \\
\hline Nitrate & 29 & 25 & 20 \\
\hline Total Phosphorus & 29 & 25 & 21 \\
\hline Total Suspended Solids & 30 & 26 & 22 \\
\hline Zinc & 29 & 24 & 21 \\
\hline
\end{tabular}

Distributions of all pollutants monitored were plotted in Figure 26 to Figure 59.

The event mean concentrations for some pollutants during events were reported as below the detection limit and actual value is unknown. In those cases the detection limit is conservatively taken as the concentration.

The summary of concentration reduction is provided in Table 8 . 
Table 8. Statistical Summary of Influent and Effluent Concentration

\begin{tabular}{|c|c|c|c|c|c|c|c|c|c|c|c|c|c|c|}
\hline \multirow[b]{2}{*}{ Pollutants } & \multicolumn{6}{|c|}{ Influent Concentration } & \multicolumn{6}{|c|}{ Effluent Concentration } & \multirow[b]{2}{*}{$\begin{array}{l}\text { Median Con } \\
\text { Reduction \% }\end{array}$} & \multirow[b]{2}{*}{$\begin{array}{c}\text { Significant? } \\
(\alpha<0.05)\end{array}$} \\
\hline & $\%<\mathrm{dl}$ & Min & $\operatorname{Max}$ & Mean & Median & St.Dev & $\%<\mathrm{dl}$ & Min & Max & Mean & Median & St.Dev & & \\
\hline $\begin{array}{c}\mathrm{Al} \\
(\mathrm{mg} / \mathrm{L})\end{array}$ & $3 \%$ & $\begin{array}{l}7.50 \\
\text { E-02 }\end{array}$ & $\begin{array}{c}1.00 \\
\mathrm{E}+01\end{array}$ & $\begin{array}{c}1.74 \\
\mathrm{E}+00\end{array}$ & $\begin{array}{l}6.78 \\
\mathrm{E}-01\end{array}$ & $\begin{array}{c}2.85 \mathrm{E} \\
+00\end{array}$ & $4 \%$ & $\begin{array}{l}2.50 \\
\text { E-02 }\end{array}$ & $\begin{array}{l}6.81 \\
\text { E-01 }\end{array}$ & $\begin{array}{l}1.91 \\
\text { E-01 }\end{array}$ & $\begin{array}{l}9.44 \\
\text { E-02 }\end{array}$ & $\begin{array}{l}2.18 \\
\text { E-01 }\end{array}$ & $82 \%$ & $\begin{array}{c}\text { Yes } \\
\mathrm{P}=0.0014\end{array}$ \\
\hline $\begin{array}{c}\text { BOD } \\
(\mathrm{mg} / \mathrm{L})\end{array}$ & $3 \%$ & $\begin{array}{c}0.00 \\
\mathrm{E}+00\end{array}$ & $\begin{array}{c}6.80 \\
E+01\end{array}$ & $\begin{array}{c}1.75 \\
\mathrm{E}+01\end{array}$ & $\begin{array}{c}8.00 \\
E+00\end{array}$ & $\begin{array}{c}2.07 \mathrm{E} \\
+01\end{array}$ & $36 \%$ & $\begin{array}{c}2.00 \\
E+00\end{array}$ & $\begin{array}{c}4.98 \\
\mathrm{E}+01\end{array}$ & $\begin{array}{c}6.00 \\
E+00\end{array}$ & $\begin{array}{c}2.50 \\
E+00\end{array}$ & $\begin{array}{c}1.11 \\
E+01\end{array}$ & $73 \%$ & $\begin{array}{c}\text { Yes } \\
\mathrm{P}=0.0044\end{array}$ \\
\hline $\begin{array}{c}\mathrm{Cl} \\
(\mathrm{mg} / \mathrm{L})\end{array}$ & $3 \%$ & $\begin{array}{c}1.10 \\
\mathrm{E}+00\end{array}$ & $\begin{array}{c}8.63 \\
\mathrm{E}+02 \\
\end{array}$ & $\begin{array}{c}1.70 \\
\mathrm{E}+02 \\
\end{array}$ & $\begin{array}{c}3.23 \\
E+01 \\
\end{array}$ & $\begin{array}{c}2.62 \mathrm{E} \\
+02 \\
\end{array}$ & $4 \%$ & $\begin{array}{c}1.10 \\
E+00\end{array}$ & $\begin{array}{c}2.85 \\
E+03\end{array}$ & $\begin{array}{c}5.45 \\
E+02 \\
\end{array}$ & $\begin{array}{c}3.38 \\
\mathrm{E}+01 \\
\end{array}$ & $\begin{array}{c}1.01 \\
E+03\end{array}$ & $-1 \%$ & $\begin{array}{c}\text { No } \\
\mathrm{P}=0.2044\end{array}$ \\
\hline $\begin{array}{c}\mathrm{Cu} \\
(\mathrm{mg} / \mathrm{L})\end{array}$ & $0 \%$ & $\begin{array}{l}5.00 \\
\text { E-03 }\end{array}$ & $\begin{array}{c}1.00 \\
\mathrm{E}+01\end{array}$ & $\begin{array}{l}8.63 \\
\text { E-01 }\end{array}$ & $\begin{array}{l}3.15 \\
\text { E-02 }\end{array}$ & $\begin{array}{c}2.88 \mathrm{E} \\
+00\end{array}$ & $0 \%$ & $\begin{array}{l}6.34 \\
\text { E-03 }\end{array}$ & $\begin{array}{c}3.1 \\
6 \mathrm{E}-02\end{array}$ & $\begin{array}{l}1.67 \\
\text { E-02 }\end{array}$ & $\begin{array}{l}1.34 \\
\text { E-02 }\end{array}$ & $\begin{array}{l}9.50 \\
\text { E-03 }\end{array}$ & $53 \%$ & $\begin{array}{c}\text { Yes } \\
\mathrm{P}=2.12 \mathrm{e}-05\end{array}$ \\
\hline $\begin{array}{c}\mathrm{Fe} \\
(\mathrm{mg} / \mathrm{L})\end{array}$ & $0 \%$ & $\begin{array}{l}2.68 \\
\text { E-01 }\end{array}$ & $\begin{array}{c}9.00 \\
E+00\end{array}$ & $\begin{array}{c}2.38 \\
\mathrm{E}+00\end{array}$ & $\begin{array}{c}1.29 \\
E+00\end{array}$ & $\begin{array}{c}2.84 \mathrm{E} \\
+00\end{array}$ & $0 \%$ & $\begin{array}{l}4.09 \\
\text { E-02 }\end{array}$ & $\begin{array}{r}6.99 \\
\text { E-01 } \\
\end{array}$ & $\begin{array}{l}2.59 \\
\text { E-01 }\end{array}$ & $\begin{array}{l}1.87 \\
\text { E-01 }\end{array}$ & $\begin{array}{l}2.36 \\
\text { E-01 }\end{array}$ & $90 \%$ & $\begin{array}{c}\text { Yes } \\
\mathrm{P}=1.50 \mathrm{e}-04\end{array}$ \\
\hline $\begin{array}{c}\mathrm{Pb} \\
(\mathrm{mg} / \mathrm{L})\end{array}$ & $0 \%$ & $\begin{array}{l}5.00 \\
\text { E-04 }\end{array}$ & $\begin{array}{c}1.00 \\
\mathrm{E}+01\end{array}$ & $\begin{array}{l}8.39 \\
\text { E-01 }\end{array}$ & $\begin{array}{l}5.89 \\
\text { E-03 }\end{array}$ & $\begin{array}{c}2.88 \mathrm{E} \\
+00\end{array}$ & $0 \%$ & $\begin{array}{l}1.43 \\
\text { E-04 }\end{array}$ & $\begin{array}{l}1.89 \\
\text { E-03 }\end{array}$ & $\begin{array}{l}7.00 \\
\text { E-04 }\end{array}$ & $\begin{array}{l}3.96 \\
\text { E-04 }\end{array}$ & $\begin{array}{l}6.57 \\
\text { E-04 }\end{array}$ & $91 \%$ & $\begin{array}{c}\text { Yes, } \\
\mathrm{P}=1.04 \mathrm{e}-04\end{array}$ \\
\hline $\begin{array}{c}\mathrm{Ni} \\
(\mu \mathrm{g} / \mathrm{L})\end{array}$ & $0 \%$ & $\begin{array}{c}0.00 \\
\mathrm{E}+00\end{array}$ & $\begin{array}{l}2.50 \\
\text { E-02 } \\
\end{array}$ & $\begin{array}{l}5.80 \\
\text { E-03 }\end{array}$ & $\begin{array}{l}4.36 \\
\text { E-03 }\end{array}$ & $\begin{array}{c}6.45 \mathrm{E}- \\
03 \\
\end{array}$ & $0 \%$ & $\begin{array}{l}5.00 \\
\text { E-04 }\end{array}$ & $\begin{array}{l}3.49 \\
\text { E-03 } \\
\end{array}$ & $\begin{array}{l}1.55 \\
\text { E-03 }\end{array}$ & $\begin{array}{l}1.03 \\
\text { E-03 }\end{array}$ & $\begin{array}{l}1.22 \\
\text { E-03 }\end{array}$ & $61 \%$ & $\begin{array}{c}\text { Yes } \\
\mathrm{P}=6.59 \mathrm{e}-05\end{array}$ \\
\hline $\begin{array}{c}\mathrm{NO}_{3}^{-} \\
(\mathrm{mg} / \mathrm{L})\end{array}$ & $38 \%$ & $\begin{array}{l}1.00 \\
\text { E-02 }\end{array}$ & $\begin{array}{c}1.90 \\
E+01\end{array}$ & $\begin{array}{c}1.28 \\
\mathrm{E}+00\end{array}$ & $\begin{array}{l}3.30 \\
\text { E-01 }\end{array}$ & $\begin{array}{c}3.88 \mathrm{E} \\
+00\end{array}$ & $19 \%$ & $\begin{array}{l}1.00 \\
\text { E-02 }\end{array}$ & $\begin{array}{c}1.26 \\
E+00\end{array}$ & $\begin{array}{l}4.98 \\
\text { E-01 }\end{array}$ & $\begin{array}{l}5.50 \\
\text { E-01 }\end{array}$ & $\begin{array}{l}3.54 \\
\text { E-01 }\end{array}$ & $-65 \%$ & $\begin{array}{c}\text { No } \\
\mathrm{P}=0.1894\end{array}$ \\
\hline $\begin{array}{c}\mathrm{TP} \\
(\mathrm{mg} / \mathrm{L})\end{array}$ & $0 \%$ & $\begin{array}{l}3.00 \\
\text { E-02 } \\
\end{array}$ & $\begin{array}{c}1.00 \\
\mathrm{E}+01 \\
\end{array}$ & $\begin{array}{c}1.09 \\
\mathrm{E}+00 \\
\end{array}$ & $\begin{array}{l}2.51 \\
\text { E-01 }\end{array}$ & $\begin{array}{c}2.81 \mathrm{E} \\
+00 \\
\end{array}$ & $0 \%$ & $\begin{array}{l}4.14 \\
\text { E-02 } \\
\end{array}$ & $\begin{array}{l}2.58 \\
\text { E-01 } \\
\end{array}$ & $\begin{array}{l}1.09 \\
\text { E-01 }\end{array}$ & $\begin{array}{l}6.48 \\
\text { E-02 } \\
\end{array}$ & $\begin{array}{l}8.44 \\
\text { E-02 } \\
\end{array}$ & $74 \%$ & $\begin{array}{c}\text { Yes } \\
\mathrm{P}=3.43 \mathrm{e}-04\end{array}$ \\
\hline $\begin{array}{c}\text { TSS } \\
(\mathrm{mg} / \mathrm{L})\end{array}$ & $3 \%$ & $\begin{array}{c}2.00 \\
E+00\end{array}$ & $\begin{array}{c}2.58 \\
E+02\end{array}$ & $\begin{array}{c}4.98 \\
E+01\end{array}$ & $\begin{array}{c}3.40 \\
\mathrm{E}+01\end{array}$ & $\begin{array}{c}6.80 \mathrm{E} \\
+01\end{array}$ & $15 \%$ & $\begin{array}{c}2.00 \\
\mathrm{E}+00\end{array}$ & $\begin{array}{c}1.70 \\
\mathrm{E}+01\end{array}$ & $\begin{array}{c}3.36 \\
E+00\end{array}$ & $\begin{array}{c}2.00 \\
E+00\end{array}$ & $\begin{array}{c}3.97 \\
E+00\end{array}$ & $92 \%$ & $\begin{array}{c}\text { Yes } \\
\mathrm{P}=1.27 \mathrm{e}-04\end{array}$ \\
\hline $\begin{array}{c}\mathrm{Zn} \\
(\mathrm{mg} / \mathrm{L})\end{array}$ & $10 \%$ & $\begin{array}{l}2.00 \\
\text { E-02 }\end{array}$ & $\begin{array}{c}1.40 \\
E+01\end{array}$ & $\begin{array}{c}1.09 \\
E+00\end{array}$ & $\begin{array}{l}1.15 \\
\text { E-01 }\end{array}$ & $\begin{array}{c}3.45 \mathrm{E} \\
+00\end{array}$ & $68 \%$ & $\begin{array}{l}2.50 \\
\text { E-02 }\end{array}$ & $\begin{array}{l}9.61 \\
\text { E-02 }\end{array}$ & $\begin{array}{l}2.90 \\
\text { E-02 }\end{array}$ & $\begin{array}{l}2.50 \\
\text { E-02 }\end{array}$ & $\begin{array}{l}1.68 \\
\text { E-02 }\end{array}$ & $71 \%$ & $\begin{array}{c}\text { Yes } \\
\mathrm{P}=0.0019\end{array}$ \\
\hline
\end{tabular}

List of abbreviations: $\mathrm{Al}=$ Aluminum, $\mathrm{BOD}=$ Biochemical Oxygen Demand, $\mathrm{Cl}=\mathrm{Chloride}, \mathrm{Cu}=\mathrm{Copper}, \mathrm{Fe}=\mathrm{Iron}, \mathrm{Pb}=\mathrm{Lead}$,

$\mathrm{Ni}=$ Nickel, $\mathrm{NO}_{3}{ }^{-}=$Nitrate, $\mathrm{TP}=$ Total Phosphorus, $\mathrm{TSS}=$ Total Suspended Solids, $\mathrm{Zn}=\mathrm{Zinc}, \mathrm{dl}=$ detection limit, $\mathrm{Con}=$

Concentration, $\mathrm{E} \pm \mathrm{n}=10^{ \pm \mathrm{n}}$

Significance Level $=0.05$ 


\section{TSS Concentration Reduction}

The soil cell has shown to have significantly reduced the concentration of TSS, achieving a reduction of $92 \%$. The distribution of influent and effluent TSS concentrations are provided in Figure 26 below.

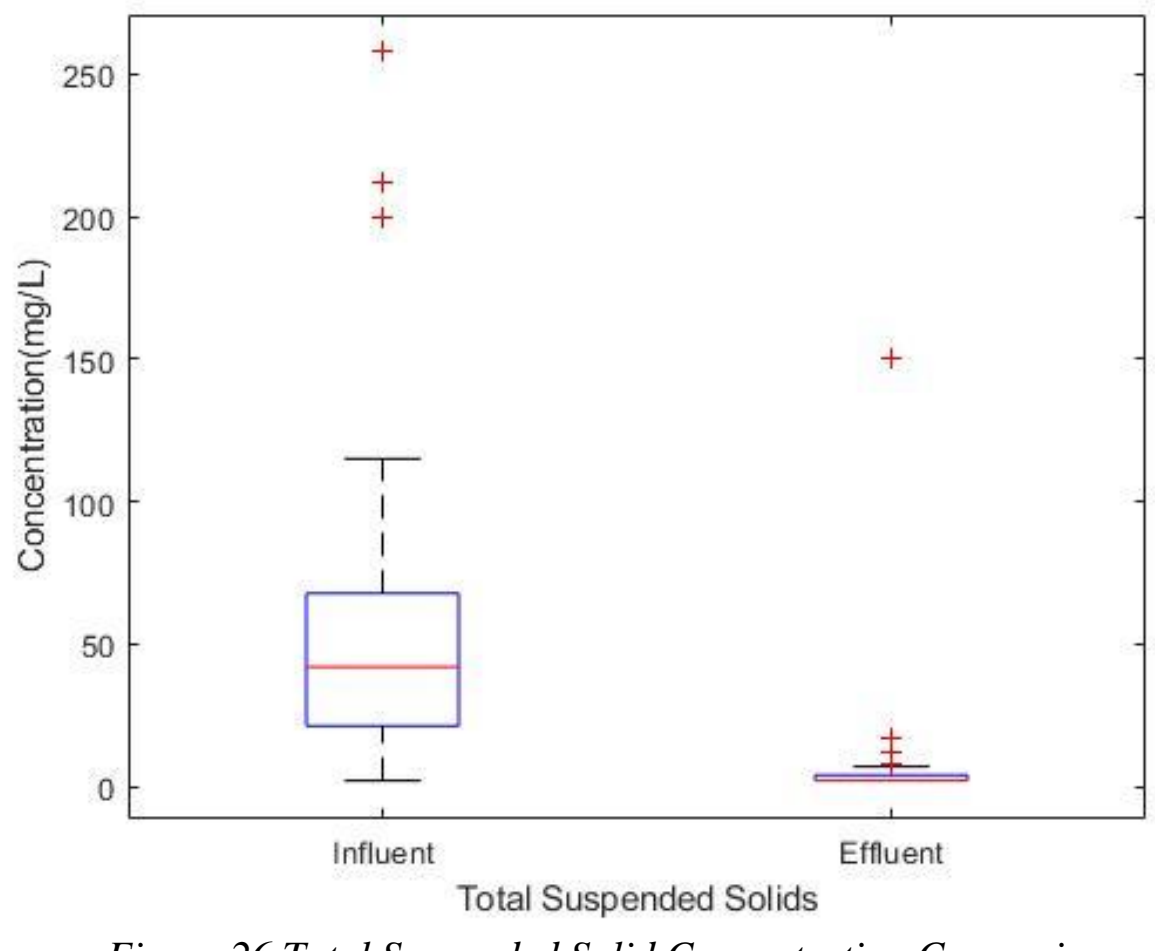

Figure 26.Total Suspended Solid Concentration Comparison

The pair-wise concentration for matching influent and effluent is plotted in Figure 27. A 45degree line is plotted for reference. a point above the line shows an event where the effluent concentration is greater than influent concentration and vice versa. 


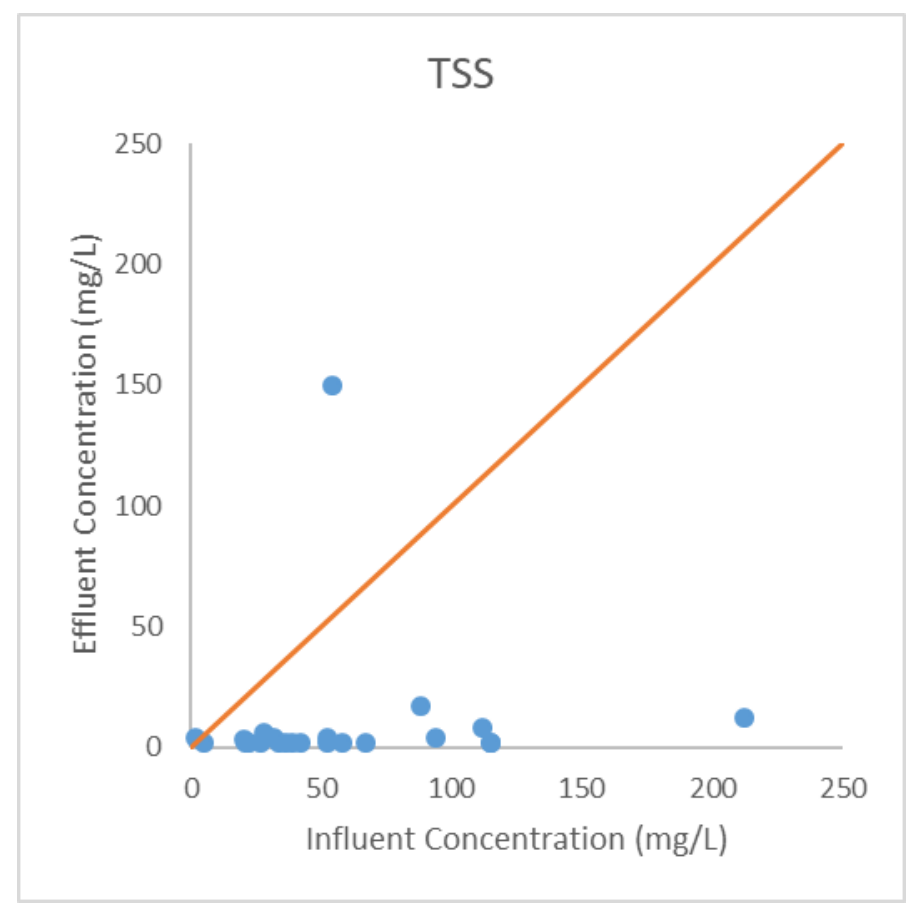

Figure 27. Pair Wise Comparison for TSS

The influent and effluent concentration shows no correlation $\left(\mathrm{R}^{2}=0.0043\right)$. To avoid the effects of road salt, the samples for summer months were plotted but shows weak correlation between influent and effluent correlation $\left(\mathrm{R}^{2}=0.33\right)$.

The lack of correlation between influent and effluent TSS concentration was also observed by Khan et al. made similar observation was made by Khan et al. in their Calgary study, they suggest that effluent concentration is primarily dependent on the sediment present in the backfill media rather than the influent itself. It should be also noted Khan et al. recognizes their observations are in conflict with others (Khan et al. 2012b).

The temporal distribution of TSS reduction is plotted against TSS and the chloride load in Figure 28. The concentration of the TSS is plotted against the left axis while Chloride concentrations are plotted against right axis. 


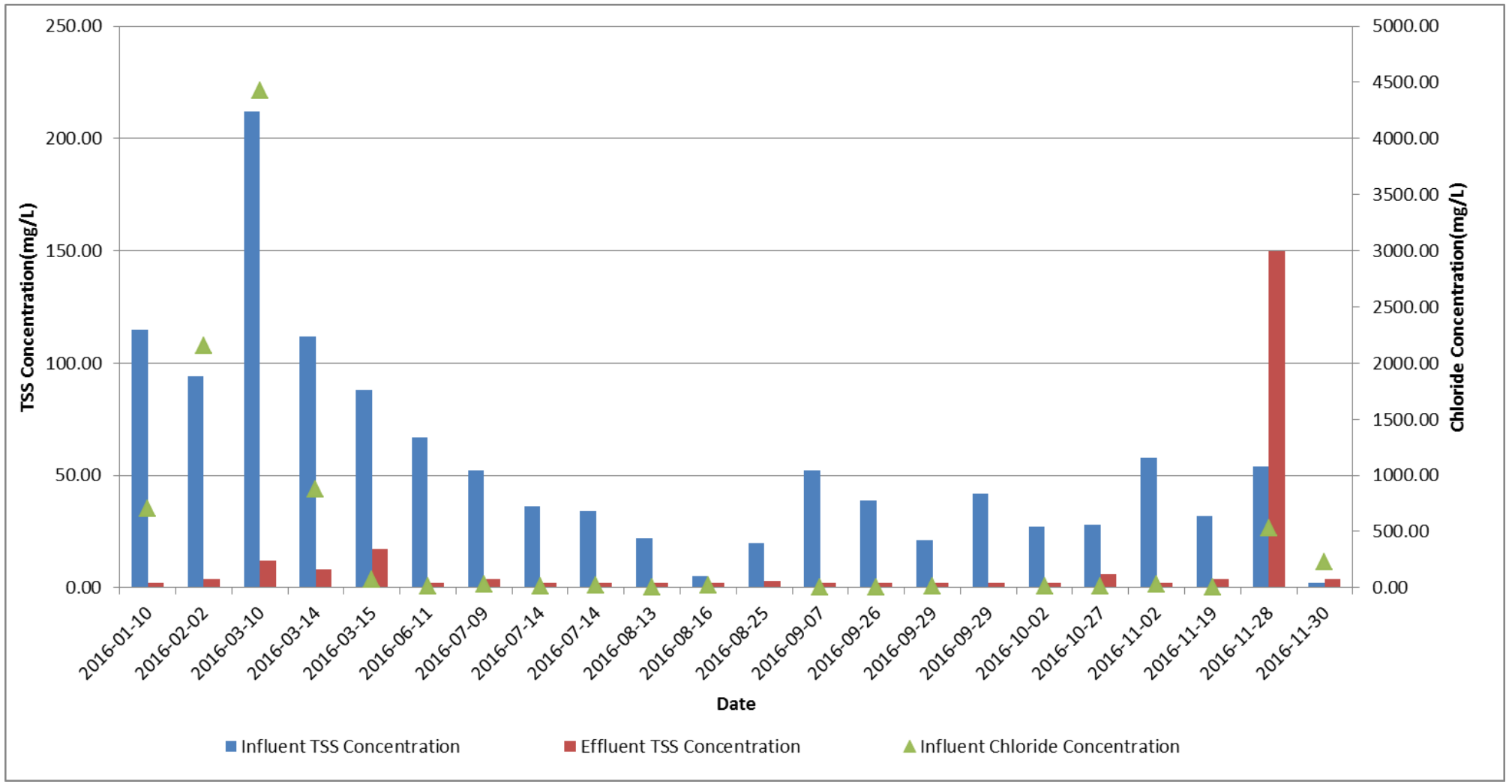

Figure 28. Temporal Distribution of TSS Reduction, TSS and Chloride Loading in 2016

High TSS concentration reduction efficiency was observed for most of the year, with the exception of two events in late autumn (November 26 and 30) where the effluent concentration increased. The increase of TSS in late winter coincided with the first applications of road salt in the winter as evidenced by the chloride concentration spike that occurred at the same time the influent TSS concentration did not significantly increase. Most studies on bioretention have shown good TSS treatment performance in winter (Khan et al. 2012b; Davis et al. 2001), this is also observed in soil cell in this case despite the two leaching events.

Studies that have shown good winter performance did not examine specific events in detail, but chloride is known to decrease mobilization of fine particulates, as Roseen et al. pointed out theoretical settling velocity of $100 \mu \mathrm{m}$ sphere can be reduced to half from " $30^{\circ} \mathrm{C}$ with no chloride 
to $0^{\circ} \mathrm{C}$ with a chloride content equivalent to $1 / 3$ the salinity of sea water" (Roseen et al. 2009). The worsening settling performance due to high chloride concentration were also observed in other studies as well(Rommel and Helmreich 2018; Adamsson and Bergdahl 2006). The altered settling pattern may be responsible the leaching, as there are insufficient studies on the impact of chloride on leaching of TSS, this may be a topic warrants further study.

Note that the spike in chloride concentration was observed in late winter as well (January 10, February 2, March 10 and March 14), but TSS reduction remained very high, which agrees with literature(Denich et al. 2013; Khan et al. 2012b; Roseen et al. 2009). This could suggest most of the finer particles accumulated in the soil during summer are leached out during the first few road salt wash-off events such that very little mobile fine particles remain in late winter. Further monitoring of TSS PSD in influent and effluent over the season may be required to support this hypothesis, lack of study was available on the effect of first application of salt.

Studies have suggested long term exposure to chloride may have an effect on the treatment performance of bioretention due to clogging (Denich et al. 2013). The result of the 2016 monitoring operation suggests that the particulate removal efficiency remains high (53\% for copper - $91 \%$ for lead removal) compare to the performance of traditional bioretention systems, even after eight years of operation. This could suggest exposure to road salt has no long-term effect on the metal performance.

\section{Metal Concentration Reduction}

Metals monitored in the operation include aluminum, copper, iron, lead, nickel, and zinc. 
The soil cell significantly reduced the concentration of the metals with a percentage reduction range from $61 \%$ for nickel up to $91 \%$ for lead. The distribution for influent and effluent total concentrations (dissolved and non-dissolved) are shown in Figure 29 to Figure 34.

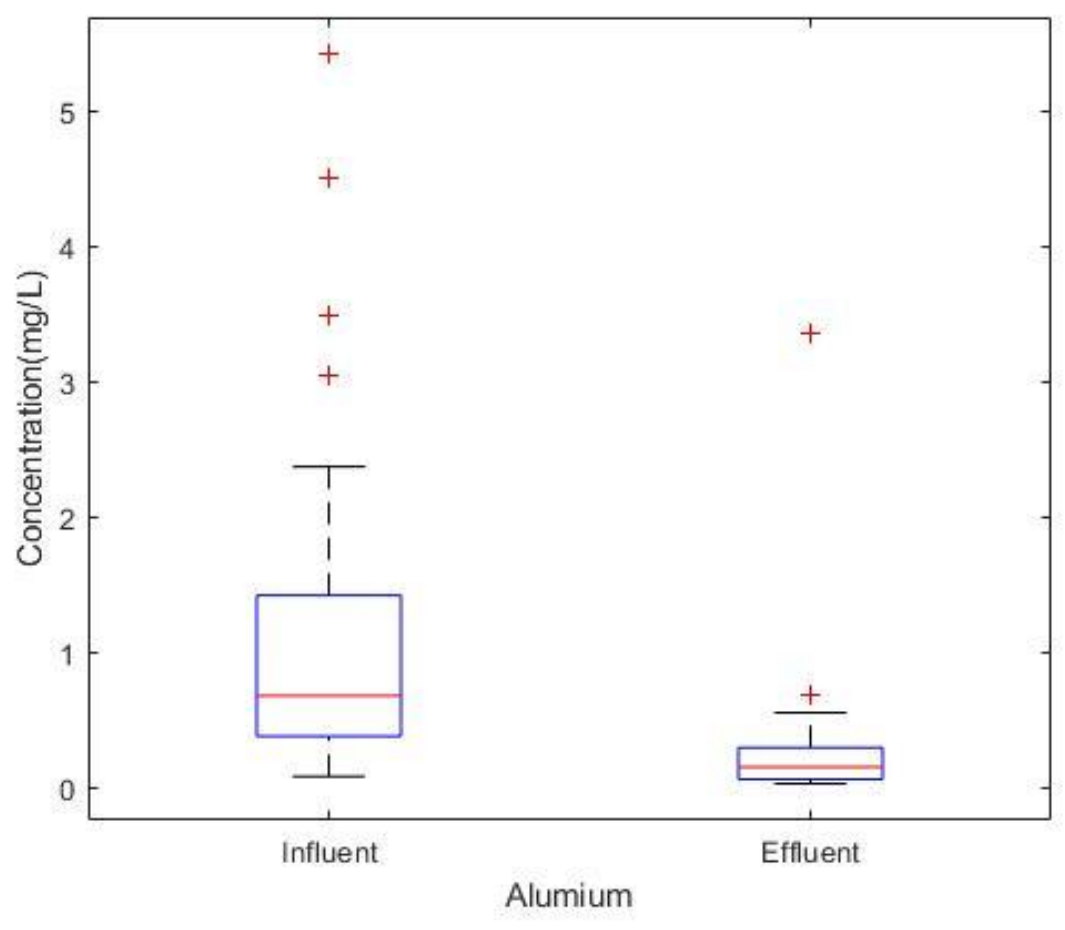

Figure 29. Aluminium Concentration Comparison 


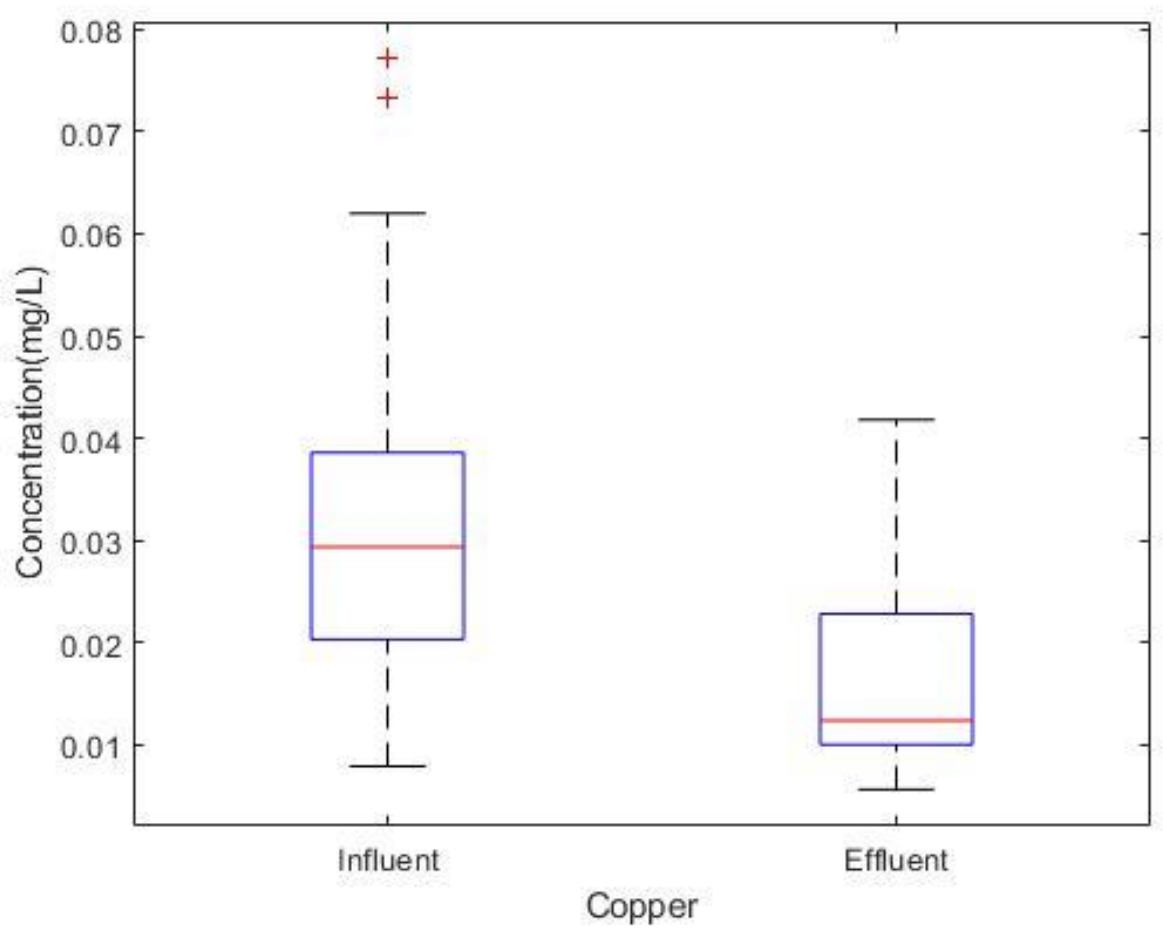

Figure 30. Copper Concentration Comparison

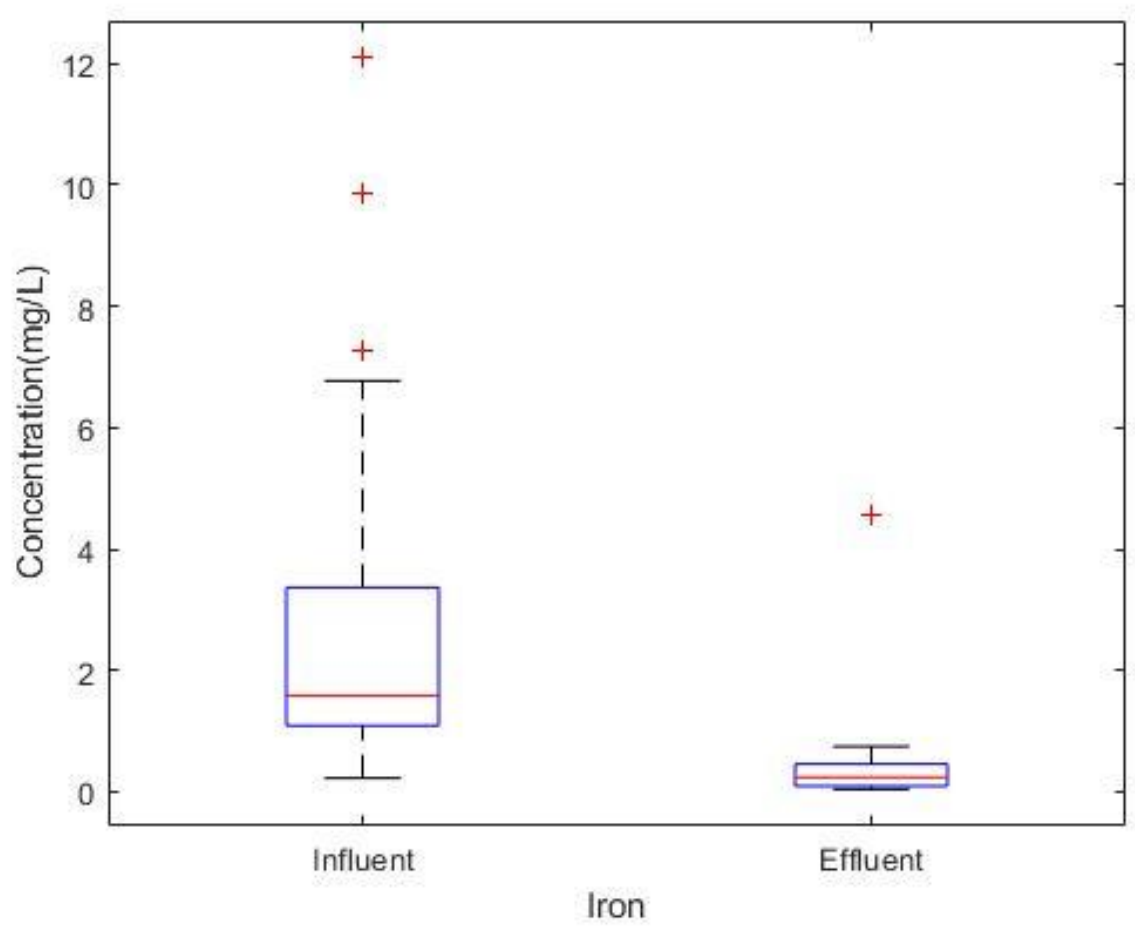

Figure 31. Iron Concentration Comparison 


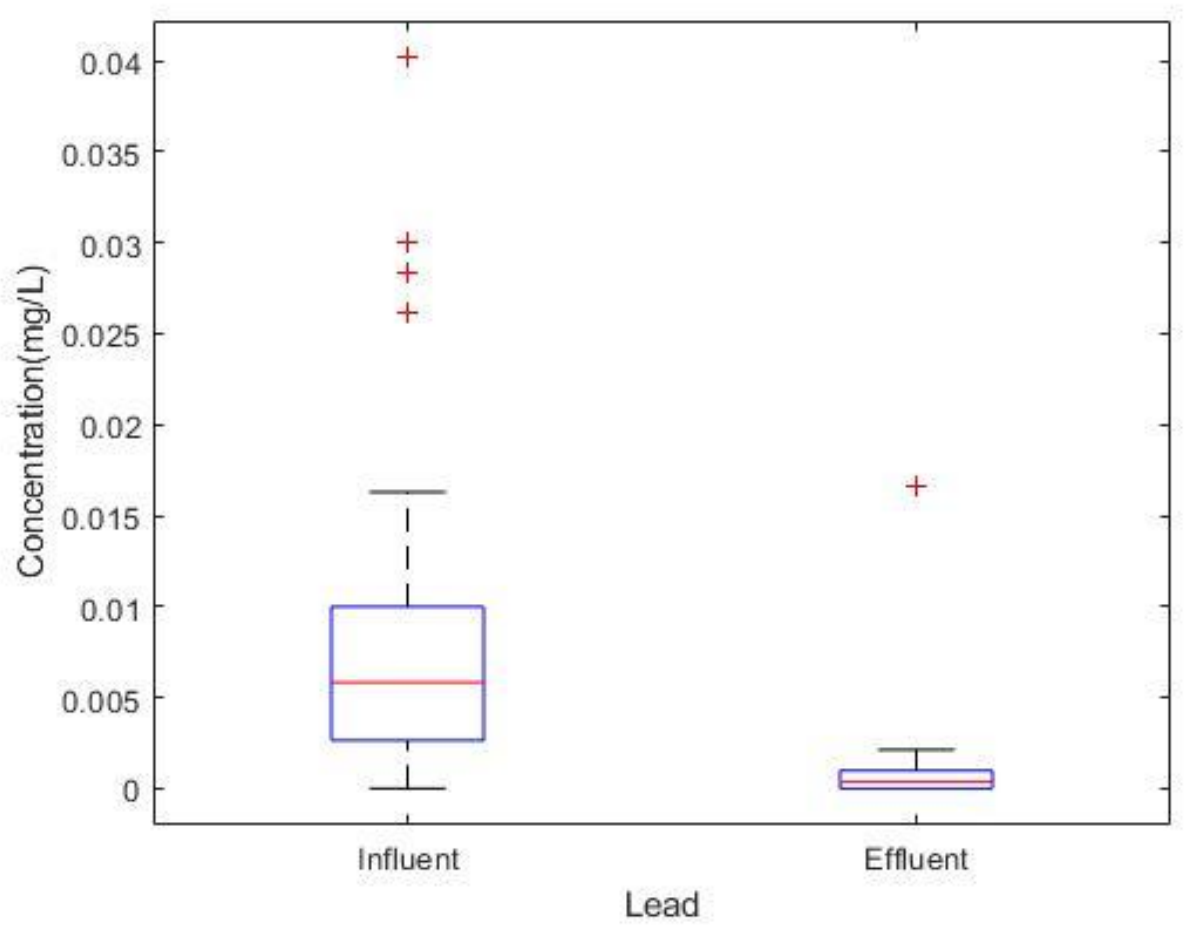

Figure 32. Total Lead Concentration Comparison

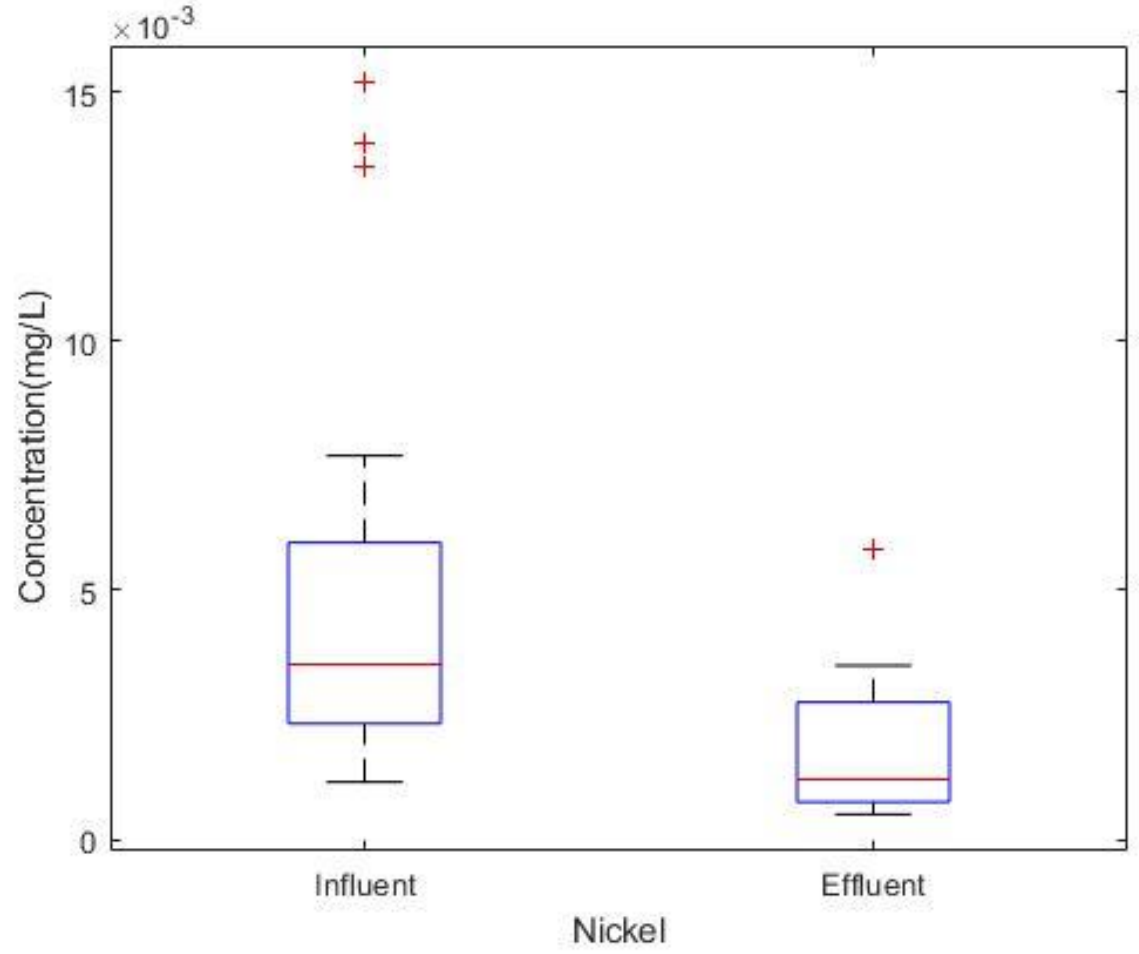

Figure 33. Total Nickel Concentration Comparison 


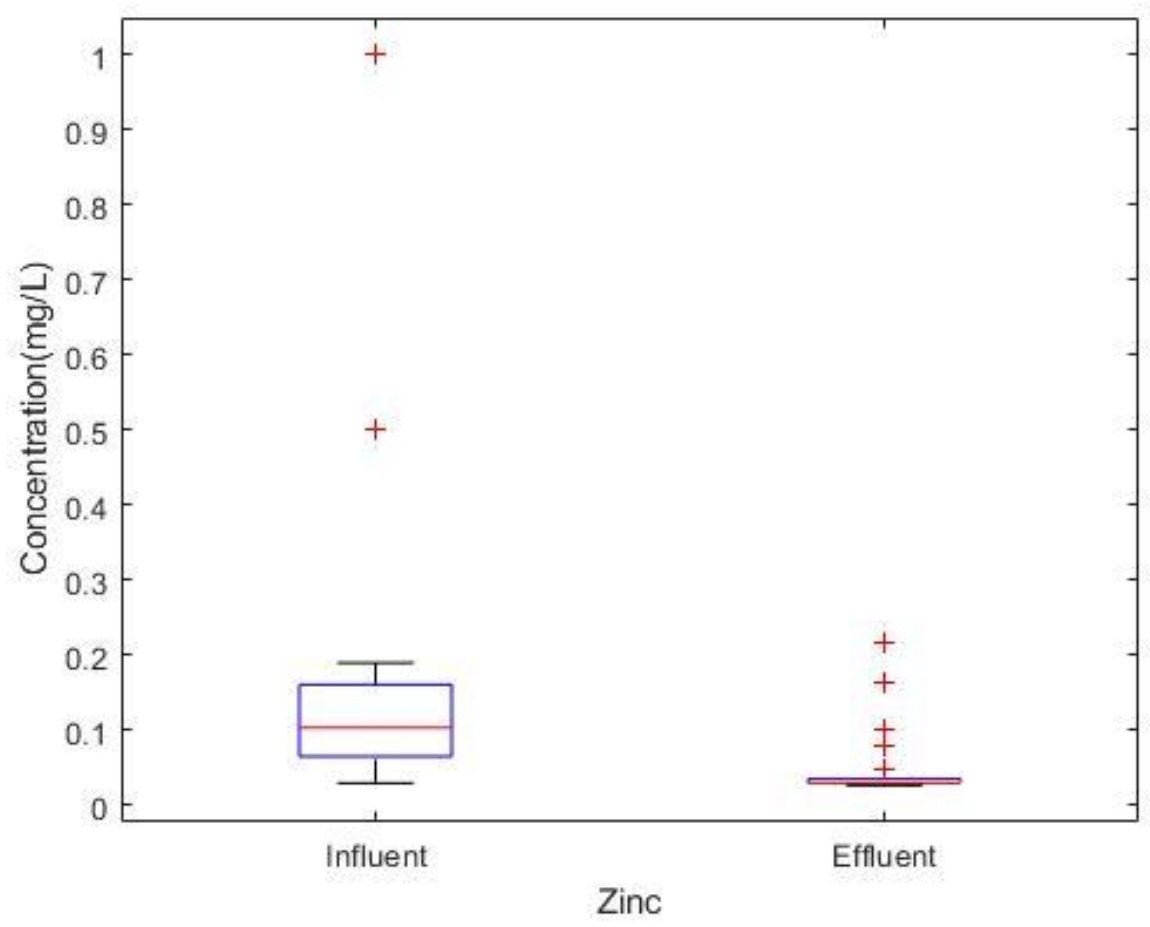

Figure 34. Zinc Concentration Comparison

The pair wise plot is plotted in Figure 35 to Figure 40 below:

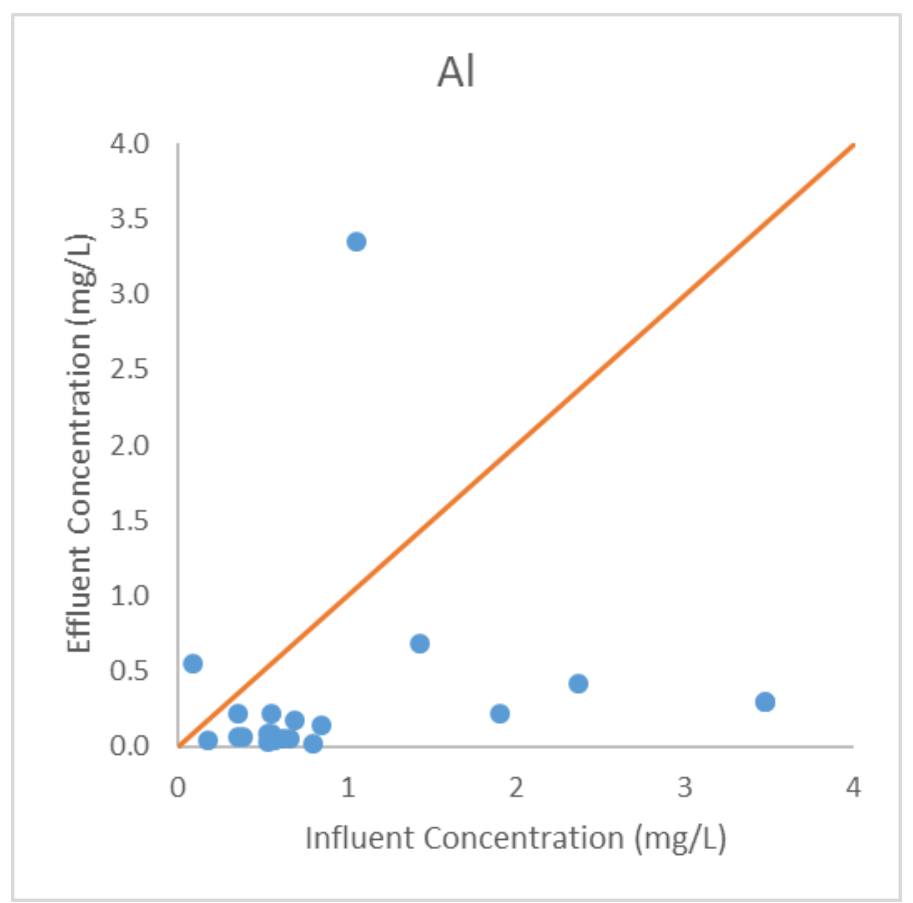

Figure 35. Pair Wise Comparison for Aluminum 


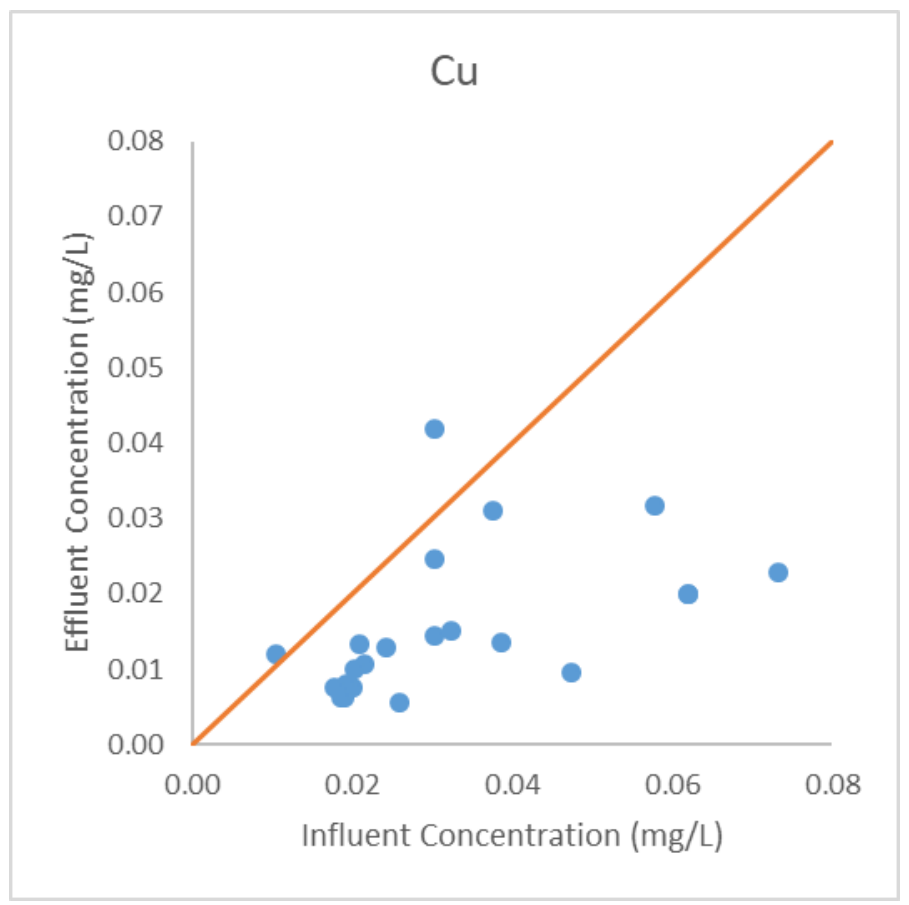

Figure 36. Pair Wise Comparison for Copper

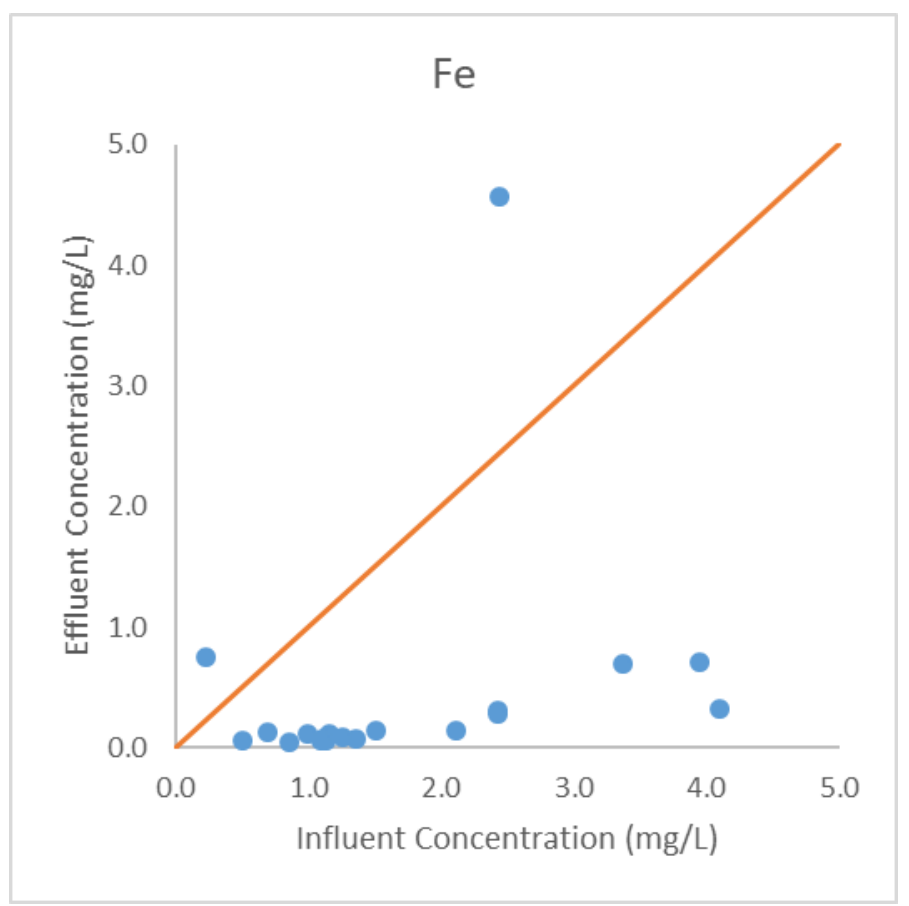

Figure 37. Pair Wise Comparison for Iron 


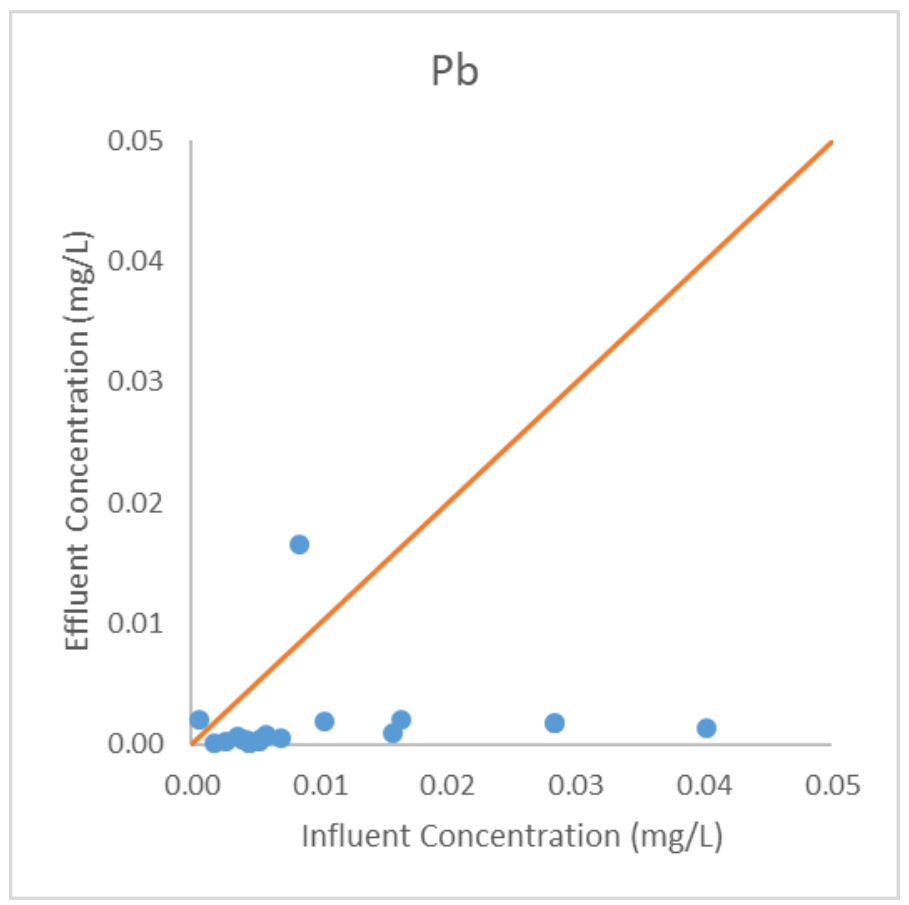

Figure 38. Pair Wise Comparison for Lead

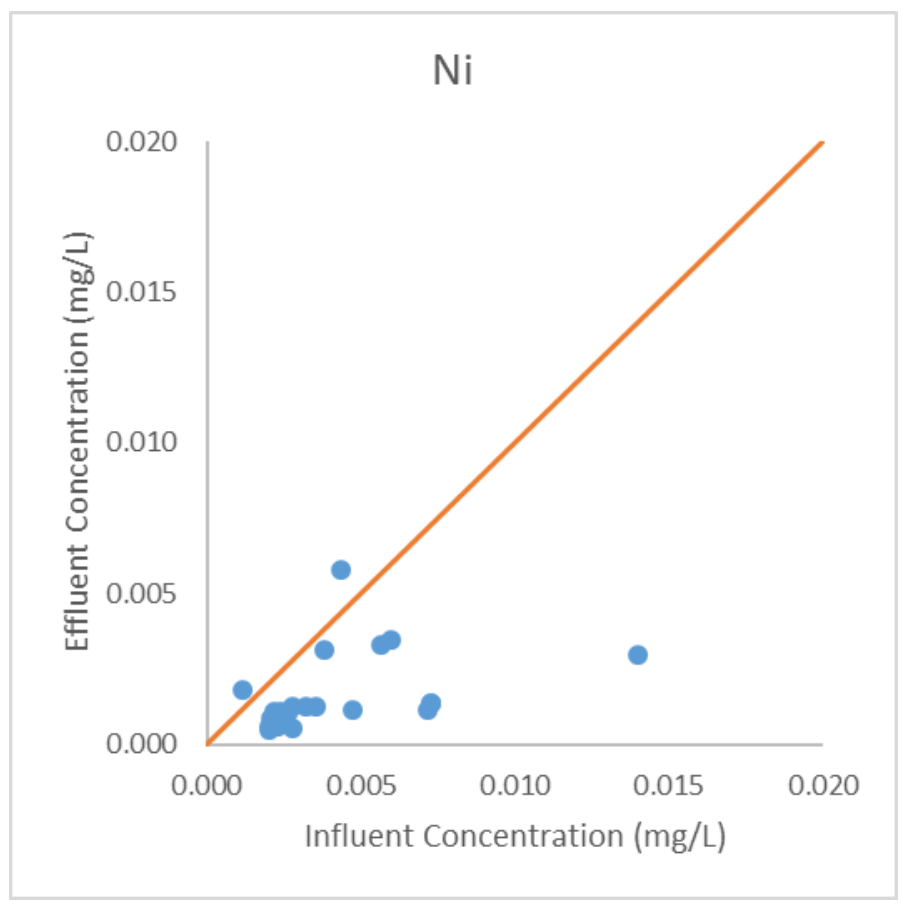

Figure 39. Pair Wise Comparison for Nickel 


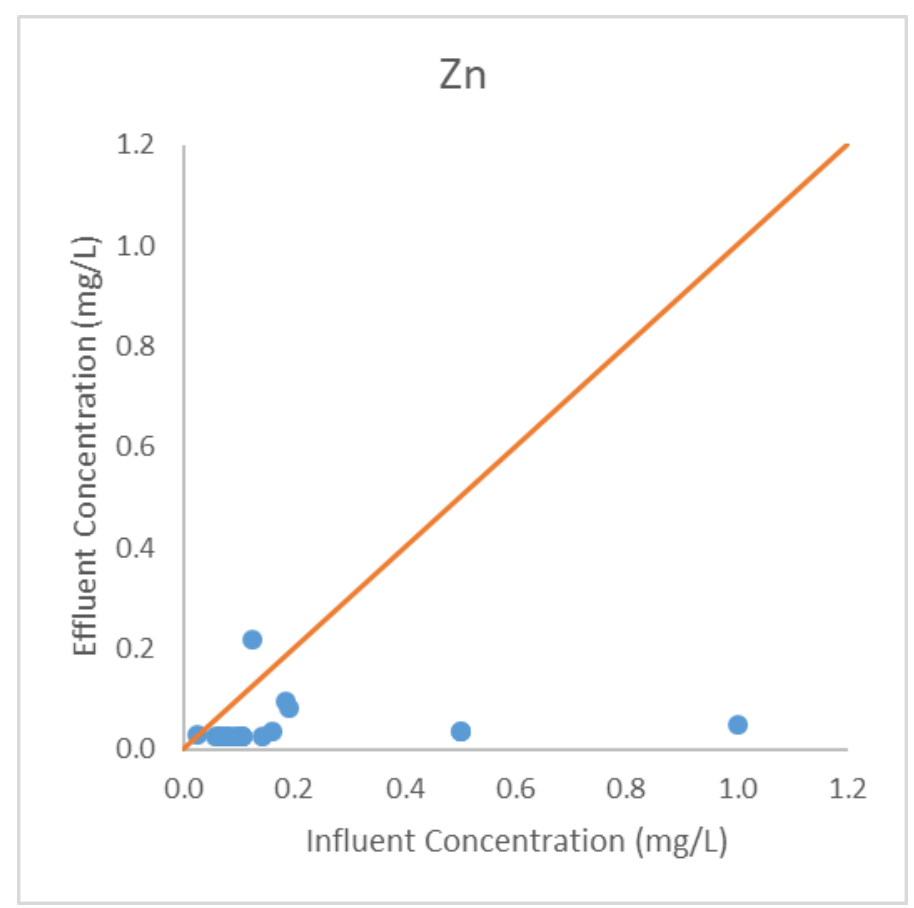

Figure 40. Pair Wise Comparison for Zinc

Coefficient of correlation between influent and effluent concentration are low for all metals and a summary is provided in Table 9 below:

Table 9. Coefficient of Correlation Between Influent and Effluent for Metal Concentration
\begin{tabular}{|l|l|l|l|l|l|l|}
\hline Metal & $\mathrm{Al}$ & $\mathrm{Cu}$ & $\mathrm{Fe}$ & $\mathrm{Pb}$ & $\mathrm{Ni}$ & $\mathrm{Zn}$ \\
\hline $\begin{array}{l}\text { Coefficient of } \\
\text { Correlation }\left(\mathbf{R}^{\mathbf{2}}\right)\end{array}$ & -0.07 & 0.18 & 0.016 & -0.061 & 0.026 & -0.49 \\
\hline
\end{tabular}

Influent and effluent concentration shows very little correlation, this pattern is similar to that of the TSS. As discussed in previous literature, metal concentration has strong correlation with TSS (Loganathan et al. 2013), and effluent TSS concentration does not necessarily correlate to the influent (Khan et al. 2012a). The effluent concentration was observed to increase during two events for all metals. The temporal distribution is plotted in Figure 41 to Figure 46 below: 


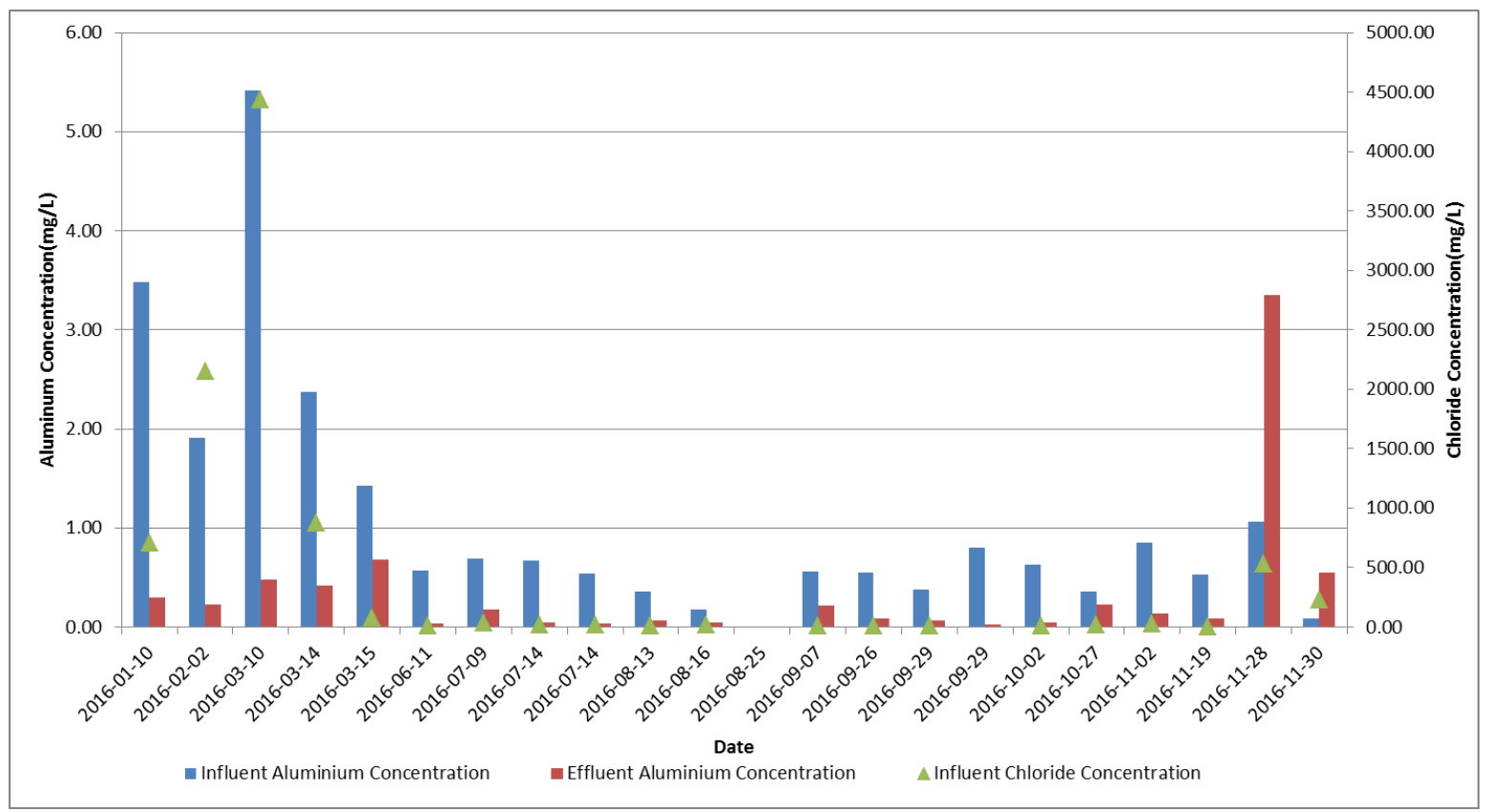

Figure 41. Influent and Effluent Aluminum Concentration vs Influent Chloride Concentration

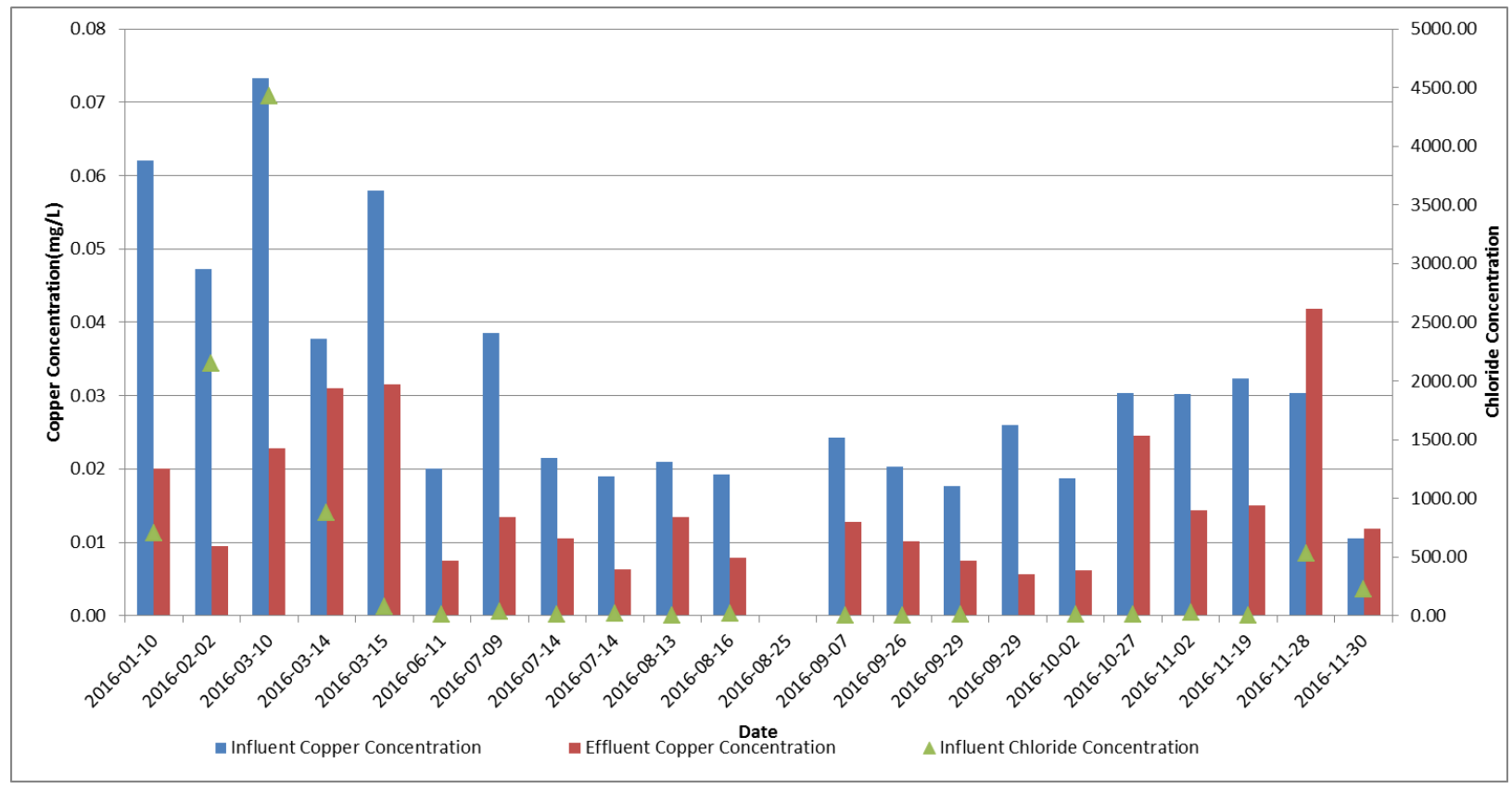

Figure 42. Influent and Effluent Copper Concentration vs Influent Chloride Concentration 


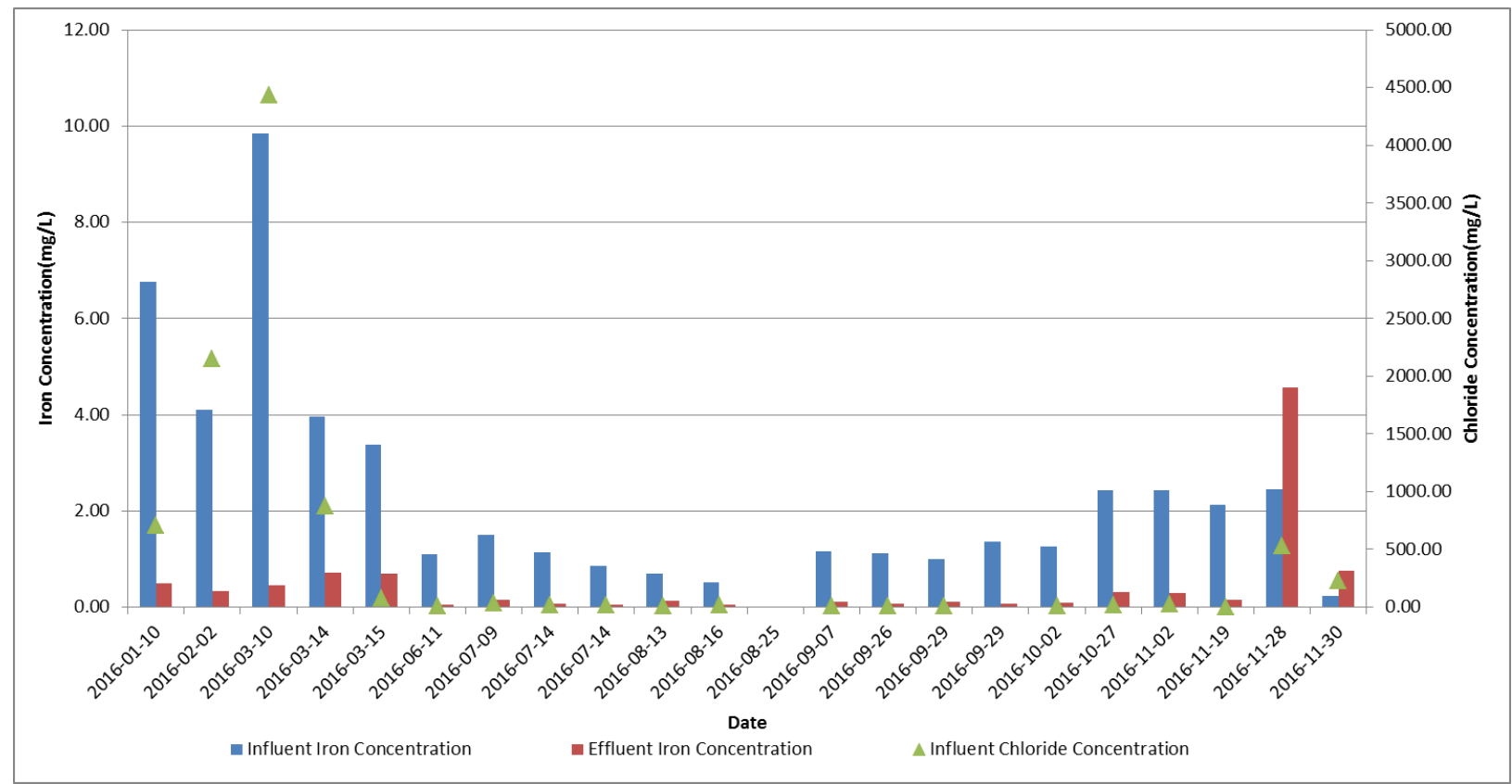

Figure 43. Influent and Effluent Iron Concentration vs Influent Chloride Concentration

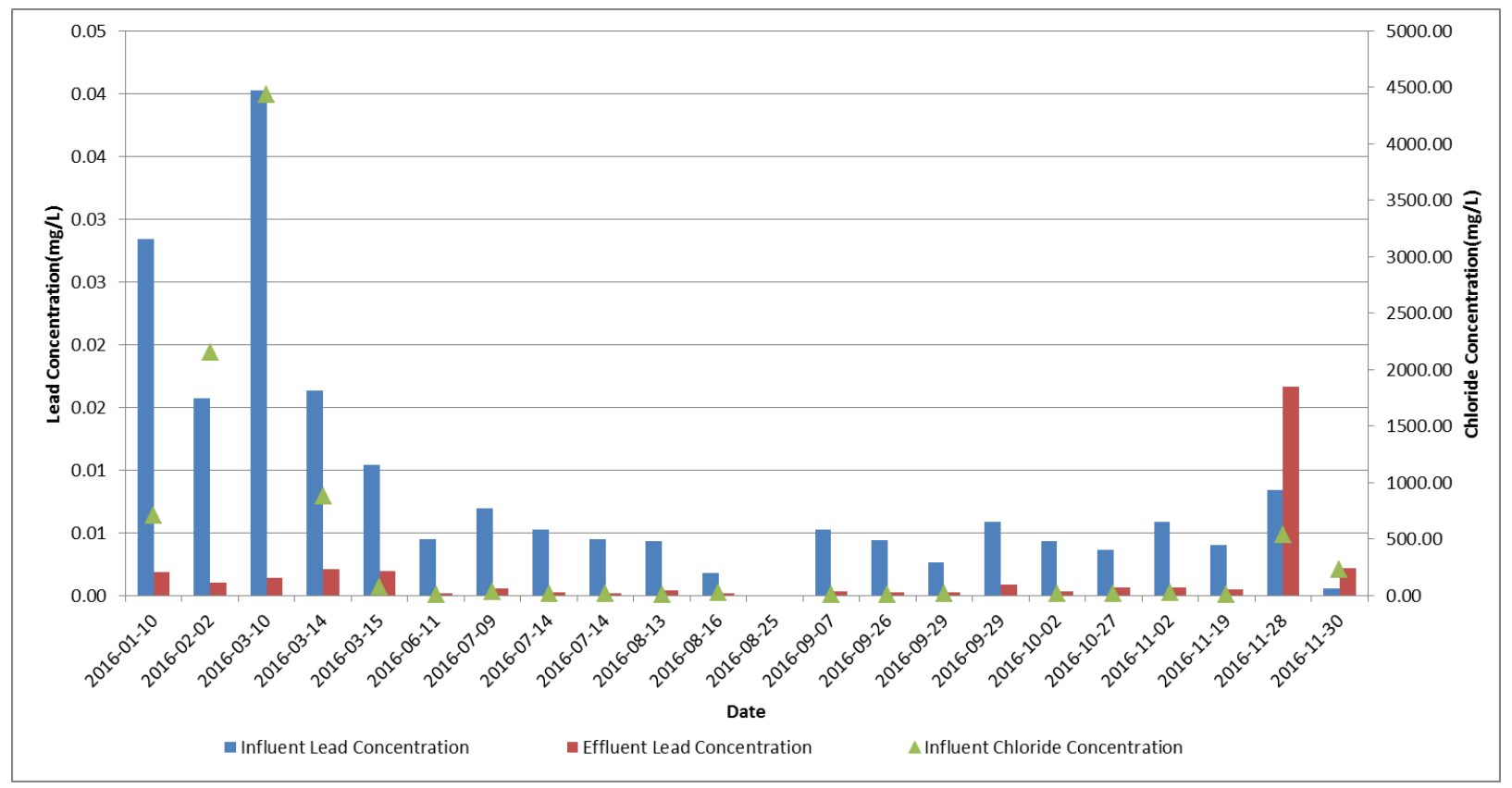

Figure 44. Influent and Effluent Lead Concentration vs Influent Chloride Concentration 


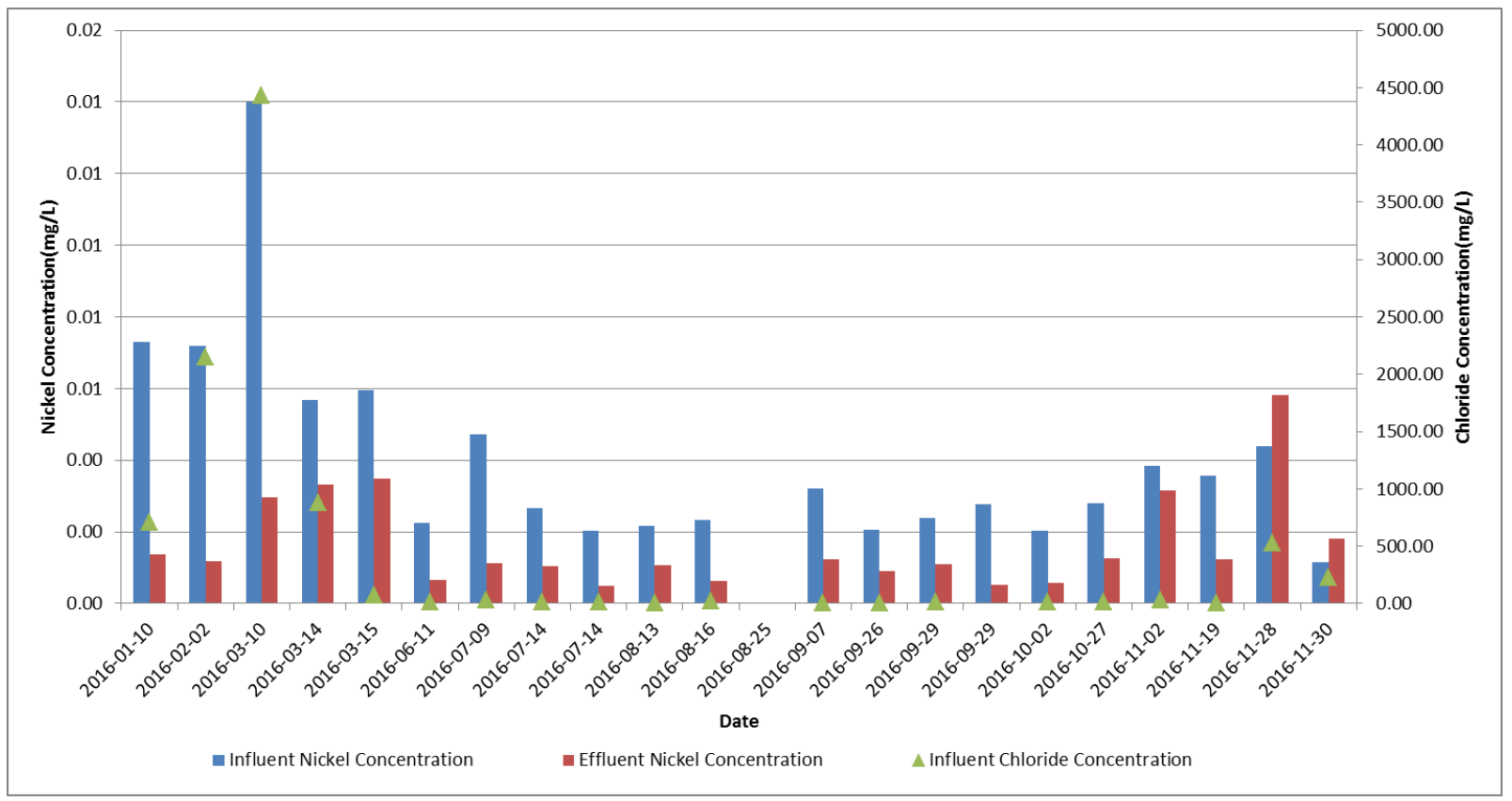

Figure 45. Influent and Effluent Nickel Concentration vs Influent Chloride Concentration

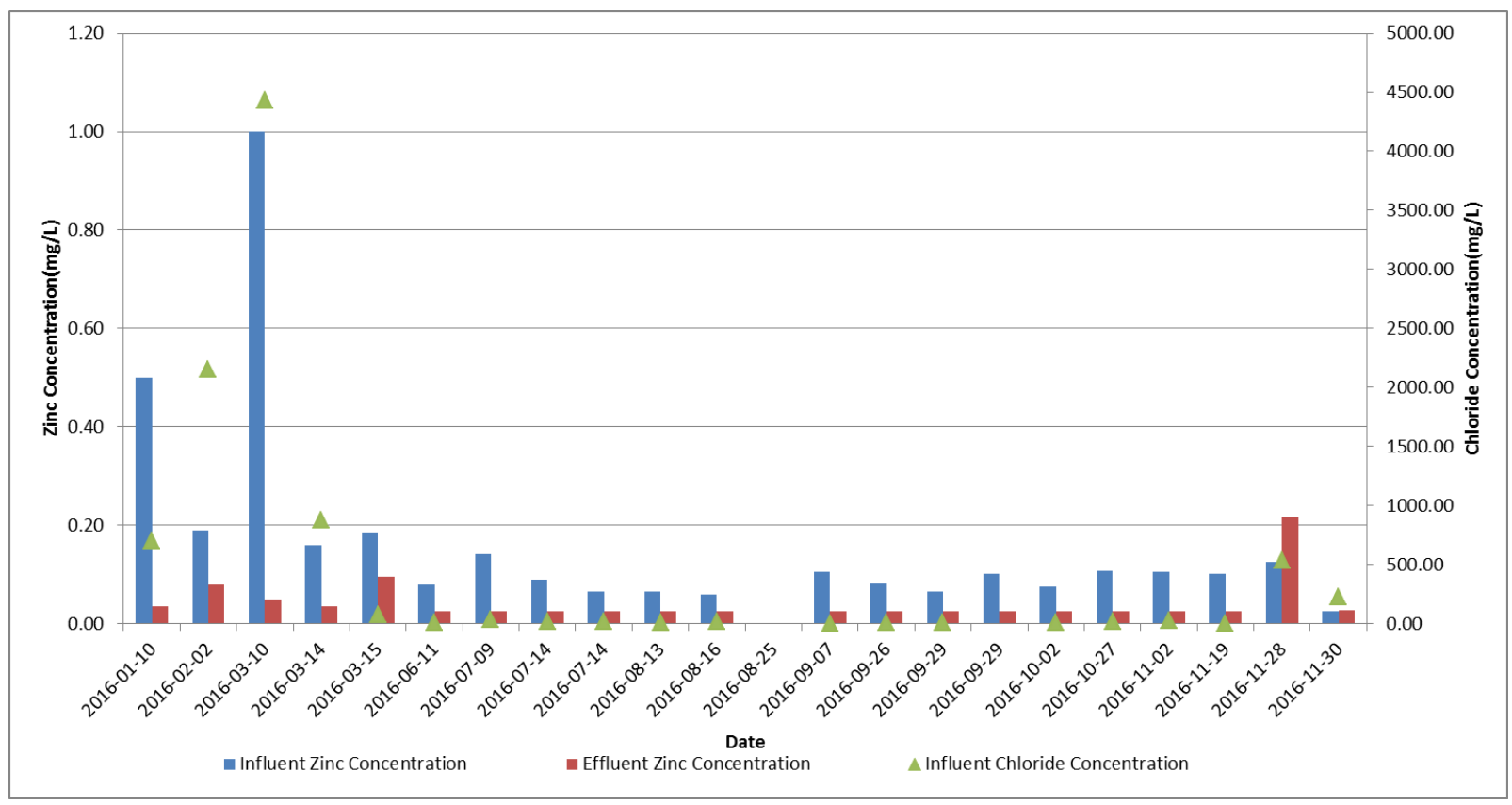

Figure 46. Influent and Effluent Zinc Concentration vs Influent Chloride Concentration 
The pattern of the metal leaching is similar to the TSS, the leaching did coincide with the first road salt wash-off events and the TSS leaching events on November 28 and November 30 .

Concentration reduction was achieved for rest of the year.

The concentration for dissolved metal reduction, pairwise comparisons are plotted in Figure 47 to Figure 51 below:

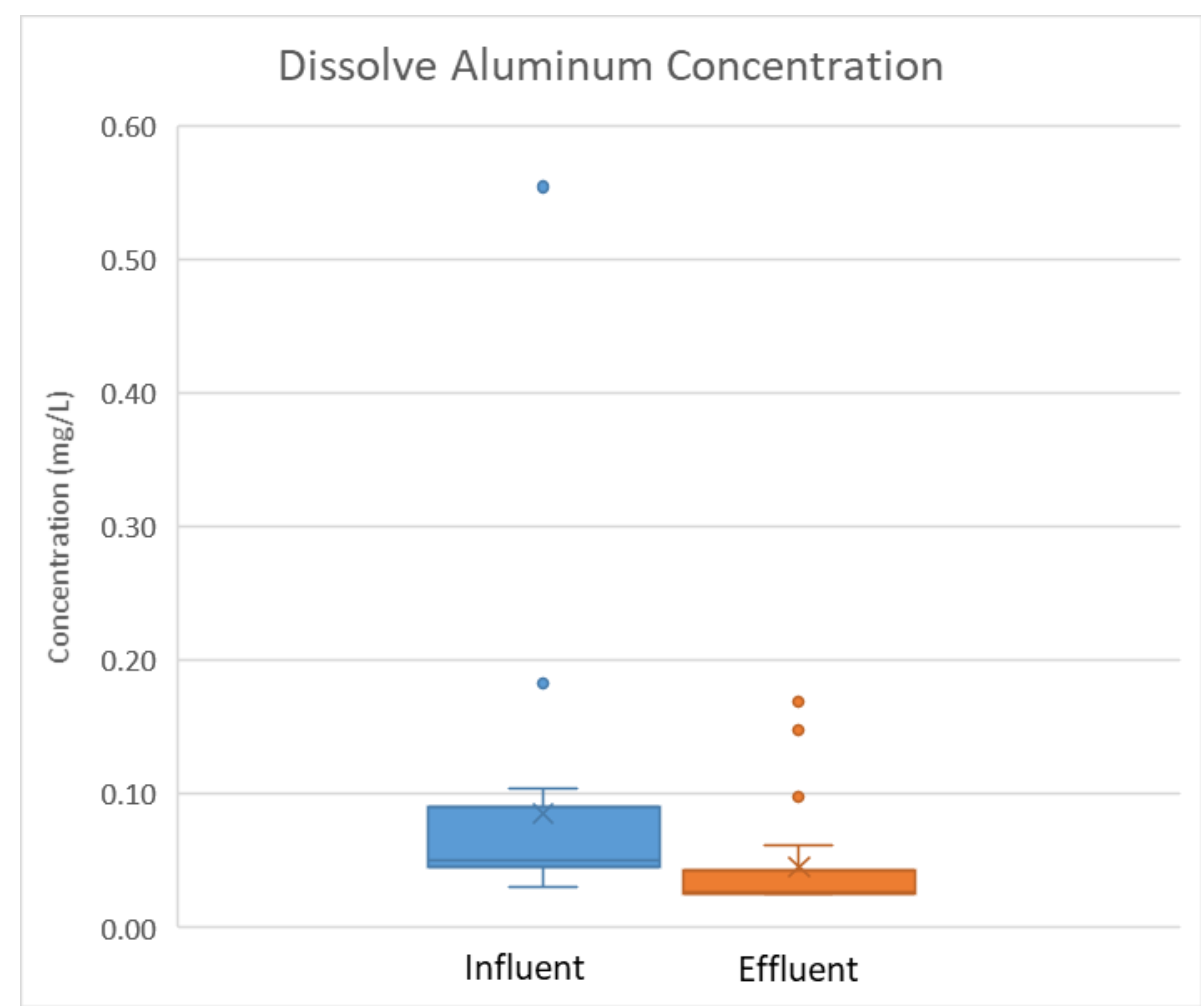

Figure 47. Dissolved Aluminum Concentration Comparison 


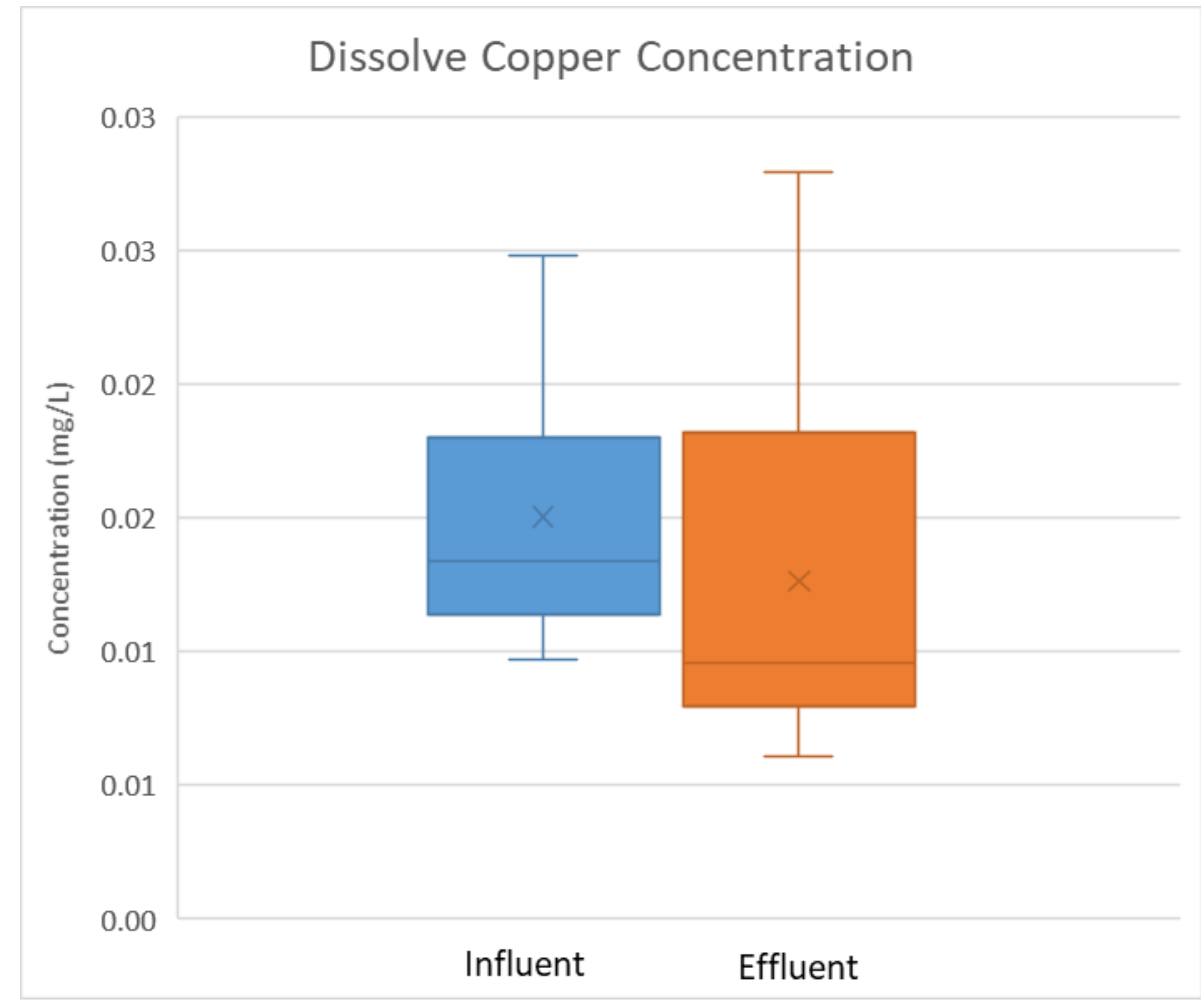

Figure 48. Dissolved Copper Concentration Comparison

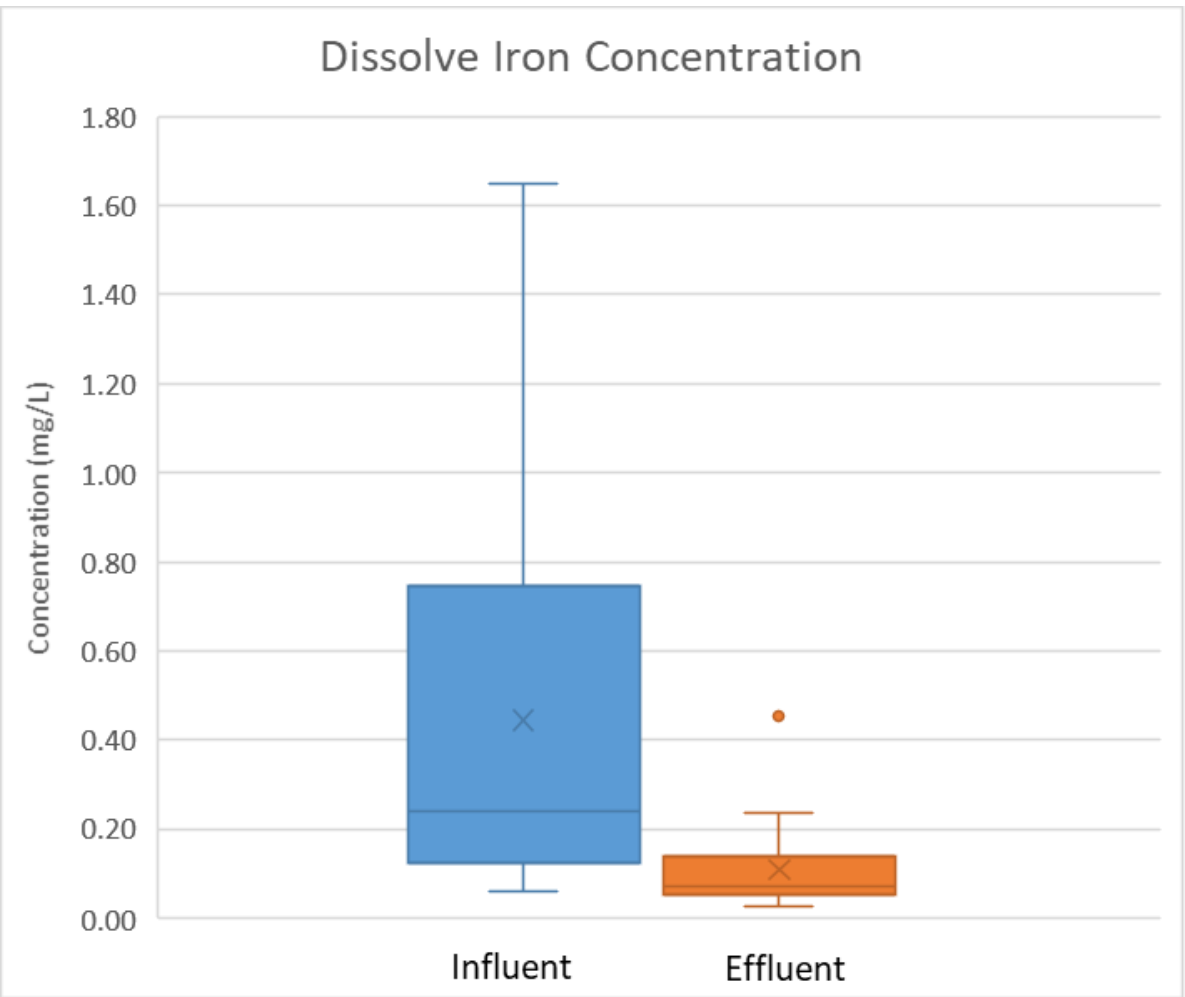

Figure 49. Dissolved Iron Concentration Comparison 


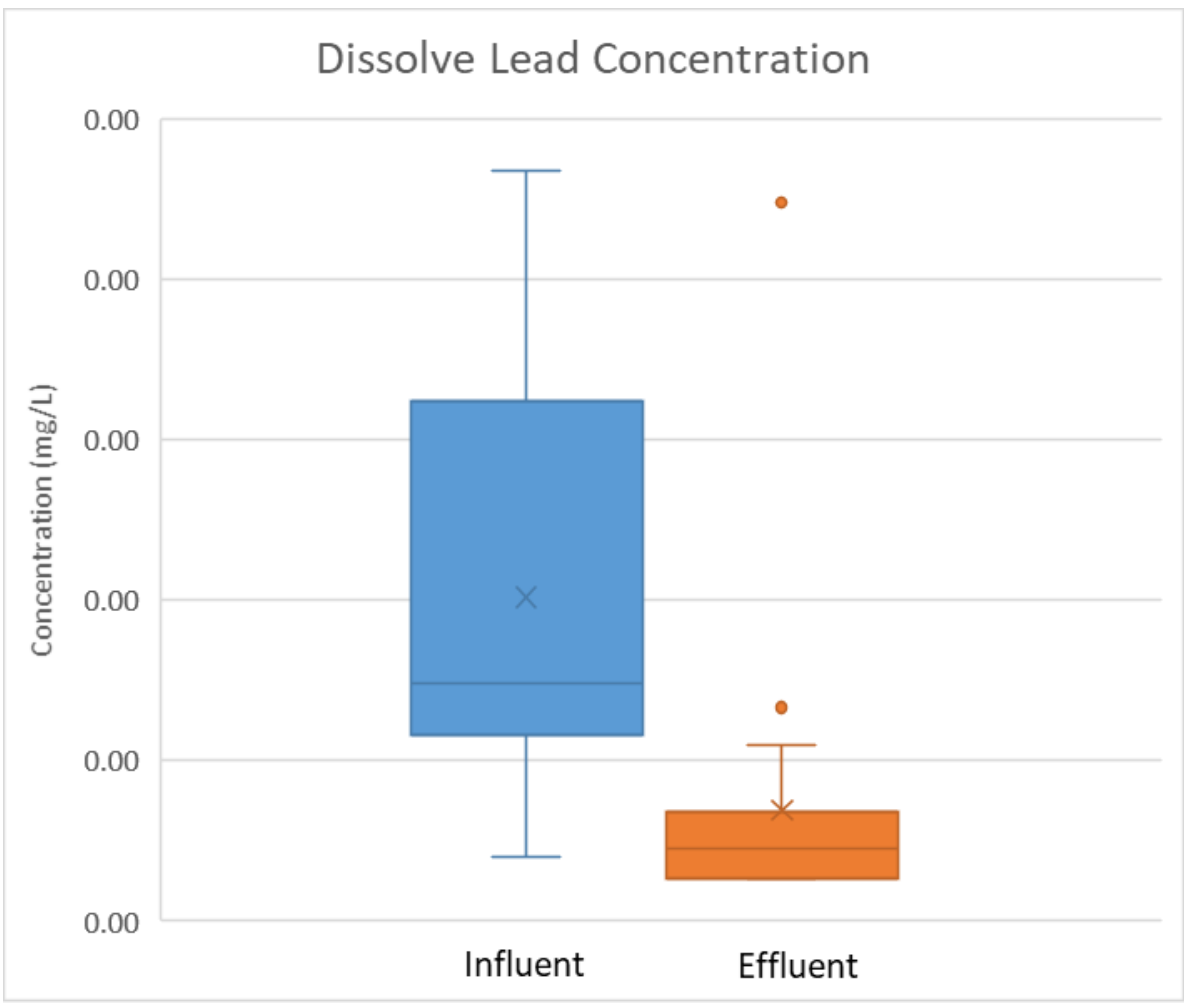

Figure 50. Dissolved Lead Concentration Comparison

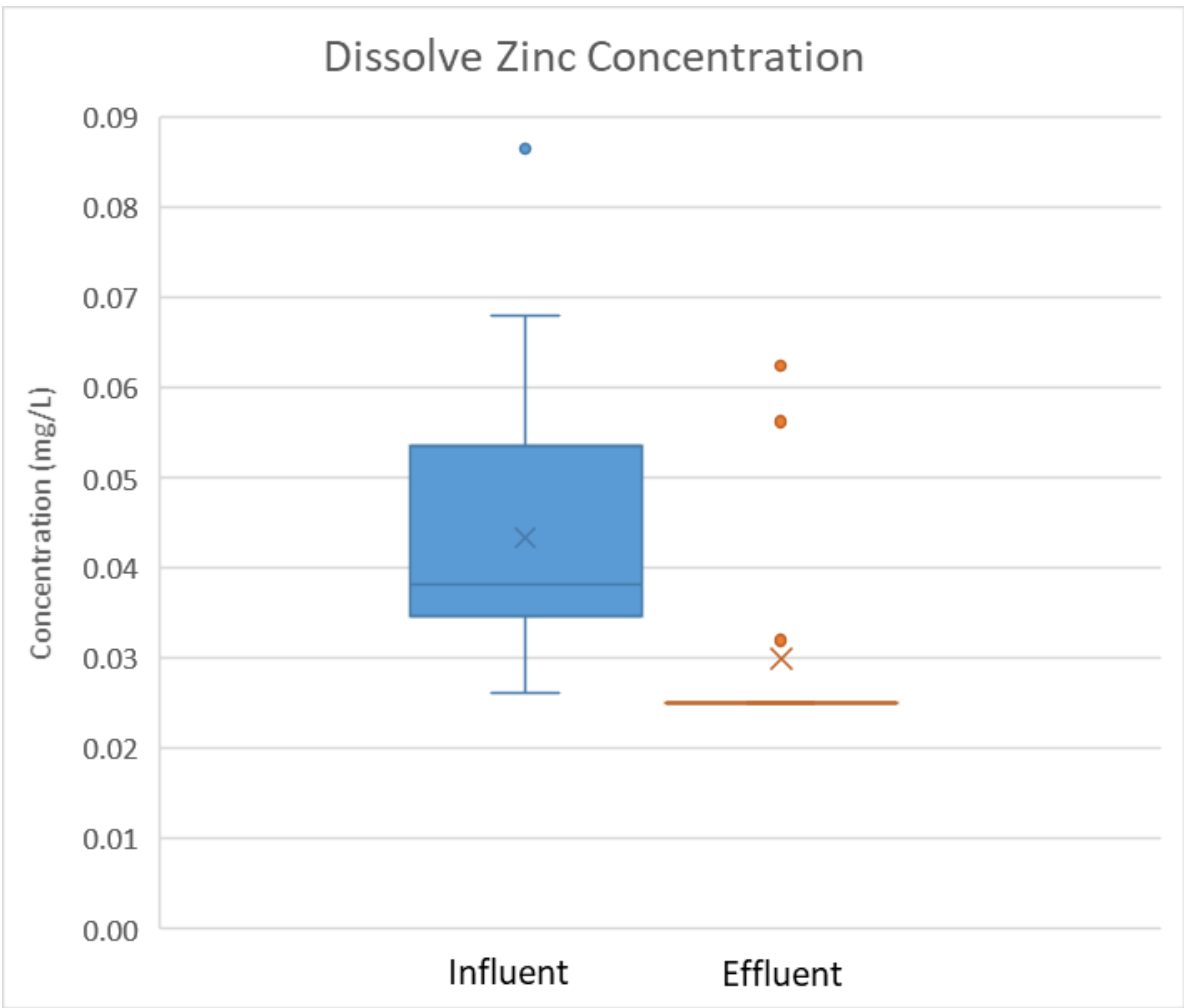

Figure 51. Dissolved Zinc Concentration Comparison 
The concentration reduction summary is provided in Table 10 below: 
Table 10. Statistical Summary of Influent and Effluent Dissolved Metal Concentration

\begin{tabular}{|c|c|c|c|c|c|c|c|c|c|c|c|c|c|c|}
\hline \multirow[b]{2}{*}{ Pollutants } & \multicolumn{6}{|c|}{ Influent Concentration } & \multicolumn{6}{|c|}{ Effluent Concentration } & & \\
\hline & $\%<\mathrm{dl}$ & Min & $\operatorname{Max}$ & Mean & Median & St.Dev & $\%<\mathrm{dl}$ & Min & Max & Mean & Median & St.Dev & $\begin{array}{l}\text { Median Con } \\
\text { Reduction \% }\end{array}$ & $\begin{array}{c}\text { Significant? } \\
(\alpha<0.05)\end{array}$ \\
\hline $\begin{array}{c}\mathrm{Al} \\
(\mathrm{mg} / \mathrm{L})\end{array}$ & $0 \%$ & $\begin{array}{c}3.01 \mathrm{E} \\
-02 \\
\end{array}$ & $\begin{array}{l}5.54 \\
\text { E-01 } \\
\end{array}$ & $\begin{array}{c}8.52 \mathrm{E} \\
-02 \\
\end{array}$ & $\begin{array}{c}5.03 \mathrm{E}- \\
02\end{array}$ & $\begin{array}{c}1.08 \mathrm{E}- \\
01\end{array}$ & $48 \%$ & $\begin{array}{c}2.50 \mathrm{E}- \\
02 \\
\end{array}$ & $\begin{array}{c}1.69 \mathrm{E}- \\
01 \\
\end{array}$ & $\begin{array}{c}4.48 \mathrm{E}- \\
02 \\
\end{array}$ & $\begin{array}{c}2.57 \mathrm{E}- \\
02\end{array}$ & $\begin{array}{c}3.96 \mathrm{E}- \\
02 \\
\end{array}$ & $47 \%$ & $\begin{array}{c}\text { No } \\
\mathrm{P}=0.10\end{array}$ \\
\hline $\begin{array}{c}\mathrm{Cu} \\
(\mathrm{mg} / \mathrm{L})\end{array}$ & $0 \%$ & $\begin{array}{c}9.71 \mathrm{E} \\
-03 \\
\end{array}$ & $\begin{array}{l}2.48 \\
\text { E-02 } \\
\end{array}$ & $\begin{array}{c}1.50 \mathrm{E} \\
-02 \\
\end{array}$ & $\begin{array}{c}1.34 \mathrm{E}- \\
02\end{array}$ & $\begin{array}{c}4.57 \mathrm{E}- \\
03 \\
\end{array}$ & $43 \%$ & $\begin{array}{c}6.03 \mathrm{E}- \\
03 \\
\end{array}$ & $\begin{array}{c}2.79 \mathrm{E}- \\
02 \\
\end{array}$ & $\begin{array}{c}1.26 \mathrm{E}- \\
02 \\
\end{array}$ & $\begin{array}{c}9.54 \mathrm{E}- \\
03\end{array}$ & $\begin{array}{c}6.50 \mathrm{E}- \\
03 \\
\end{array}$ & $53 \%$ & $\begin{array}{c}\text { No } \\
\mathrm{P}=0.06\end{array}$ \\
\hline $\begin{array}{c}\mathrm{Fe} \\
(\mathrm{mg} / \mathrm{L})\end{array}$ & $0 \%$ & $\begin{array}{c}5.83 \mathrm{E} \\
-02 \\
\end{array}$ & $\begin{array}{c}1.65 \\
E+00 \\
\end{array}$ & $\begin{array}{c}4.44 \mathrm{E} \\
-01 \\
\end{array}$ & $\begin{array}{c}2.41 \mathrm{E}- \\
01\end{array}$ & $\begin{array}{c}4.54 \mathrm{E}- \\
01 \\
\end{array}$ & $0 \%$ & $\begin{array}{c}2.50 \mathrm{E}- \\
02 \\
\end{array}$ & $\begin{array}{c}4.53 \mathrm{E}- \\
01 \\
\end{array}$ & $\begin{array}{c}1.09 \mathrm{E}- \\
01 \\
\end{array}$ & $\begin{array}{c}\text { 7.29E- } \\
02\end{array}$ & $\begin{array}{c}9.50 \mathrm{E}- \\
02 \\
\end{array}$ & $90 \%$ & $\begin{array}{c}\text { Yes } \\
\mathrm{P}=0.001 \\
\end{array}$ \\
\hline $\begin{array}{c}\mathrm{Pb} \\
(\mathrm{mg} / \mathrm{L})\end{array}$ & $0 \%$ & $\begin{array}{c}1.99 \mathrm{E} \\
-04 \\
\end{array}$ & $\begin{array}{l}2.34 \\
\text { E-03 }\end{array}$ & $\begin{array}{c}1.01 \mathrm{E} \\
-03 \\
\end{array}$ & $\begin{array}{c}\text { 7.37E- } \\
04\end{array}$ & $\begin{array}{c}\text { 6.61E- } \\
04\end{array}$ & $26 \%$ & $\begin{array}{c}1.30 \mathrm{E}- \\
04\end{array}$ & $\begin{array}{c}2.24 \mathrm{E}- \\
03 \\
\end{array}$ & $\begin{array}{c}3.42 \mathrm{E}- \\
04 \\
\end{array}$ & $\begin{array}{c}2.24 \mathrm{E}- \\
04\end{array}$ & $\begin{array}{c}4.38 \mathrm{E}- \\
04 \\
\end{array}$ & $91 \%$ & $\begin{array}{c}\text { Yes, } \\
\mathrm{P}=0.000\end{array}$ \\
\hline $\begin{array}{c}\mathrm{Ni} \\
(\mu \mathrm{g} / \mathrm{L})\end{array}$ & $0 \%$ & $\begin{array}{c}1.59 \mathrm{E} \\
-03 \\
\end{array}$ & $\begin{array}{l}7.19 \\
\text { E-03 } \\
\end{array}$ & $\begin{array}{c}3.34 \mathrm{E} \\
-03 \\
\end{array}$ & $\begin{array}{c}2.98 \mathrm{E}- \\
03\end{array}$ & $\begin{array}{c}1.65 \mathrm{E}- \\
03 \\
\end{array}$ & $0 \%$ & $\begin{array}{c}9.47 \mathrm{E}- \\
04 \\
\end{array}$ & $\begin{array}{c}7.90 \mathrm{E}- \\
03 \\
\end{array}$ & $\begin{array}{c}2.14 \mathrm{E}- \\
03 \\
\end{array}$ & $\begin{array}{c}1.71 \mathrm{E}- \\
03\end{array}$ & $\begin{array}{c}1.45 \mathrm{E}- \\
03 \\
\end{array}$ & $61 \%$ & $\begin{array}{c}\text { Yes } \\
\mathrm{P}=0.002\end{array}$ \\
\hline $\begin{array}{c}\mathrm{Zn} \\
(\mathrm{mg} / \mathrm{L})\end{array}$ & $10 \%$ & $\begin{array}{c}2.61 \mathrm{E} \\
-02\end{array}$ & $\begin{array}{l}8.64 \\
\text { E-02 }\end{array}$ & $\begin{array}{c}4.34 \mathrm{E} \\
-02\end{array}$ & $\begin{array}{c}3.82 \mathrm{E}- \\
02\end{array}$ & $\begin{array}{c}1.55 \mathrm{E}- \\
02\end{array}$ & $83 \%$ & $\begin{array}{c}2.50 \mathrm{E}- \\
02\end{array}$ & $\begin{array}{c}6.28 \mathrm{E}- \\
02\end{array}$ & $\begin{array}{c}2.99 \mathrm{E}- \\
02\end{array}$ & $\begin{array}{c}2.50 \mathrm{E}- \\
02\end{array}$ & $\begin{array}{c}1.22 \mathrm{E}- \\
02\end{array}$ & $71 \%$ & $\begin{array}{c}\text { Yes } \\
\mathrm{P}=0.001\end{array}$ \\
\hline
\end{tabular}

List of abbreviations: $\mathrm{Al}=$ Aluminum, $\mathrm{BOD}=$ Biochemical Oxygen Demand, $\mathrm{Cl}=\mathrm{Chloride}, \mathrm{Cu}=$ Copper, $\mathrm{Fe}=\mathrm{Iron}, \mathrm{Pb}=\mathrm{Lead}$, $\mathrm{Ni}=$ Nickel, $\mathrm{NO}_{3}{ }^{-}=$Nitrate, $\mathrm{TP}=$ Total Phosphorus, $\mathrm{TSS}=$ Total Suspended Solids, $\mathrm{Zn}=\mathrm{Zinc}, \mathrm{dl}=$ detection limit, $\mathrm{Con}=$ Concentration, $\mathrm{E} \pm \mathrm{n}=10^{ \pm \mathrm{n}}$

Significance Level $=0.05$ 
The soil is shown to be very effective in reducing the concentration of dissolved iron( $91 \%$ concentration reduction), lead( $91 \%$ concentration reduction), nickel( $61 \%$ concentration reduction) and zinc( $71 \%$ concentration reduction).

Although the dissolved aluminum and copper are shown to be reduced, statistical analysis does not suggest it is significant, it is interesting to note nearly half of the effluent samples are under detection limit (48\% for aluminum, $43 \%$ for copper), while all influent for these two metals are above detection limit. This could suggest the concentration reduction for aluminum and copper are likely higher than what was measured.

Temporal distribution of influent and effluent concentration are plotted below in Figure 52 to Figure 56.

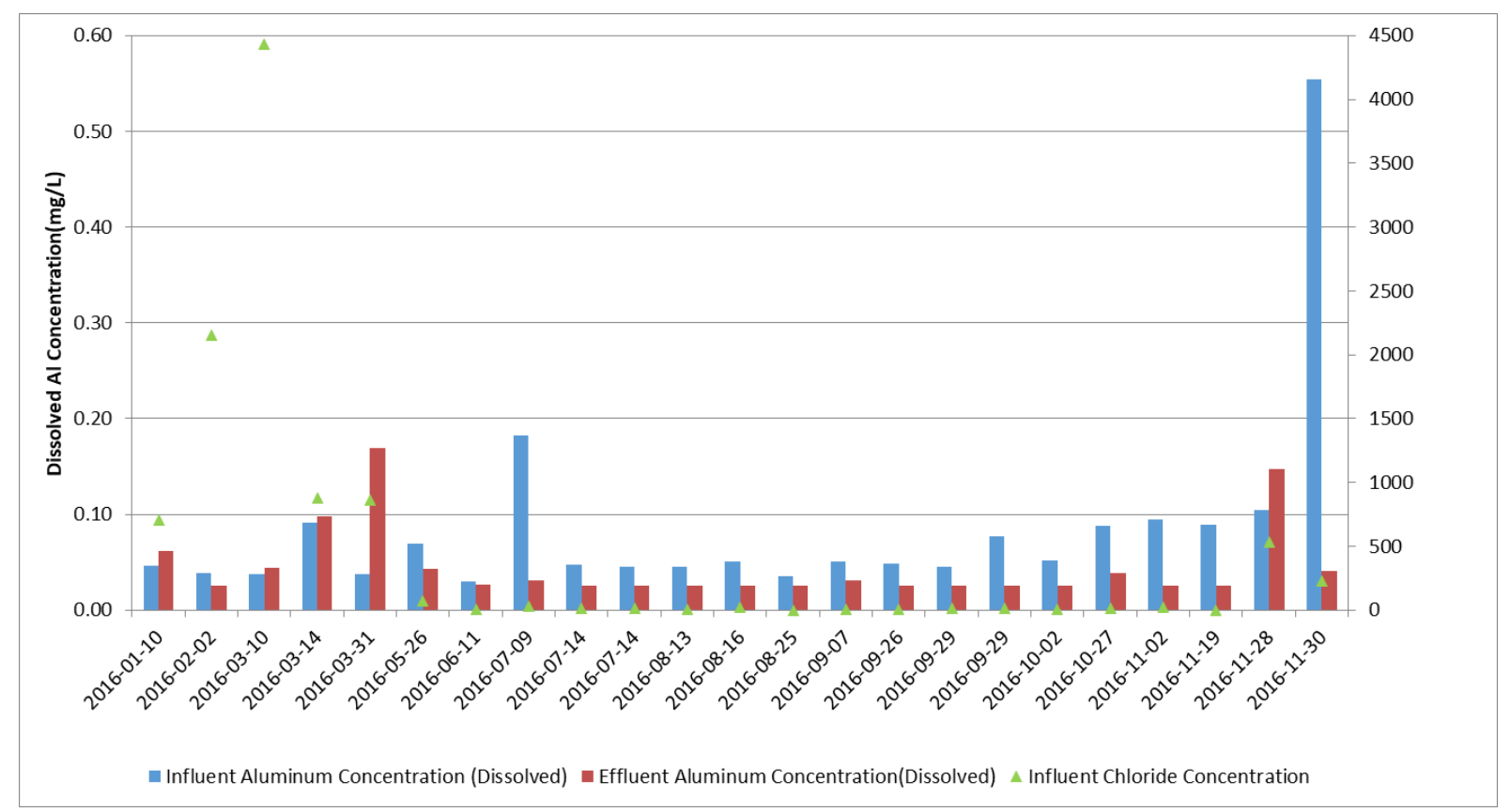

Figure 52. Influent and Effluent Dissolved Aluminum Concentration vs Influent Chloride Concentration 


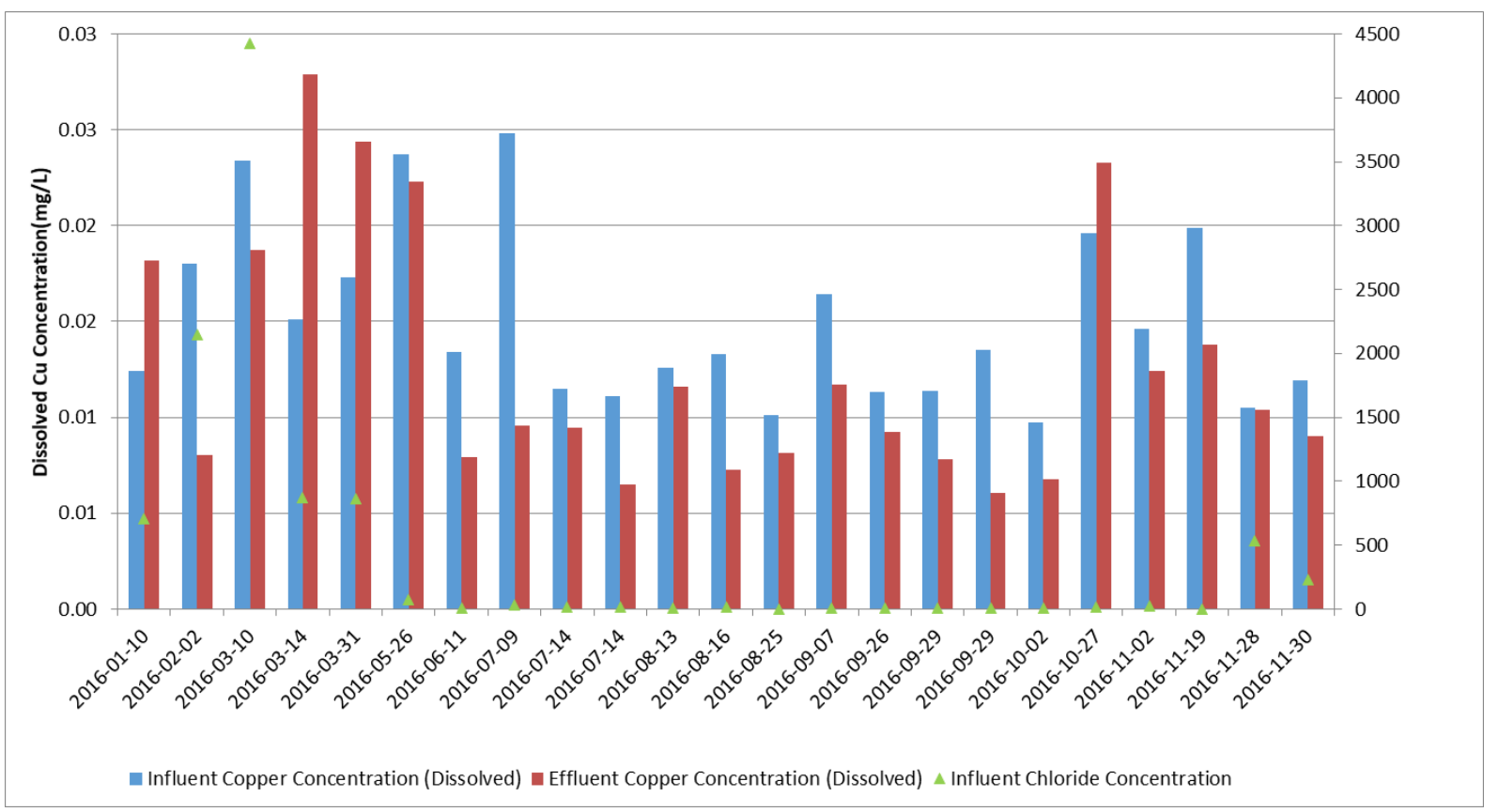

Figure 53. Influent and Effluent Dissolved Copper Concentration vs Influent Chloride Concentration

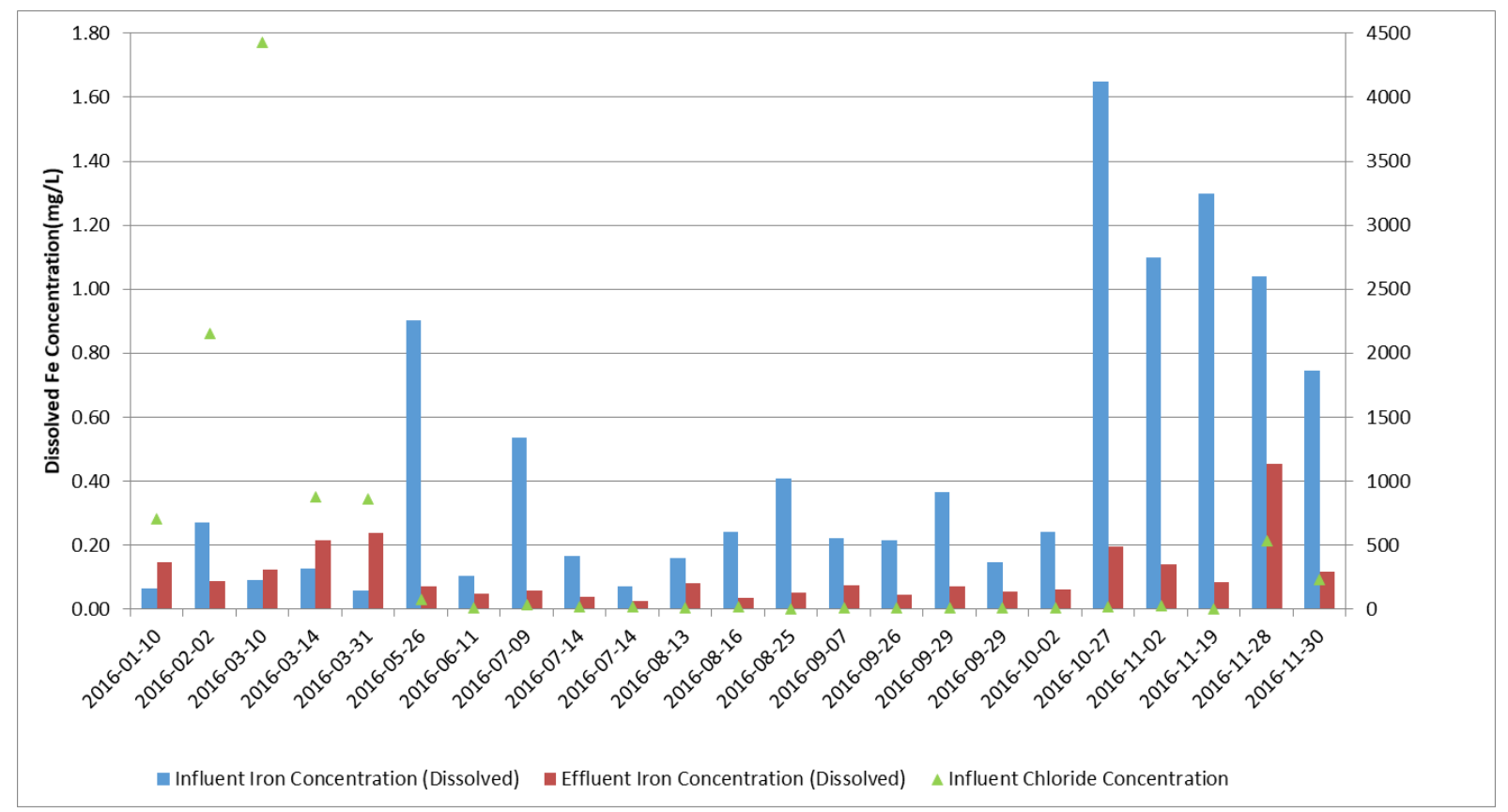

Figure 54. Influent and Effluent Dissolved Iron Concentration vs Influent Chloride Concentration 


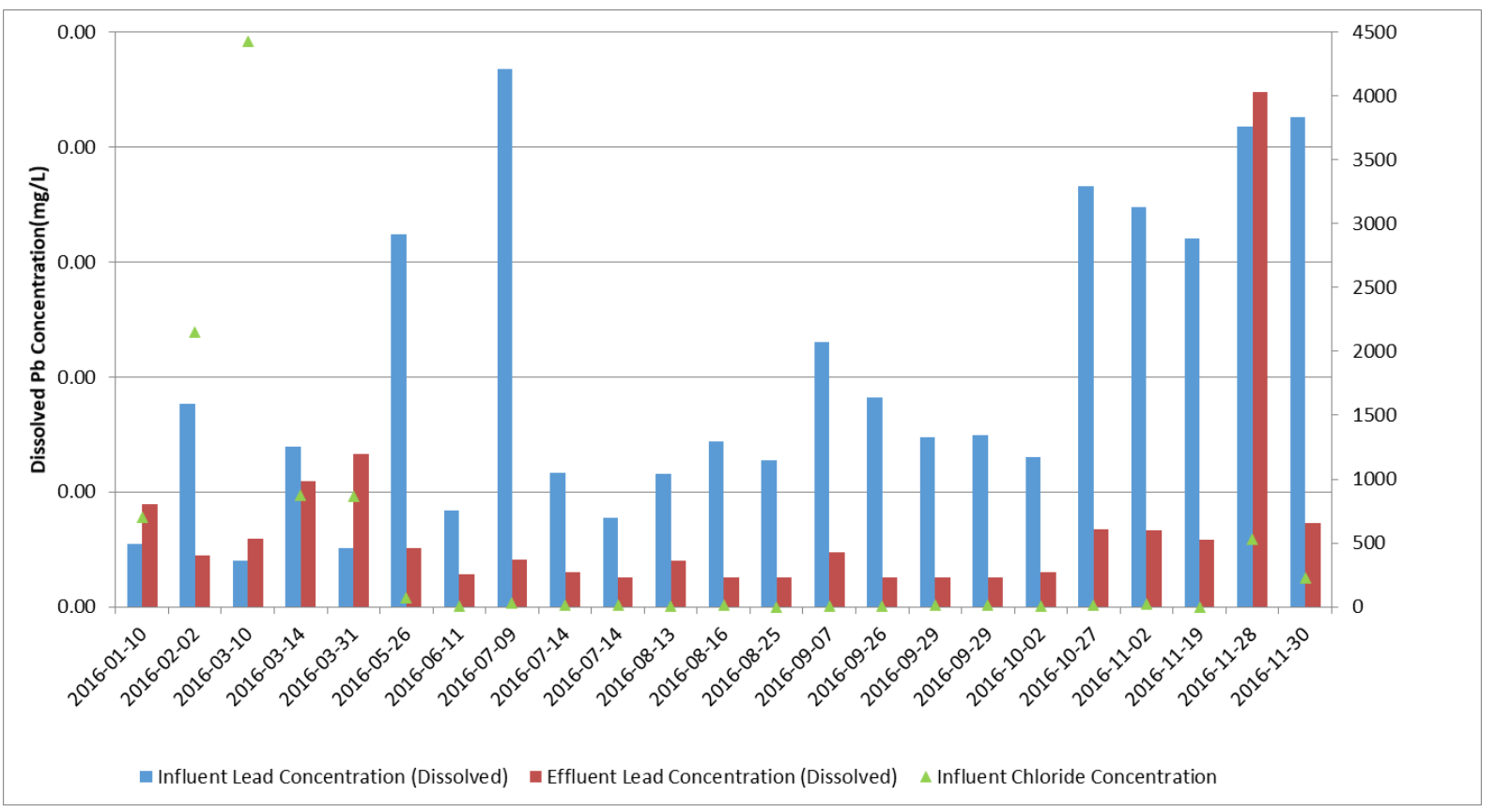

Figure 55. Influent and Effluent Dissolved Lead Concentration vs Influent Chloride Concentration

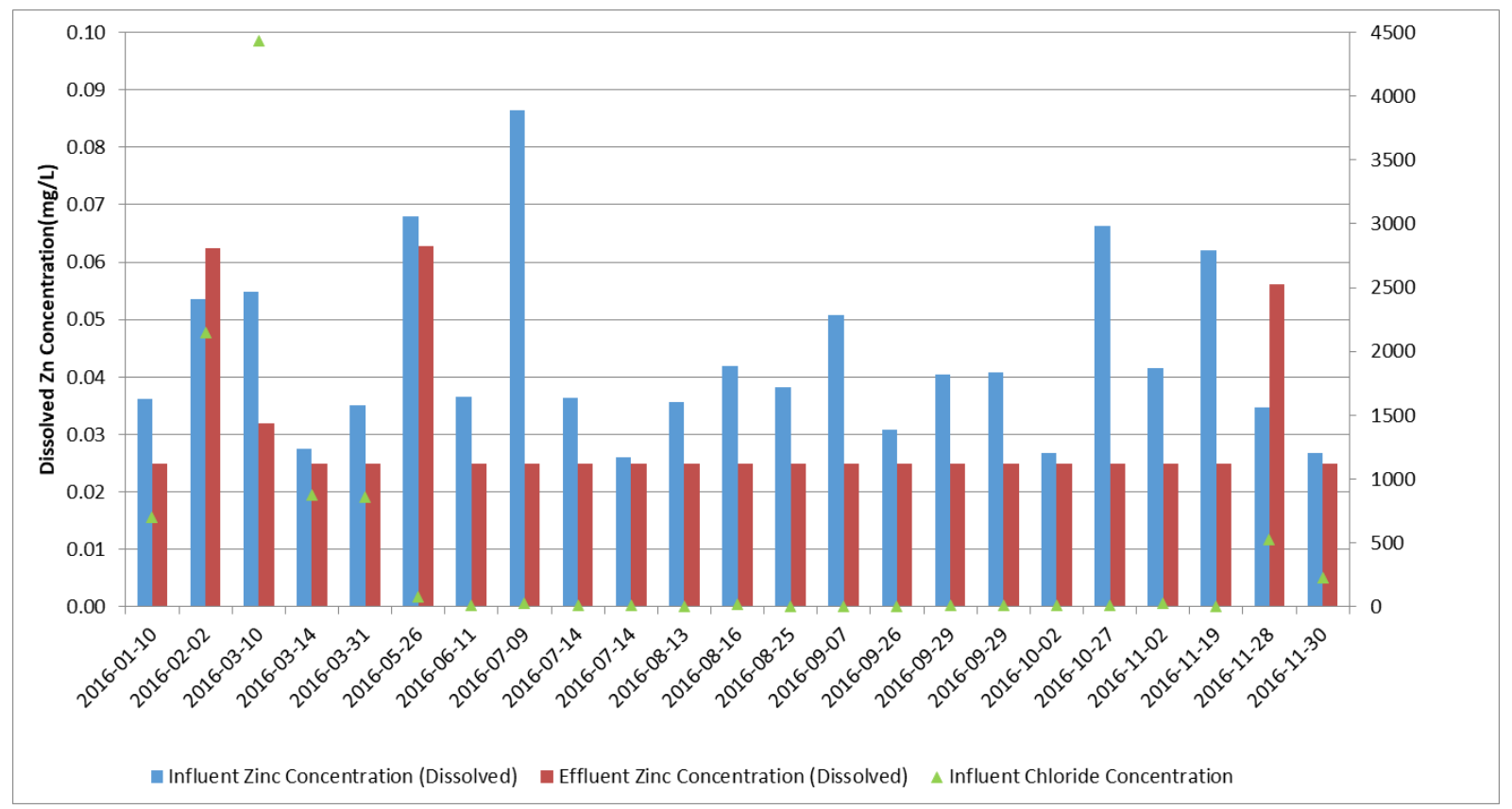

Figure 56. Influent and Effluent Dissolved Zinc Concentration vs Influent Chloride Concentration 
The metal shows different leaching patterns, but all leaching events for dissolved occurred between January to March and November, these leaching events all coincided with elevated chloride concentration. Chloride can affect the partition of metal concentration, increasing the concentration of the aqueous phase due to chloride complexation (Begeal 2008), and literatures have reported sodium ion in salt can displace weakly bonded metal ion thereby increasing the mobility of metal ions (Kakuturu and Clark 2015).

\section{Chloride Concentration Reduction}

The data shows that the soil cell is ineffective in reducing the salt concentration, this is occurred as expected. The persistence of salt in stormwater is a known issue as mentioned in Section 2.1.3, the search of literature did not return any examples where LID was able to significantly reduce the concentration of chloride.

The influent and effluent concentration pattern is shown in Figure 57.

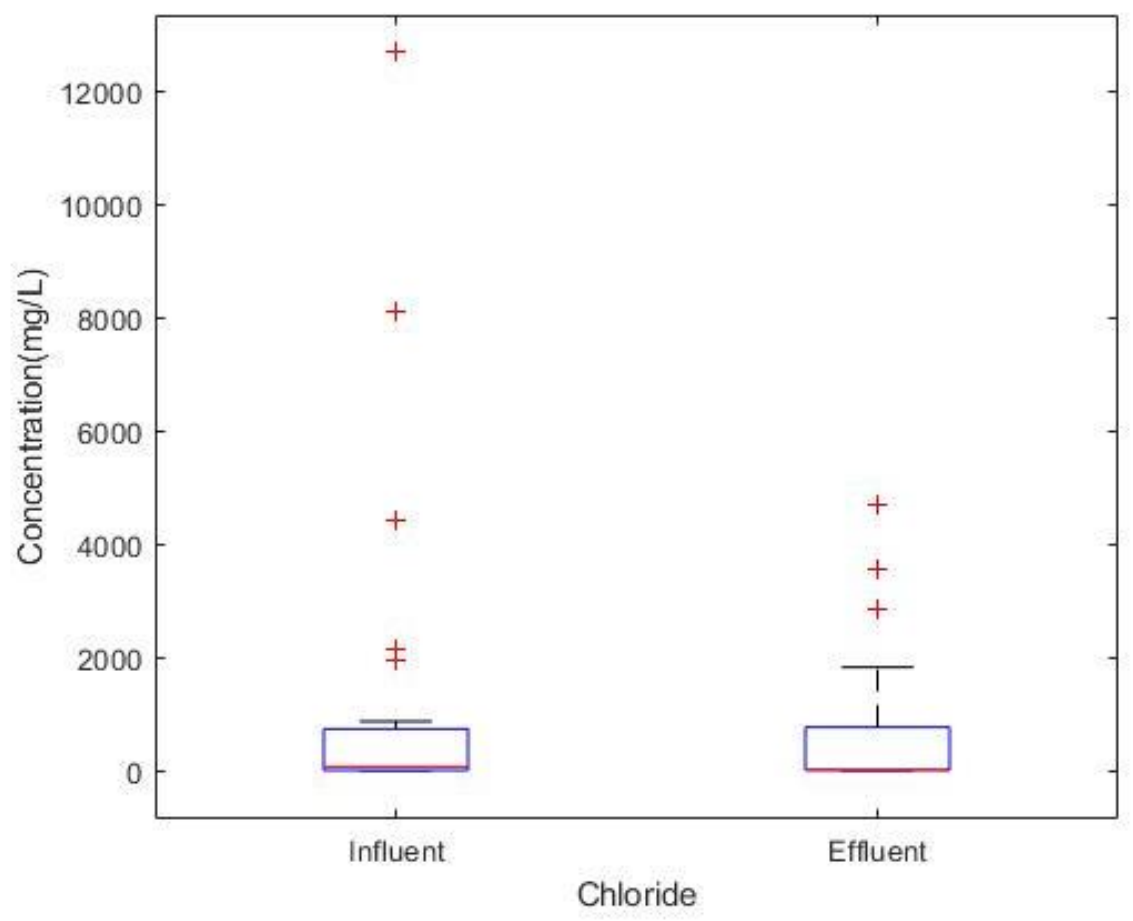

Figure 57. Chloride Concentration Comparison 
Pair wise comparison for matching samples is shown in Figure 58.

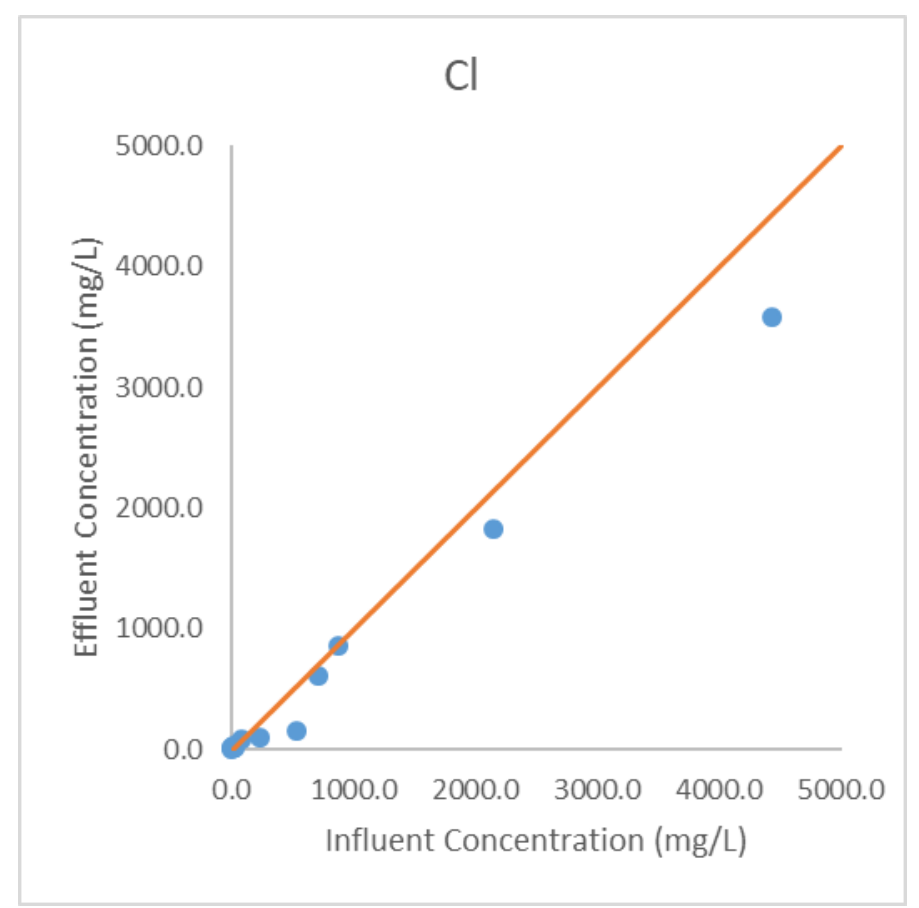

Figure 58. Pair Wise Comparison for Chloride

A strong correlation was observed between the inlet and outlet $\left(R^{2}=0.992, P=3.09 \mathrm{E}-21\right)$ with slope of 0.8159 . The effluent concentrations were reduced in a few events where influent concentration was high.

The temporal plot is shown in Figure 59. 


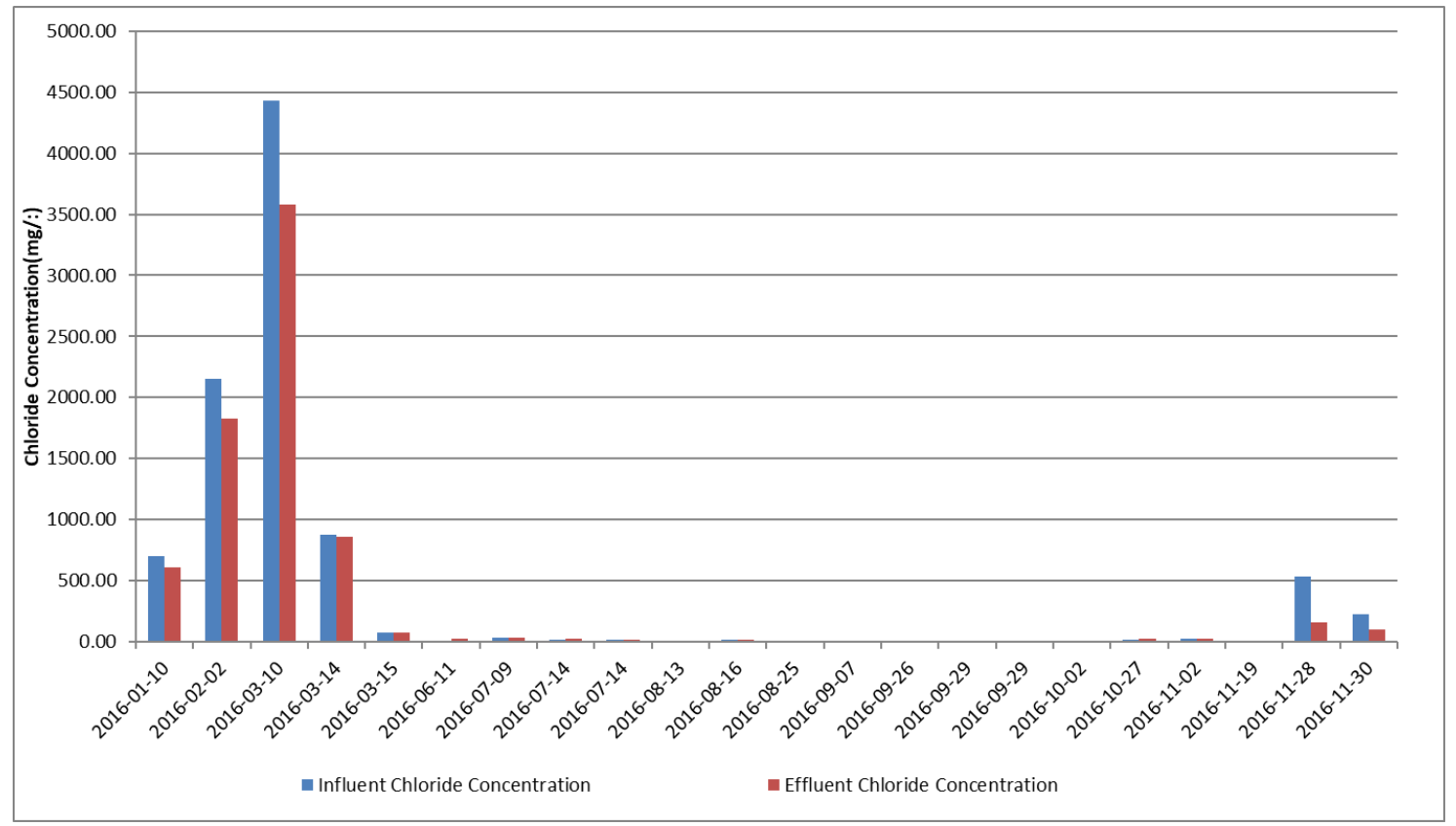

Figure 59. Temporal Distribution of Chloride Reduction and Influent Concentration

The temporal plot for summer months is shown in Figure 60 below:

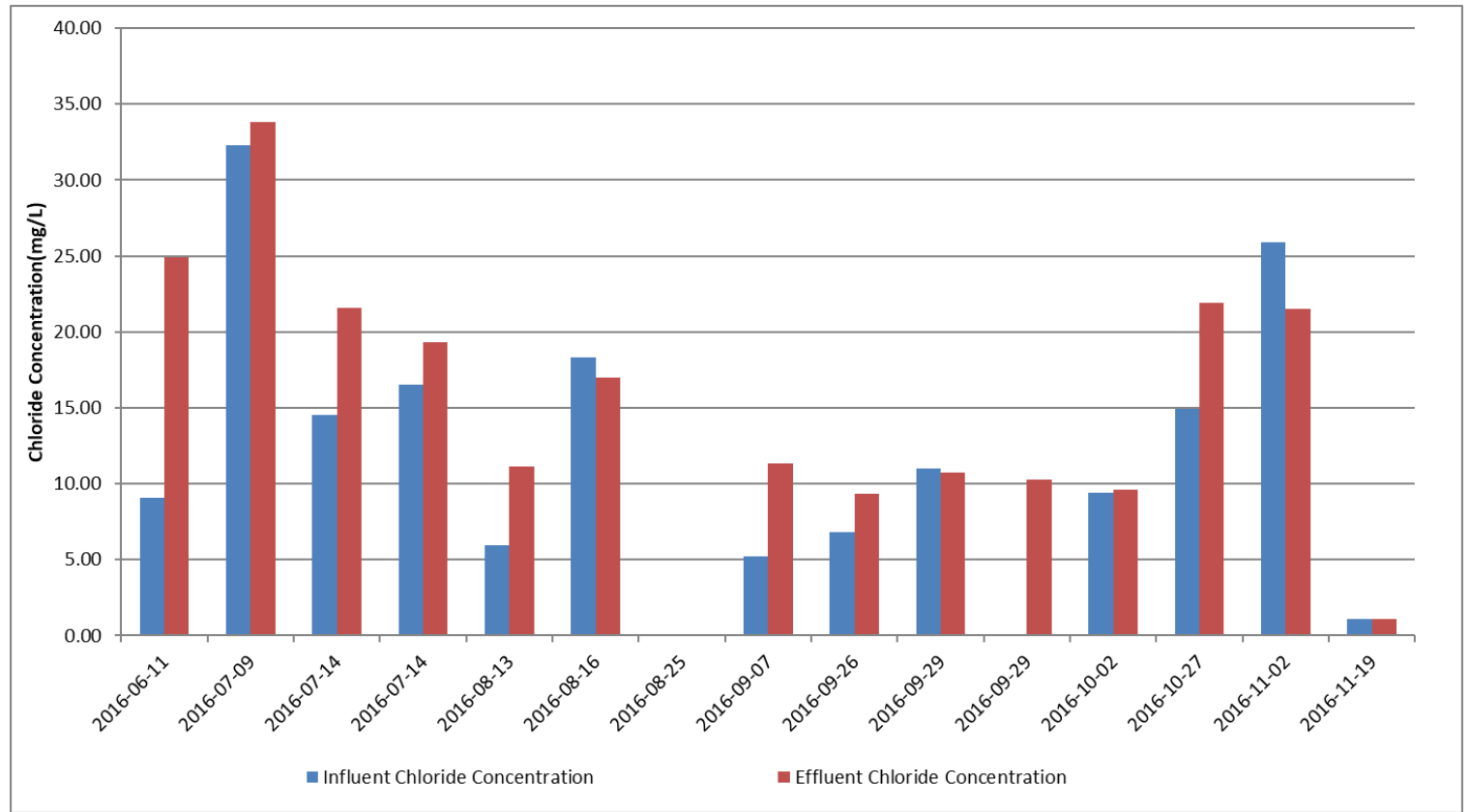

Figure 60. Temporal Distribution of Chloride Reduction and Influent Concentration During Summer 
Chloride concentration reductions were observed from November 11, 2016 to March 14, 2016, with reductions of $71 \%$ and $57 \%$ in the first two wash-off events, and $13 \%-19 \%$ in the late winter of early 2016. Concentrations increased by as much as $175 \%$ during the first rainfall event of summer and release of chloride was observed throughout summer and fall. This suggests the soil cell system can buffer the salt effluent concentration by absorbing chloride in winter and slowly releasing it during the summer. This is a corroborated phenomenon and was also observed in other study as well. (Denich et al. 2013).

\section{Biochemical Oxygen Demand Concentration Reduction}

The soil cell achieved a significant removal of $73 \%$ for BOD. Influent and effluent concentrations are provided in Figure 61 and are given a pair wise comparison in Figure 62.

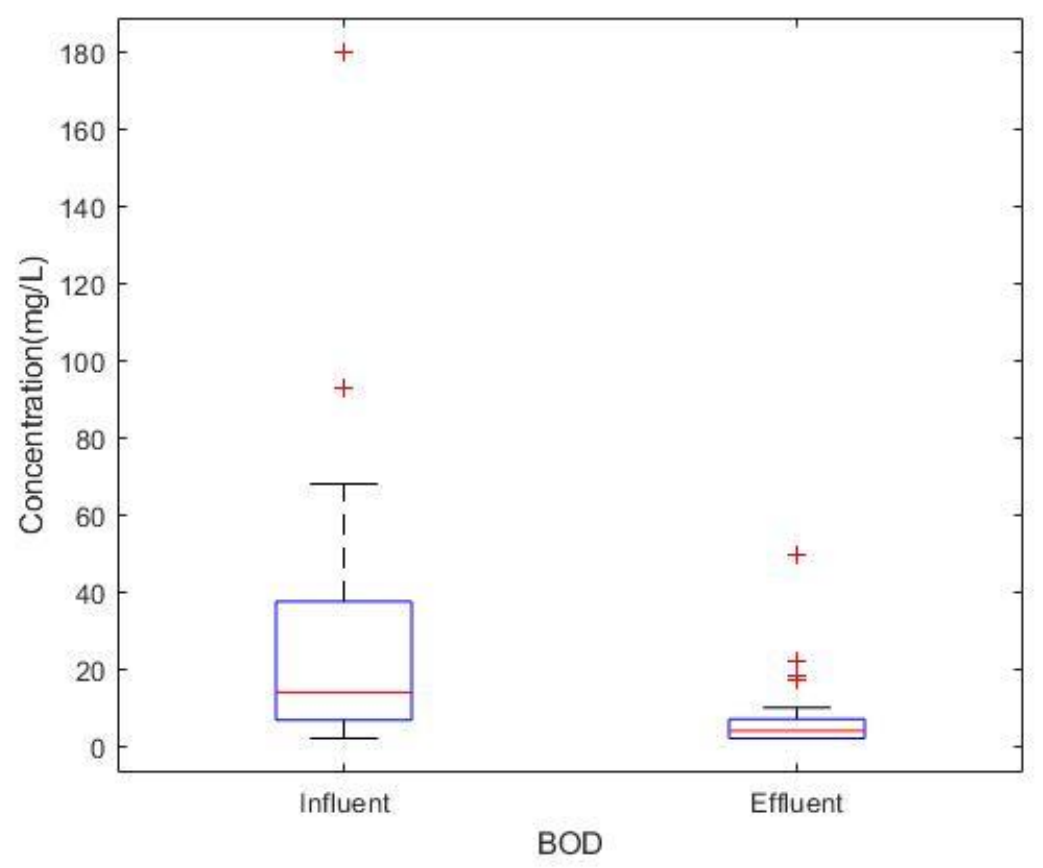

Figure 61. Biochemical Oxygen Demand Concentration Comparison 


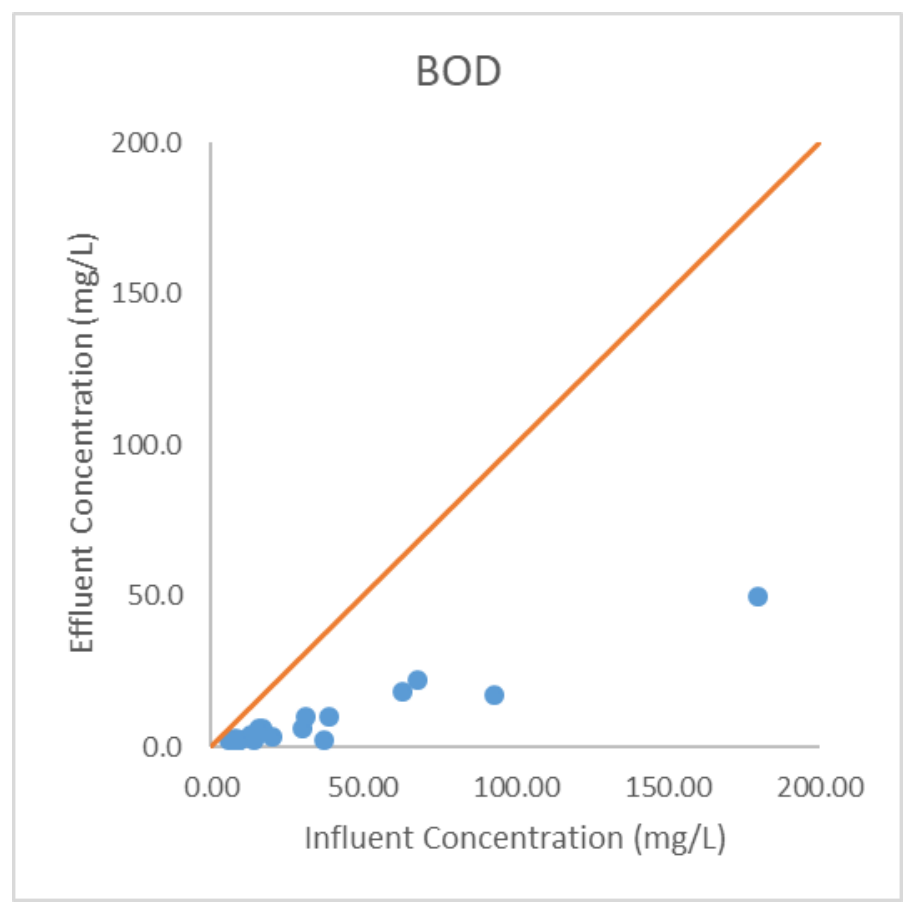

Figure 62. Pair Wise Comparison for BOD

The pair wise comparison exhibited a strong correlation between influent and effluent $\left(\mathrm{R}^{2}=\right.$ $0.9347, \mathrm{P}=3.76 \mathrm{E}-14)$ and the slope of the linear regression model $(0.2656)$ shows $26 \%$ of influent concentration remain in the effluent, which is consistent with $73 \%$ average removal efficiency for all events observed in 2016.

Temporal distribution of BOD removal efficiency is plotted in Figure 63. 


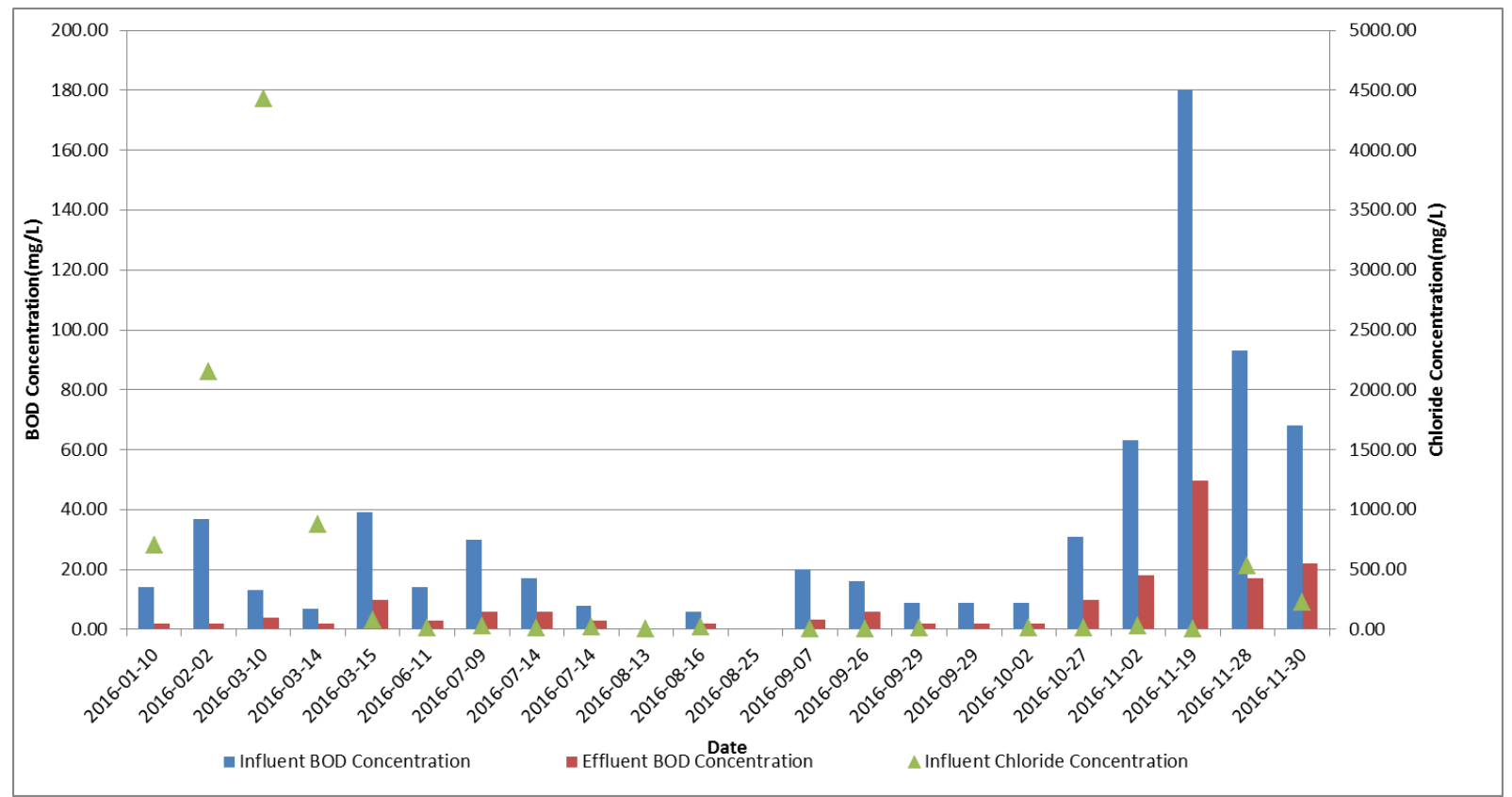

Figure 63. Temporal Distribution of BOD Concentration reduction

Elevated BOD loading of up to $300 \%$ was observed during the autumn. This is attributed to the leaf matters deposited by deciduous trees in the catchment area. The heavy traffic grinds leaves into fine particles as shown in Figure 64. 


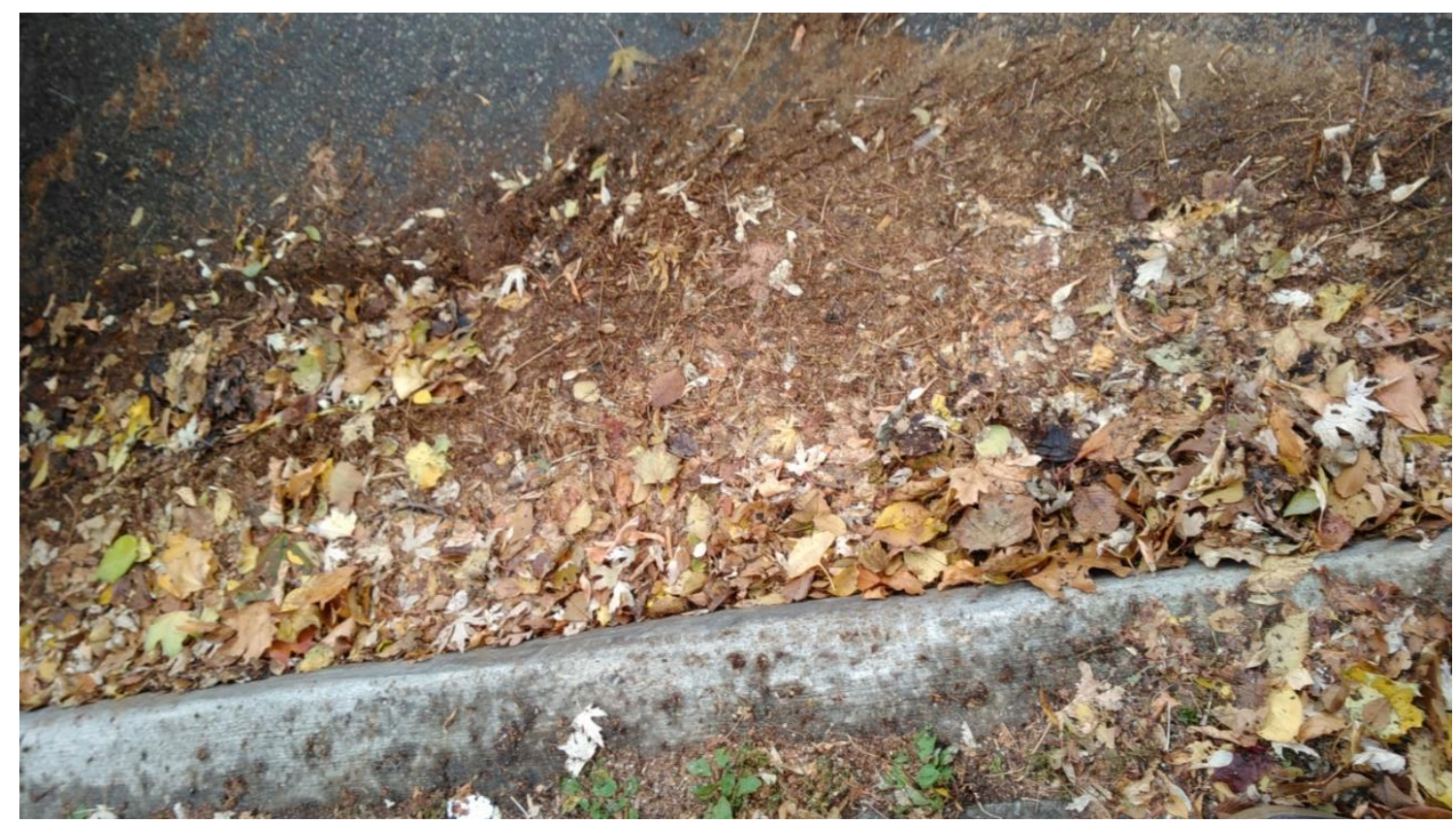

Figure 64. Leaves Matter on the Road in the Catchment Area

Over $60 \%$ of BOD were removed in all events but no clear seasonal patterns are observed for removal efficiency. Also note that the spike in chloride loading on November 28 and November 30 that caused metal and TSS leaching had no effect on BOD removal efficiency, it is possible that the average particle size for the increased BOD loading (i.e. crushed leaves) are larger than the pores in the soil medium, therefore easily filtered out.

\section{Phosphorus Removal}

The soil cell removed $74 \%$ of phosphorus and the inlet and outlet concentration is compared in Figure 65 and a pair wise comparison is provided in Figure 66. 


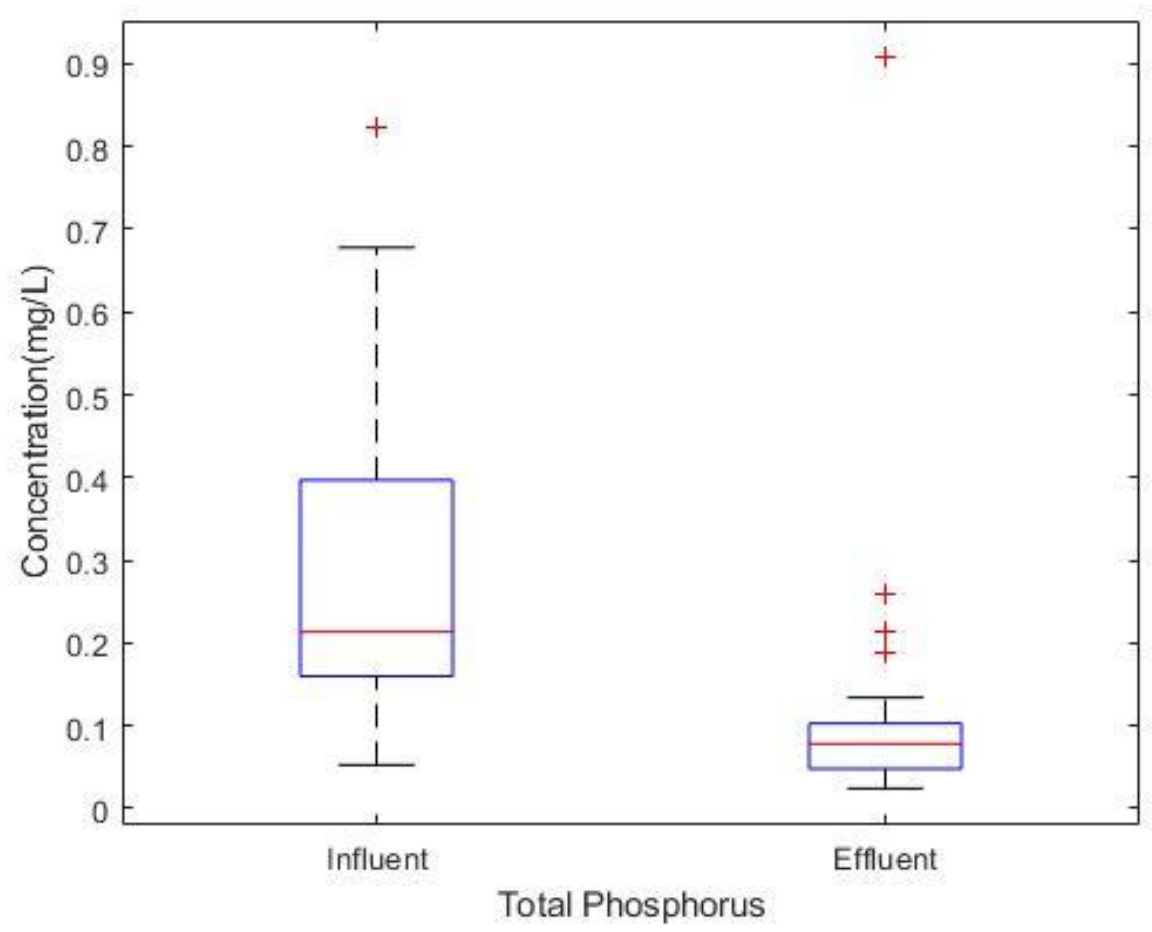

Figure 65. Phosphorus Concentration Comparison

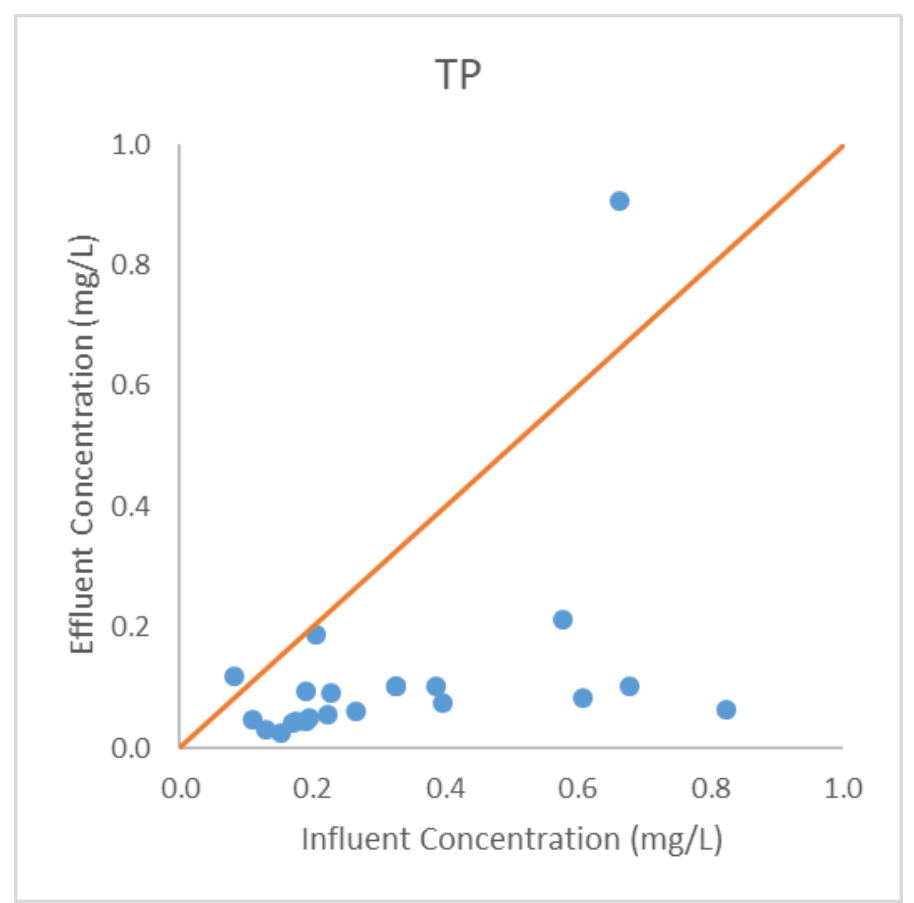

Figure 66. Phosphorus Concentration Comparison

Similar to TSS and metal there is no clear correlation $\left(\mathrm{R}^{2}=0.1742\right)$ between influent and effluent concentrations excluding the outlying events. 
Temporal distribution of concentration reduction is provided in Figure 67 below

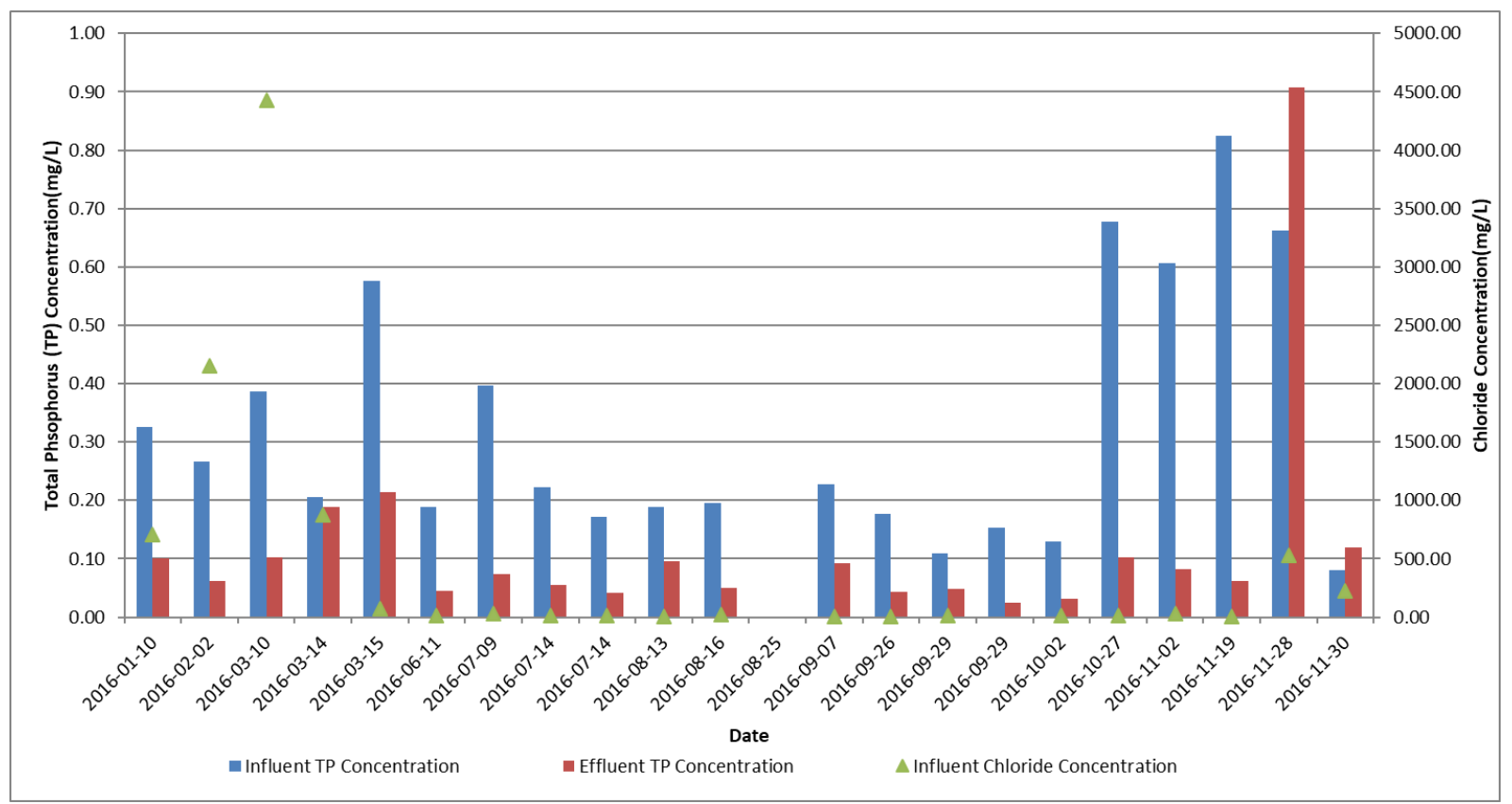

Figure 67. Temporal Distribution of Total Phosphorus Concentration Reduction

The two phosphorus leaching events also coincides with the first two salt wash-off events in late November, this suggests that the chloride can increase mobility of phosphorus. As previous studies have shown, phosphorus is not easily dissolved and remains in particulate form (Aryal et al 2010). The mechanism for TSS leaching and phosphorus could be the same.

Loading that increased significantly during late autumn can be attributed to the leaves as suggested by Yang and Toor (Yang and Toor 2017).

\section{Nitrate Concentration}

Nitrate was the only specie of nitrogen monitored during the operation, and it is the only pollutant that was observed to have a significant increase in concentration (65\% increase, though not statistically significant). The influent and effluent concentration distribution is provided in Figure 68 below: 


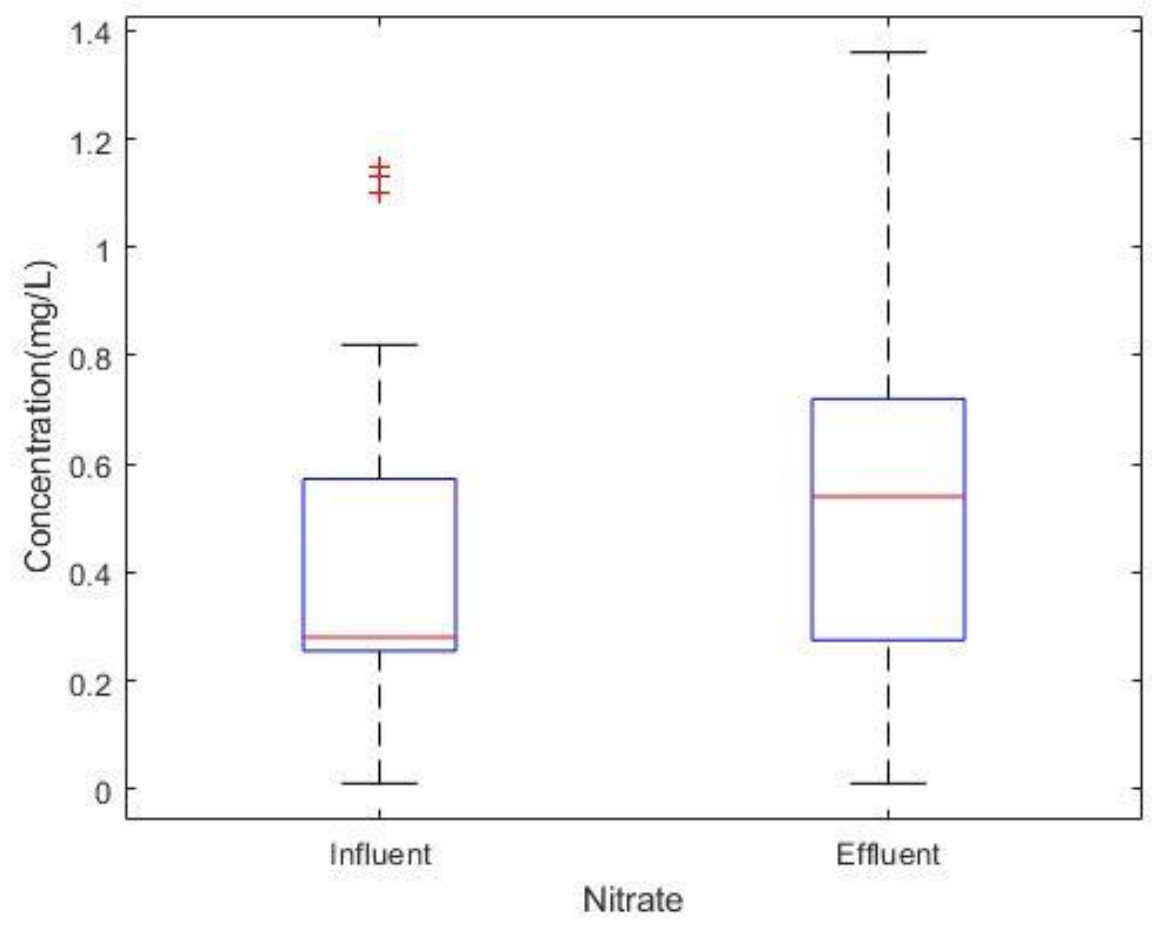

Figure 68. Nitrate Concentration Comparison

Pair wise comparison is provided in Figure 69 below:

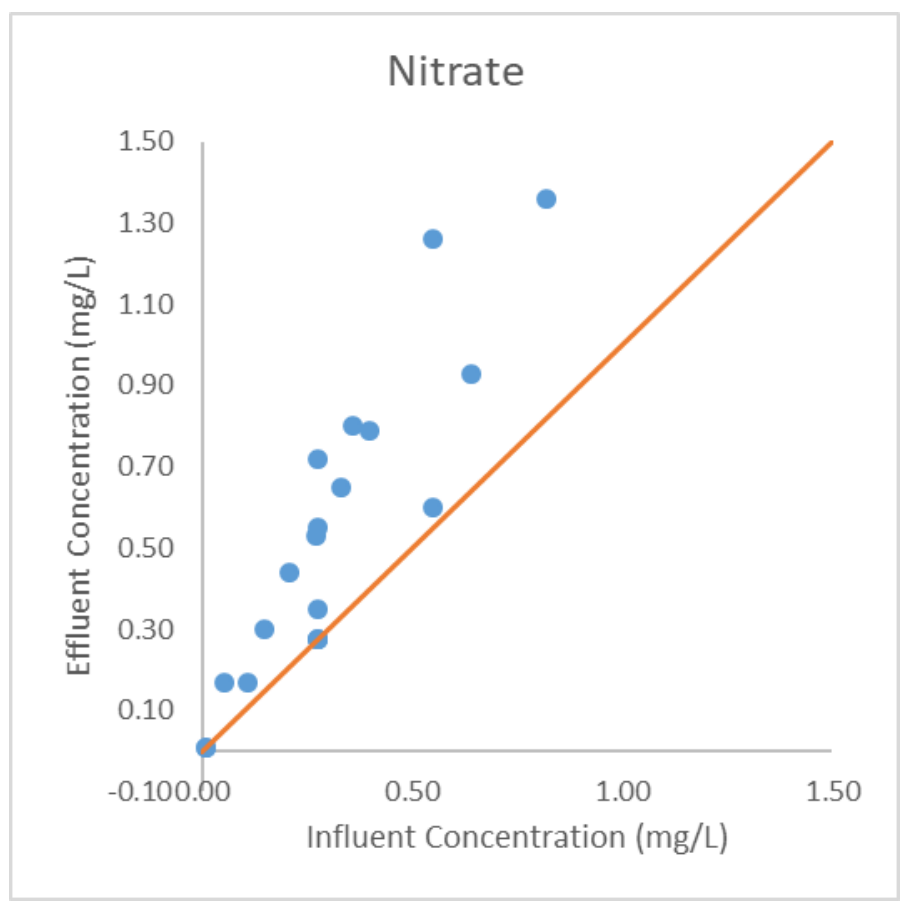

Figure 69. Nitrate Concentration Comparison 
Correlation was observed between influent and effluent $\left(\mathrm{R}^{2}=0.8071, \mathrm{P}=1.93 \mathrm{E}-12\right)$ with a regression slope of 1.6826, suggesting that the influent concentration has a causal relationship with effluent concentration.

The nitrate concentration was not observed to be reduced.

The temporal distribution is plotted in Figure 70.

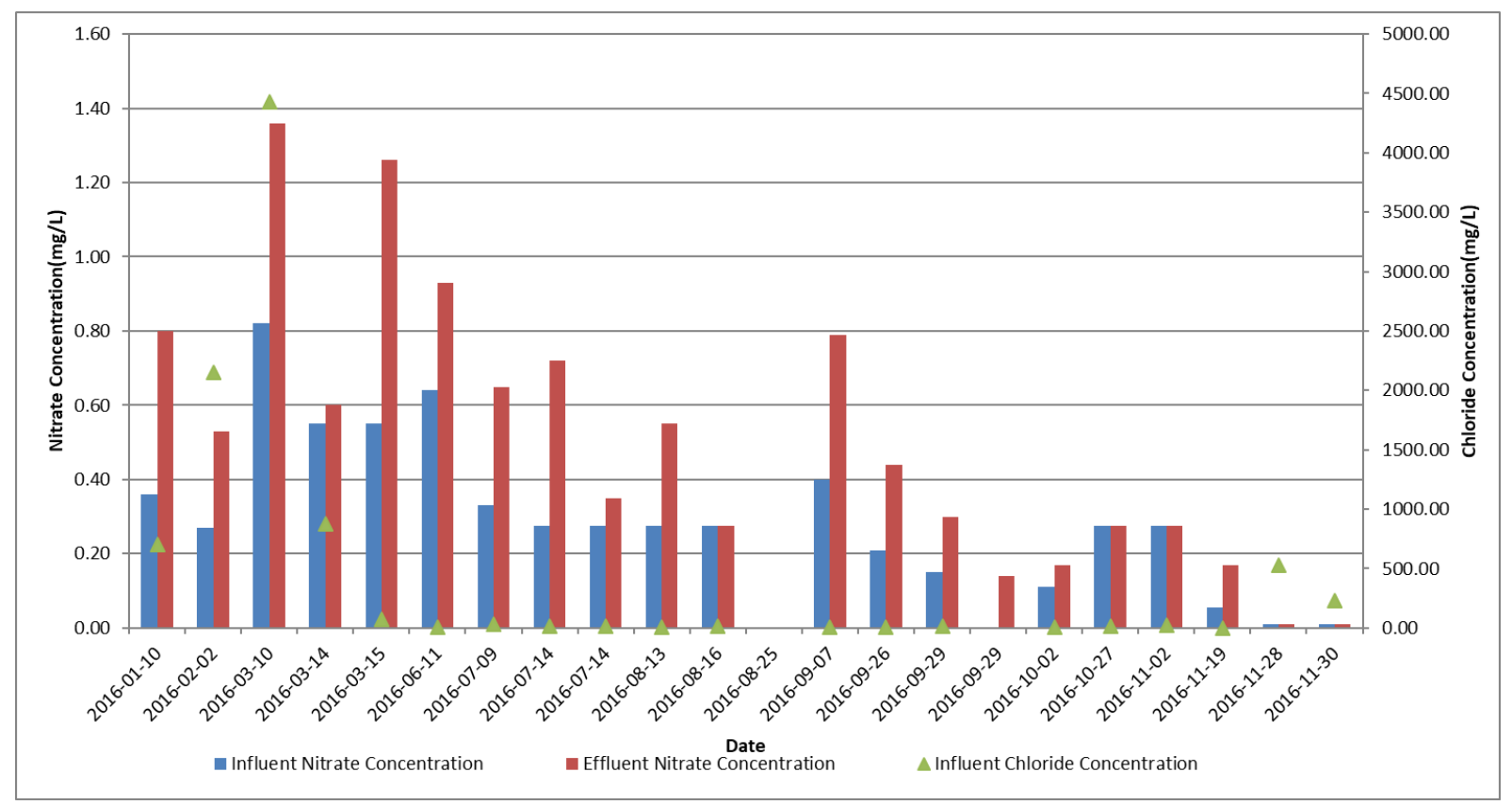

Figure 70. Temporal Distribution of Nitrate Concentration Reduction

The influent nitrate concentration during the two salt wash-off events were lowest of the year, however the concentration in the effluent did not change. It is known that nitrate is highly mobile and is not absorbed by soil particles (Lucas and Greenway 2011), therefore the transport mechanism for nitrate is not related to TSS.

The trend of increasing nitrate effluent concentration is a common problem observed in traditional bioretention cells by many researchers (Hatt et al. 2009; Davis et al. 2001). Furthermore, studies done by Green et al. have shown long term exposure to road runoff can disrupt the microbial life in soil causing increased nitrate leaching. (Green et al. 2008). 
Researchers have suggested that nitrate could be removed in traditional bioretention cell through a permanently saturated layer at the bottom of the bioretention cell facility in a manner similar to Infiltration / Filtration / Recharge facility discussed in 2.1.1. The saturated layer creates an anoxic condition in order to facilitate a denitrification process (Davis et al. 2001). The water level monitoring inside the cell has shown that no permanent ponding has occurred, despite a high flux of water into the soil cell on August 16th, as shown in Figure 71. 


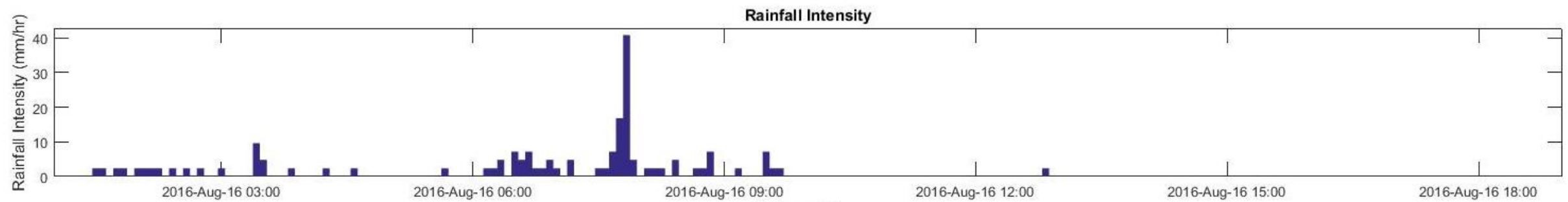

Date and Time

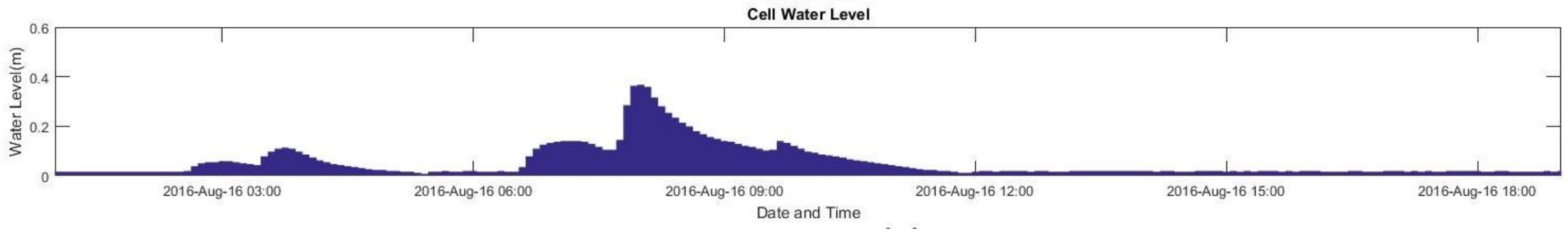

Figure 71. Water Level and Moisture Plot on August 16, 2016 


\section{$\underline{\text { Leaching Events }}$}

The two leaching events are examined in detail to ensure the samples were collected correctly, the event summary for November 28 and November 30 are shown in Figure 72 and Figure 73.

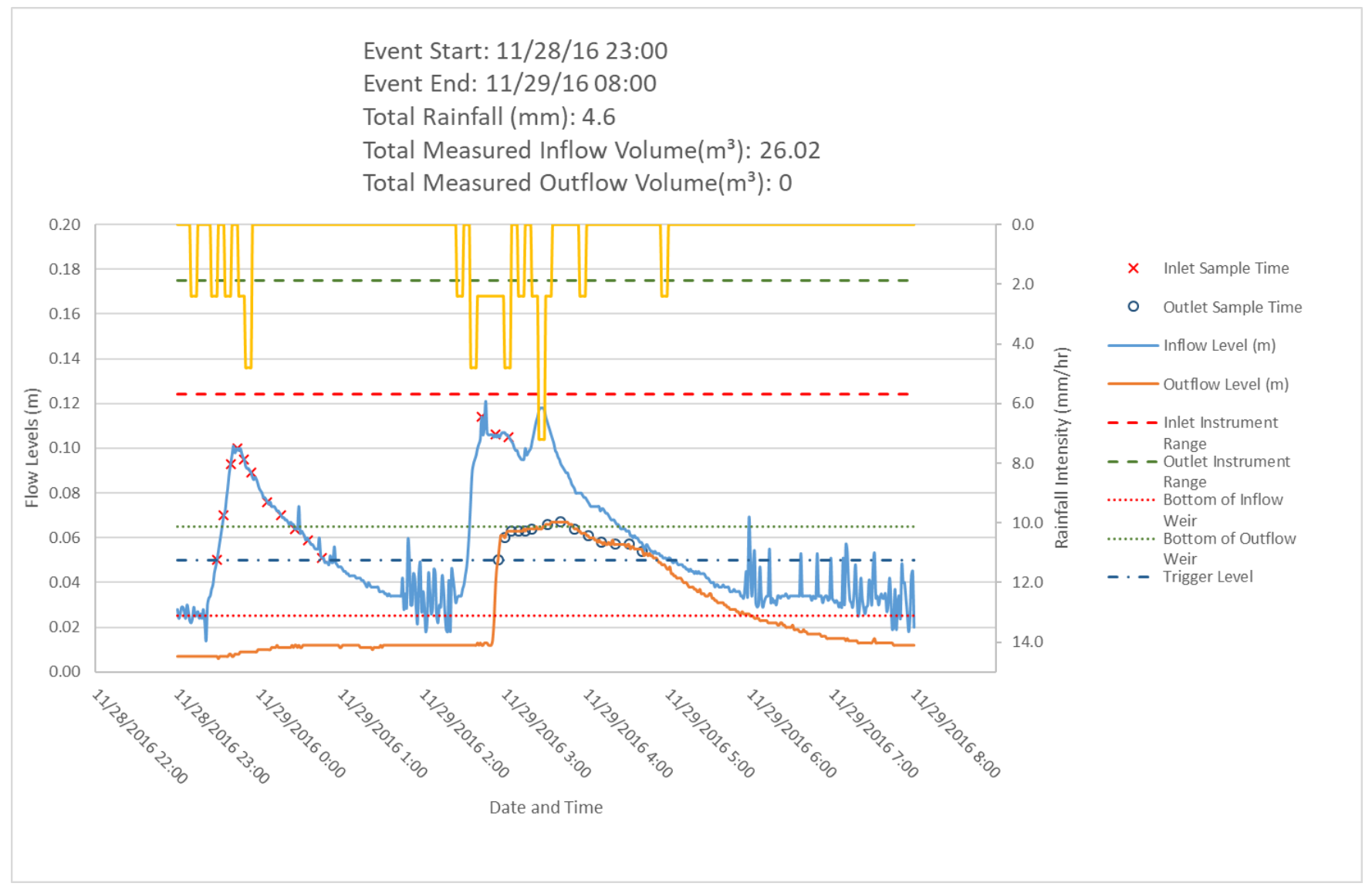

Figure 72. Summary Plot for November 28 Event

Two phases of the November 28 event were observed. The first phase occurred from November $28^{\text {th }}$ at $23: 10$ to $23: 50$, a total of $1.2 \mathrm{~mm}$ of rainfall was recorded. Inflow into the cell occurred as inlet elevation was observed to increase. Outlet level was observed $5 \mathrm{~m}$ from $0.07 \mathrm{~m}$ to $0.12 \mathrm{~m}$ and held stable, suggesting no outflow resulted from first phase of the event. Eleven influent samples were collected, no effluent samples were. 
The second phase of the event lasted from November $29^{\text {th }} 02: 25$ to 04:55 in the morning, a total of $3.4 \mathrm{~mm}$ of rainfall were recorded. Inflow and outflow both occurred as level at both locations increased three more influent samples and fourteen effluent samples were collected.

The influent samples corresponded to the first $3.0 \mathrm{~mm}$ of the storm, which should correspond the to first flush event. Effluent samples collection began at the first instance of outflow and lasted for approximately 50 minutes. Due to the faulty outlet weir, the volume is not known, but it did capture the elevated flow level which should represent peak outflow.

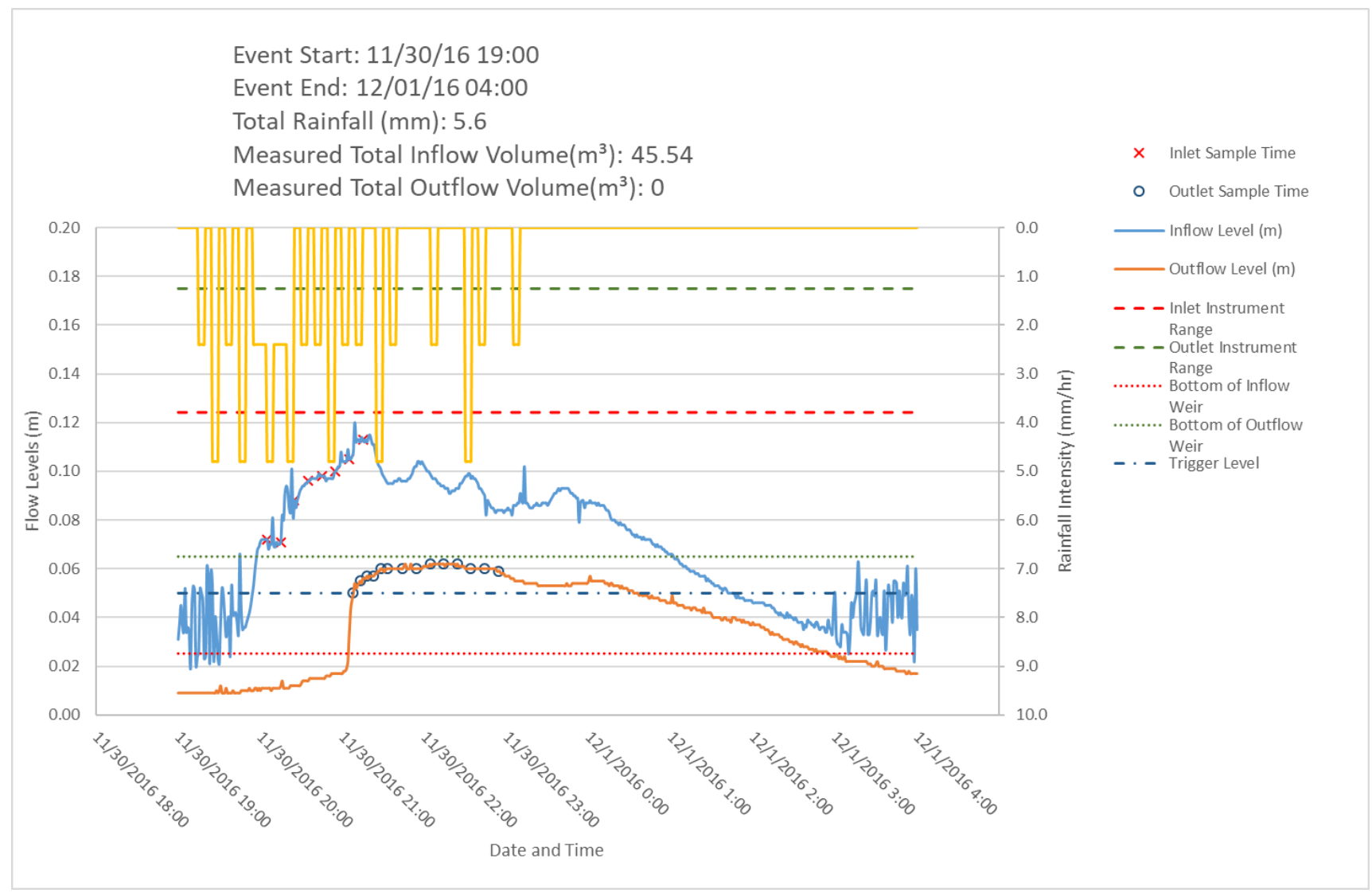

Figure 73. Summary Plot for November 30 Event 
The November $30^{\text {th }}$ event occurred in one phase, during which inlet samples were collected from 20:05 to 21:15. This corresponds to the first $4 \mathrm{~mm}$ of the rainfall event. Outlet samples were collected on November $30^{\text {th }}$ from 21:08 to $22: 54$ at the elevated outflow level.

Overall, influent samples should have captured the first flush while the effluent samples captured the first outflow. In both events samples are considered representative and collected correctly.

\section{Comparison with Bioretention}

The bioretention performance based on Table $\mathrm{x}$ and soil cell performance observed in 2016 as per Table $\mathrm{x}$ are compared in Table 11

Table 11. Pollutant Concentration Reduction Comparison between Soil Cell and Bioretention Cells

\begin{tabular}{|l|c|c|c|c|c|c|c|c|c|c|l|}
\cline { 2 - 11 } \multicolumn{1}{c|}{} & \multicolumn{10}{c|}{ Pollutant Concentration Reduction } \\
\hline LID Type & Al & BOD & Cl & Cu & Fe & Pb & Ni & NO $^{-}$ & TP & TSS & Zn \\
\hline Soil Cell & $82.0 \%$ & $73.0 \%$ & $-1.0 \%$ & $53.0 \%$ & $90.0 \%$ & $91.0 \%$ & $61.0 \%$ & $-65.0 \%$ & $74.0 \%$ & $92.0 \%$ & $71.0 \%$ \\
\hline $\begin{array}{l}\text { Bioretention } \\
\text { Cell }\end{array}$ & $60.3 \%$ & $23.3 \%$ & $-42.9 \%$ & $44.6 \%$ & $75.8 \%$ & $75.8 \%$ & $46.4 \%$ & $-50.0 \%$ & - & $73.0 \%$ & $76.3 \%$ \\
\hline
\end{tabular}

Traditional bioretention cells and soil cells have performed well in reducing concentration for TSS and metal, Iron leaching was observed in traditional bioretention cells while the soil cell could effectively treat it. However, leaching of iron may not be an inherited characteristic of bioretention cells, but rather a function of the backfill material native soil condition. Phosphorus treatment performance of the soil cell was significantly higher than bioretention cells; concentration reduction of total phosphorus of $74 \%$ were achieved by the cell while traditional bioretention cells were less effective. Literature has attributed leaching of phosphorus in bioretention cells to high organic content in the backfill media and suggested leaching can occur in the early stage of its operation(Hsieh and Davis 2005). It should be noted the soil cell has been in operation for many years prior to the monitoring operation. 
The soil cell also suffers from the same drawback as traditional bioretention cells, namely its inability to treat chloride and the increase in leaching of nitrate. Chloride remains an industrywide challenge with no currently available solution for an effective treatment; hence the results were expected. The anoxic condition required for nitrate reduction did not occur in the soil cell despite being underground and enclosed in a non-permeable layer.

\subsubsection{Water Quantity}

The measured influent volume for this monitoring operation was highly questionable as it varied greatly with the expected runoff volume estimated by established methods.

The expected runoff quantity can be expressed using the SCS Curve Number method expressed in Equation 7

Where:

$$
Q_{d}=\frac{\left(P-I_{a}\right)^{2}}{\left(P-I_{a}\right)+S}
$$

$Q_{d}$ is the runoff depth in millimetre

$P$ is the rainfall depth in millimetre

$S$ is the maximum retention, it is a function of land use expressed using $S=\frac{1000}{C N}-10$

Equation 8Equation 8 below:

$$
S=\frac{1000}{C N}-10
$$

Equation 8

$C N$ for a drainage basin consisting of an urban road is typically taken as 98

$I_{a}$ is the initial abstraction, recent literature suggests this value should be taken as 0.05S (Lim, 
Engel, Muthurishan, \& Harbor, 2006)

Substituting Equation 8 and $\mathrm{CN}$ into Equation 7 to obtain Equation 9.

$$
Q_{\text {Runoff }}=\frac{(P-0.05 \times 0.204)^{2}}{(P+0.95 \times 0.204)}
$$

Equation 9

It is possible that the catchment basin grate could be the limiting factor restricting the inflow. According to a hydrologic modelling guideline published by city of Toronto, the type of grate used at the site is capable of accommodate a maximum flow rate of 51L/s (assuming curb height of $110 \mathrm{~mm}$ and a slope of less than $0.5 \%$, similar to conditions previously measured) (City of Toronto 2014). This is equivalent to the peak runoff resulting from a rainfall with intensity of $180 \mathrm{~mm} / \mathrm{hr}$, which was never exceeded in 2016.Therefore the catchment grate was not a limiting factor.

The estimated runoff using Equation 8 is plotted against the measured runoff in Figure 74. The majority of the measured runoff volume exceeded the estimate and a poor correlation between the two was observed. 


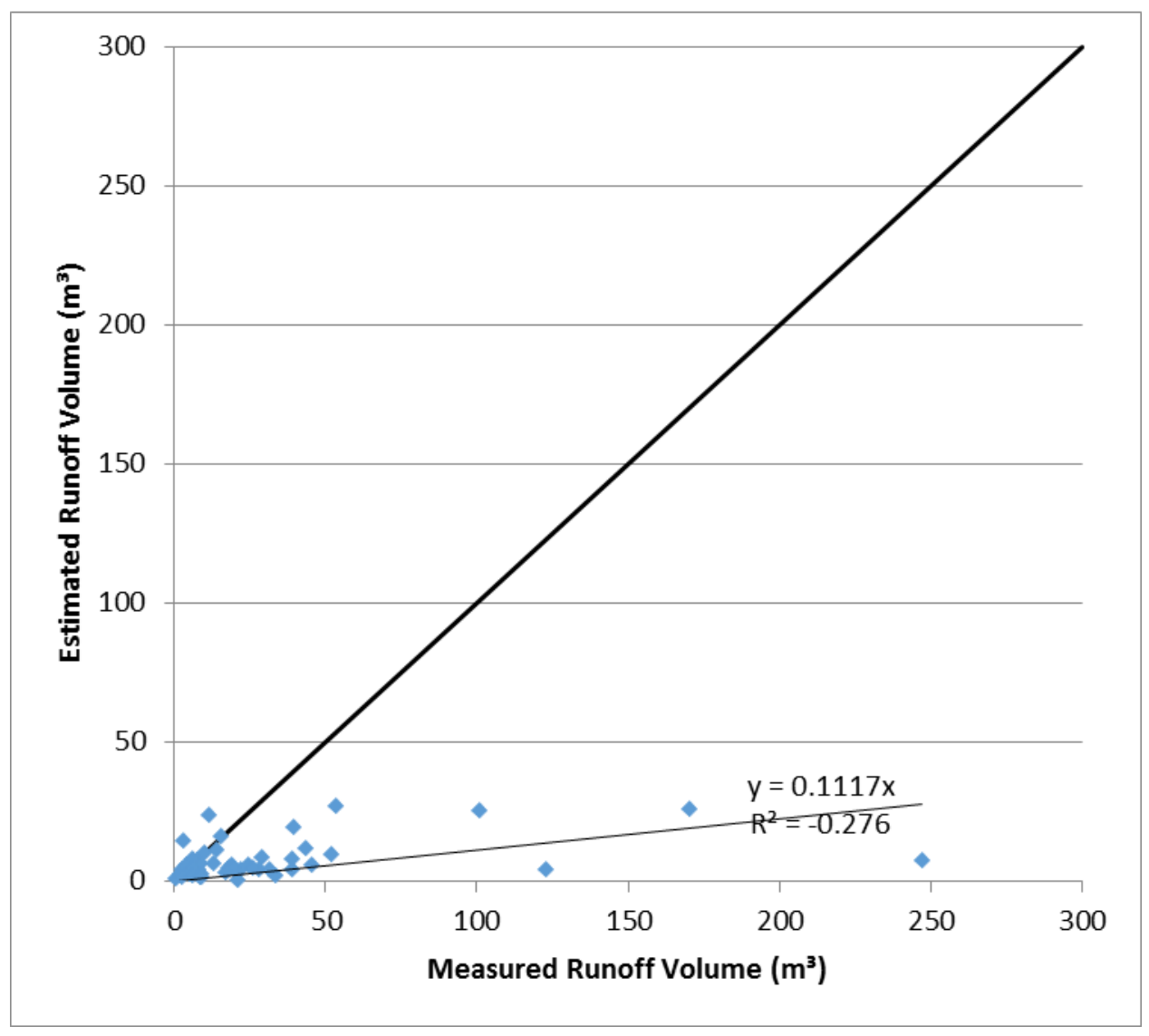

Figure 74. Estimated Runoff vs Measured Runoff

The difference between measured and estimated often varies by factor of 10 .

The cause of the error was attributed to the improper measurement technique, i.e. the use of a weir. One simulated rainfall test was conducted on June 6, 2016 by directing the flow from a nearby hydrant into the catchment area. Water in the catchment basin was found to be stagnant and quickly accumulated over the weir after the flow began. This suggests the water in the downstream could not flow freely due to clogging or an insufficient rate of exfiltration. In cases where the weir is submerged, weirs will overestimate the flow rate. The possibility of an overestimate due to the weir cannot be excluded during rainfall events, therefore the inflow measurement taken during the operation cannot be relied upon. 
The effluent quantity measurement during this operation was problematic as well. The measured water level in the downstream pipe was observed to fluctuate; however, the outflow level rarely registered above the notch of the bottom weir, thus outflow volume was registered as such for most cases. During the same June 26 test, outflow was observed to be active while the water level reading was below the notch of the weir. This suggests the flow is able to bypass the weir, significantly underestimating the outflow volume, therefore the outflow measurement result also cannot be relied upon.

An example of the backup at inlet and leak at outlet is shown in Figure 75. 


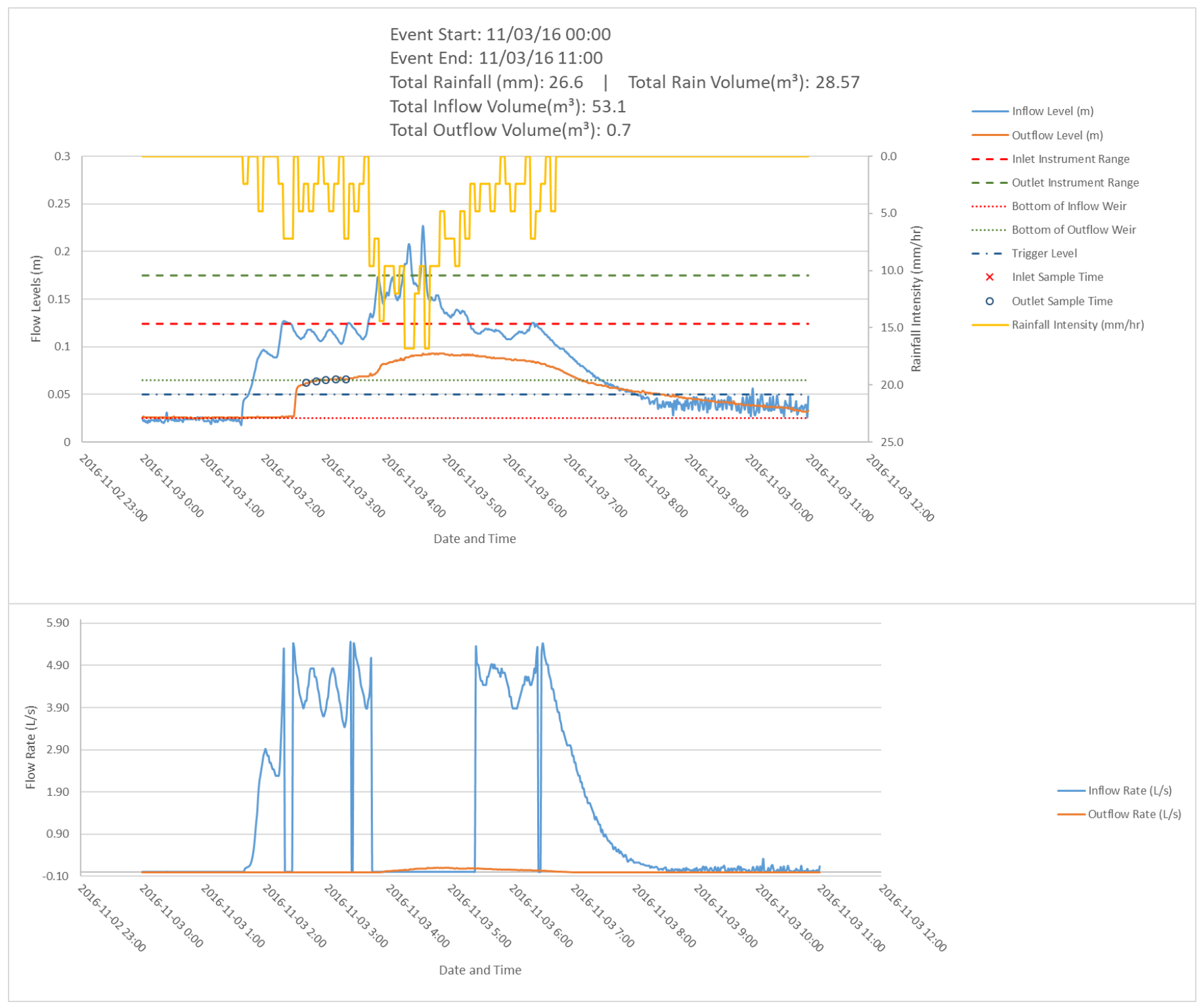

Figure 75. Example of Inlet Backup and Outlet Leak.

Inlet surged beyond the instruments range from between approximately 3:50AM to 5:20AM.

The flow rate for this time range cannot be obtained therefore it had to be dropped.

Despite the heavy inflow, the outflow barely registered above the bottom of the outlet weir and continued to fall after approximately 7:20AM where the outlet level fell below the bottom of the weir. 


\section{Water Balance}

As the direct measurement of influent and effluent is unavailable due to an equipment failure, alternative surrogates must be considered.

Soil moisture data and water level data in the cell was available and considered as a surrogate for the water volume retained in the soil cell. However, the growth of the tree roots and accumulated pollutants over the years may have reduced the soil void volume to such a degree that a reliable estimation of retained water in the soil cell can not be established through a surrogate.

Due to the unavailable water quantity measurement flow volume reduction, peak reduction and peak delay could not be established.

\subsubsection{Tree Health}

Aerial photos of the sites are available on City of Toronto's GIS website, the photos taken in late spring of 2012 and 2016, was used to measure the spread of the crown. Photos from the years 2011 and 2015 did not show the crown clearly therefore were not used.

Crown diameters of each of the trees was measured parallel to The Queensway (E-W) and then perpendicularly to The Queensway $(\mathrm{N}-\mathrm{S})$. The two measurements are used to calculate the average spread. The results of the measurement and volume is tabulated in Table 12, and tree crown growth is shown in Figure 76. 
Table 12. Tree Crown Spread Measurements

\begin{tabular}{|c|c|c|c|c|c|c|c|c|c|}
\hline \multirow{3}{*}{ Cells } & \multirow{3}{*}{ Trees } & \multicolumn{8}{|c|}{ Year } \\
\hline & & 2011 & \multicolumn{3}{|c|}{2012} & 2015 & \multicolumn{3}{|c|}{2016} \\
\hline & & & E-W ø & N-S ø & $\begin{array}{c}\text { Average } \\
\text { spread }\end{array}$ & & E-W ø & N-S ø & $\begin{array}{c}\text { Average } \\
\text { Span }\end{array}$ \\
\hline \multirow{2}{*}{ Wet } & East Tree & \multirow{4}{*}{$\begin{array}{l}\text { Unable } \\
\text { to } \\
\text { measure }\end{array}$} & $2.99 \mathrm{~m}$ & $3.23 \mathrm{~m}$ & $3.11 \mathrm{~m}$ & \multirow{4}{*}{$\begin{array}{l}\text { Unable } \\
\text { to } \\
\text { measure }\end{array}$} & $8.49 \mathrm{~m}$ & $6.38 \mathrm{~m}$ & $7.44 \mathrm{~m}$ \\
\hline & West Tree & & $2.91 \mathrm{~m}$ & $2.16 \mathrm{~m}$ & $2.54 \mathrm{~m}$ & & $6.02 \mathrm{~m}$ & $4.94 \mathrm{~m}$ & $5.48 \mathrm{~m}$ \\
\hline \multirow{2}{*}{ Dry } & East Tree & & $3.03 \mathrm{~m}$ & $3 \mathrm{~m}$ & $3.02 \mathrm{~m}$ & & $6.07 \mathrm{~m}$ & $5.63 \mathrm{~m}$ & $5.85 \mathrm{~m}$ \\
\hline & West Tree & & $2.43 \mathrm{~m}$ & $2.19 \mathrm{~m}$ & $2.31 \mathrm{~m}$ & & $5.28 \mathrm{~m}$ & $5.27 \mathrm{~m}$ & $5.28 \mathrm{~m}$ \\
\hline
\end{tabular}

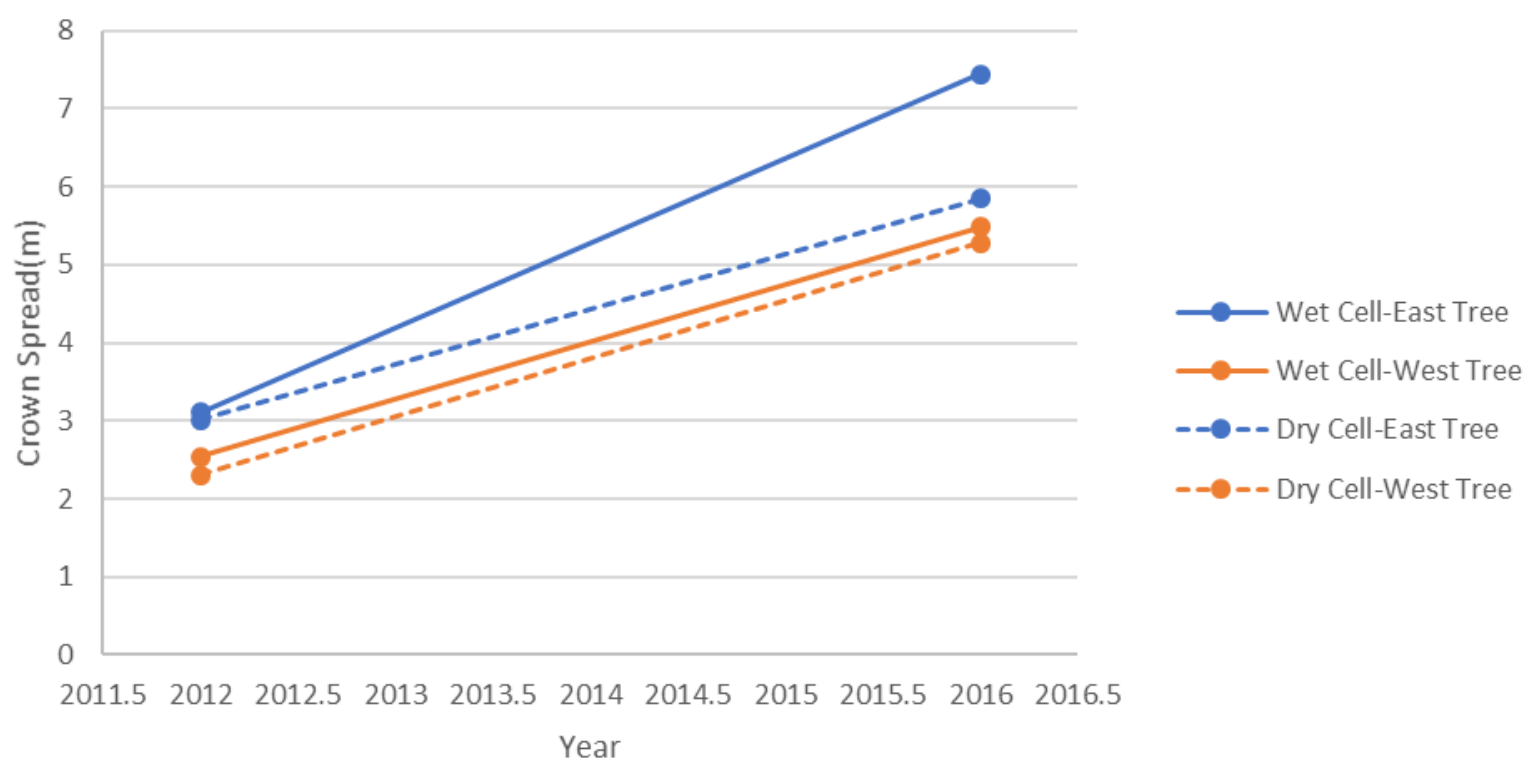

Figure 76. Growth of Tree Crown

The average crown spread of the two trees in the wet cell grew at a rate of $0.91 \mathrm{~m}$ per year, while the two trees in the dry cell grew at $0.73 \mathrm{~m}$ per year. This result is contrary to observation made by Ordóñez-Barona et al(Ordóñez-Barona et al. 2018) where they observed high tree mortality rate, however it was not clear whether or not the soil cell in their study was flushed in the summer by rainfall. 
Insufficient past observational data prevents a more detailed analysis of the trees' health. Nevertheless, the current data does not suggest that irrigating trees with road runoff in soil cell will negatively impact the trees' health.

\subsubsection{Limitations}

The results reported in this section should not be taken without a few caveats with regards to potential sources of error.

The water quantity monitoring operation was unsuccessful, as too many uncertainties with regards to the current state of the soil in the cell prevents further analysis.

The unsuccessful flow rate monitoring prevents the adoption of a flow portioned sampling strategy and a time-portioned monitoring had to be used. As previously discussed, a time portioned strategy is the less accurate of the two strategies and research published by Khan et al. have suggests samples captured during the early periods of the event tends to overestimate pollutant concentration while samples in the late stage underestimate the concentration of pollutants (Khan et al. 2006). As the sampling interval in this operation remains the same for all events, it is unlikely the correct time-portioning is achieved in events of different durations. Events with low intensity in the beginning may not trigger sampling, however the later portions will be sampled, and in these cases the concentration will be underestimated. Events of long durations exceeding sampling capacity will not produce samples in later period, and in these cases the concentration will be overestimated. 


\subsection{Hydraulic Performance of Perforate Pipes}

The minimum flow rate provided by the pump was 10 Gallons per Minute (GPM) and the maximum capacity of the pump provided $163 \mathrm{GPM}$, as measured at the paddle wheel flow meter. The perforated pipe was tested at various flow rates between the maximum and minimum.

The flow and upstream water level in the upper tank fluctuated heavily when rates were increased. Accordingly, an adjustment period was given to allow the system to reach a state of equilibrium before measurements were taken. Measurements were taken five minutes apart for a period of 20 minutes.

The measured upstream water level and measured pressure are plotted in Figure 77 to Figure 82.

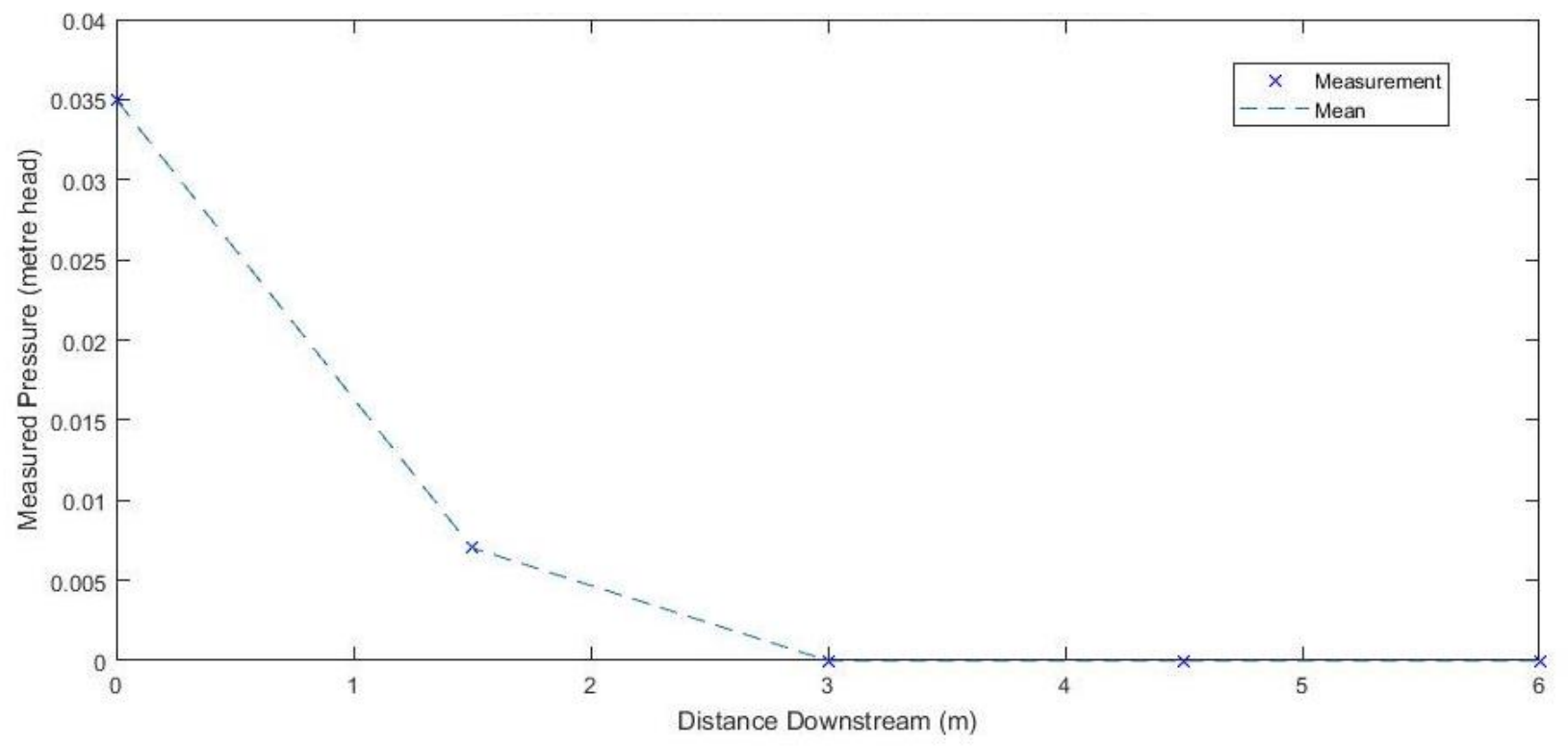

Figure 77. Hydraulic Gradient for Flow Rate of $0.63 \mathrm{~L} / \mathrm{s}$ 


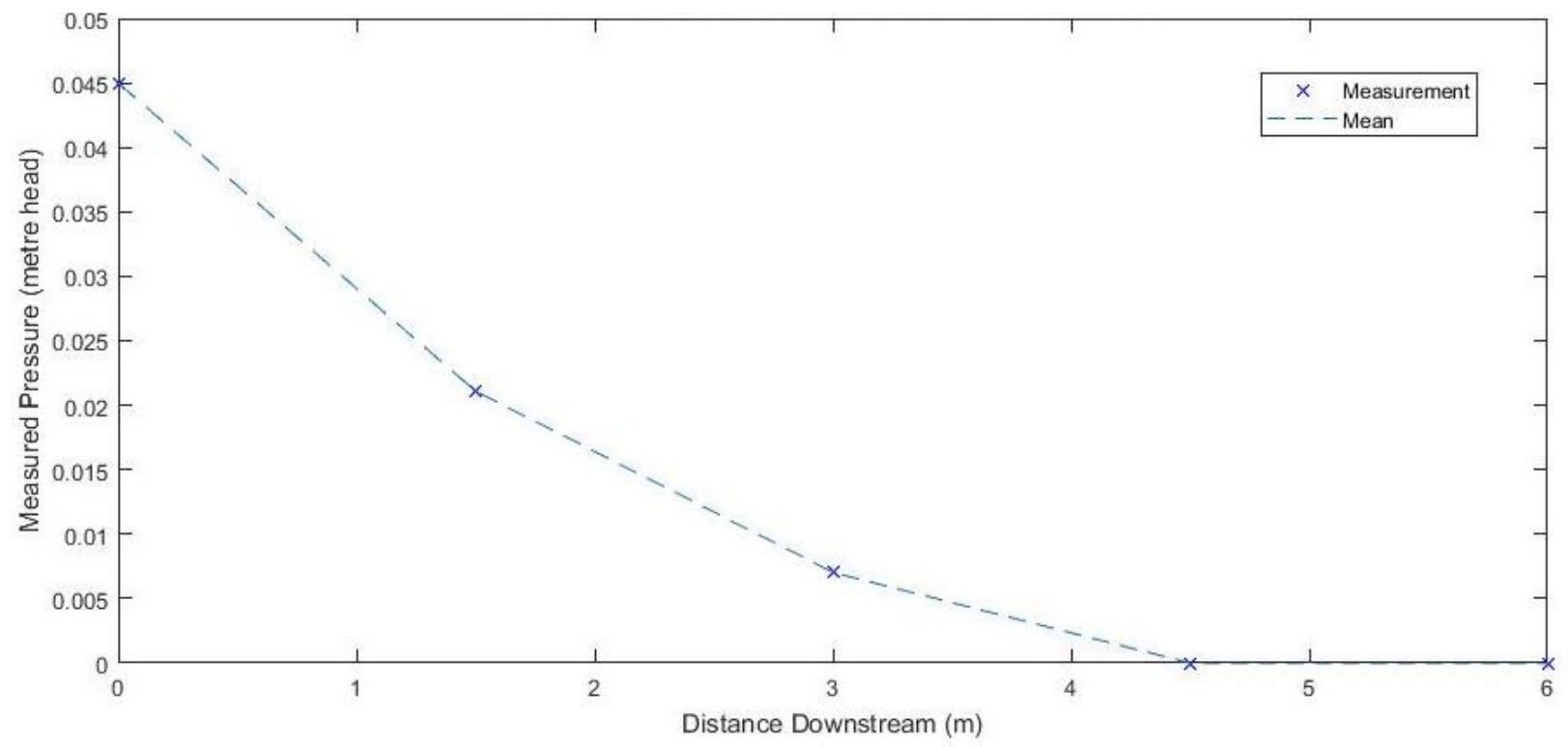

Figure 78. Hydraulic Gradient for Flow Rate of 1.01L/s

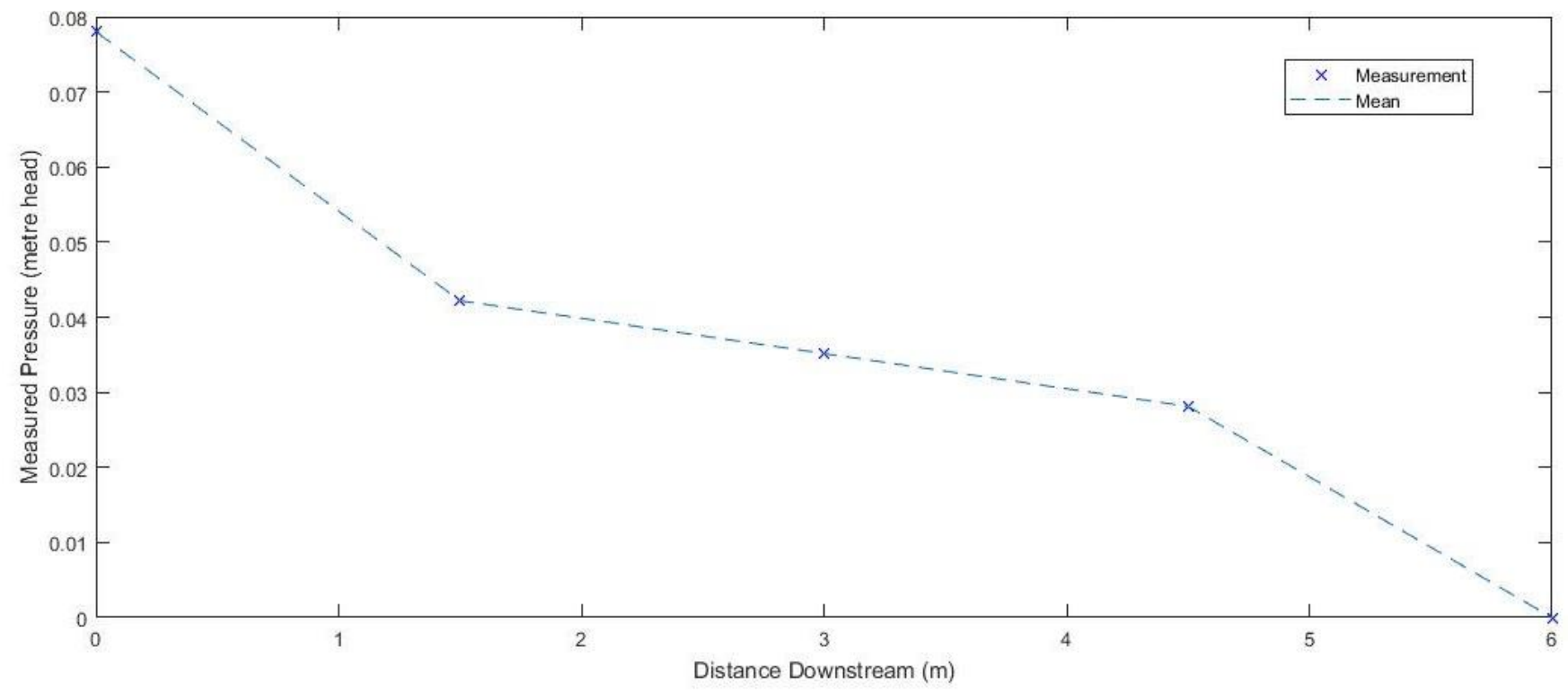

Figure 79. Hydraulic Gradient for Flow Rate of $2.02 \mathrm{~L} / \mathrm{s}$ 


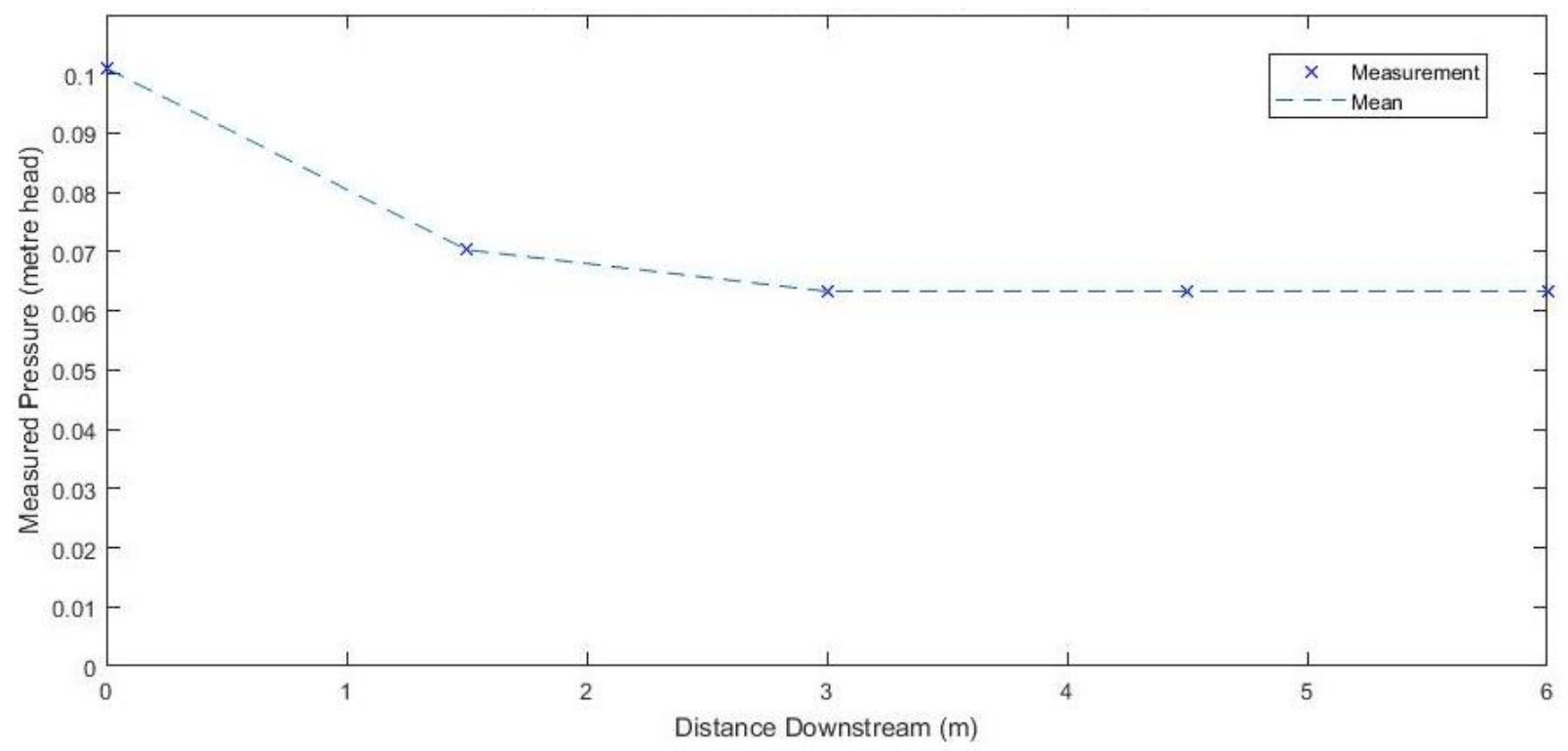

Figure 80. Hydraulic Gradient for Flow Rate of 4.04L/s

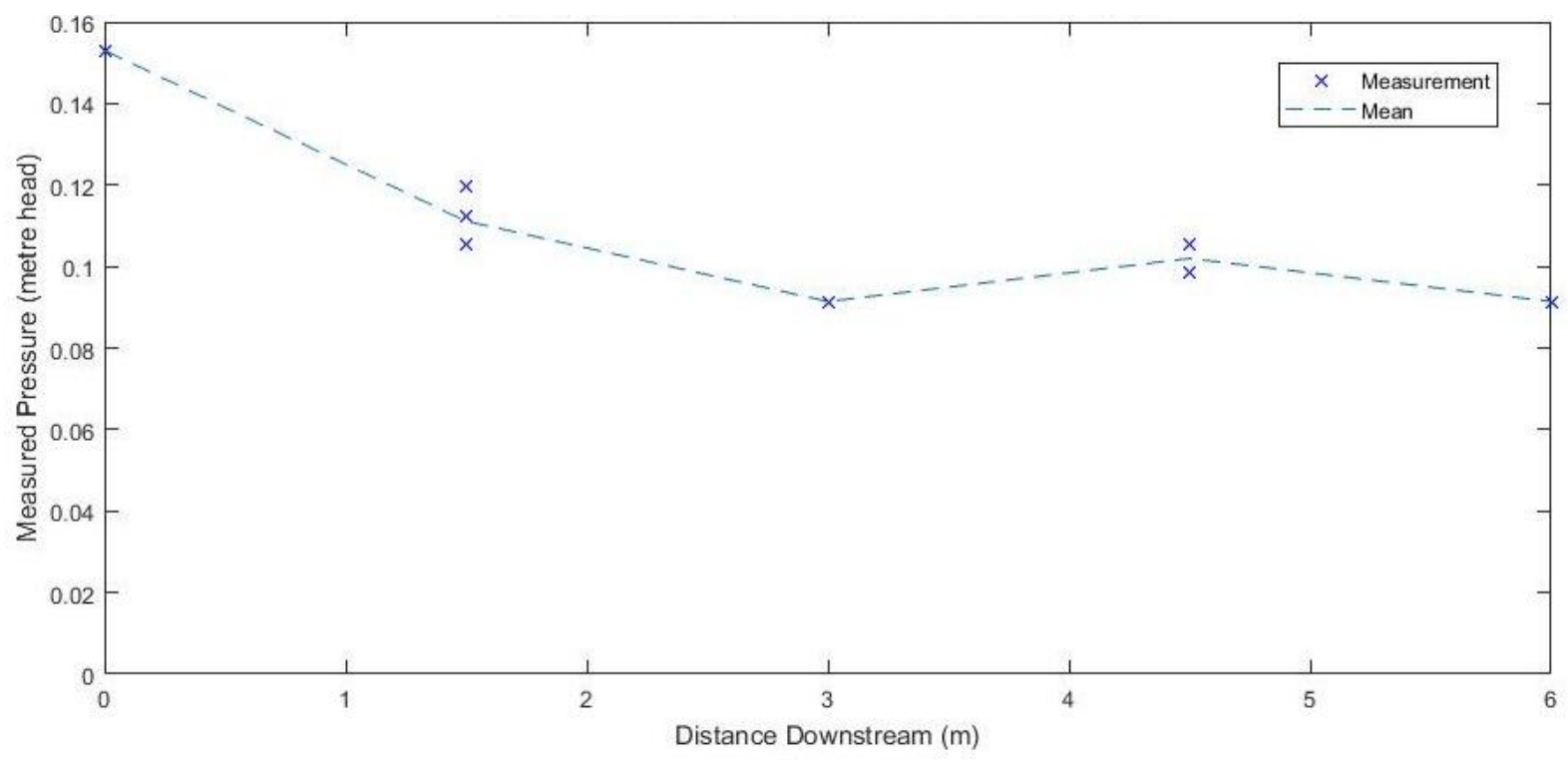

Figure 81. Hydraulic Gradient for Flow Rate of $8.8 \mathrm{~L} / \mathrm{s}$ 


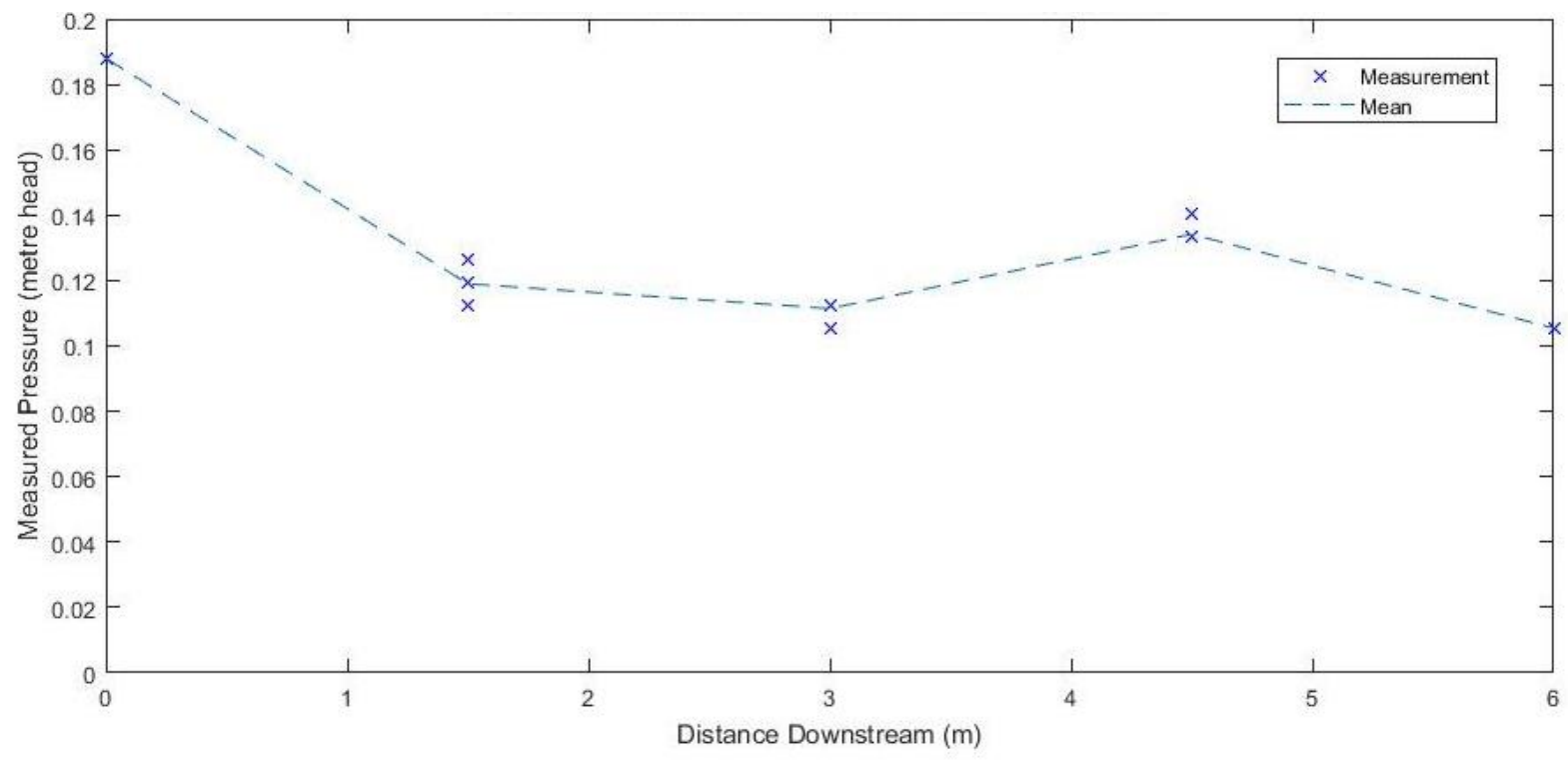

Figure 82. Hydraulic Gradient for Flow Rate of 10.28L/s

Due to the limitation of the pump, the level in the upstream water tank only exceeded the top of the pipe by approximately $20 \mathrm{~mm}$ and the pipe was never full. Therefore, the results for the experiments were only valid for exfiltration under gravitational conditions only.

Judging by the recorded hydraulic profile, the perforated pipe will evenly distribute runoff in larger events producing at a flow of at least $4 \mathrm{~L} / \mathrm{s}$, while smaller storm will not be evenly distributed.

Minor surcharge was observed at inflow rate of $10.28 \mathrm{~L} / \mathrm{s}$, and assuming each of the four sides of the distribution loop receive the same amount of water, the maximum exfiltration capacity of the distribution pipe system is $41.12 \mathrm{~L} / \mathrm{s}$.

Using the method shown in Equation 10.

$$
i=\frac{Q}{C A}=\frac{\frac{0.04112 \mathrm{~m}^{3}}{s} * \frac{3600 \mathrm{~s}}{\mathrm{hr}}}{0.95 * 1074 \mathrm{~m}^{2}}=137.8 \mathrm{~mm} / \mathrm{hr}
$$

Where

$Q$ is the inflow rate, taken as $41.12 \mathrm{~L} / \mathrm{s}$ or $0.04112 \mathrm{~m}^{3} / \mathrm{s}$ 
$C$ is the runoff coefficient, taken as 0.95 for concrete or asphalt surface which makes up the majority of catchment area

$A$ is the area of the catchment, which is $1074 \mathrm{~m}^{2}$ as per section 3.1 .1 .

$i$ is the intensity of the storm event which will produce the peak flow $Q$

However, surcharge was frequently observed even at lower rainfall intensities in the field. This suggesting other factors could be the limiting factors in exfiltration rate. These factors could include the reduction of soil permeability after years of service, accumulation of fine particulates in the pipe, clogging of the pipe, or uneven settlement of the pipe in the soil. These all could cause an uneven distribution of stormwater within the loop.

Though initial modelling suggests the pipe size should suffice, additional factors discussed above should be considered during the design process. Further investigation of current condition of the pipe in the field should be investigated to pinpoint the exact cause of the discrepancy between current theory and practice. 


\section{Conclusions and Recommendations}

\subsection{Conclusion}

Concentration reduction performance comparison between traditional bioretention cells and soil cell showed both LID systems performed well, which suggest the current design guideline for soil cell is adequate. However, this thesis is only one datapoint and additional studies are needed to support this conclusion.

The water quantity measurements were unreliable; however, it should be noted volume control is not an excepted function of the soil cell at Queensway as the soil medium is enclosed in an impermeable geotextile in order to comply with local regulation which prohibits infiltration at pollution hot spots. As the reviewed literature on traditional bioretention cells have demonstrated, infiltration accounted for reduction of over $80 \%$ of runoff volume even in low permeability soil (Khan et al. 2012a; Van Seters 2014); this component of water balance did not exist for the cell studied in the thesis. The soil water level measurement does not suggest significant water retention in the cell.

\subsection{Design Recommendation}

As mentioned in 4.1.3, a permanent saturated layer with overdrain can effectively reduce nitrate concentration as it creates an anoxic condition; this may be considered in future iterations of this device. Literature has suggested a combination of a permanently saturated zone, as shown in Figure 6 in 2.1.1, and organic content have performed well in nitrate removal in laboratory conditions even after a long dormant period (Kim et al. 2003). 
As discussed in section 4.2, the flow rate of $10.28 \mathrm{~L} / \mathrm{s}$ has caused a surcharging of the pipe; this flow rate roughly corresponds to the peak flow resulting from a rainfall intensity of $40 \mathrm{~mm} / \mathrm{hr}$ as per calculation using Rational Method. This intensity is roughly equivalent to a 25-minute event of a 2-year return period. This could suggest the current design is insufficient for higher intensity storms even under ideal conditions.

The year of 2016 had been an abnormally dry year and rainfall events were all below the 2-year return period, and the frequent surge observed could suggest the limitation was not at the pipe. The permeability of the soil or particulate and detritus accumulation in the pipe could have impeded the exfiltration performance of the perforated pipe. Additional field investigation may be required.

Sizing guideline was mentioned as a possible knowledge gap, however, the abnormally dry 2016 prevents a proper assessment of the soil cell's hydrologic performance under normal conditions. Therefore, no conclusions or recommendations will be provided on this subject.

\subsection{Future Research}

With regards to the monitoring operation, significant improvement can be made. It is observed that the frequent backlog of water and surges over top of the weir invalidates the results of inflow measurements. Alternative flow rate monitoring method should be considered. The flow velocity and flow depth should both be measured such that the flow rate can be calculated by multiplying the flow cross-sectional area with the flow velocity. Having an accurate measurement of flow rate allows for the adoption of flow portioned sampling technique.

Even if the flow rate is not calculated in real time, a flow portioned composite sample still could be produced post hoc. By processing the flow data prior to making the composite sample, the 
portion of total flow represented by each sample bottle could be calculated. The composite sample should be comprised of a volume from each aliquot sample proportional to the flow volume.

The intra-event temporal distribution of runoff quality for this site is not studied, therefore the first flush characteristics for this catchment is not available. The analysis of each aliquot sample would provide data to study the first-flush characteristic of different pollutants and further inform the next iteration of the soil design. The finer portion of TSS is responsible for a disproportionally high portion of pollutants. However, no PSD analysis were conducted for the TSS in runoff in this study. It would be beneficial to analyze the PSD in the runoff of certain events, particularly the influent and effluent in winter where TSS, metal, and phosphorus concentration increased.

The soil cell has been in service for approximately 7 to 8 years without maintenance, and the current state of soil is unknown; samples of the soil could provide the accumulation rate of the pollutants, which could be useful in determining maintenance requirements. Soil permeability test can provide the necessary data for modelling the soil cell's capability for attenuation. The condition of the perforated pipe is also unknown. Debris from the streets and soil particulates may have accumulated in the pipe, impeding the exfiltration capacity. A survey of the pipe in the current condition is needed to establish the maintenance requirement. Numerical modelling of exfiltration capacity of perforated pipe can be developed from the result of reported in 4.2 . 
Appendix I

\section{Engineering Drawings of the Soil Cell}

(By Dr. James Li) 


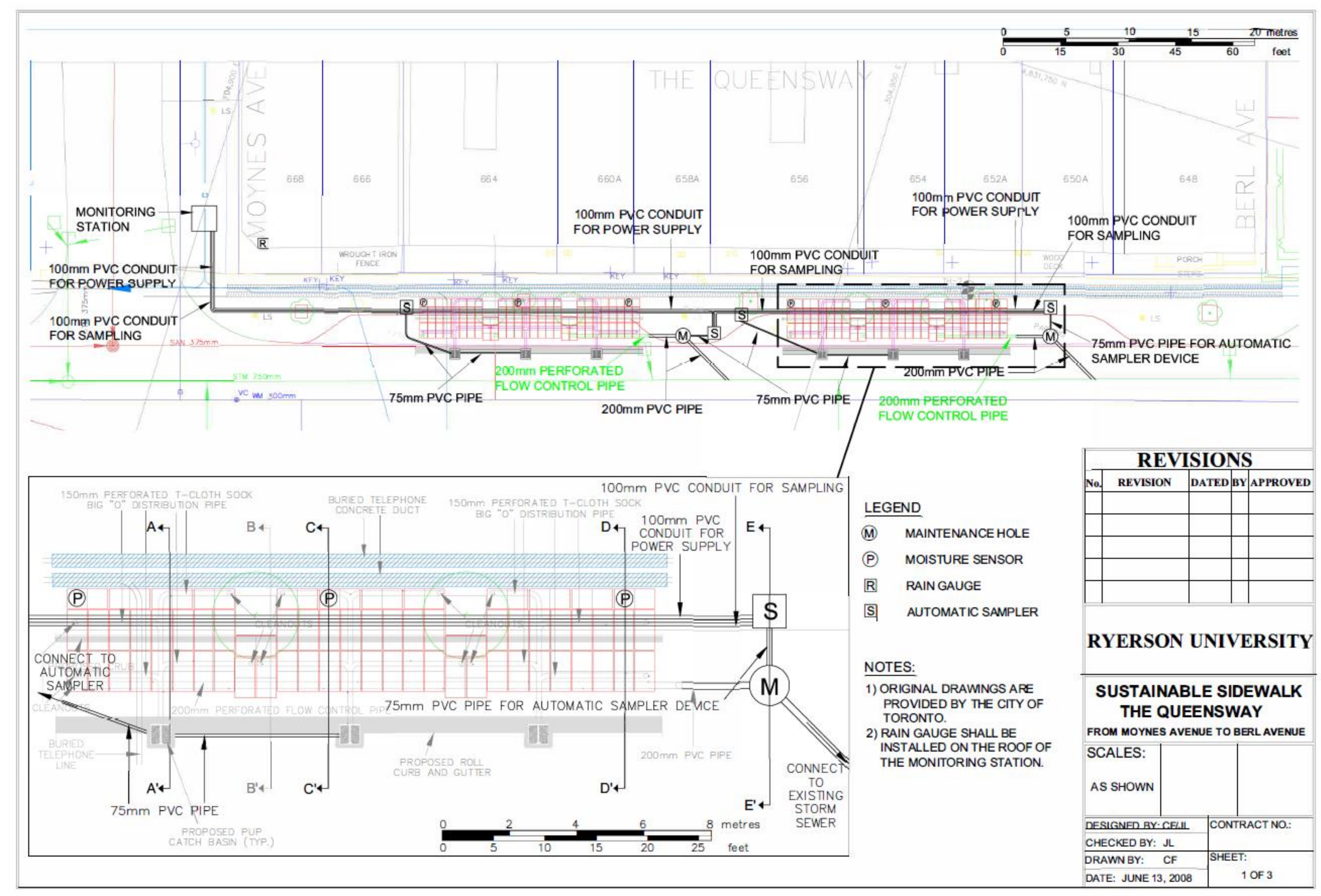




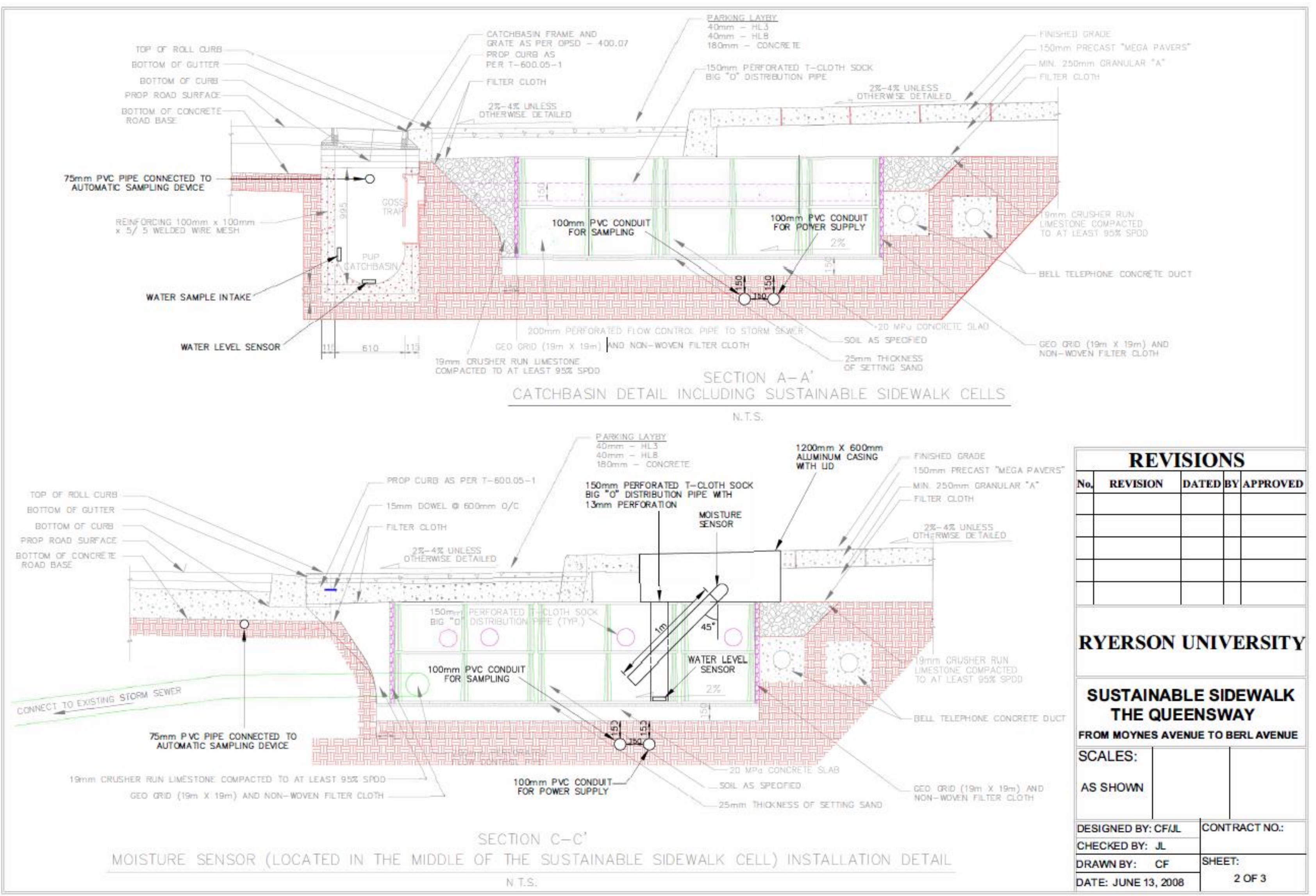




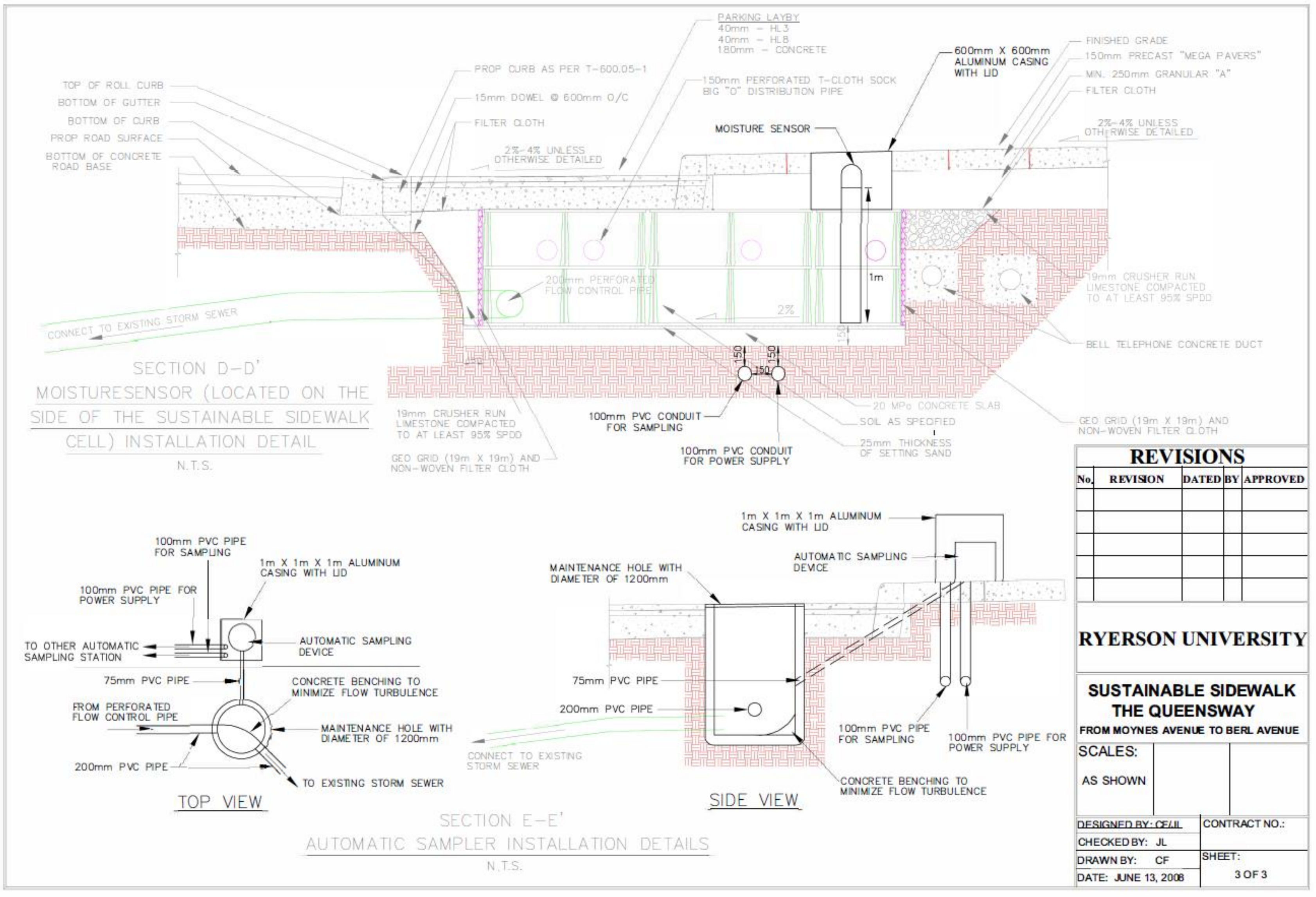




\section{Appendix II \\ Monitoring Plan}

(Written by Marija Eric) 


\section{Queensway Sustainable Sidewalk Study: Instructions on How to Conduct Main Activities}

\section{(1) Site Work:}

\section{Directions to the Site:}

Site Location: 660 The Queensway, Etobicoke, Toronto, Ontario (corner of "The Queensway" \& Moynes Ave. - between Moynes Ave. and Berl Ave. on the north side of The Queensway) Nearest major intersection: The Queensway \& Royal York Rd.

Nearest TTC stop: Royal York (take a bus south on Royal York Rd. to The Queensway and walk a few blocks east to Moynes Ave. where a concrete "hut" with graffiti on it is situated on the corner)

Introduction:

Three sheds with autosampler machines are located on the sidewalk on the north side of The Queensway between Moynes Avenue and Berl Avenue. The first shed on the western side is unused and acts as a control. The middle shed contains the autosampler which collects inflowing stormwater runoff coming from the street and surrounding area. This autosampler is known as the inlet machine and collects water that has not yet travelled through the sustainable sidewalk system constructed beneath the sidewalk. This water is generally expected to contain the highest concentration levels of pollutants because it has not yet been cleaned by the underground system. After the water travels through the underground sustainable sidewalk system, it will be filtered by the surrounding soil. Therefore, the water collected on the east end or outlet side of the system is expected to be cleaner or contain lower levels of concentrations of pollutants than at the inlet side. The shed on the east end contains the outlet autosampler which collects the water after passing through the system. This water is expected to contain lower concentration levels of pollutants than the water collected by the inlet autosampler. Water samples collected at both the inlet and the outlet are taken to the lab to be prepared for submission. After submission, the 
samples are analyzed by the lab and the results for the inlet and the outlet are sent to us for comparison and analysis.

\section{Site Instructions:}

1. Drop off any extra, empty bottles in the hut, if applicable.

2. Go to the middle shed first - this is the shed that contains the inlet autosampler.

Note: Always check the inlet autosampler first and the outlet autosampler second.

3. Unlock the handles of the shed.

Note: The handles can be a little bit stiff and difficult to move but they must be locked properly at the end of every site visit. They are situated in the vertical position when they are locked properly and in the horizontal position when they are unlocked.

4. Open the shed and note what is said on the initial screens of the inlet autosampler. Write down everything that is seen word-for-word. Also note any other unusual or interesting observations in your field notes.

5. Unlatch the top part of the inlet autosampler to open the machine.

6. Note how many bottles have some sample collected. The number of each bottle is located on the side of the metal carousel holding the bottles. Also note how full each bottle is and the appearance of the water in the bottles.

7. If any water was collected, remove the bottle(s) from the carousel and replace it with an empty bottle(s). If most or all bottles are partly or almost full, remove the carousel with the bottles from the autosampler and replace it with a carousel containing an empty set of bottles. The carousel is placed securely in the autosampler by moving the carousel around until a "click" noise is heard. The space at the bottom of the carousel must connect with the metal piece sticking out of the bottom of the inside of the autosampler machine in order for it to be securely in place.

Note: Each autosampler bottle should line up with a corresponding number on the outside of the carousel. The number should be centred along the wider side of each carousel bottle. The autosampler bottles should be placed neatly and firmly within the carousel.

8. Each carousel contains 14 autosampler bottles, each of which can hold up to $950 \mathrm{~mL}$ of sampled water. Place an appropriately labelled cap on each bottle that contains a sample and place them in the fridge of the hut. 
9. Once the carousel is firmly in place, close the top of the autosampler machine and reconnect the latch on the side so that it is secure.

10. Write down the sampling report that is found by manually scrolling through the screens of the autosampler machine. The steps to scroll through the screens to reach the sampling report are as follows:

(1) Press the red "stop" button to make sure that the machine is completely stopped.

(2) Select "View Report" and then press “enter" (yellow button with arrow).

(3) Select "View Data" and then press "enter".

(4) Select "View Sampling Report" and then press "enter".

Note: The autosampler shows the sampling report by presenting the date and time of collection of each bottle individually. The sampling report must be copied down by pen and paper before being downloaded so that there is a paper version of the information which can also be found in the report file that can be downloaded by a computer/laptop.

11. After writing down the sampling report, connect the interrogator cable to the middle circular connection point on the autosampler that is located on the back of the top part of the machine, behind the screens. There is a sketch of a laptop beside the connection point indicating that this is where laptops should be connected.

Note: In order to connect the interrogator cable to a laptop, it must first be connected to a serial-to-USB adaptor cable which can then be inserted into a USB port on a laptop.

Software must first be installed on the laptop to install the adaptor cable so that the laptop recognizes this type of hardware.

12. Once the interrogator and adaptor cables are connected to the laptop, open the Flowlink software program to create a site and download the data. Steps for creating a site are found on page 153 of the Flowlink software manual and steps to downloading the data can be given as a separate set of instructions upon request.

13. Once the data has been retrieved by the Flowlink software program, it is stored within an internal database and can be saved or exported to the laptop on-site or off-site. It is recommended that the sampling report for the inlet and outlet be saved on-site and compared with the written sampling reports. All other data sets (sample event, flow level, and fridge temperature) can be exported to the laptop off-site at a later time. 
14. Once the data has been retrieved and the sampling report has been saved, the inlet autosampler machine must be re-set so that it is ready for the next event. The steps for re-setting the machine are as follows:

(1) Press the red "stop" button to make sure the machine is completely stopped.

(2) Select "run Queensway1" (or "run Queensway2" for the outlet machine).

(3) Press the yellow "enter" button and wait a few seconds to make sure it is reset.

Note: Once an autosampler is re-set, the current sampling report cannot be obtained from the screen anymore so write down the sampling report shown on the screen before re-setting the machine.

15. After re-setting the inlet autosampler machine, follow the same procedure at the outlet autosampler machine by repeating steps 1-13.

16. Sometimes, the data of the on-site rain gauge must be downloaded. This is done by unlocking the rain gauge box and connecting a cable inside the box to a USB pendant data logger which connects to a laptop. Once the laptop is connected, Hoboware software is used to download the rain gauge data which is then exported in table format.

\section{(2) Lab Work:}

Directions to the Lab: The lab is a City of Toronto Water Laboratory located at 545

Commissioners Street in the east end of Toronto near Kew Beach.

1. Once the autosampler bottles arrive at the lab, they must be transported from the car(s) upstairs to the "Wet Chem" lab room on the second floor. It is not permissible to carry them up the stairs anymore so first go up to the second floor, sign in, and then send a cart down to the first floor via the elevator.

Note: You must sign in and out of the lab before and after every lab visit.

2. Transfer the buckets of autosampler bottles from the car(s) to the cart and then send the cart upstairs to the second floor via the elevator. The bottles have a tendency to fall in the car trunk and on the cart so try to align them so that they are in a stable, upright position. 
3. Line the bottles up in chronological order for each set of inlet and outlet bottles and take a picture of them, if possible.

4. A composite sample for each set of inlet and outlet bottles will be made by taking an equal proportion of sample from each autosampler bottle to fill a glass jug that can hold up to 1 US-gal or $3.79 \mathrm{~L}$ of water. For example, if all 14 bottles collected from the inlet autosampler machine are full or almost completely full then $250 / 275 \mathrm{~mL}$ of sample can be collected from each bottle to create a composite sample of 3.50/3.85 L of water.

The proportion taken from each autosampler bottle may vary according to the amount of sample in each bottle but try to take an equal amount from each bottle, if possible. After determining the amount to be taken from each autosampler bottle, shake each bottle, measure the amount taken from each bottle separately in a glass cylinder and then pour it into the glass jug.

Note: Each autosampler bottle must be shaken well before pouring the selected proportion into the glass cylinder.

5. Two glass jugs, one for the inlet and one for the outlet, will be made and placed side-byside for a photograph to compare the sample "before" and "after" it has been treated by the system.

Note: It is important to shake the glass jugs well before creating the sample tests.

6. The lab submission sheet contains a list of the required sample tests for submission. The number of sample tests submitted will depend on the amount of sample collected by each autosampler. Pre-printed labels with "fill-in-the-blank" spaces are brought to the lab, "filled in", and placed on the appropriate bottles for the sample tests. For unfiltered sample tests, just shake the composite sample jug and either fill in the sample test bottle directly or measure the appropriate amount in a glass cylinder and pour it into the sample test bottle (a funnel may be used).

For filtered sample tests, shake the composite sample and measure the appropriate amount in a glass cylinder. Connect a glass flask to a suction pump on the sink and place a stopper with filter

paper on top of the flask using tongs (tweezers). Fasten a plastic, cup-like object with no bottom to the stopper with filter paper on top and turn on the suction pump. Begin pouring in the measured, sampled amount until the filter paper becomes visibly saturated with dirt particles. 
Once the filter paper is saturated, turn off the suction pump, wash the stopper, replace the filter

paper, fasten the plastic object on top, and turn on the suction pump once again. The replacement

of the saturated filter paper can be repeated as many times as necessary until the sample test is completed. Always try to turn the vacuum off just before all of the water being filtered has passed through the stopper with filter paper. Do not wait until after all of the water has passed through the stopper and filter paper to turn off the suction pump. After all of the measured sample has been filtered, pour the filtered sample from the glass flask into the appropriately labelled sample test bottle (a funnel may be used).

7. The sample can be submitted to the lab after preparing all of the sample test bottles and filling in the corresponding sample submission sheet. A copy of the submission sheet is made by the lab and received before leaving the lab.

\section{(3) Data Analysis}

Rainfall and flow level data must be analyzed for each event (rain/snow) to create a table with the following characteristics for each event: rainfall depth from multiple sources, duration, peak intensity, inlet and outlet maximum flow levels, flow rate, and time between peak flow as well as others potentially. Graphs illustrating flow level/rate and rainfall (on the same graph) versus time must also be developed. 


\section{Appendix III}

Inlet Thel-mar Weir Curve 


\section{8 inch THEL-MAR CO. VOLUMETRIC WEIR DISCHARGE TABLE Manufactured by Thel-Mar Co. (Data from Thel-Mar Co.)}

Formulas: $\mathrm{CFS}=\mathrm{GPS} \times 0.1337 \quad$ LPS $=$ GPS $\times 3.785$

\begin{tabular}{|c|c|c|c|c|c|c|c|c|}
\hline $\begin{array}{c}\text { HEAD } \\
\text { FEET }\end{array}$ & $\begin{array}{c}\text { HEAD } \\
(\mathrm{MM})\end{array}$ & CFS & GPS & GPM & GPD & MGD & LPS & $\mathrm{CMH}$ \\
\hline 0.016 & 51 & 0.0001 & 0.0007 & 0.0396 & 57 & 0.0001 & 0.0025 & 0.0090 \\
\hline 0.023 & 7 & 0.0002 & 0.0013 & 0.0799 & 115 & 0.0001 & 0.0050 & 0.0181 \\
\hline 0.030 & 9 & 0.0004 & 0.0030 & 0.1806 & 260 & 0.0003 & 0.0114 & 0.0410 \\
\hline 0.036 & 11 & 0.0007 & 0.0054 & 0.3222 & 464 & 0.0005 & 0.0203 & 0.0732 \\
\hline 0.043 & 13 & 0.0011 & 0.0085 & 0.5104 & 735 & 0.0007 & 0.0322 & 0,1159 \\
\hline 0.049 & 15 & 0.0016 & 0.0123 & 0.7389 & 1,064 & 0.0011 & 0,0466 & 0.1678 \\
\hline 0.056 & 17 & 0.0023 & 0.0169 & 1.0125 & 1,458 & 0.0015 & 0.0639 & 0.2300 \\
\hline 0.062 & 19 & 0.0030 & 0.0222 & 1.3306 & 1.916 & 0.0019 & 0.0839 & 0.3022 \\
\hline 0.069 & 21 & 0.0038 & 0.0282 & 1.6944 & 2,440 & 0.0024 & 0.1069 & 0.3849 \\
\hline 0.075 & 23 & 0.0047 & 0.0351 & 2.1056 & 3.032 & 0.0030 & 0,1328 & 0.4783 \\
\hline 0.082 & 25 & 0.0057 & 0.0427 & 2.5618 & 3,689 & 0.0037 & 0.1616 & 0.5819 \\
\hline 0.089 & 27 & 0.0073 & 0.0543 & 3.2569 & 4,690 & 0.0047 & 0.2055 & 0.7398 \\
\hline 0.095 & 29 & 0.0085 & 0.0633 & 3.8007 & 5,473 & 0.0055 & 0.2398 & 0.8633 \\
\hline 0.102 & 31 & 0.0113 & 0.0845 & 5.0701 & 7,301 & 0.0073 & 0.3198 & 1.1517 \\
\hline 0.108 & 33 & 0.0143 & 0.1070 & 6.4188 & 9,243 & 0.0092 & 0.4049 & 1.4580 \\
\hline 0.115 & 35 & 0.0175 & 0.1307 & 7.8403 & 11.290 & 0.0113 & 0.4946 & 1.7809 \\
\hline 0.121 & 37 & 0.0208 & 0.1558 & 9.3472 & 13,460 & 0.0135 & 0.5897 & 2.1232 \\
\hline 0.128 & 39 & 0.0243 & 0.1821 & 10.9236 & 15,730 & 0.0157 & 0.6891 & 2.4813 \\
\hline 0,135 & 41 & 0.0280 & 0.2096 & 12.5764 & 18.110 & 0.0181 & 0.7934 & 2.8568 \\
\hline 0.141 & 43 & 0.0319 & 0.2383 & 14.2986 & 20.590 & 0.0206 & 0.9020 & 3.2480 \\
\hline 0.148 & 45 & 0.0359 & 0.2682 & 16.0903 & 23.170 & 0.0232 & 1.0150 & 3.6550 \\
\hline 0.154 & 47 & 0.0400 & 0.2993 & 17.9583 & 25,860 & 0.0259 & 1.1329 & 4.0793 \\
\hline 0.161 & 49 & 0.0443 & 0.3315 & 19.8889 & 28,640 & 0.0286 & 1.2547 & 4.5178 \\
\hline 0.167 & 51 & 0.0488 & 0.3648 & 21.8889 & 31.520 & 0.0315 & 1.3808 & 4.9721 \\
\hline 0.174 & 53 & 0.0534 & 0.3992 & 23.9514 & 34,490 & 0.0345 & 1.5109 & 5.4406 \\
\hline 0.180 & 55 & 0.0581 & 0.4346 & 26.0764 & 37,550 & 0.0376 & 1.6450 & 5.9233 \\
\hline 0.187 & 57 & 0.0630 & 0.4712 & 28.2708 & 40,710 & 0.0407 & 1.7834 & 6.4218 \\
\hline 0.194 & \begin{tabular}{l|l}
59 & \\
\end{tabular} & 0.0680 & 0.5087 & 30.5208 & 43.950 & 0.0440 & 1.9254 & 6.9329 \\
\hline 0.200 & 61 & 0.0732 & 0.5472 & 32.8333 & 47,280 & 0.0473 & 2.0712 & 7.4582 \\
\hline 0.207 & 63 & 0.0784 & 0.5867 & 35.2014 & 50,690 & 0.0507 & 2.2206 & 7.9961 \\
\hline 0.213 & 65 & 0.0838 & 0.6271 & 37.6250 & 54,180 & 0.0542 & 2.3735 & 8.5466 \\
\hline 0.220 & 67 & 0.0894 & 0.6685 & 40.1111 & 57,760 & 0.0578 & 2.5303 & 9.1114 \\
\hline 0.226 & 69 & 0.0950 & 0.7108 & 42.6458 & 61,410 & 0.0614 & 2.6902 & 9.6871 \\
\hline 0.233 & 71 & 0.1008 & 0.7539 & 45.2361 & 65.140 & 0.0651 & 2.8536 & 10.2755 \\
\hline 0.240 & 73 & 0.1067 & 0.7979 & 47.8750 & 68.940 & 0.0689 & 3.0201 & 10.8749 \\
\hline 0.246 & 75 & 0.1127 & 0.8427 & 50.5625 & 72.810 & 0.0728 & 3.1897 & 11.4854 \\
\hline 0.253 & 77 & 0.1188 & 0.8884 & 53.3056 & 76.760 & 0.0768 & 3.3627 & 12.1085 \\
\hline 0.259 & 79 & 0.1250 & 0.9348 & 56.0903 & 80.770 & 0.0808 & 3.5384 & 12.7411 \\
\hline 0.266 & 81 & 0.1313 & 0.9821 & 58.9236 & 84.850 & 0.0849 & 3.7171 & 13.3847 \\
\hline 0.272 & 83 & 0.1377 & 1.0300 & 61.7986 & 88,990 & 0.0890 & 3.8985 & 14.0377 \\
\hline 0.279 & 85 & 0.1442 & 1.0786 & 64.7153 & 93.190 & 0.0932 & 4.0825 & 14.7003 \\
\hline 0.285 & 87 & 0.1508 & 1.1280 & 67.6806 & 97,460 & 0.0975 & 4.2695 & 15.3738 \\
\hline 0.292 & 89 & -0.1575 & 1.1780 & 70.6806 & 101,780 & 0.1018 & 4.4588 & 16.0553 \\
\hline 0.299 & 91 & 0.1643 & 1.2287 & 73.7222 & 106,160 & 0.1062 & 4.6506 & 16.7462 \\
\hline 0.305 & 93 & 0.1711 & 1.2800 & 76.7986 & 110.590 & 0.1106 & 4.8447 & 17.4450 \\
\hline 0.312 & 95 & 0.1781 & 1.3318 & 79.9097 & 115.070 & 0.1151 & 5.0410 & 18.1517 \\
\hline 0.318 & 97 & 0.1851 & 1.3844 & 83.0625 & 119.610 & 0.1196 & 5.2399 & 18.8679 \\
\hline 0.325 & 99 & 0.1922 & 1.4374 & 86.2431 & 124.190 & 0.1242 & 5.4405 & 19.5903 \\
\hline & & & & & & & & \\
\hline
\end{tabular}


Appendix IV

\section{Outlet Weir Curve}




\begin{tabular}{cccccc} 
& \\
V-notch weirs & Thin Plate Free-Flow Discharge Table & & & & \\
\hline & GPI & M GD & CFS & l/s & m3/hr \\
\hline Weir Angle & $223 \mathrm{H}^{2.5}$ & $0.321 \mathrm{H}^{2.5}$ & $0.497 \mathrm{H}^{2.5}$ & $274 \mathrm{H}^{2.5}$ & $988 \mathrm{H}^{2.5}$ \\
\hline 22.5 Degree & $303 \mathrm{H}^{2.5}$ & $0.437 \mathrm{H}^{2.5}$ & $0.676 \mathrm{H}^{2.5}$ & $373 \mathrm{H}^{2.5}$ & $1304 \mathrm{H}^{2.5}$ \\
\hline 30 Degree & $465 \mathrm{H}^{2.5}$ & $0.669 \mathrm{H}^{2.5}$ & $1.04 \mathrm{H}^{2.5}$ & $571 \mathrm{H}^{2.5}$ & $2060 \mathrm{H}^{2.5}$ \\
\hline 45 Degree & $648 \mathrm{H}^{2.5}$ & $0.9333 \mathrm{H}^{2.5}$ & $1.44 \mathrm{H}^{2.5}$ & $797 \mathrm{H}^{2.5}$ & $2870 \mathrm{H}^{2.5}$ \\
\hline 60 Degree & $1120 \mathrm{H}^{2.5}$ & $1.62 \mathrm{H}^{2.5}$ & $2.50 \mathrm{H}^{2.5}$ & $1308 \mathrm{H}^{2.5}$ & $4970 \mathrm{H}^{2.5}$ \\
\hline 120 Degree & $1904 \mathrm{H}^{2.5}$ & $2.80 \mathrm{H}^{2.5}$ & $4.33 \mathrm{H}^{2.5}$ & $2390 \mathrm{H}^{2.5}$ & $8610 \mathrm{H}^{2.5}$ \\
\hline
\end{tabular}




\section{Appendix V}

Water Sample Summary 


\begin{tabular}{|c|c|c|c|c|c|c|c|c|c|c|c|}
\hline \multirow{2}{*}{ Events } & \multicolumn{11}{|c|}{ Influent Concentration } \\
\hline & $\mathrm{Al}(\mathrm{mg} / \mathrm{L})$ & $\mathrm{BOD}(\mathrm{mg} / \mathrm{L})$ & $\mathrm{Cl}(\mathrm{mg} / \mathrm{L})$ & $\mathrm{Cu}(\mathrm{mg} / \mathrm{L})$ & $\mathrm{Fe}(\mathrm{mg} / \mathrm{L})$ & $\mathrm{Pb}(\mathrm{mg} / \mathrm{L})$ & $\mathrm{Ni}(\mathrm{mg} / \mathrm{L})$ & Nitrate(mg/L) & $\mathrm{TP}(\mathrm{mg} / \mathrm{L})$ & $\mathrm{TSS}(\mathrm{mg} / \mathrm{L})$ & $\mathrm{Zn}(\mathrm{mg} / \mathrm{L})$ \\
\hline 2016-01-08 & $2.32 \mathrm{E}-01$ & $4.00 \mathrm{E}+00$ & $1.95 \mathrm{E}+03$ & 7.87E-03 & $1.67 \mathrm{E}+00$ & 2.19E-03 & $1.69 \mathrm{E}-03$ & 3.00E-02 & 5.27E-02 & $8.00 \mathrm{E}+00$ & $4.88 \mathrm{E}-02$ \\
\hline \multicolumn{12}{|l|}{ 2016-01-09 } \\
\hline 2016-01-10 & $3.48 \mathrm{E}+00$ & $1.40 \mathrm{E}+01$ & $7.05 E+02$ & $6.20 \mathrm{E}-02$ & $6.77 \mathrm{E}+00$ & $2.84 \mathrm{E}-02$ & $7.29 \mathrm{E}-03$ & $3.60 \mathrm{E}-01$ & $3.25 \mathrm{E}-01$ & $1.15 \mathrm{E}+02$ & $5.00 \mathrm{E}-01$ \\
\hline 2016-02-02 & $1.91 \mathrm{E}+00$ & $3.70 \mathrm{E}+01$ & $2.15 \mathrm{E}+03$ & $4.73 \mathrm{E}-02$ & $4.10 \mathrm{E}+00$ & 1.57E-02 & $7.18 \mathrm{E}-03$ & $2.70 \mathrm{E}-01$ & $2.66 \mathrm{E}-01$ & $9.40 \mathrm{E}+01$ & 1.89E-01 \\
\hline \multicolumn{12}{|l|}{$2016-02-16$} \\
\hline 2016-02-19 & $3.05 E+00$ & $4.70 \mathrm{E}+01$ & $8.10 \mathrm{E}+03$ & $7.72 \mathrm{E}-02$ & $1.21 \mathrm{E}+01$ & $2.62 \mathrm{E}-02$ & $1.52 \mathrm{E}-02$ & $2.75 \mathrm{E}-01$ & $4.85 \mathrm{E}-01$ & $2.00 \mathrm{E}+02$ & 5.00E-01 \\
\hline \multicolumn{12}{|l|}{ 2016-02-24 } \\
\hline 2016-03-04 & $1.20 \mathrm{E}+00$ & $6.00 \mathrm{E}+00$ & $1.27 \mathrm{E}+04$ & $3.70 \mathrm{E}-02$ & $3.37 E+00$ & $1.28 \mathrm{E}-02$ & $1.35 \mathrm{E}-02$ & $5.50 \mathrm{E}-01$ & $1.75 \mathrm{E}-01$ & $6.80 \mathrm{E}+01$ & $1.61 \mathrm{E}-01$ \\
\hline 2016-03-10 & $5.42 \mathrm{E}+00$ & $1.30 \mathrm{E}+01$ & $4.43 E+03$ & 7.33E-02 & $9.85 \mathrm{E}+00$ & $4.02 \mathrm{E}-02$ & $1.40 \mathrm{E}-02$ & $8.20 \mathrm{E}-01$ & 3.87E-01 & $2.12 \mathrm{E}+02$ & $1.00 \mathrm{E}+00$ \\
\hline 2016-03-14 & $2.37 \mathrm{E}+00$ & $7.00 \mathrm{E}+00$ & $8.75 \mathrm{E}+02$ & 3.77E-02 & $3.95 \mathrm{E}+00$ & $1.63 \mathrm{E}-02$ & $5.68 \mathrm{E}-03$ & $5.50 \mathrm{E}-01$ & $2.05 \mathrm{E}-01$ & $1.12 \mathrm{E}+02$ & $1.59 \mathrm{E}-01$ \\
\hline 2016-03-15 & $1.42 \mathrm{E}+00$ & $7.00 \mathrm{E}+00$ & $1.52 \mathrm{E}+02$ & $2.83 \mathrm{E}-02$ & $2.48 \mathrm{E}+00$ & $9.39 \mathrm{E}-03$ & $3.45 \mathrm{E}-03$ & $5.50 \mathrm{E}-01$ & $1.60 \mathrm{E}-01$ & $4.60 \mathrm{E}+01$ & $1.43 \mathrm{E}-01$ \\
\hline 2016-03-16 & $4.50 \mathrm{E}+00$ & $6.00 \mathrm{E}+00$ & $3.06 \mathrm{E}+02$ & $4.86 \mathrm{E}-02$ & $7.27 \mathrm{E}+00$ & $2.63 \mathrm{E}-02$ & 7.70E-03 & $1.10 \mathrm{E}+00$ & $3.62 \mathrm{E}-01$ & $2.58 \mathrm{E}+02$ & $5.00 \mathrm{E}-01$ \\
\hline 2016-03-23 & $3.72 \mathrm{E}-01$ & $2.00 \mathrm{E}+00$ & $2.06 \mathrm{E}+02$ & $3.45 \mathrm{E}-02$ & $5.27 \mathrm{E}-01$ & $1.35 \mathrm{E}-03$ & 4.57E-03 & $7.80 \mathrm{E}-01$ & $2.79 \mathrm{E}-01$ & $4.00 \mathrm{E}+00$ & $3.54 \mathrm{E}-02$ \\
\hline 2016-03-31 & $9.91 \mathrm{E}-01$ & $5.00 \mathrm{E}+00$ & $8.63 E+02$ & $2.85 \mathrm{E}-02$ & $1.45 \mathrm{E}+00$ & $6.56 \mathrm{E}-03$ & 3.17E-03 & $1.10 \mathrm{E}+00$ & $1.20 \mathrm{E}-01$ & $2.00 \mathrm{E}+01$ & 8.87E-02 \\
\hline \multicolumn{12}{|l|}{ 2016-04-04 } \\
\hline \multicolumn{12}{|l|}{ 2016-04-06 } \\
\hline 2016-04-25 & $2.35 \mathrm{E}-01$ & $4.00 \mathrm{E}+00$ & $5.43 E+02$ & $2.58 \mathrm{E}-02$ & $2.68 \mathrm{E}-01$ & $6.12 \mathrm{E}-04$ & $4.15 \mathrm{E}-03$ & $1.13 \mathrm{E}+00$ & $1.33 \mathrm{E}-01$ & $2.00 \mathrm{E}+00$ & $3.16 \mathrm{E}-02$ \\
\hline 2016-05-26 & $1.43 \mathrm{E}+00$ & $3.90 \mathrm{E}+01$ & $7.53 \mathrm{E}+01$ & $5.79 \mathrm{E}-02$ & $3.37 \mathrm{E}+00$ & $1.04 \mathrm{E}-02$ & $5.96 \mathrm{E}-03$ & $5.50 \mathrm{E}-01$ & $5.76 \mathrm{E}-01$ & $8.80 \mathrm{E}+01$ & $1.85 \mathrm{E}-01$ \\
\hline 2016-06-11 & 5.71E-01 & $1.40 \mathrm{E}+01$ & $9.05 \mathrm{E}+00$ & $2.01 \mathrm{E}-02$ & $1.09 \mathrm{E}+00$ & $4.50 \mathrm{E}-03$ & $2.25 \mathrm{E}-03$ & $6.40 \mathrm{E}-01$ & $1.89 \mathrm{E}-01$ & $6.70 \mathrm{E}+01$ & $7.87 \mathrm{E}-02$ \\
\hline 2016-06-26 & 7.92E-01 & $6.80 \mathrm{E}+01$ & $2.28 \mathrm{E}+01$ & $5.78 \mathrm{E}-02$ & $1.82 \mathrm{E}+00$ & $6.94 \mathrm{E}-03$ & $7.38 \mathrm{E}-03$ & $1.15 \mathrm{E}+00$ & $5.42 \mathrm{E}-01$ & $5.20 \mathrm{E}+01$ & $1.88 \mathrm{E}-01$ \\
\hline \multicolumn{12}{|l|}{ 2016-07-01 } \\
\hline \multicolumn{12}{|l|}{ 2016-07-07 } \\
\hline 2016-07-09 & $6.91 \mathrm{E}-01$ & $3.00 \mathrm{E}+01$ & $3.23 \mathrm{E}+01$ & $3.86 \mathrm{E}-02$ & $1.51 \mathrm{E}+00$ & $6.95 \mathrm{E}-03$ & 4.73E-03 & 3.30E-01 & 3.97E-01 & $5.20 \mathrm{E}+01$ & $1.41 \mathrm{E}-01$ \\
\hline 2016-07-14 & $6.65 \mathrm{E}-01$ & $1.70 \mathrm{E}+01$ & $1.45 \mathrm{E}+01$ & $2.15 \mathrm{E}-02$ & $1.13 \mathrm{E}+00$ & $5.22 \mathrm{E}-03$ & $2.65 \mathrm{E}-03$ & $2.75 \mathrm{E}-01$ & $2.22 \mathrm{E}-01$ & $3.60 \mathrm{E}+01$ & 8.92E-02 \\
\hline 2016-07-14 & 5.37E-01 & $8.00 \mathrm{E}+00$ & $1.65 \mathrm{E}+01$ & $1.90 \mathrm{E}-02$ & $8.52 \mathrm{E}-01$ & $4.50 \mathrm{E}-03$ & $2.02 \mathrm{E}-03$ & $2.75 \mathrm{E}-01$ & $1.71 \mathrm{E}-01$ & $3.40 \mathrm{E}+01$ & $6.44 \mathrm{E}-02$ \\
\hline \multicolumn{12}{|l|}{$2016-07-25$} \\
\hline 2016-08-13 & $3.59 \mathrm{E}-01$ & & $5.97 \mathrm{E}+00$ & $2.10 \mathrm{E}-02$ & $6.95 \mathrm{E}-01$ & $4.28 \mathrm{E}-03$ & $2.18 \mathrm{E}-03$ & $2.75 \mathrm{E}-01$ & $1.89 \mathrm{E}-01$ & $2.20 \mathrm{E}+01$ & $6.55 \mathrm{E}-02$ \\
\hline 2016-08-16 & $1.74 \mathrm{E}-01$ & $6.00 \mathrm{E}+00$ & $1.83 \mathrm{E}+01$ & $1.93 \mathrm{E}-02$ & $5.10 \mathrm{E}-01$ & $1.78 \mathrm{E}-03$ & $2.32 \mathrm{E}-03$ & $2.75 \mathrm{E}-01$ & $1.95 \mathrm{E}-01$ & $5.00 \mathrm{E}+00$ & $5.87 \mathrm{E}-02$ \\
\hline \multicolumn{12}{|l|}{ 2016-08-20 } \\
\hline \multicolumn{12}{|l|}{ 2016-08-21 } \\
\hline 2016-08-25 & & & & & & & & & & $2.00 \mathrm{E}+01$ & \\
\hline \multicolumn{12}{|l|}{ 2016-08-25 } \\
\hline 2016-09-07 & $5.55 \mathrm{E}-01$ & $2.00 \mathrm{E}+01$ & $5.21 \mathrm{E}+00$ & $2.43 \mathrm{E}-02$ & $1.16 \mathrm{E}+00$ & $5.23 \mathrm{E}-03$ & $3.21 \mathrm{E}-03$ & $4.00 \mathrm{E}-01$ & $2.28 \mathrm{E}-01$ & $5.20 \mathrm{E}+01$ & $1.06 \mathrm{E}-01$ \\
\hline \multicolumn{12}{|l|}{ 2016-09-10 } \\
\hline 2016-09-17 & & & & & & & & & & & \\
\hline 2016-09-17 & & & & & & & & & & & \\
\hline 2016-09-26 & $5.49 \mathrm{E}-01$ & $1.60 \mathrm{E}+01$ & $6.78 \mathrm{E}+00$ & $2.03 \mathrm{E}-02$ & $1.11 \mathrm{E}+00$ & $4.40 \mathrm{E}-03$ & $2.06 \mathrm{E}-03$ & $2.10 \mathrm{E}-01$ & $1.76 \mathrm{E}-01$ & $3.90 \mathrm{E}+01$ & $8.22 \mathrm{E}-02$ \\
\hline 2016-09-29 & $3.80 \mathrm{E}-01$ & $9.00 \mathrm{E}+00$ & $1.10 \mathrm{E}+01$ & 1.77E-02 & $1.00 \mathrm{E}+00$ & $2.64 \mathrm{E}-03$ & $2.40 \mathrm{E}-03$ & $1.50 \mathrm{E}-01$ & $1.10 \mathrm{E}-01$ & $2.10 \mathrm{E}+01$ & $6.49 \mathrm{E}-02$ \\
\hline 2016-10-02 & $6.25 \mathrm{E}-01$ & $9.00 \mathrm{E}+00$ & $9.40 \mathrm{E}+00$ & $1.87 \mathrm{E}-02$ & $1.26 \mathrm{E}+00$ & $4.33 \mathrm{E}-03$ & $2.02 \mathrm{E}-03$ & 1.10E-01 & $1.30 \mathrm{E}-01$ & $2.70 \mathrm{E}+01$ & $7.50 \mathrm{E}-02$ \\
\hline 2016-10-08 & & & & & & & & & & & \\
\hline 2016-10-20 & & & & & & & & & & & \\
\hline 2016-10-21 & & & & & & & & & & & \\
\hline 2016-10-22 & & & & & & & & & & & \\
\hline $2016-10-27$ & 3.59E-01 & $3.10 \mathrm{E}+01$ & $1.49 \mathrm{E}+01$ & $3.04 \mathrm{E}-02$ & $2.43 \mathrm{E}+00$ & $3.65 \mathrm{E}-03$ & $2.80 \mathrm{E}-03$ & $2.75 \mathrm{E}-01$ & $6.78 \mathrm{E}-01$ & $2.80 \mathrm{E}+01$ & 1.07E-01 \\
\hline 2016-11-02 & $8.53 \mathrm{E}-01$ & $6.30 \mathrm{E}+01$ & $2.59 \mathrm{E}+01$ & $3.02 \mathrm{E}-02$ & $2.43 \mathrm{E}+00$ & $5.84 \mathrm{E}-03$ & $3.83 \mathrm{E}-03$ & $2.75 \mathrm{E}-01$ & 6.07E-01 & $5.80 \mathrm{E}+01$ & $1.06 \mathrm{E}-01$ \\
\hline 2016-11-03 & & & & & & & & & & & \\
\hline 2016-11-08 & & & & & & & & & & & \\
\hline 2016-11-19 & $5.30 \mathrm{E}-01$ & $1.80 \mathrm{E}+02$ & $1.10 \mathrm{E}+00$ & $3.24 \mathrm{E}-02$ & $2.12 \mathrm{E}+00$ & $3.98 \mathrm{E}-03$ & 3.57E-03 & $5.50 \mathrm{E}-02$ & $8.24 \mathrm{E}-01$ & $3.20 \mathrm{E}+01$ & $1.01 \mathrm{E}-01$ \\
\hline 2016-11-23 & & & & & & & & & & & \\
\hline 2016-11-24 & & & & & & & & & & & \\
\hline 2016-11-26 & & & & & & & & & & & \\
\hline $2016-11-28$ & $1.06 \mathrm{E}+00$ & $9.30 \mathrm{E}+01$ & $5.31 \mathrm{E}+02$ & $3.03 \mathrm{E}-02$ & $2.44 \mathrm{E}+00$ & $8.42 \mathrm{E}-03$ & $4.38 \mathrm{E}-03$ & $1.00 \mathrm{E}-02$ & $6.62 \mathrm{E}-01$ & $5.40 \mathrm{E}+01$ & $1.25 \mathrm{E}-01$ \\
\hline 2016-11-30 & $8.33 \mathrm{E}-02$ & $6.80 \mathrm{E}+01$ & $2.28 \mathrm{E}+02$ & $1.05 \mathrm{E}-02$ & $2.26 \mathrm{E}-01$ & $5.32 \mathrm{E}-04$ & 1.15E-03 & $1.00 \mathrm{E}-02$ & 8.07E-02 & $2.00 \mathrm{E}+00$ & $2.50 \mathrm{E}-02$ \\
\hline 2016-12-06 & & & & & & & & & & & \\
\hline & & & & & & & & & & & \\
\hline Sample Count & 29 & 28 & 29 & 29 & 29 & 29 & 29 & 29 & 29 & 30 & 29 \\
\hline
\end{tabular}




\begin{tabular}{|c|c|c|c|c|c|c|c|c|c|c|c|}
\hline \multirow{2}{*}{ Events } & \multicolumn{11}{|c|}{ Effluent Concentration } \\
\hline & Al(mg/L) & $B O D(\mathrm{mg} / \mathrm{L})$ & $\mathrm{Cl}(\mathrm{mg} / \mathrm{L})$ & $\mathrm{Cu}(\mathrm{mg} / \mathrm{L})$ & $\mathrm{Fe}(\mathrm{mg} / \mathrm{L})$ & $\mathrm{Pb}(\mathrm{mg} / \mathrm{L})$ & $\mathrm{Ni}(\mathrm{mg} / \mathrm{L})$ & Nitrate(mg/L) & $\mathrm{TP}(\mathrm{mg} / \mathrm{L})$ & $\mathrm{TSS}(\mathrm{mg} / \mathrm{L})$ & $\mathrm{Zn}(\mathrm{mg} / \mathrm{L})$ \\
\hline \multicolumn{12}{|l|}{ 2016-01-08 } \\
\hline 2016-01-09 & $1.12 \mathrm{E}-01$ & $2.00 \mathrm{E}+00$ & $7.71 E+02$ & $1.13 \mathrm{E}-02$ & $2.46 \mathrm{E}-01$ & $5.94 \mathrm{E}-04$ & 5.00E-04 & $9.50 \mathrm{E}-01$ & 4.46E-02 & $2.00 \mathrm{E}+00$ & \\
\hline 2016-01-10 & $2.96 \mathrm{E}-01$ & $2.00 E+00$ & $6.12 \mathrm{E}+02$ & $2.00 \mathrm{E}-02$ & $5.00 \mathrm{E}-01$ & $1.82 \mathrm{E}-03$ & $1.37 \mathrm{E}-03$ & $8.00 \mathrm{E}-01$ & $1.01 \mathrm{E}-01$ & $2.00 \mathrm{E}+00$ & $3.52 \mathrm{E}-02$ \\
\hline $2016-02-02$ & $2.24 \mathrm{E}-01$ & $2.00 \mathrm{E}+00$ & $1.83 \mathrm{E}+03$ & $9.54 \mathrm{E}-03$ & 3.23E-01 & $9.81 \mathrm{E}-04$ & 1.17E-03 & 5.30E-01 & $6.15 \mathrm{E}-02$ & $4.00 \mathrm{E}+00$ & $7.99 \mathrm{E}-02$ \\
\hline 2016-02-16 & 2.63E-01 & $5.00 \mathrm{E}+00$ & $4.69 \mathrm{E}+03$ & $2.40 \mathrm{E}-02$ & $5.28 \mathrm{E}-01$ & 1.27E-03 & $2.72 \mathrm{E}-03$ & $3.50 \mathrm{E}-01$ & $8.88 \mathrm{E}-02$ & $7.00 \mathrm{E}+00$ & $1.64 \mathrm{E}-01$ \\
\hline \multicolumn{12}{|l|}{ 2016-02-19 } \\
\hline \multicolumn{12}{|l|}{$2016-02-24$} \\
\hline \multicolumn{12}{|l|}{ 2016-03-04 } \\
\hline 2016-03-10 & 4.75E-01 & $4.00 E+00$ & $3.58 \mathrm{E}+03$ & $2.28 \mathrm{E}-02$ & 4.56E-01 & $1.37 \mathrm{E}-03$ & $2.96 \mathrm{E}-03$ & $1.36 \mathrm{E}+00$ & $1.03 \mathrm{E}-01$ & $1.20 \mathrm{E}+01$ & $4.97 \mathrm{E}-02$ \\
\hline 2016-03-14 & 4.16E-01 & $2.00 \mathrm{E}+00$ & $8.62 \mathrm{E}+02$ & $3.10 \mathrm{E}-02$ & 7.11E-01 & $2.12 \mathrm{E}-03$ & $3.32 \mathrm{E}-03$ & $6.00 \mathrm{E}-01$ & $1.88 \mathrm{E}-01$ & $8.00 \mathrm{E}+00$ & $3.54 \mathrm{E}-02$ \\
\hline \multicolumn{12}{|l|}{ 2016-03-15 } \\
\hline \multicolumn{12}{|l|}{ 2016-03-16 } \\
\hline \multicolumn{12}{|l|}{ 2016-03-23 } \\
\hline 2016-03-31 & 3.57E-01 & $2.00 \mathrm{E}+00$ & $2.44 \mathrm{E}+02$ & $2.41 \mathrm{E}-02$ & 4.49E-01 & $1.38 \mathrm{E}-03$ & $2.75 \mathrm{E}-03$ & $5.50 \mathrm{E}-01$ & $2.58 \mathrm{E}-01$ & $3.00 \mathrm{E}+00$ & $2.50 \mathrm{E}-02$ \\
\hline 2016-04-04 & $2.69 \mathrm{E}-01$ & $4.00 \mathrm{E}+00$ & $1.63 \mathrm{E}+03$ & $2.69 \mathrm{E}-02$ & $3.92 \mathrm{E}-01$ & $1.01 \mathrm{E}-03$ & $3.15 \mathrm{E}-03$ & $5.50 \mathrm{E}-01$ & 1.34E-01 & $2.00 \mathrm{E}+00$ & $2.50 \mathrm{E}-02$ \\
\hline 2016-04-06 & $9.44 \mathrm{E}-02$ & $5.00 \mathrm{E}+00$ & $2.85 \mathrm{E}+03$ & $1.32 \mathrm{E}-02$ & $2.32 \mathrm{E}-01$ & $2.31 \mathrm{E}-04$ & 7.47E-04 & $6.20 \mathrm{E}-01$ & $5.22 \mathrm{E}-02$ & $2.00 \mathrm{E}+00$ & $2.50 \mathrm{E}-02$ \\
\hline \multicolumn{12}{|l|}{$2016-04-25$} \\
\hline 2016-05-26 & $6.81 \mathrm{E}-01$ & $1.00 \mathrm{E}+01$ & $7.93 E+01$ & $3.16 \mathrm{E}-02$ & 6.99E-01 & $1.89 \mathrm{E}-03$ & $3.49 \mathrm{E}-03$ & $1.26 \mathrm{E}+00$ & 2.14E-01 & $1.70 \mathrm{E}+01$ & $9.61 \mathrm{E}-02$ \\
\hline 2016-06-11 & 3.95E-02 & $3.00 \mathrm{E}+00$ & $2.49 \mathrm{E}+01$ & $7.53 \mathrm{E}-03$ & $5.83 \mathrm{E}-02$ & 1.43E-04 & $6.46 \mathrm{E}-04$ & $9.30 \mathrm{E}-01$ & 4.46E-02 & $2.00 \mathrm{E}+00$ & $2.50 \mathrm{E}-02$ \\
\hline \multicolumn{12}{|l|}{ 2016-06-26 } \\
\hline \multicolumn{12}{|l|}{ 2016-07-01 } \\
\hline \multicolumn{12}{|l|}{ 2016-07-07 } \\
\hline 2016-07-09 & 1.74E-01 & $6.00 \mathrm{E}+00$ & $3.38 \mathrm{E}+01$ & 1.35E-02 & $1.41 \mathrm{E}-01$ & $5.22 \mathrm{E}-04$ & $1.13 \mathrm{E}-03$ & $6.50 \mathrm{E}-01$ & $7.40 \mathrm{E}-02$ & $4.00 \mathrm{E}+00$ & $2.50 \mathrm{E}-02$ \\
\hline 2016-07-14 & 4.79E-02 & $6.00 \mathrm{E}+00$ & $2.16 \mathrm{E}+01$ & 1.06E-02 & $6.29 \mathrm{E}-02$ & $2.70 \mathrm{E}-04$ & $1.03 \mathrm{E}-03$ & $7.20 \mathrm{E}-01$ & 5.55E-02 & $2.00 \mathrm{E}+00$ & $2.50 \mathrm{E}-02$ \\
\hline $2016-07-14$ & $3.28 \mathrm{E}-02$ & $3.00 E+00$ & $1.93 \mathrm{E}+01$ & $6.34 \mathrm{E}-03$ & 4.09E-02 & $1.54 \mathrm{E}-04$ & 5.07E-04 & $3.50 \mathrm{E}-01$ & $4.14 \mathrm{E}-02$ & $2.00 E+00$ & $2.50 \mathrm{E}-02$ \\
\hline \multicolumn{12}{|l|}{$2016-07-25$} \\
\hline 2016-08-13 & $6.35 \mathrm{E}-02$ & & $1.11 \mathrm{E}+01$ & $1.34 \mathrm{E}-02$ & $1.29 \mathrm{E}-01$ & $3.84 \mathrm{E}-04$ & 1.07E-03 & $5.50 \mathrm{E}-01$ & $9.50 \mathrm{E}-02$ & $2.00 \mathrm{E}+00$ & $2.50 \mathrm{E}-02$ \\
\hline 2016-08-16 & $4.21 \mathrm{E}-02$ & $2.00 \mathrm{E}+00$ & $1.70 \mathrm{E}+01$ & 7.95E-03 & $5.97 \mathrm{E}-02$ & $1.70 \mathrm{E}-04$ & $6.19 \mathrm{E}-04$ & $2.75 \mathrm{E}-01$ & $4.98 \mathrm{E}-02$ & $2.00 \mathrm{E}+00$ & $2.50 \mathrm{E}-02$ \\
\hline $2016-08-20$ & & & & & & & & & & & \\
\hline $2016-08-21$ & & & & & & & & & & & \\
\hline $2016-08-25$ & & & & & & & & & & $3.00 \mathrm{E}+00$ & \\
\hline 2016-08-25 & & & & & & & & & & & \\
\hline 2016-09-07 & 2.14E-01 & $3.19 \mathrm{E}+00$ & $1.13 \mathrm{E}+01$ & $1.28 \mathrm{E}-02$ & 1.17E-01 & 3.39E-04 & $1.24 \mathrm{E}-03$ & 7.90E-01 & 9.19E-02 & $2.00 \mathrm{E}+00$ & $2.50 \mathrm{E}-02$ \\
\hline 2016-09-10 & & & & & & & & & & & \\
\hline 2016-09-17 & & & & & & & & & & & \\
\hline $2016-09-17$ & & & & & & & & & & & \\
\hline $2016-09-26$ & $8.15 \mathrm{E}-02$ & $6.00 E+00$ & $9.32 \mathrm{E}+00$ & $1.01 \mathrm{E}-02$ & $7.76 \mathrm{E}-02$ & $2.53 \mathrm{E}-04$ & $8.92 \mathrm{E}-04$ & $4.40 \mathrm{E}-01$ & $4.31 \mathrm{E}-02$ & $2.00 \mathrm{E}+00$ & $2.50 \mathrm{E}-02$ \\
\hline $2016-09-29$ & $6.68 \mathrm{E}-02$ & $2.00 E+00$ & $1.07 \mathrm{E}+01$ & 7.57E-03 & $1.09 \mathrm{E}-01$ & $2.18 \mathrm{E}-04$ & $1.09 \mathrm{E}-03$ & $3.00 \mathrm{E}-01$ & $4.81 \mathrm{E}-02$ & $2.00 \mathrm{E}+00$ & $2.50 \mathrm{E}-02$ \\
\hline $2016-10-02$ & $4.90 \mathrm{E}-02$ & $2.00 \mathrm{E}+00$ & $9.58 \mathrm{E}+00$ & $6.20 \mathrm{E}-03$ & $9.30 \mathrm{E}-02$ & 3.15E-04 & $5.74 \mathrm{E}-04$ & $1.70 \mathrm{E}-01$ & $3.15 \mathrm{E}-02$ & $2.00 \mathrm{E}+00$ & $2.50 \mathrm{E}-02$ \\
\hline $2016-10-08$ & & & & & & & & & & & \\
\hline $2016-10-20$ & & & & & & & & & & & \\
\hline $2016-10-21$ & & & & & & & & & & & \\
\hline $2016-10-22$ & & & & & & & & & & & \\
\hline $2016-10-27$ & $2.22 \mathrm{E}-01$ & $1.00 \mathrm{E}+01$ & $2.19 \mathrm{E}+01$ & $2.45 \mathrm{E}-02$ & 3.05E-01 & $6.21 \mathrm{E}-04$ & $1.27 \mathrm{E}-03$ & $2.75 \mathrm{E}-01$ & 1.03E-01 & $6.00 \mathrm{E}+00$ & $2.50 \mathrm{E}-02$ \\
\hline 2016-11-02 & $1.38 \mathrm{E}-01$ & $1.80 \mathrm{E}+01$ & $2.15 E+01$ & 1.44E-02 & $2.87 \mathrm{E}-01$ & $6.40 \mathrm{E}-04$ & $3.16 \mathrm{E}-03$ & $2.75 \mathrm{E}-01$ & $8.20 \mathrm{E}-02$ & $2.00 \mathrm{E}+00$ & $2.50 \mathrm{E}-02$ \\
\hline 2016-11-03 & & & & & & & & & & & \\
\hline 2016-11-08 & & & & & & & & & & & \\
\hline 2016-11-19 & 8.67E-02 & $4.98 \mathrm{E}+01$ & $1.10 \mathrm{E}+00$ & $1.51 \mathrm{E}-02$ & 1.43E-01 & 4.47E-04 & $1.24 \mathrm{E}-03$ & $1.70 \mathrm{E}-01$ & $6.26 \mathrm{E}-02$ & $4.00 \mathrm{E}+00$ & $2.50 \mathrm{E}-02$ \\
\hline $2016-11-23$ & & & & & & & & & & & \\
\hline 2016-11-24 & & & & & & & & & & & \\
\hline $2016-11-26$ & & & & & & & & & & & \\
\hline 2016-11-28 & $3.35 \mathrm{E}+00$ & $1.70 \mathrm{E}+01$ & $1.56 \mathrm{E}+02$ & $4.18 \mathrm{E}-02$ & $4.56 \mathrm{E}+00$ & 1.66E-02 & $5.81 \mathrm{E}-03$ & $1.00 \mathrm{E}-02$ & $9.08 \mathrm{E}-01$ & $1.50 \mathrm{E}+02$ & $2.18 \mathrm{E}-01$ \\
\hline 2016-11-30 & 5.54E-01 & $2.20 \mathrm{E}+01$ & $9.74 \mathrm{E}+01$ & 1.19E-02 & 7.46E-01 & $2.13 \mathrm{E}-03$ & $1.80 \mathrm{E}-03$ & $1.00 \mathrm{E}-02$ & $1.20 \mathrm{E}-01$ & $4.00 \mathrm{E}+00$ & $2.67 \mathrm{E}-02$ \\
\hline 2016-12-06 & & & & & & & & & & & \\
\hline & & & & & & & & & & & \\
\hline Sample Count & 25 & 24 & 25 & 25 & 25 & 25 & 25 & 25 & 25 & 26 & 24 \\
\hline
\end{tabular}




\begin{tabular}{|c|c|c|c|c|c|c|c|c|}
\hline \multirow[b]{2}{*}{ Events } & \multicolumn{8}{|c|}{ Influent+B1:I32 Concentration (Dissolved Only) } \\
\hline & $\mathrm{Al}(\mathrm{mg} / \mathrm{L})$ & $\mathrm{BOD}(\mathrm{mg} / \mathrm{L})$ & $\mathrm{Cu}(\mathrm{mg} / \mathrm{L})$ & $\mathrm{Fe}(\mathrm{mg} / \mathrm{L})$ & $\mathrm{Pb}(\mathrm{mg} / \mathrm{L})$ & $\mathrm{Ni}(\mathrm{mg} / \mathrm{L})$ & $\mathrm{TP}(\mathrm{mg} / \mathrm{L})$ & $\mathrm{Zn}(\mathrm{mg} / \mathrm{L})$ \\
\hline 2016-01-08 & $2.5 \mathrm{E}-02$ & $3.0 \mathrm{E}+00$ & $2.5 \mathrm{E}-03$ & $3.0 \mathrm{E}-01$ & $2.2 \mathrm{E}-04$ & $1.3 \mathrm{E}-03$ & $2.9 \mathrm{E}-02$ & $2.5 \mathrm{E}-02$ \\
\hline \multicolumn{9}{|l|}{ 2016-01-09 } \\
\hline 2016-01-10 & 4.7E-02 & $7.0 \mathrm{E}+00$ & $1.2 \mathrm{E}-02$ & $6.4 \mathrm{E}-02$ & 2.7E-04 & $1.6 \mathrm{E}-03$ & $2.2 \mathrm{E}-02$ & $3.6 \mathrm{E}-02$ \\
\hline $2016-02-02$ & $3.8 \mathrm{E}-02$ & $1.0 \mathrm{E}+01$ & $1.8 \mathrm{E}-02$ & $2.7 \mathrm{E}-01$ & $8.8 \mathrm{E}-04$ & $3.0 \mathrm{E}-03$ & $4.5 \mathrm{E}-02$ & $5.4 \mathrm{E}-02$ \\
\hline \multicolumn{9}{|l|}{ 2016-02-16 } \\
\hline 2016-02-19 & $2.5 \mathrm{E}-02$ & $2.4 \mathrm{E}+01$ & $2.8 \mathrm{E}-02$ & $1.2 \mathrm{E}+00$ & $1.5 \mathrm{E}-04$ & $1.1 \mathrm{E}-02$ & $4.4 \mathrm{E}-02$ & $1.1 \mathrm{E}-01$ \\
\hline \multicolumn{9}{|l|}{ 2016-02-24 } \\
\hline 2016-03-04 & $2.5 \mathrm{E}-02$ & $4.0 \mathrm{E}+00$ & $3.0 \mathrm{E}-02$ & $3.1 \mathrm{E}-01$ & $1.3 \mathrm{E}-04$ & $1.3 \mathrm{E}-02$ & $5.0 \mathrm{E}-02$ & $9.2 \mathrm{E}-02$ \\
\hline 2016-03-10 & $3.8 \mathrm{E}-02$ & $9.0 \mathrm{E}+00$ & $2.3 \mathrm{E}-02$ & $9.0 \mathrm{E}-02$ & $2.0 \mathrm{E}-04$ & $5.9 \mathrm{E}-03$ & $2.5 \mathrm{E}-02$ & $5.5 \mathrm{E}-02$ \\
\hline 2016-03-14 & $9.2 \mathrm{E}-02$ & $6.0 \mathrm{E}+00$ & $1.5 \mathrm{E}-02$ & $1.3 \mathrm{E}-01$ & 7.0E-04 & $2.1 \mathrm{E}-03$ & $3.9 \mathrm{E}-02$ & $2.8 \mathrm{E}-02$ \\
\hline 2016-03-15 & $6.0 \mathrm{E}-02$ & $7.0 \mathrm{E}+00$ & $9.6 \mathrm{E}-03$ & $4.3 \mathrm{E}-02$ & $2.5 \mathrm{E}-04$ & 9.7E-04 & $6.2 \mathrm{E}-02$ & $3.1 \mathrm{E}-02$ \\
\hline 2016-03-16 & $3.1 \mathrm{E}-02$ & $2.0 \mathrm{E}+00$ & $9.3 \mathrm{E}-03$ & $2.5 \mathrm{E}-02$ & $1.4 \mathrm{E}-04$ & $1.1 \mathrm{E}-03$ & $2.5 \mathrm{E}-02$ & $2.5 \mathrm{E}-02$ \\
\hline 2016-03-23 & 1.7E-01 & $2.0 \mathrm{E}+00$ & $3.4 \mathrm{E}-02$ & $3.1 \mathrm{E}-01$ & 7.5E-04 & $4.5 \mathrm{E}-03$ & 2.7E-01 & $2.9 \mathrm{E}-02$ \\
\hline 2016-03-31 & 3.7E-02 & $4.0 \mathrm{E}+00$ & 1.7E-02 & $5.8 \mathrm{E}-02$ & $2.6 \mathrm{E}-04$ & 1.7E-03 & 1.7E-02 & $3.5 \mathrm{E}-02$ \\
\hline \multicolumn{9}{|l|}{ 2016-04-04 } \\
\hline \multicolumn{9}{|l|}{ 2016-04-06 } \\
\hline 2016-04-25 & 8.5E-02 & $2.6 \mathrm{E}-02$ & & $2.0 \mathrm{E}-01$ & $4.5 \mathrm{E}-04$ & $3.8 \mathrm{E}-03$ & $1.1 \mathrm{E}-01$ & $2.6 \mathrm{E}-02$ \\
\hline 2016-05-26 & $6.9 \mathrm{E}-02$ & $3.5 \mathrm{E}+01$ & $2.4 \mathrm{E}-02$ & $9.0 \mathrm{E}-01$ & $1.6 \mathrm{E}-03$ & $6.9 \mathrm{E}-03$ & $2.2 \mathrm{E}-01$ & $6.8 \mathrm{E}-02$ \\
\hline 2016-06-11 & $3.0 \mathrm{E}-02$ & $8.0 \mathrm{E}+00$ & $1.3 \mathrm{E}-02$ & $1.0 \mathrm{E}-01$ & $4.2 \mathrm{E}-04$ & 2.7E-03 & $4.1 \mathrm{E}-02$ & $3.7 \mathrm{E}-02$ \\
\hline 2016-06-26 & 3.7E-01 & $5.2 \mathrm{E}+01$ & $4.3 \mathrm{E}-02$ & 8.3E-01 & $1.4 \mathrm{E}-03$ & $6.5 \mathrm{E}-03$ & 3.7E-01 & 1.2E-01 \\
\hline \multicolumn{9}{|l|}{ 2016-07-01 } \\
\hline \multicolumn{9}{|l|}{ 2016-07-07 } \\
\hline 2016-07-09 & $1.8 \mathrm{E}-01$ & $1.7 \mathrm{E}+01$ & $2.5 \mathrm{E}-02$ & $5.4 \mathrm{E}-01$ & $2.3 \mathrm{E}-03$ & $7.2 \mathrm{E}-03$ & $8.4 \mathrm{E}-02$ & $8.6 \mathrm{E}-02$ \\
\hline 2016-07-14 & $4.8 \mathrm{E}-02$ & $1.9 \mathrm{E}+01$ & $1.2 \mathrm{E}-02$ & 1.7E-01 & $5.8 \mathrm{E}-04$ & $4.2 \mathrm{E}-03$ & 9.7E-02 & $3.6 \mathrm{E}-02$ \\
\hline 2016-07-14 & $4.5 \mathrm{E}-02$ & $7.0 \mathrm{E}+00$ & $1.1 \mathrm{E}-02$ & $7.1 \mathrm{E}-02$ & $3.9 \mathrm{E}-04$ & $1.8 \mathrm{E}-03$ & $6.3 \mathrm{E}-02$ & $2.6 \mathrm{E}-02$ \\
\hline \multicolumn{9}{|l|}{ 2016-07-25 } \\
\hline 2016-08-13 & 4.6E-02 & & $1.3 \mathrm{E}-02$ & $1.6 \mathrm{E}-01$ & $5.8 \mathrm{E}-04$ & $1.9 \mathrm{E}-03$ & $1.0 \mathrm{E}-01$ & $3.6 \mathrm{E}-02$ \\
\hline 2016-08-16 & $5.0 \mathrm{E}-02$ & $1.0 \mathrm{E}+01$ & $1.3 \mathrm{E}-02$ & $2.4 \mathrm{E}-01$ & $7.2 \mathrm{E}-04$ & $2.4 \mathrm{E}-03$ & $6.6 \mathrm{E}-02$ & $4.2 \mathrm{E}-02$ \\
\hline \multicolumn{9}{|l|}{ 2016-08-20 } \\
\hline \multicolumn{9}{|l|}{ 2016-08-21 } \\
\hline 2016-08-25 & $3.5 \mathrm{E}-02$ & & $1.0 \mathrm{E}-02$ & 4.1E-01 & $6.4 \mathrm{E}-04$ & $2.8 \mathrm{E}-03$ & $4.4 \mathrm{E}-02$ & $3.8 \mathrm{E}-02$ \\
\hline \multicolumn{9}{|l|}{ 2016-08-25 } \\
\hline 2016-09-07 & $5.1 \mathrm{E}-02$ & $2.0 \mathrm{E}+01$ & $1.6 \mathrm{E}-02$ & $2.2 \mathrm{E}-01$ & $1.2 \mathrm{E}-03$ & $4.0 \mathrm{E}-03$ & $2.6 \mathrm{E}-01$ & $5.1 \mathrm{E}-02$ \\
\hline \multicolumn{9}{|l|}{ 2016-09-10 } \\
\hline \multicolumn{9}{|l|}{ 2016-09-17 } \\
\hline \multicolumn{9}{|l|}{ 2016-09-17 } \\
\hline 2016-09-26 & $4.9 \mathrm{E}-02$ & $1.3 \mathrm{E}+01$ & $1.1 \mathrm{E}-02$ & $2.2 \mathrm{E}-01$ & $9.1 \mathrm{E}-04$ & $3.5 \mathrm{E}-03$ & $1.2 \mathrm{E}-01$ & $3.1 \mathrm{E}-02$ \\
\hline 2016-09-29 & $4.5 \mathrm{E}-02$ & $3.0 \mathrm{E}+00$ & $1.1 \mathrm{E}-02$ & $3.6 \mathrm{E}-01$ & 7.4E-04 & $3.1 \mathrm{E}-03$ & $4.9 \mathrm{E}-02$ & 4.1E-02 \\
\hline 2016-09-29 & 7.7E-02 & $4.0 \mathrm{E}+00$ & $1.4 \mathrm{E}-02$ & $1.5 \mathrm{E}-01$ & 7.5E-04 & $1.6 \mathrm{E}-03$ & $3.8 \mathrm{E}-02$ & $4.1 \mathrm{E}-02$ \\
\hline 2016-10-02 & $5.2 \mathrm{E}-02$ & $8.0 \mathrm{E}+00$ & 9.7E-03 & $2.4 \mathrm{E}-01$ & $6.5 \mathrm{E}-04$ & $3.9 \mathrm{E}-03$ & $4.9 \mathrm{E}-02$ & 2.7E-02 \\
\hline \multicolumn{9}{|l|}{ 2016-10-08 } \\
\hline 2016-10-20 & & & & & & & & \\
\hline 2016-10-21 & & & & & & & & \\
\hline 2016-10-22 & & & & & & & & \\
\hline 2016-10-27 & $8.8 \mathrm{E}-02$ & $6.1 \mathrm{E}+01$ & $2.0 \mathrm{E}-02$ & $1.7 \mathrm{E}+00$ & $1.8 \mathrm{E}-03$ & $3.1 \mathrm{E}-03$ & $1.9 \mathrm{E}-01$ & $6.6 \mathrm{E}-02$ \\
\hline 2016-11-02 & $9.5 \mathrm{E}-02$ & $1.4 \mathrm{E}+01$ & $1.5 \mathrm{E}-02$ & $1.1 \mathrm{E}+00$ & 1.7E-03 & $2.9 \mathrm{E}-03$ & 2.7E-01 & $4.2 \mathrm{E}-02$ \\
\hline 2016-11-03 & & & & & & & & \\
\hline 2016-11-08 & & & & & & & & \\
\hline 2016-11-19 & $8.9 \mathrm{E}-02$ & $9.8 \mathrm{E}+01$ & $2.0 \mathrm{E}-02$ & $1.3 \mathrm{E}+00$ & $1.6 \mathrm{E}-03$ & $3.2 \mathrm{E}-03$ & $6.8 \mathrm{E}-01$ & $6.2 \mathrm{E}-02$ \\
\hline 2016-11-23 & & & & & & & & \\
\hline 2016-11-24 & & & & & & & & \\
\hline 2016-11-26 & & & & & & & & \\
\hline 2016-11-28 & 1.0E-01 & $9.0 \mathrm{E}+01$ & $1.1 \mathrm{E}-02$ & $1.0 \mathrm{E}+00$ & 2.1E-03 & $5.6 \mathrm{E}-03$ & $2.4 \mathrm{E}-01$ & $3.5 \mathrm{E}-02$ \\
\hline 2016-11-30 & 5.5E-01 & $2.2 \mathrm{E}+01$ & $1.2 \mathrm{E}-02$ & $7.5 \mathrm{E}-01$ & $2.1 \mathrm{E}-03$ & $1.8 \mathrm{E}-03$ & $1.2 \mathrm{E}-01$ & $2.7 \mathrm{E}-02$ \\
\hline
\end{tabular}




\begin{tabular}{|c|c|c|c|c|c|c|c|c|}
\hline & \multicolumn{8}{|c|}{ Effluent Concentration (Dissolved Only) } \\
\hline Events & $\mathrm{Al}(\mathrm{mg} / \mathrm{L})$ & $\mathrm{BOD}(\mathrm{mg} / \mathrm{L})$ & $\mathrm{Cu}(\mathrm{mg} / \mathrm{L})$ & $\mathrm{Fe}(\mathrm{mg} / \mathrm{L})$ & $\mathrm{Pb}(\mathrm{mg} / \mathrm{L})$ & $\mathrm{Ni}(\mathrm{mg} / \mathrm{L})$ & $\mathrm{TP}(\mathrm{mg} / \mathrm{L})$ & $\mathrm{Zn}(\mathrm{mg} / \mathrm{L})$ \\
\hline \multicolumn{9}{|c|}{\begin{tabular}{l|l}
$2016-01-08$ & \\
\end{tabular}} \\
\hline 2016-01-09 & $2.5 \mathrm{E}-02$ & $2.0 \mathrm{E}+00$ & $1.0 \mathrm{E}-02$ & $1.1 \mathrm{E}-01$ & $2.3 \mathrm{E}-04$ & $5.0 \mathrm{E}-04$ & $4.0 \mathrm{E}-02$ & 4.7E-02 \\
\hline 2016-01-10 & $6.1 \mathrm{E}-02$ & $2.0 \mathrm{E}+00$ & $1.8 \mathrm{E}-02$ & $1.5 \mathrm{E}-01$ & 4.5E-04 & $1.3 \mathrm{E}-03$ & $7.2 \mathrm{E}-02$ & $2.5 \mathrm{E}-02$ \\
\hline $2016-02-02$ & $2.5 \mathrm{E}-02$ & $2.0 \mathrm{E}+00$ & $8.0 \mathrm{E}-03$ & $8.7 \mathrm{E}-02$ & $2.2 \mathrm{E}-04$ & $9.6 \mathrm{E}-04$ & $4.1 \mathrm{E}-02$ & $6.2 \mathrm{E}-02$ \\
\hline 2016-02-16 & $3.0 \mathrm{E}-02$ & $4.0 \mathrm{E}+00$ & $1.7 \mathrm{E}-02$ & $3.5 \mathrm{E}-01$ & $2.4 \mathrm{E}-04$ & $2.1 \mathrm{E}-03$ & $5.5 \mathrm{E}-02$ & $1.3 \mathrm{E}-01$ \\
\hline \multicolumn{9}{|l|}{ 2016-02-19 } \\
\hline \multicolumn{9}{|l|}{ 2016-02-24 } \\
\hline \multicolumn{9}{|l|}{ 2016-03-04 } \\
\hline 2016-03-10 & $4.4 \mathrm{E}-02$ & $3.0 \mathrm{E}+00$ & $1.9 \mathrm{E}-02$ & $1.2 \mathrm{E}-01$ & 3.0E-04 & $2.8 \mathrm{E}-03$ & $6.4 \mathrm{E}-02$ & $3.2 \mathrm{E}-02$ \\
\hline 2016-03-14 & $9.8 \mathrm{E}-02$ & $2.0 \mathrm{E}+00$ & $2.8 \mathrm{E}-02$ & $2.2 \mathrm{E}-01$ & $5.5 \mathrm{E}-04$ & $2.8 \mathrm{E}-03$ & $1.6 \mathrm{E}-01$ & $2.5 \mathrm{E}-02$ \\
\hline \multicolumn{9}{|l|}{ 2016-03-15 } \\
\hline \multicolumn{9}{|l|}{ 2016-03-16 } \\
\hline \multicolumn{9}{|l|}{ 2016-03-23 } \\
\hline 2016-03-31 & 1.7E-01 & $2.0 \mathrm{E}+00$ & $2.4 \mathrm{E}-02$ & $2.4 \mathrm{E}-01$ & $6.6 \mathrm{E}-04$ & $2.4 \mathrm{E}-03$ & $2.4 \mathrm{E}-01$ & $2.5 \mathrm{E}-02$ \\
\hline 2016-04-04 & $1.1 \mathrm{E}-01$ & $1.7 \mathrm{E}+01$ & $2.6 \mathrm{E}-02$ & $2.5 \mathrm{E}-01$ & 3.7E-04 & $3.4 \mathrm{E}-03$ & $9.9 \mathrm{E}-02$ & $2.5 \mathrm{E}-02$ \\
\hline 2016-04-06 & $3.1 \mathrm{E}-02$ & $1.6 \mathrm{E}+01$ & $1.2 \mathrm{E}-02$ & $1.8 \mathrm{E}-01$ & $1.3 \mathrm{E}-04$ & $6.5 \mathrm{E}-04$ & $3.9 \mathrm{E}-02$ & $2.5 \mathrm{E}-02$ \\
\hline \multicolumn{9}{|l|}{ 2016-04-25 } \\
\hline 2016-05-26 & $4.3 \mathrm{E}-02$ & $9.0 \mathrm{E}+00$ & $2.2 \mathrm{E}-02$ & $7.2 \mathrm{E}-02$ & $2.6 \mathrm{E}-04$ & $3.1 \mathrm{E}-03$ & $7.1 \mathrm{E}-02$ & $6.3 \mathrm{E}-02$ \\
\hline 2016-06-11 & $2.6 \mathrm{E}-02$ & $2.0 \mathrm{E}+00$ & 7.9E-03 & 4.7E-02 & $1.4 \mathrm{E}-04$ & $1.2 \mathrm{E}-03$ & $3.4 \mathrm{E}-02$ & $2.5 \mathrm{E}-02$ \\
\hline \multicolumn{9}{|l|}{ 2016-06-26 } \\
\hline \multicolumn{9}{|l|}{ 2016-07-01 } \\
\hline \multicolumn{9}{|l|}{ 2016-07-07 } \\
\hline 2016-07-09 & $3.1 \mathrm{E}-02$ & $4.0 \mathrm{E}+00$ & $9.5 \mathrm{E}-03$ & $5.9 \mathrm{E}-02$ & $2.1 \mathrm{E}-04$ & $1.9 \mathrm{E}-03$ & $3.2 \mathrm{E}-02$ & $2.5 \mathrm{E}-02$ \\
\hline 2016-07-14 & $2.5 \mathrm{E}-02$ & $5.0 \mathrm{E}+00$ & $9.5 \mathrm{E}-03$ & 3.7E-02 & $1.5 \mathrm{E}-04$ & $7.9 \mathrm{E}-03$ & $3.1 \mathrm{E}-02$ & $2.5 \mathrm{E}-02$ \\
\hline 2016-07-14 & $2.5 \mathrm{E}-02$ & $2.0 \mathrm{E}+00$ & $6.5 \mathrm{E}-03$ & $2.5 \mathrm{E}-02$ & $1.3 \mathrm{E}-04$ & $1.1 \mathrm{E}-03$ & $2.5 \mathrm{E}-02$ & $2.5 \mathrm{E}-02$ \\
\hline \multicolumn{9}{|l|}{ 2016-07-25 } \\
\hline 2016-08-13 & $2.5 \mathrm{E}-02$ & & $1.2 \mathrm{E}-02$ & $7.9 \mathrm{E}-02$ & $2.0 \mathrm{E}-04$ & $2.6 \mathrm{E}-03$ & $5.3 \mathrm{E}-02$ & $2.5 \mathrm{E}-02$ \\
\hline 2016-08-16 & $2.5 \mathrm{E}-02$ & $2.7 \mathrm{E}+00$ & 7.3E-03 & $3.6 \mathrm{E}-02$ & $1.3 \mathrm{E}-04$ & $1.0 \mathrm{E}-03$ & $2.9 \mathrm{E}-02$ & $2.5 \mathrm{E}-02$ \\
\hline \multicolumn{9}{|l|}{ 2016-08-20 } \\
\hline \multicolumn{9}{|l|}{ 2016-08-21 } \\
\hline 2016-08-25 & $2.5 \mathrm{E}-02$ & & 8.1E-03 & $5.2 \mathrm{E}-02$ & $1.3 \mathrm{E}-04$ & $2.9 \mathrm{E}-03$ & $2.9 \mathrm{E}-03$ & $2.5 \mathrm{E}-02$ \\
\hline \multicolumn{9}{|l|}{ 2016-08-25 } \\
\hline 2016-09-07 & $3.1 \mathrm{E}-02$ & $3.0 \mathrm{E}+00$ & $1.2 \mathrm{E}-02$ & 7.3E-02 & 2.4E-04 & $1.8 \mathrm{E}-03$ & $1.2 \mathrm{E}-01$ & $2.5 \mathrm{E}-02$ \\
\hline \multicolumn{9}{|l|}{ 2016-09-10 } \\
\hline 2016-09-17 & & & & & & & & \\
\hline 2016-09-17 & & & & & & & & \\
\hline 2016-09-26 & $2.5 \mathrm{E}-02$ & $3.0 \mathrm{E}+00$ & $9.2 \mathrm{E}-03$ & $4.4 \mathrm{E}-02$ & $1.3 \mathrm{E}-04$ & 1.7E-03 & $4.5 \mathrm{E}-02$ & $2.5 \mathrm{E}-02$ \\
\hline 2016-09-29 & $2.5 \mathrm{E}-02$ & $2.0 \mathrm{E}+00$ & $7.8 \mathrm{E}-03$ & $7.2 \mathrm{E}-02$ & $1.3 \mathrm{E}-04$ & $9.5 \mathrm{E}-04$ & $4.1 \mathrm{E}-02$ & $2.5 \mathrm{E}-02$ \\
\hline 2016-09-29 & $2.5 \mathrm{E}-02$ & $2.0 \mathrm{E}+00$ & $6.0 \mathrm{E}-03$ & $5.4 \mathrm{E}-02$ & $1.3 \mathrm{E}-04$ & $1.6 \mathrm{E}-03$ & $4.5 \mathrm{E}-02$ & $2.5 \mathrm{E}-02$ \\
\hline 2016-10-02 & $2.5 \mathrm{E}-02$ & $2.0 \mathrm{E}+00$ & 6.7E-03 & $6.2 \mathrm{E}-02$ & $1.5 \mathrm{E}-04$ & $1.6 \mathrm{E}-03$ & $4.1 \mathrm{E}-02$ & $2.5 \mathrm{E}-02$ \\
\hline 2016-10-08 & & & & & & & & \\
\hline 2016-10-20 & & & & & & & & \\
\hline 2016-10-21 & & & & & & & & \\
\hline 2016-10-22 & & & & & & & & \\
\hline 2016-10-27 & $3.9 \mathrm{E}-02$ & $1.4 \mathrm{E}+01$ & $2.3 \mathrm{E}-02$ & $2.0 \mathrm{E}-01$ & $3.4 \mathrm{E}-04$ & $1.3 \mathrm{E}-03$ & $7.9 \mathrm{E}-02$ & $2.5 \mathrm{E}-02$ \\
\hline 2016-11-02 & $2.6 \mathrm{E}-02$ & $1.7 \mathrm{E}+01$ & $1.2 \mathrm{E}-02$ & 1.4E-01 & $3.3 \mathrm{E}-04$ & $2.7 \mathrm{E}-03$ & $9.7 \mathrm{E}-02$ & $2.5 \mathrm{E}-02$ \\
\hline 2016-11-03 & & & & & & & & \\
\hline 2016-11-08 & & & & & & & & \\
\hline 2016-11-19 & $2.5 \mathrm{E}-02$ & $5.0 \mathrm{E}+01$ & $1.4 \mathrm{E}-02$ & $8.4 \mathrm{E}-02$ & 2.9E-04 & $1.3 \mathrm{E}-03$ & $5.5 \mathrm{E}-02$ & $2.5 \mathrm{E}-02$ \\
\hline 2016-11-23 & & & & & & & & \\
\hline 2016-11-24 & & & & & & & & \\
\hline 2016-11-26 & & & & & & & & \\
\hline 2016-11-28 & $1.5 \mathrm{E}-01$ & $1.8 \mathrm{E}+01$ & $1.0 \mathrm{E}-02$ & $4.5 \mathrm{E}-01$ & $2.2 \mathrm{E}-03$ & $2.8 \mathrm{E}-03$ & $1.8 \mathrm{E}-01$ & $5.6 \mathrm{E}-02$ \\
\hline 2016-11-30 & 4.0E-02 & $2.0 \mathrm{E}+01$ & $9.0 \mathrm{E}-03$ & $1.2 \mathrm{E}-01$ & $3.6 \mathrm{E}-04$ & $1.3 \mathrm{E}-03$ & $2.4 \mathrm{E}-02$ & $2.5 \mathrm{E}-02$ \\
\hline
\end{tabular}


Appendix VI

\section{Inflow - Outflow Hydrograph and}

Sampling Details 


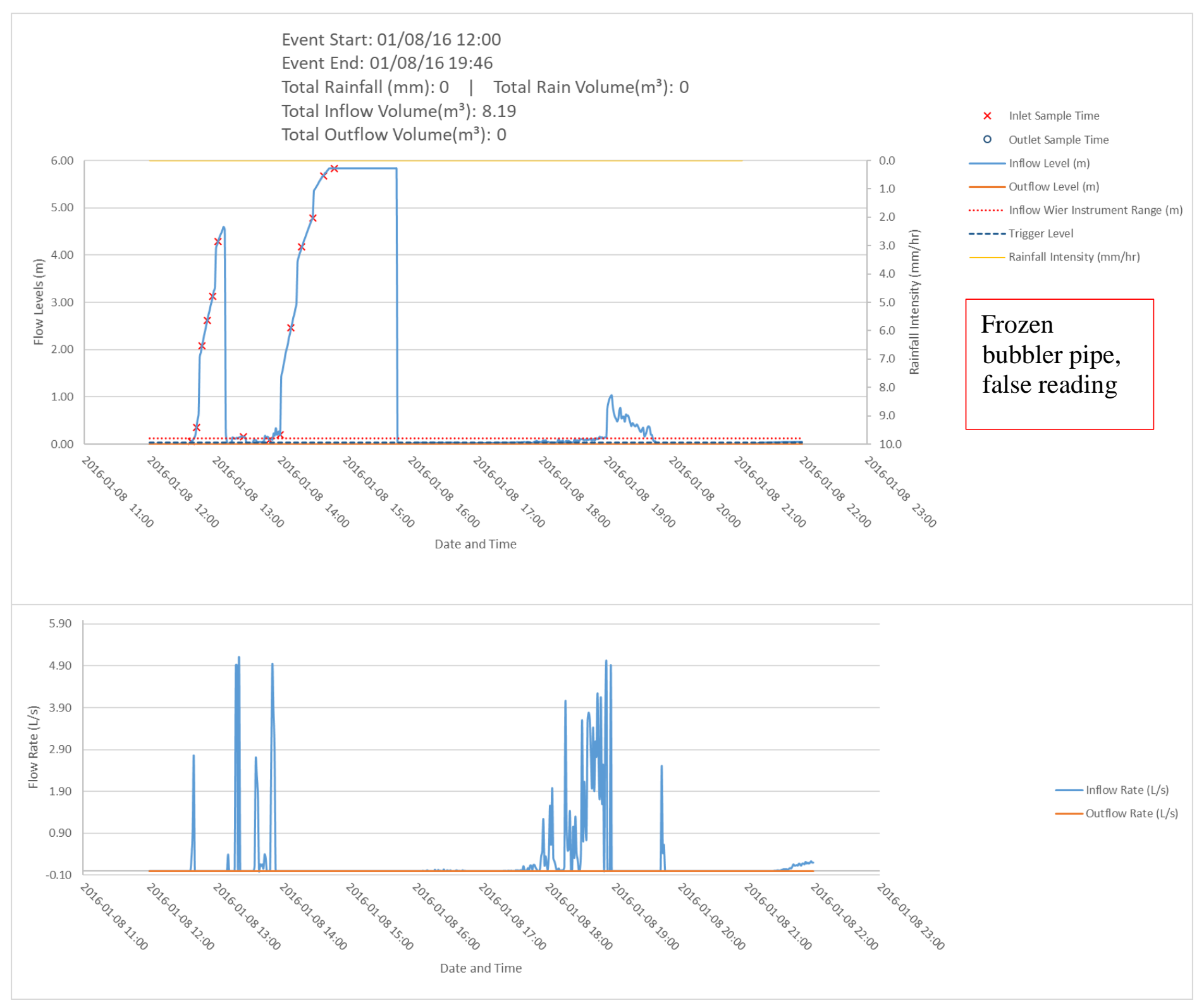




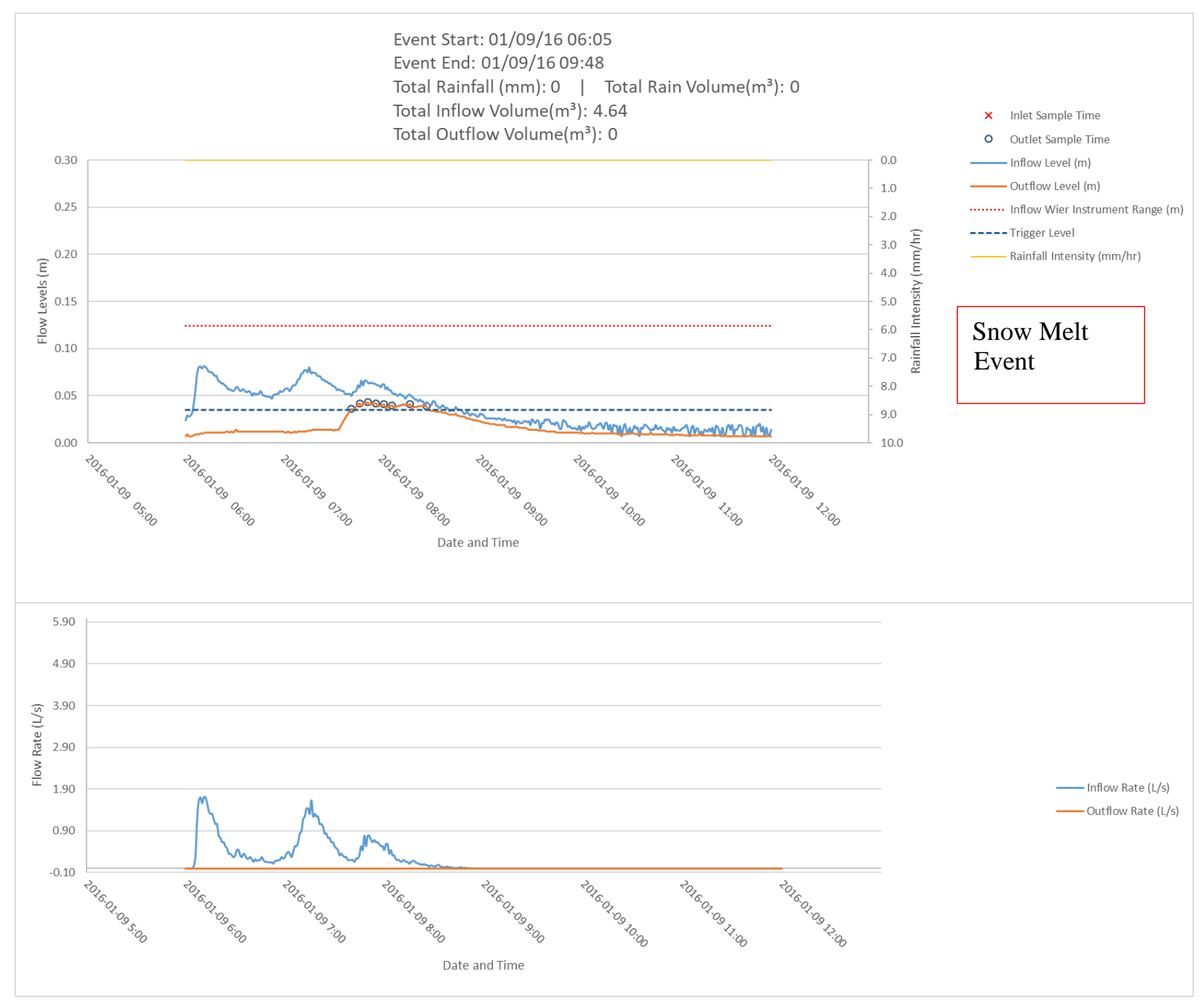




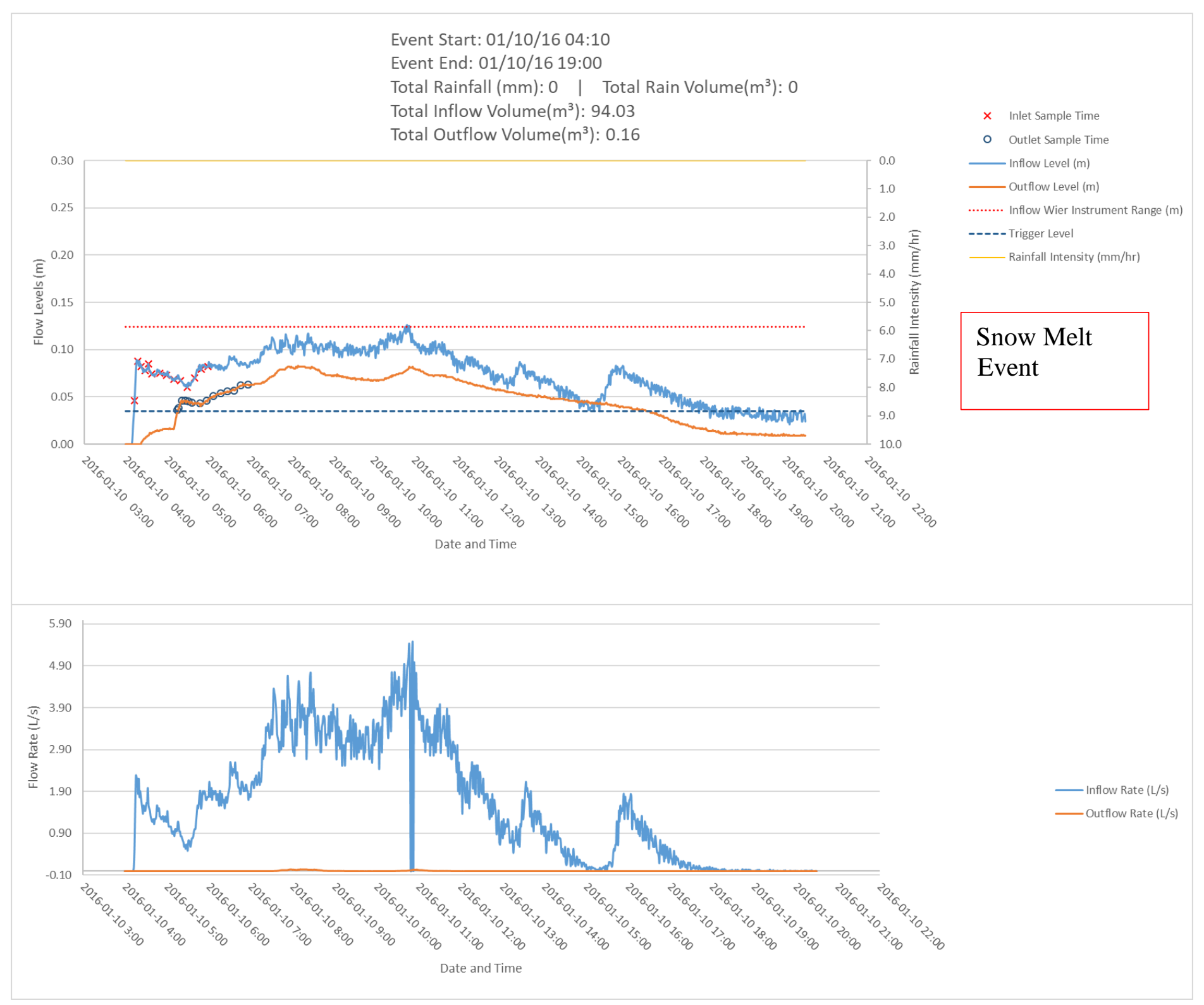




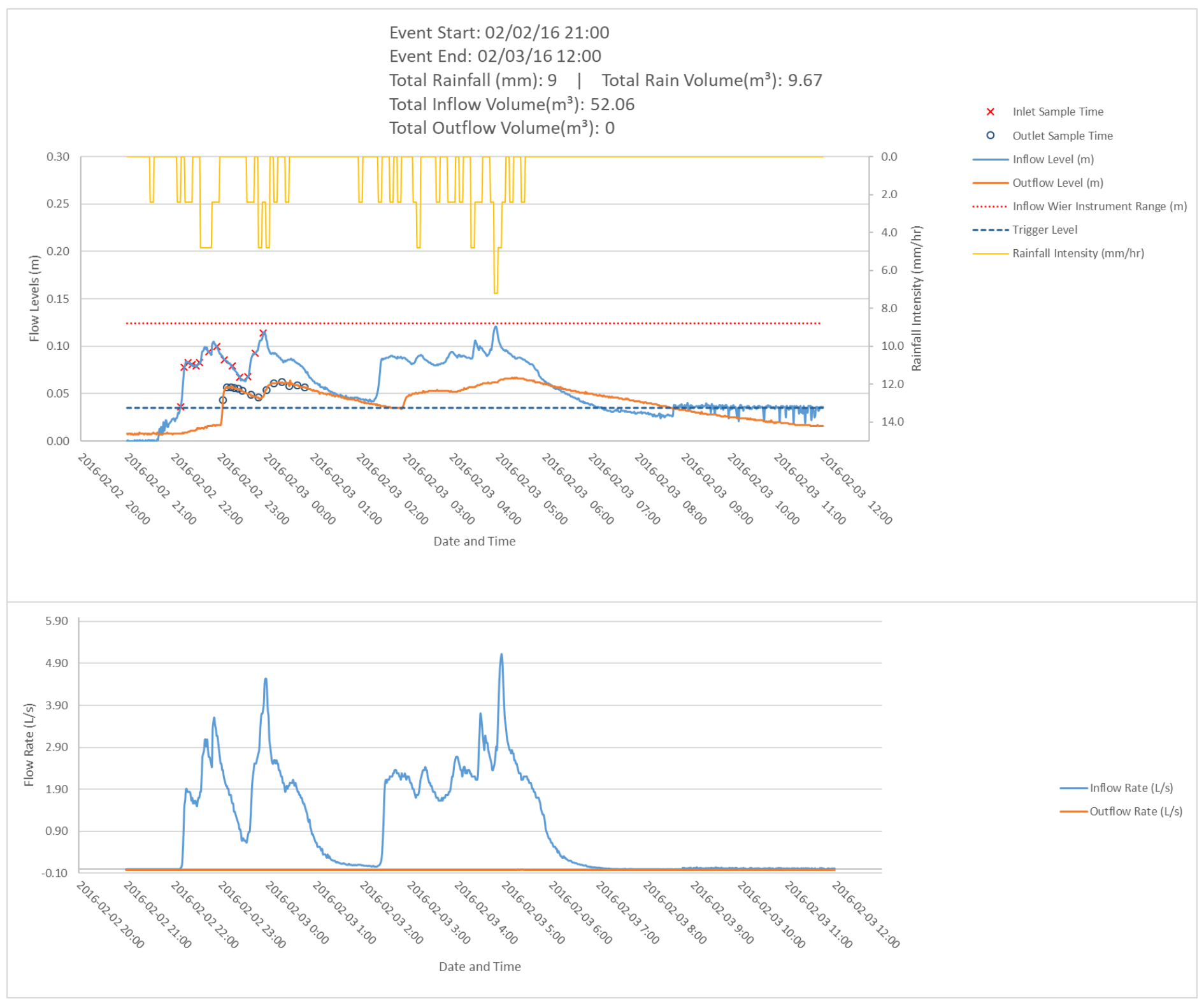

135 


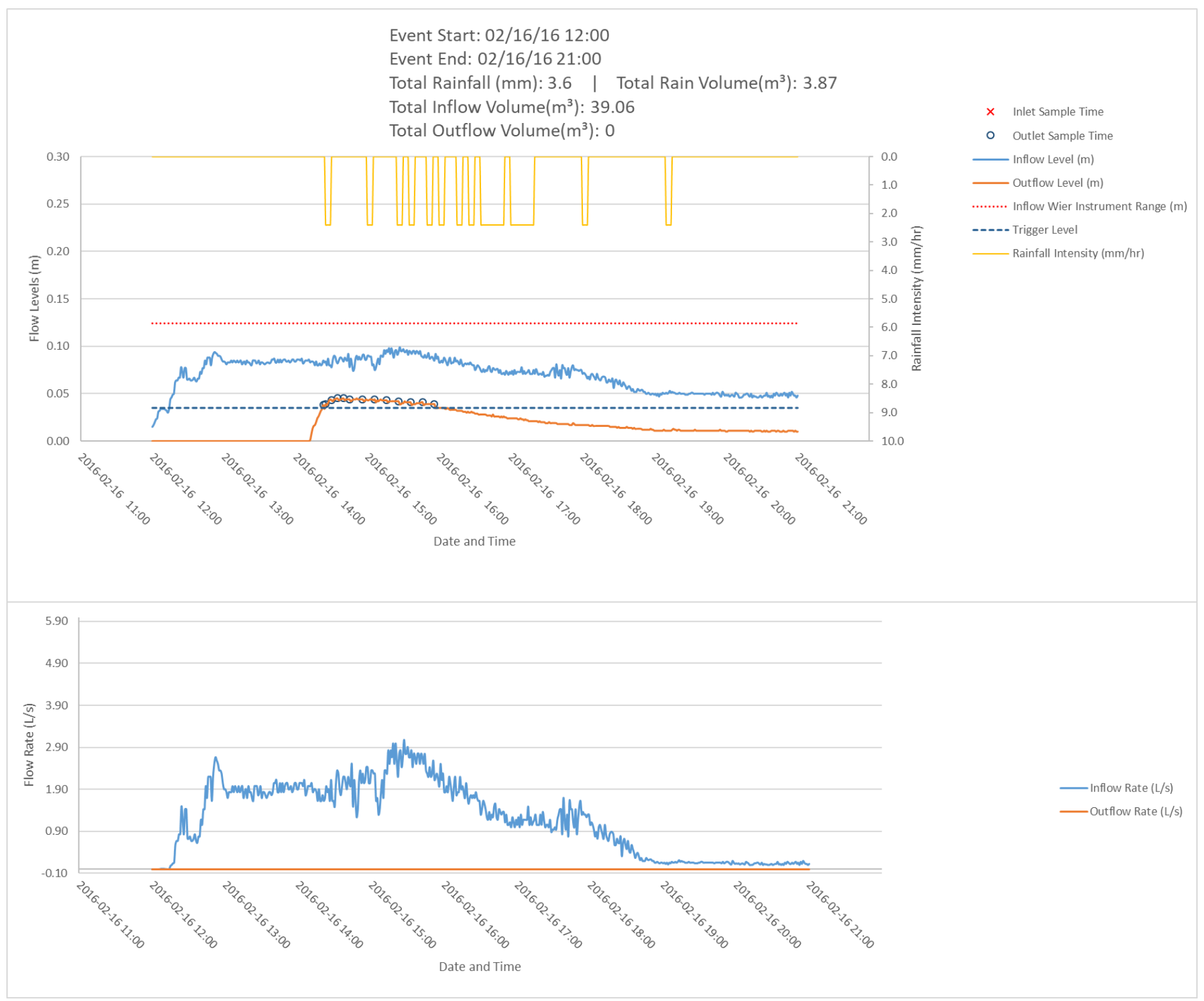

136 


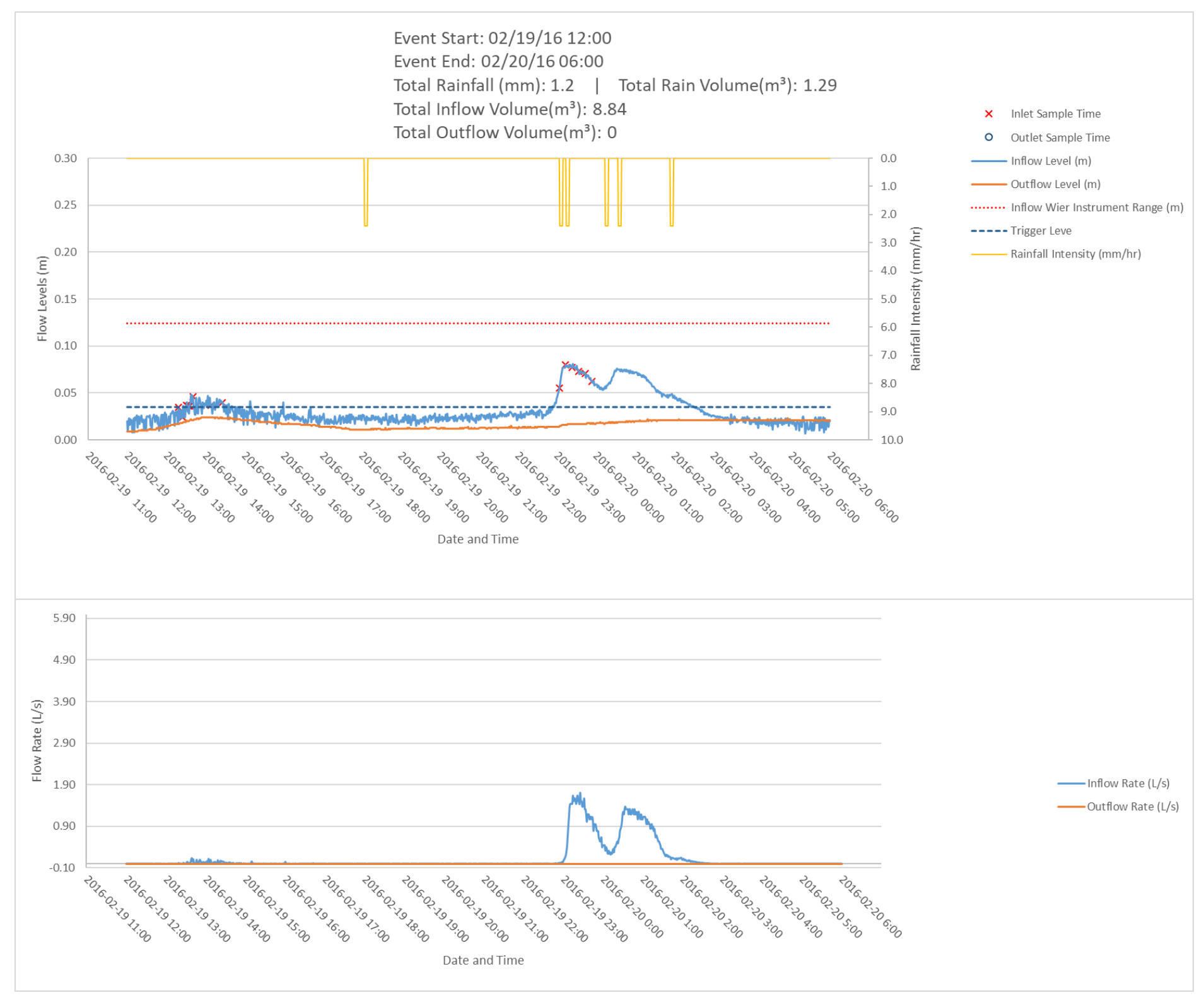




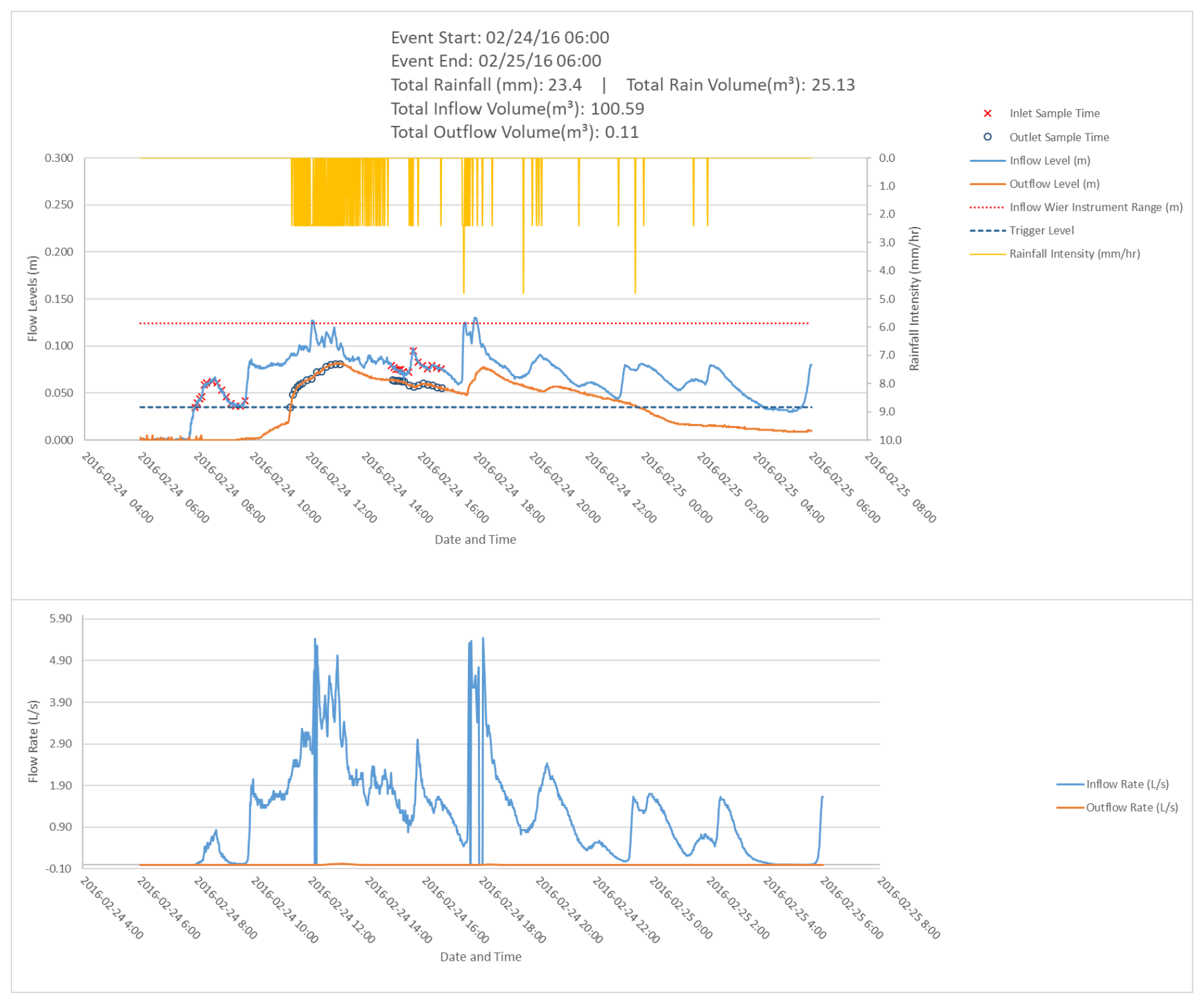




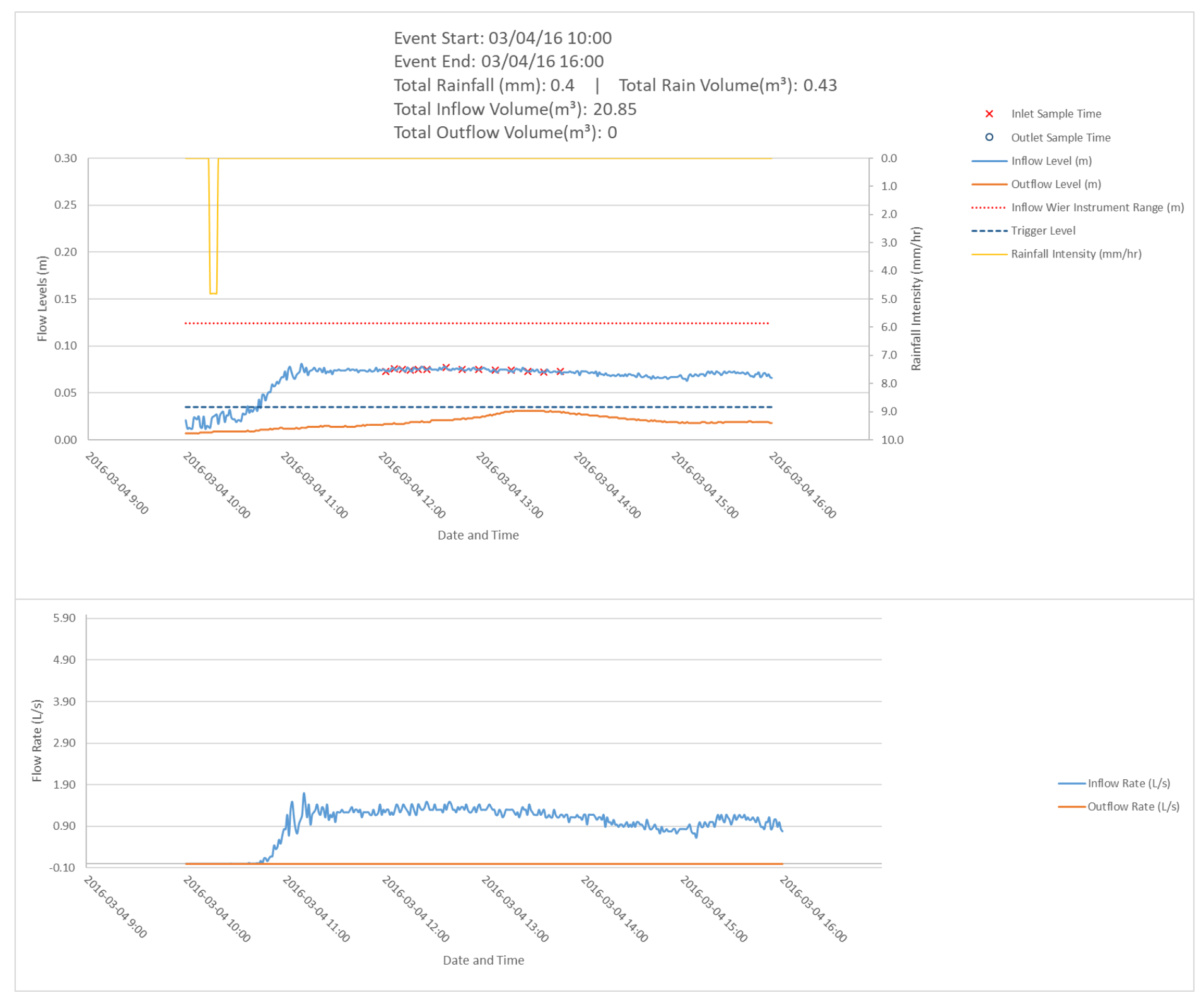




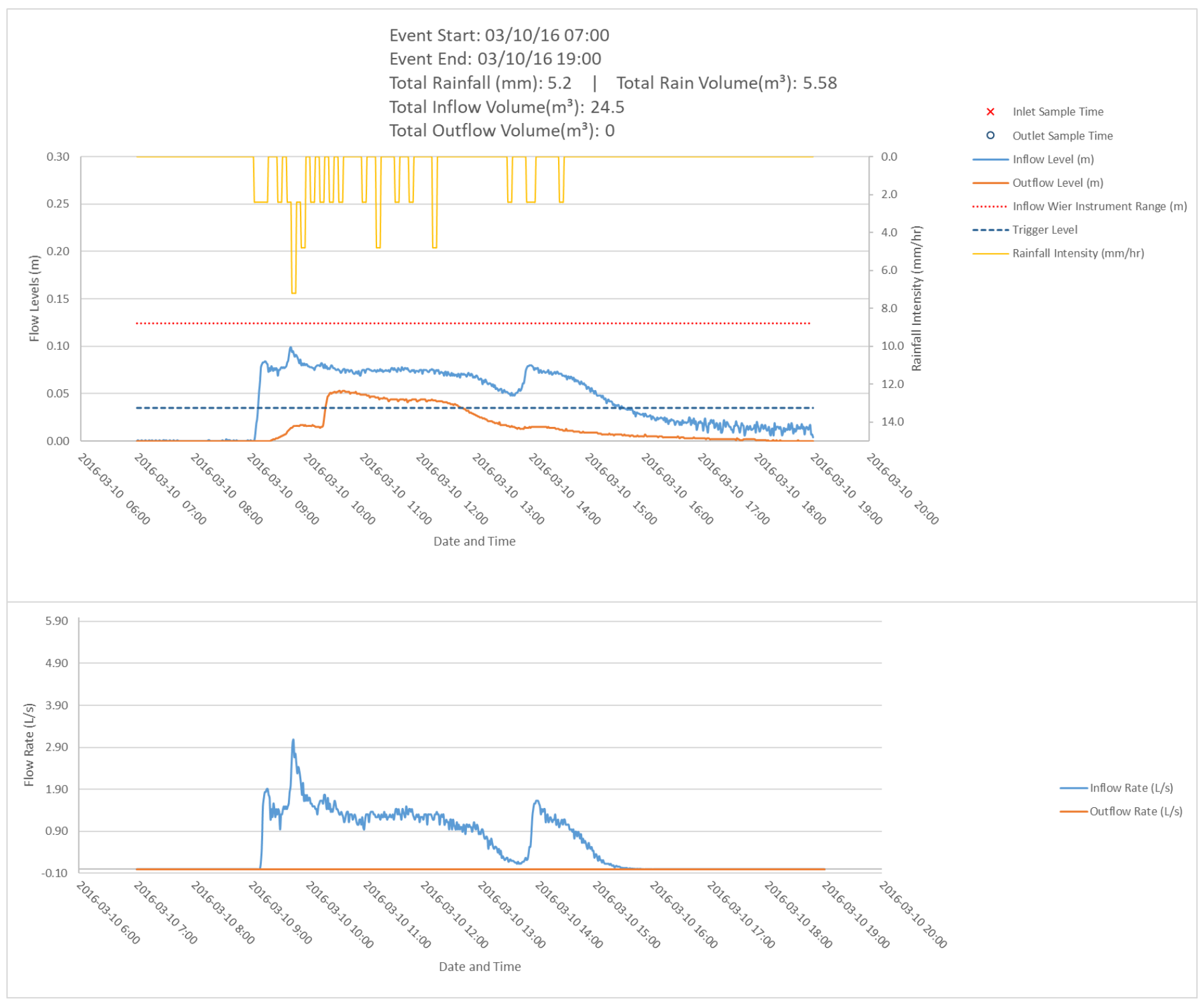

140 


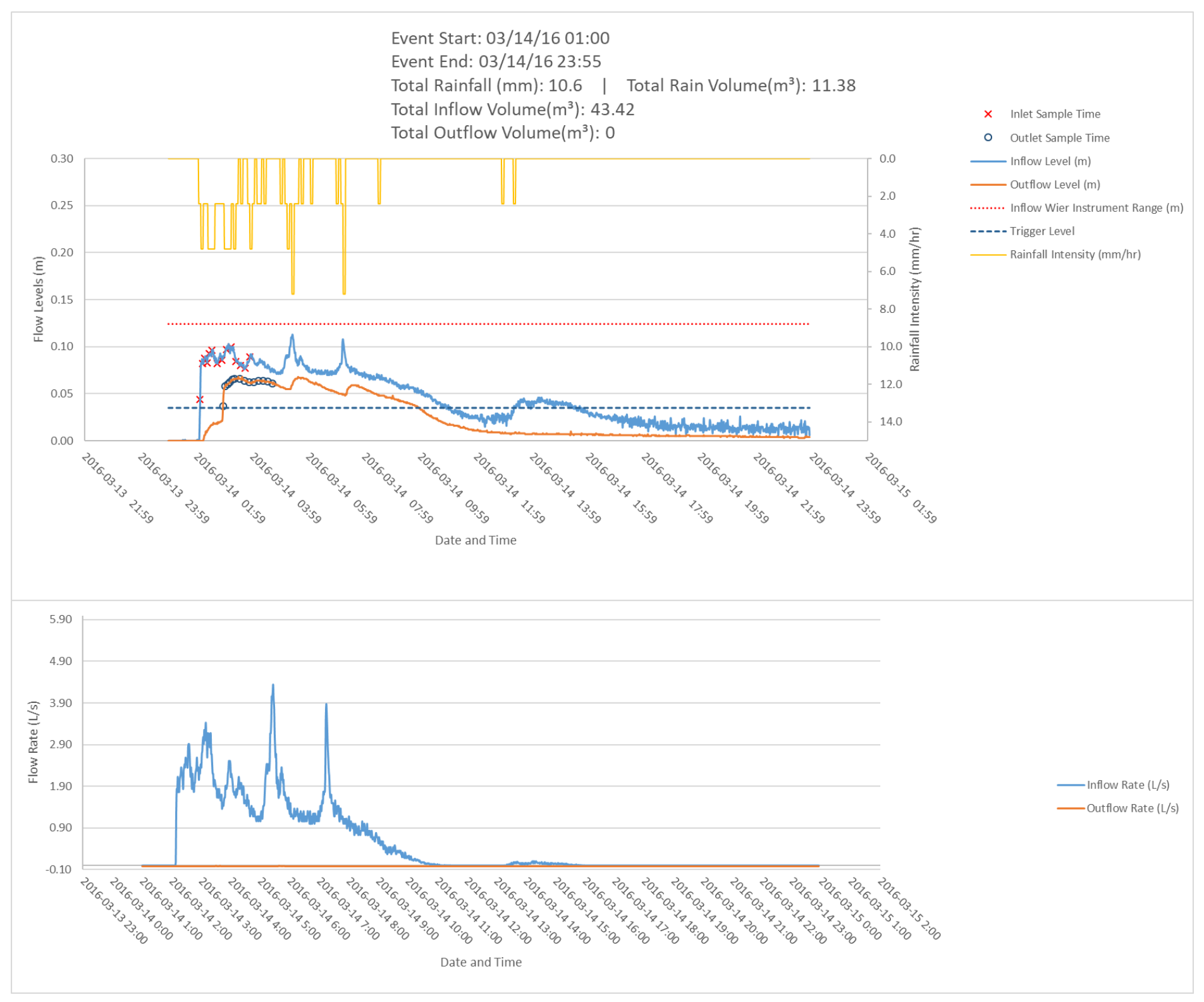




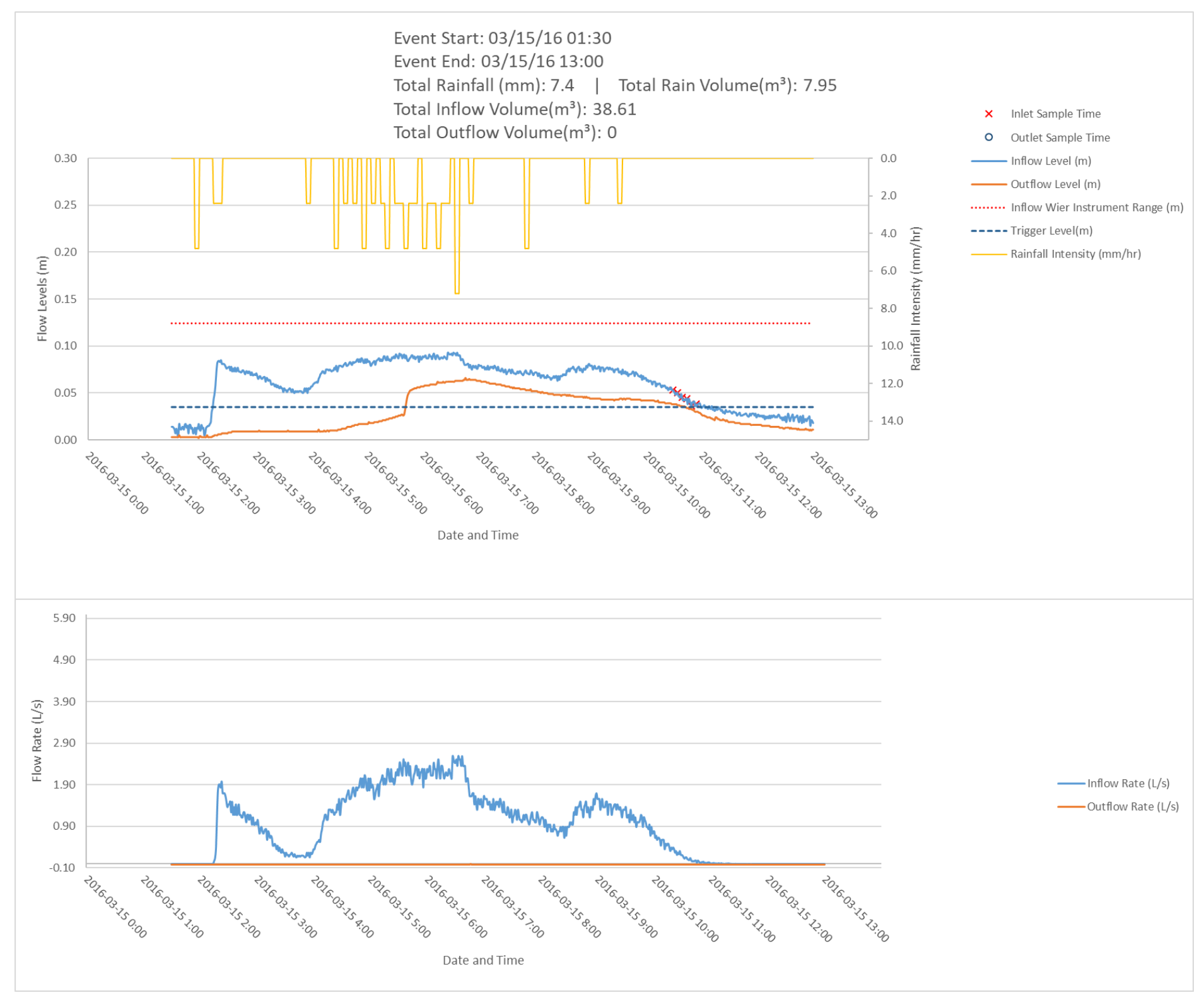




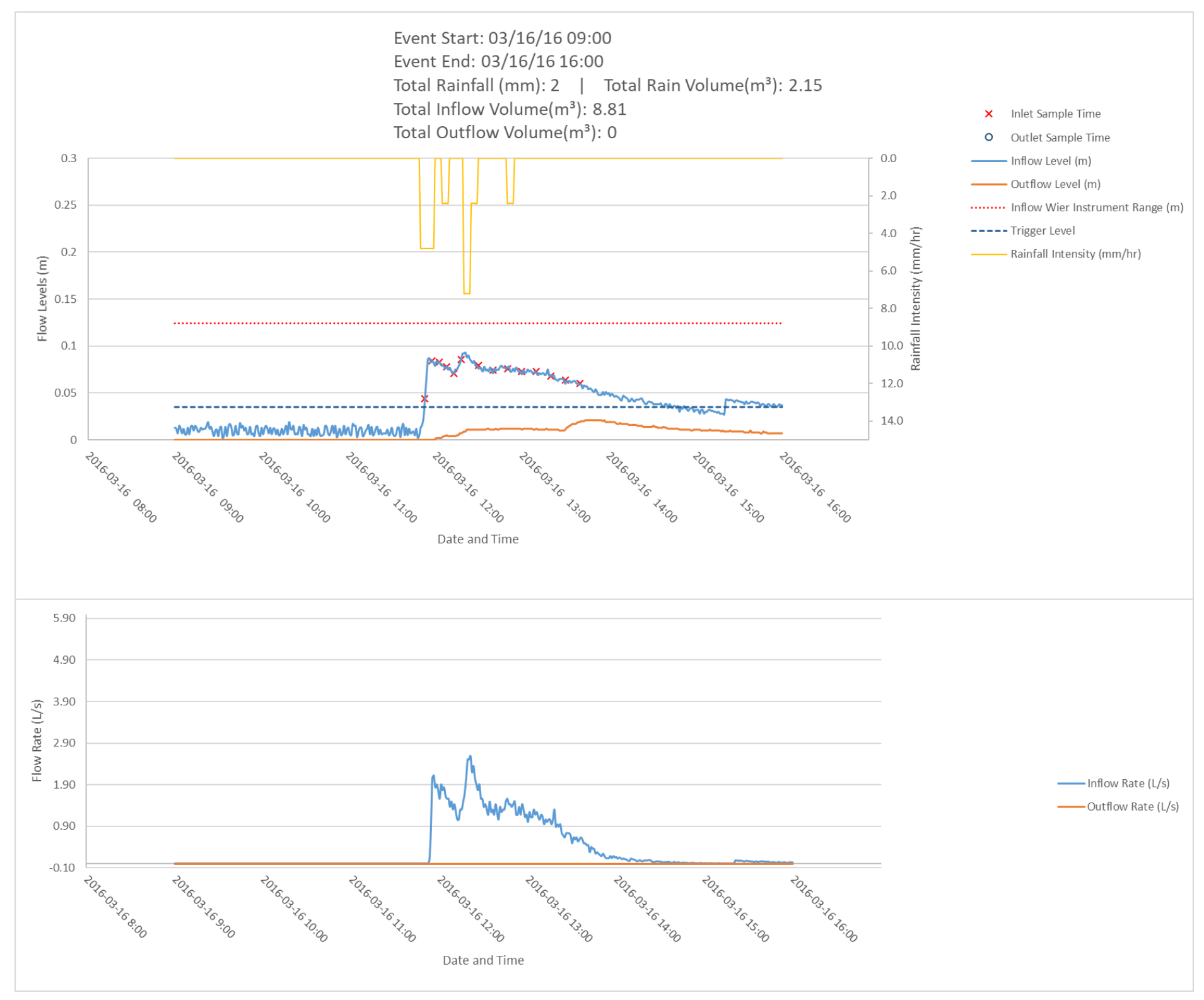




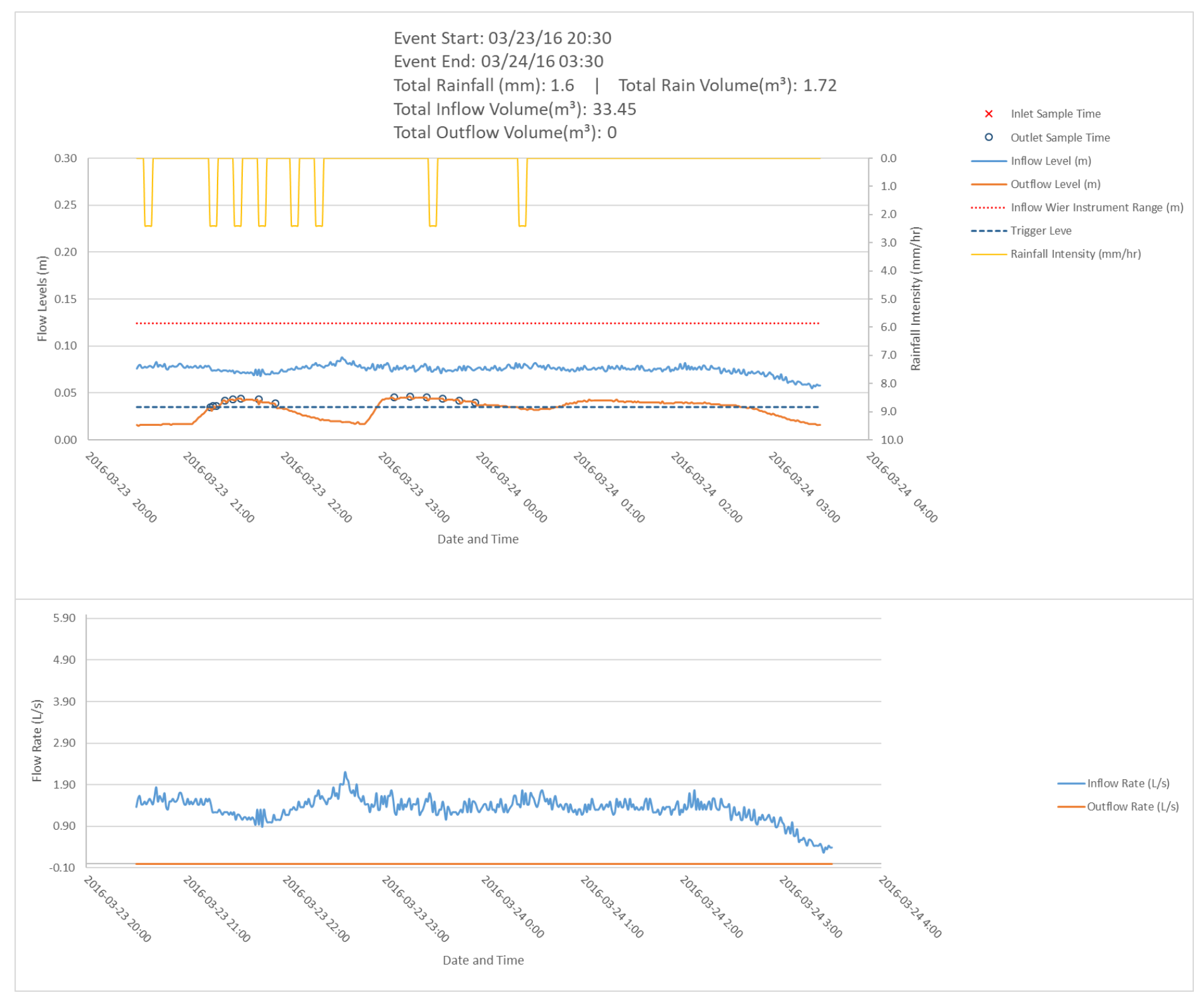




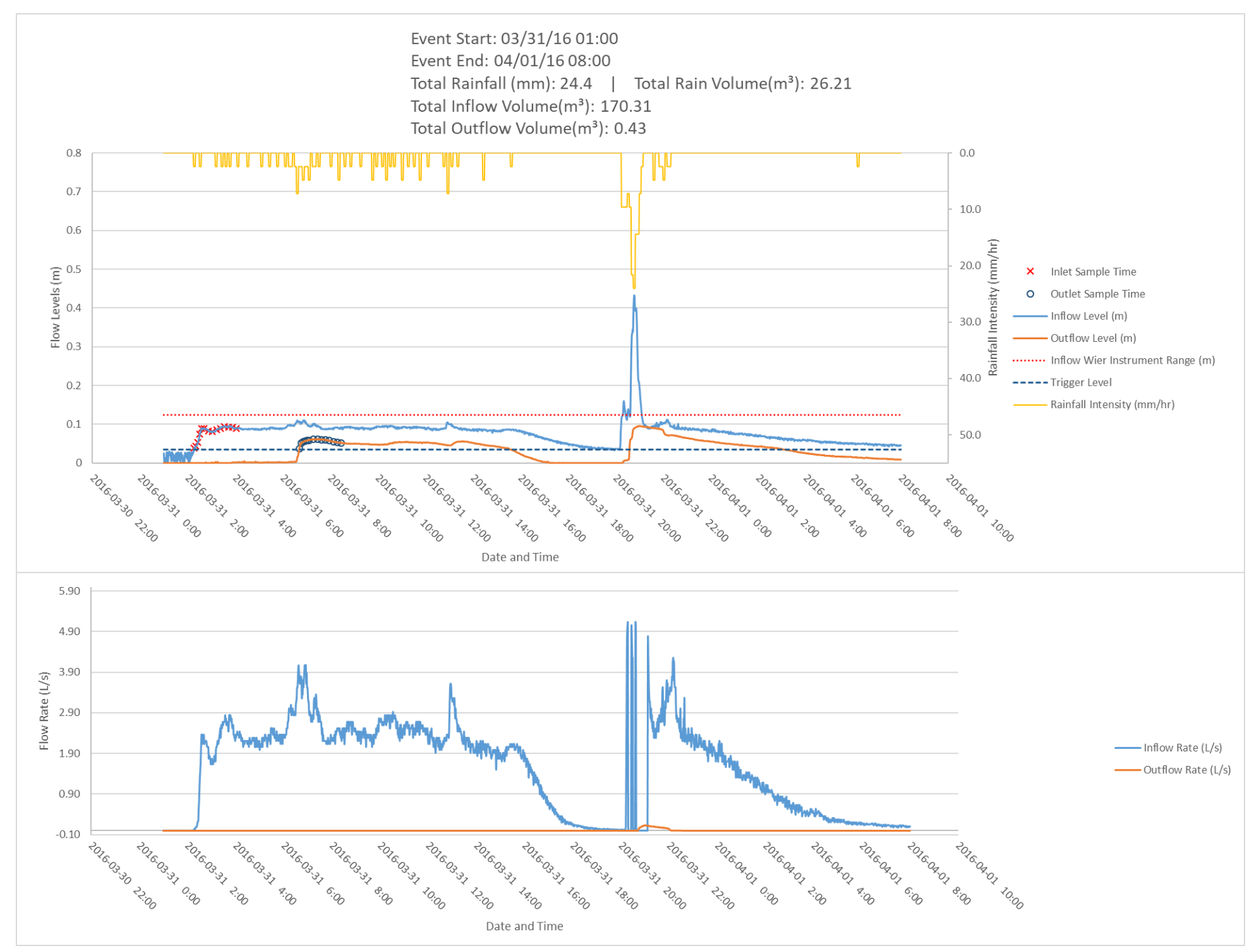




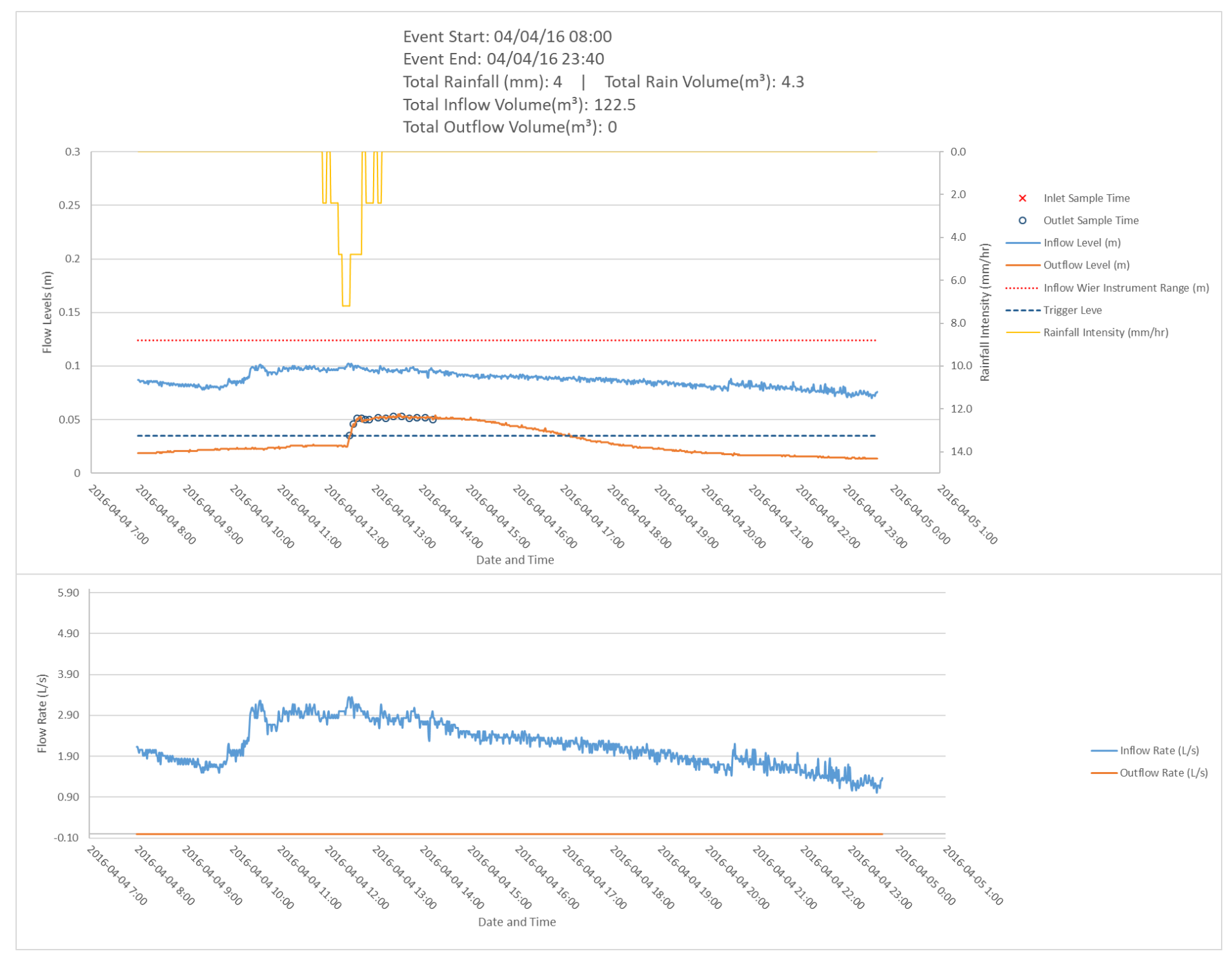




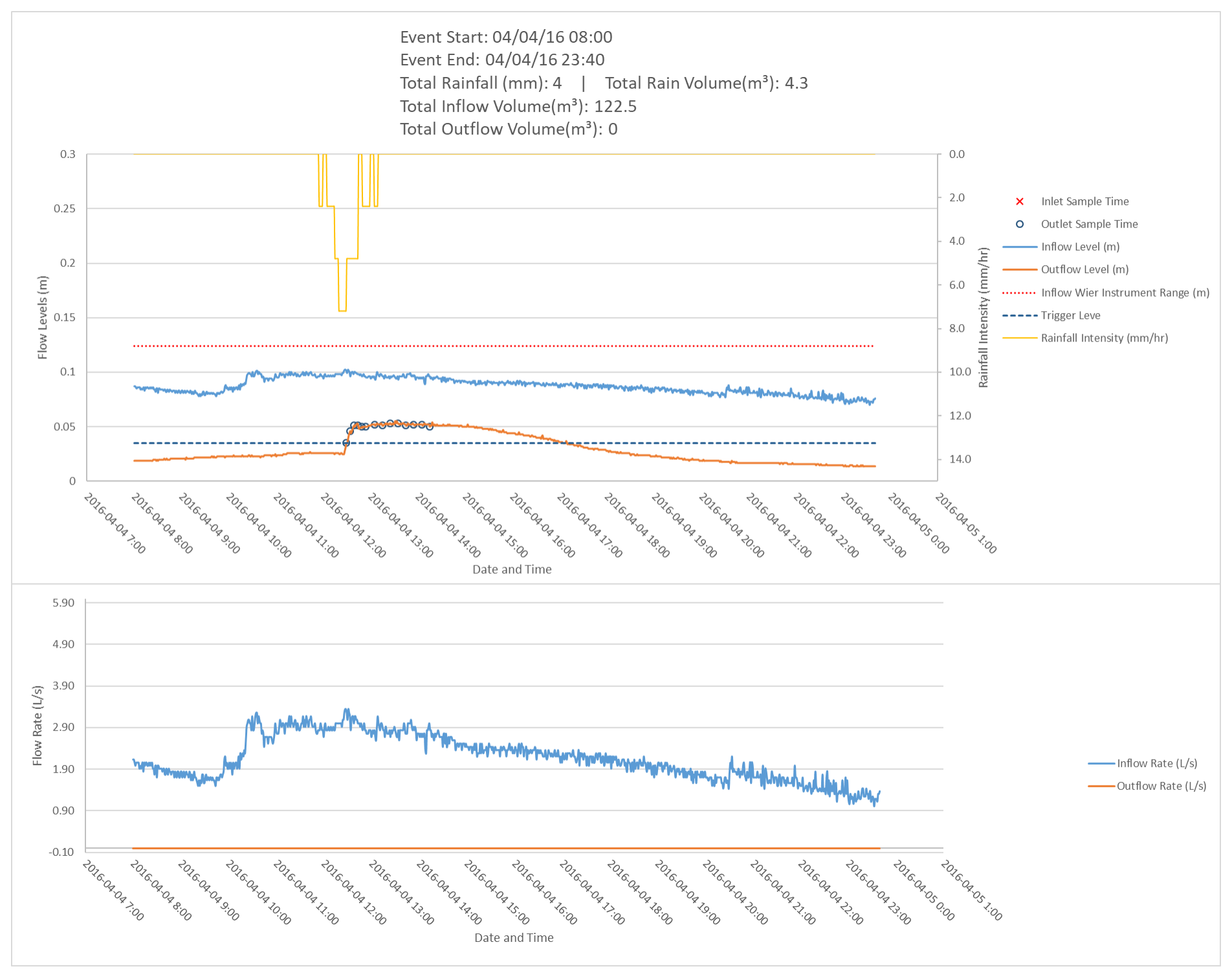




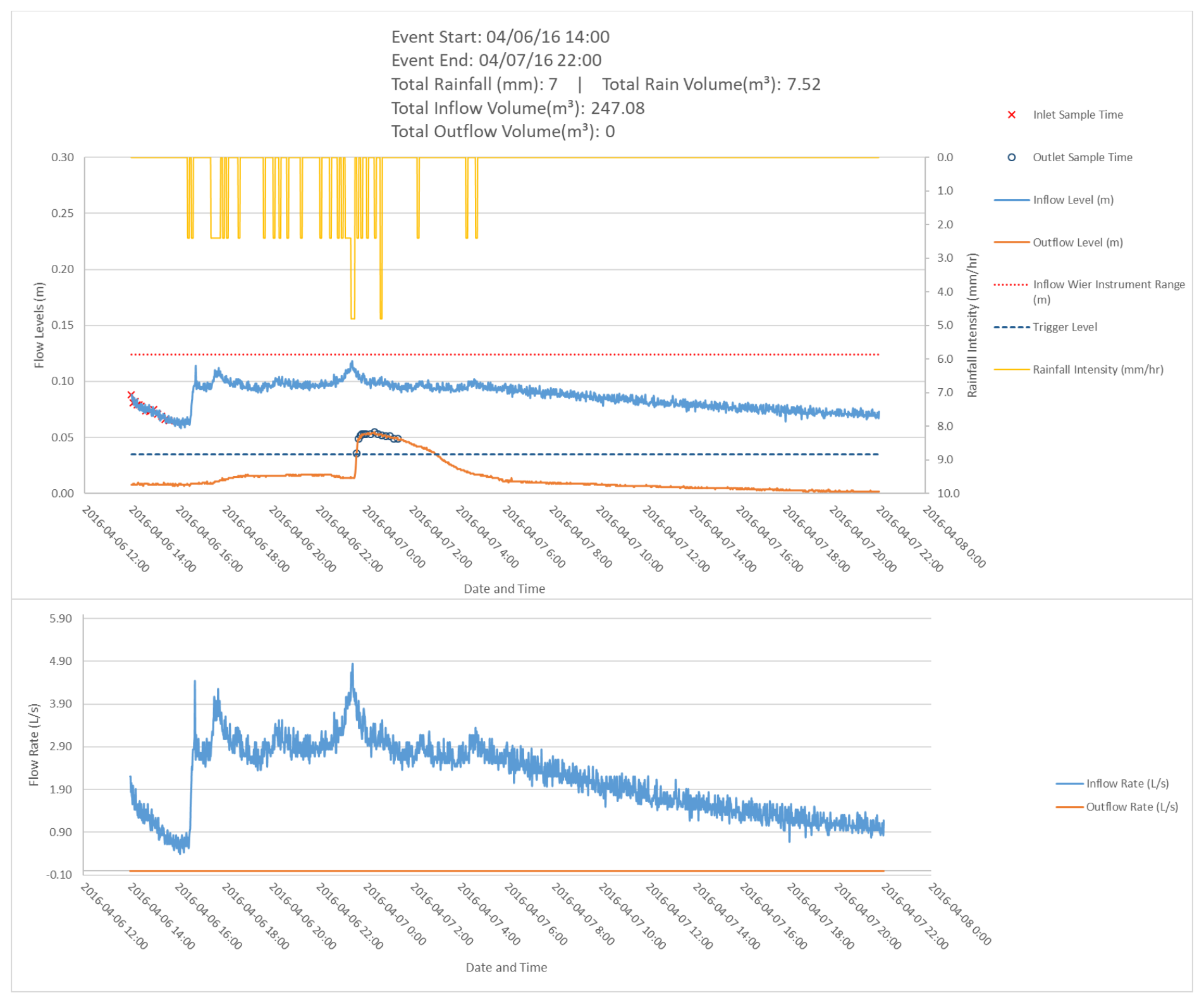




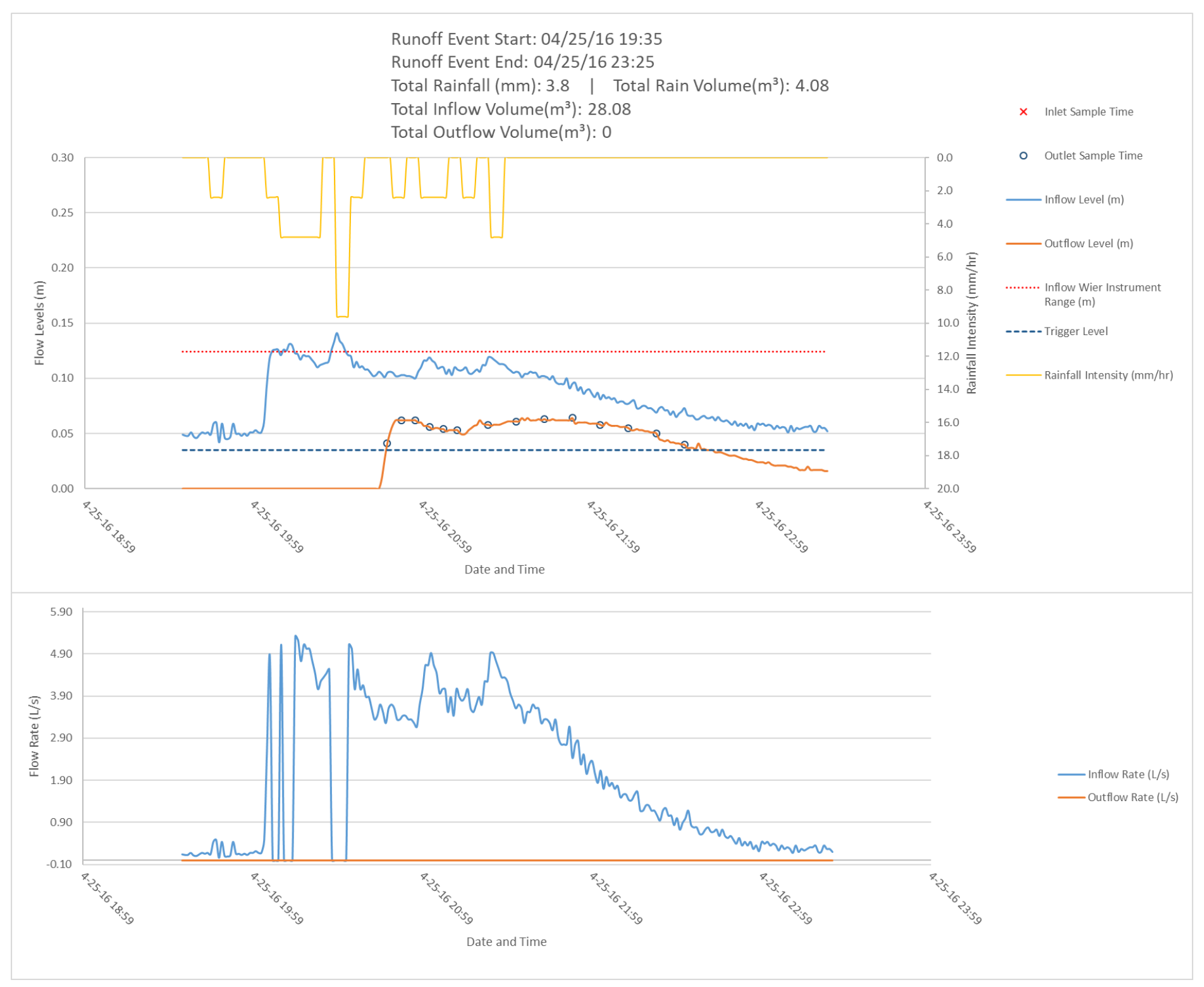




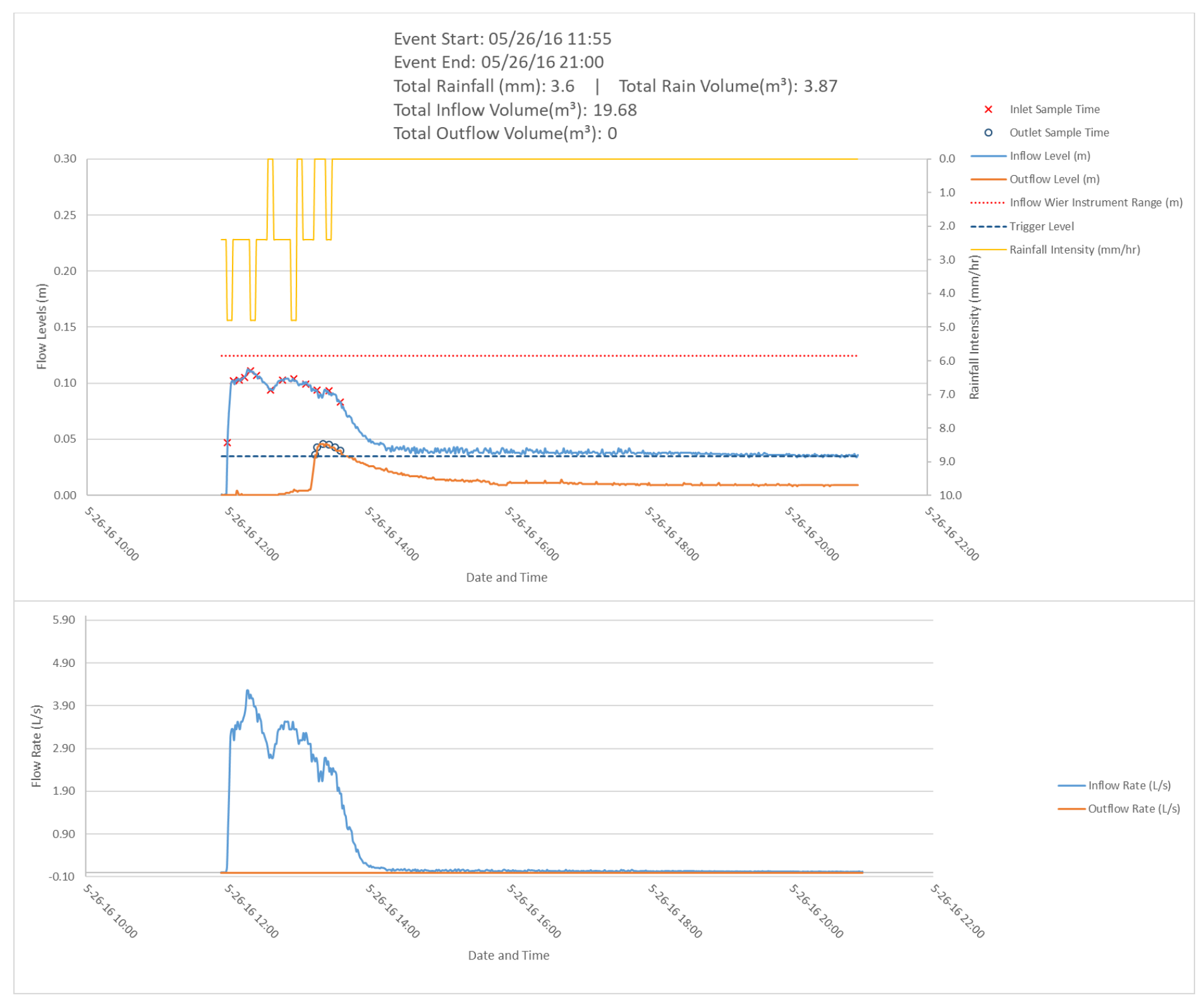




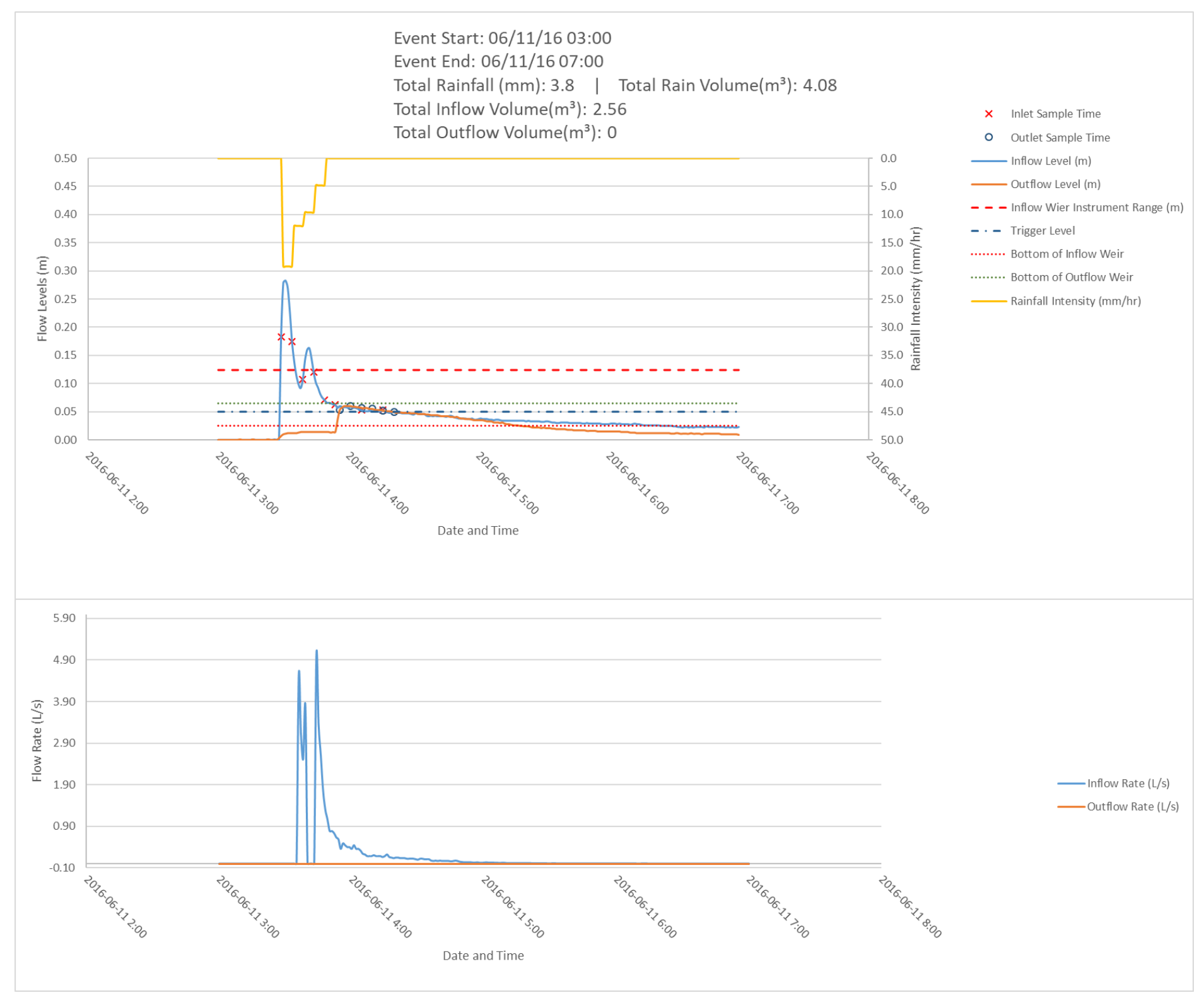




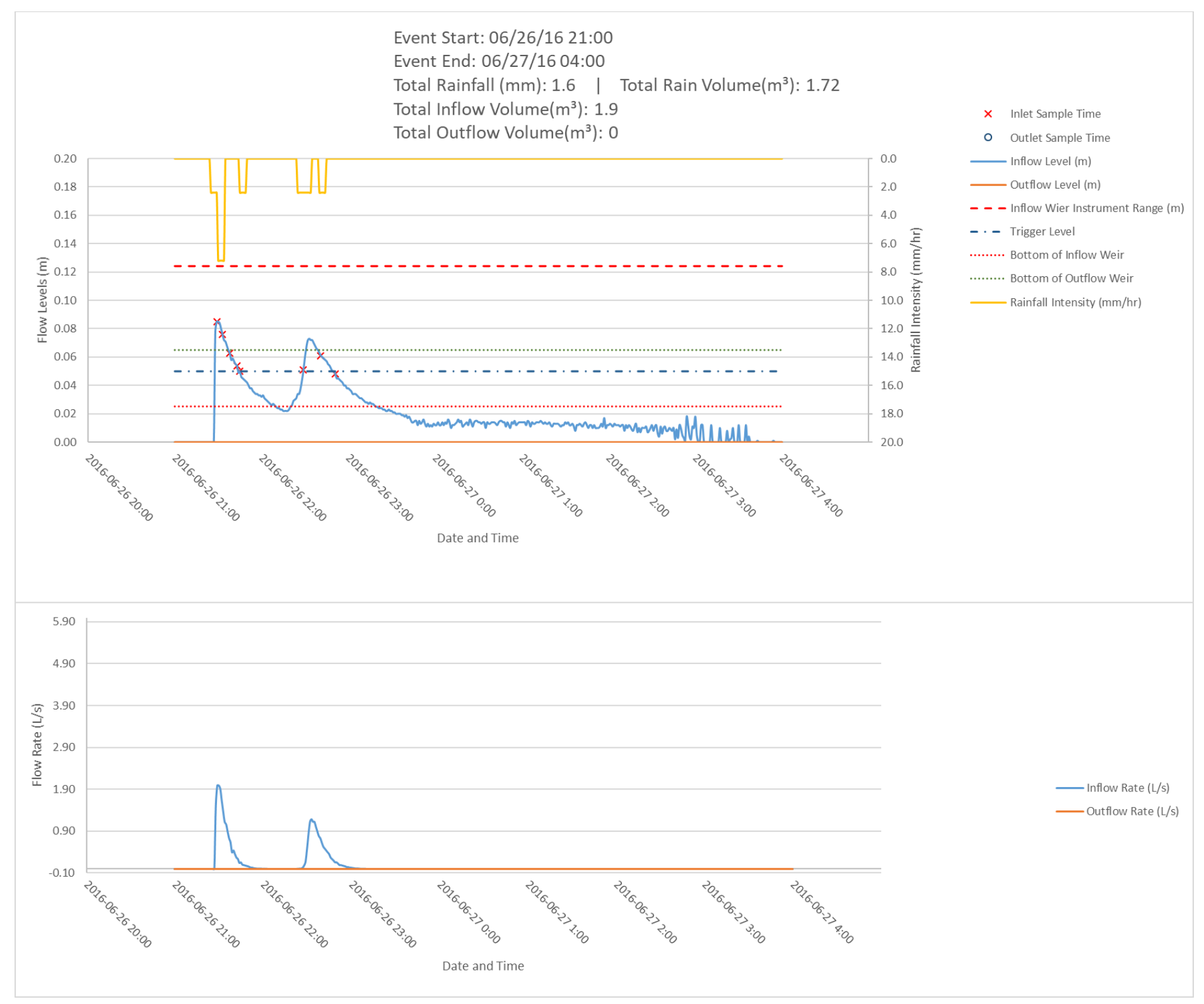




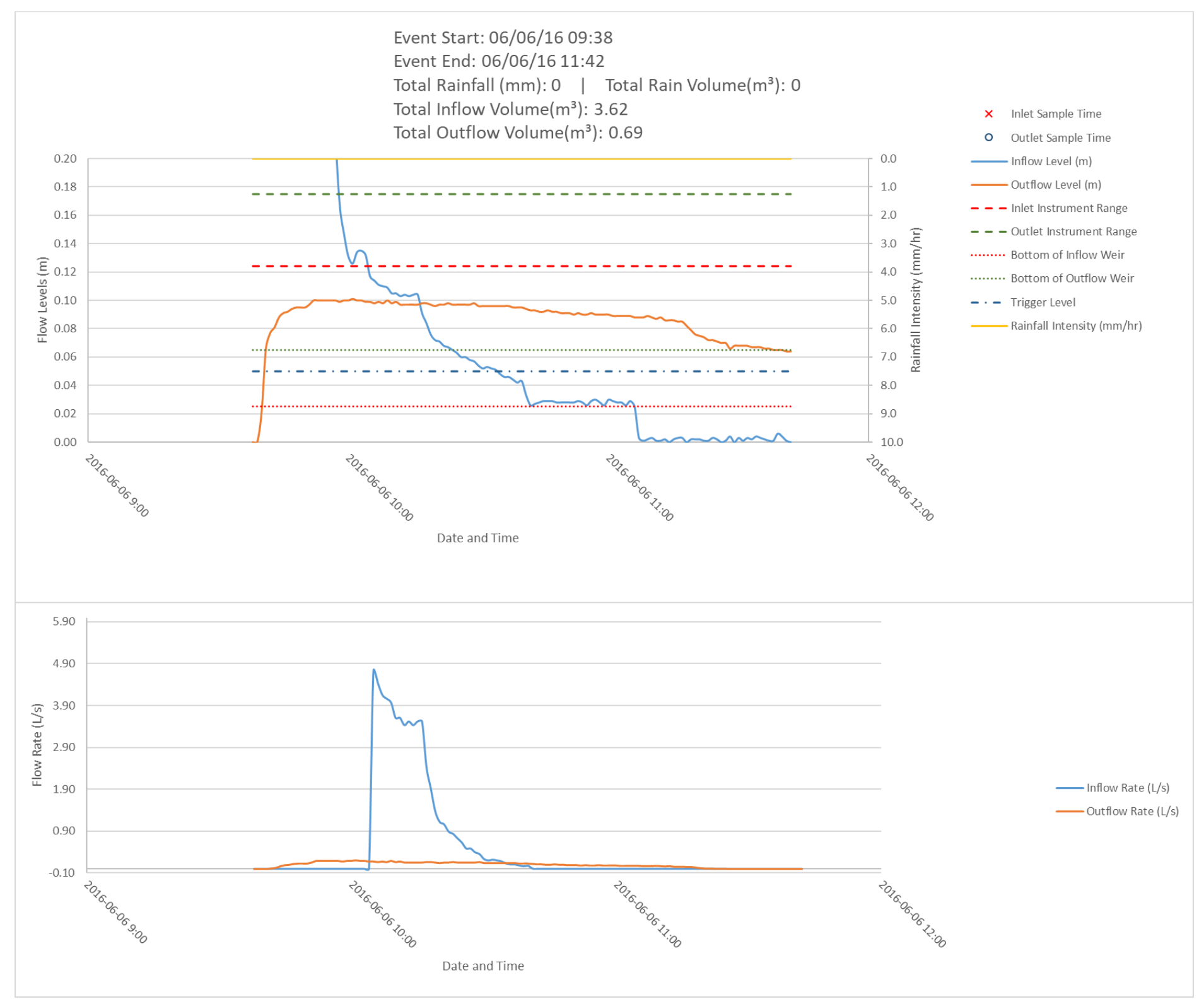




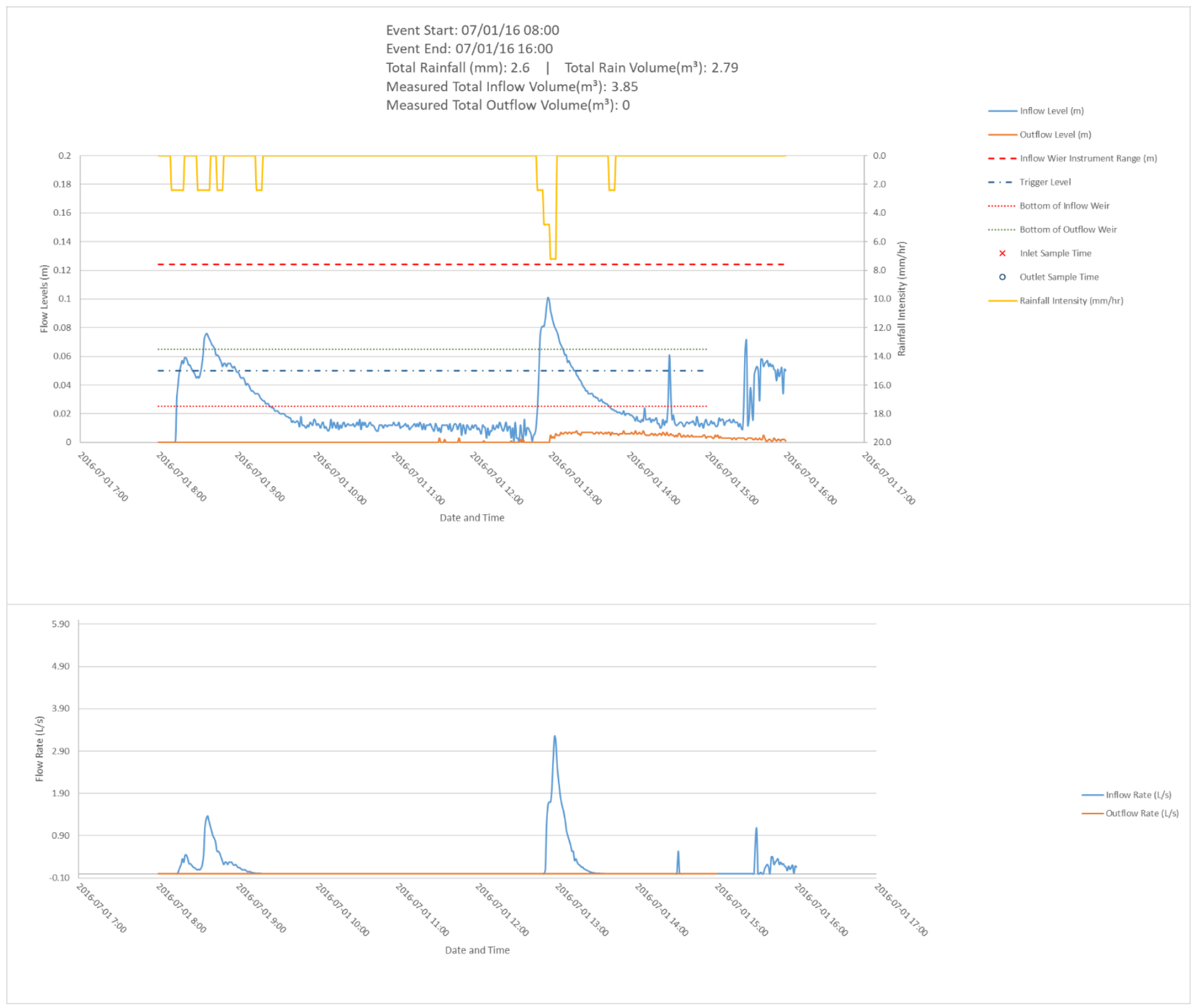

154 


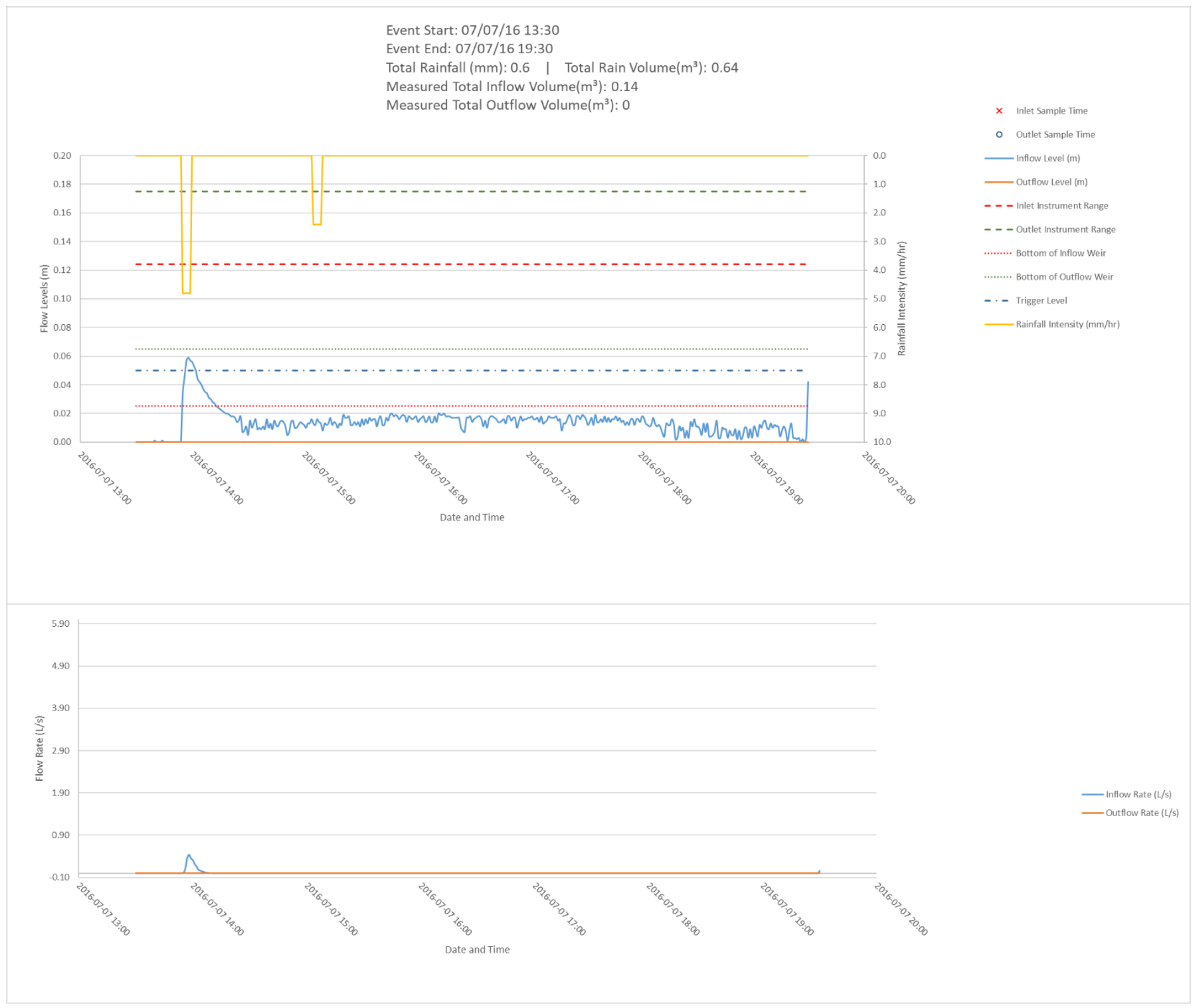

155 


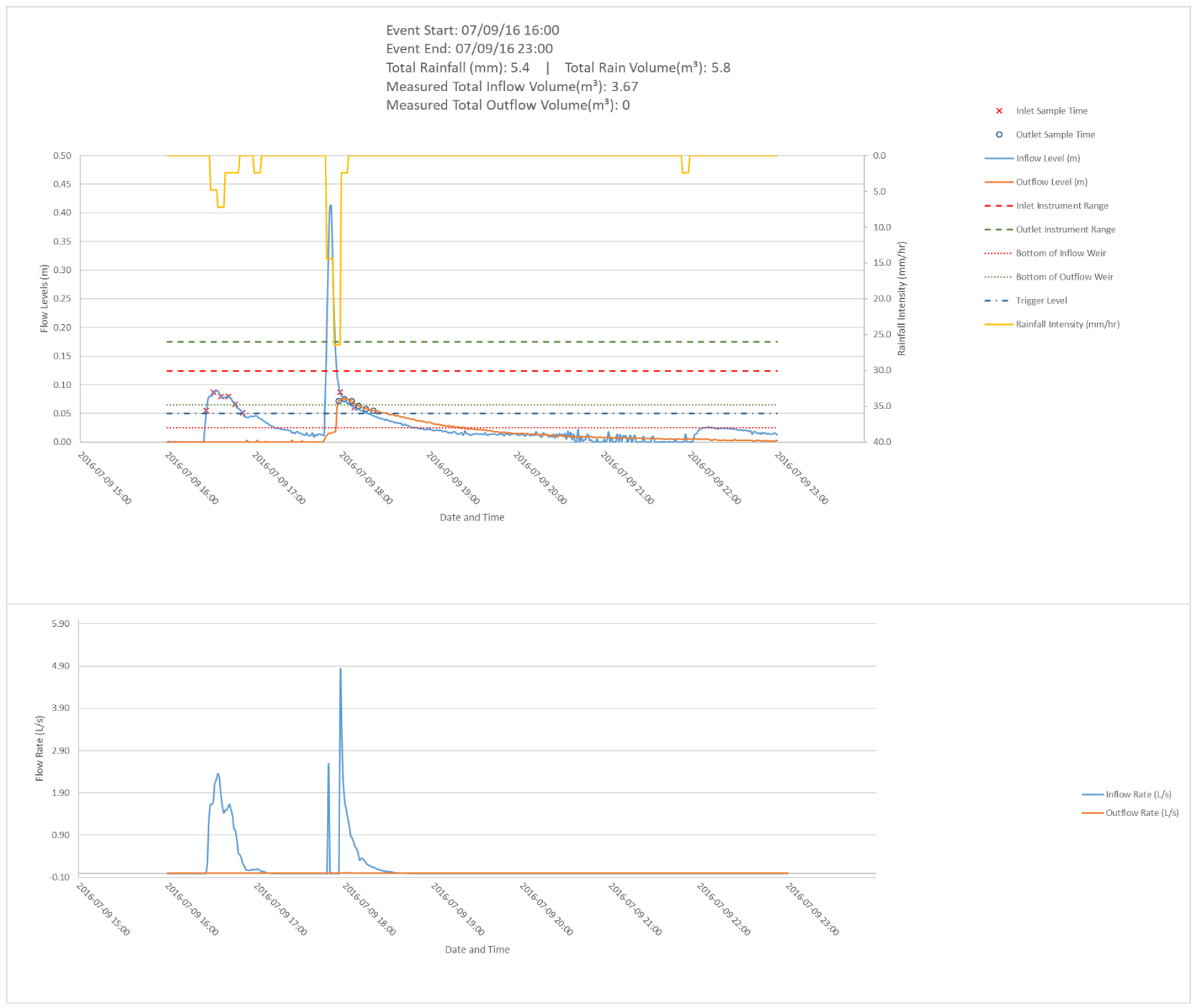

156 


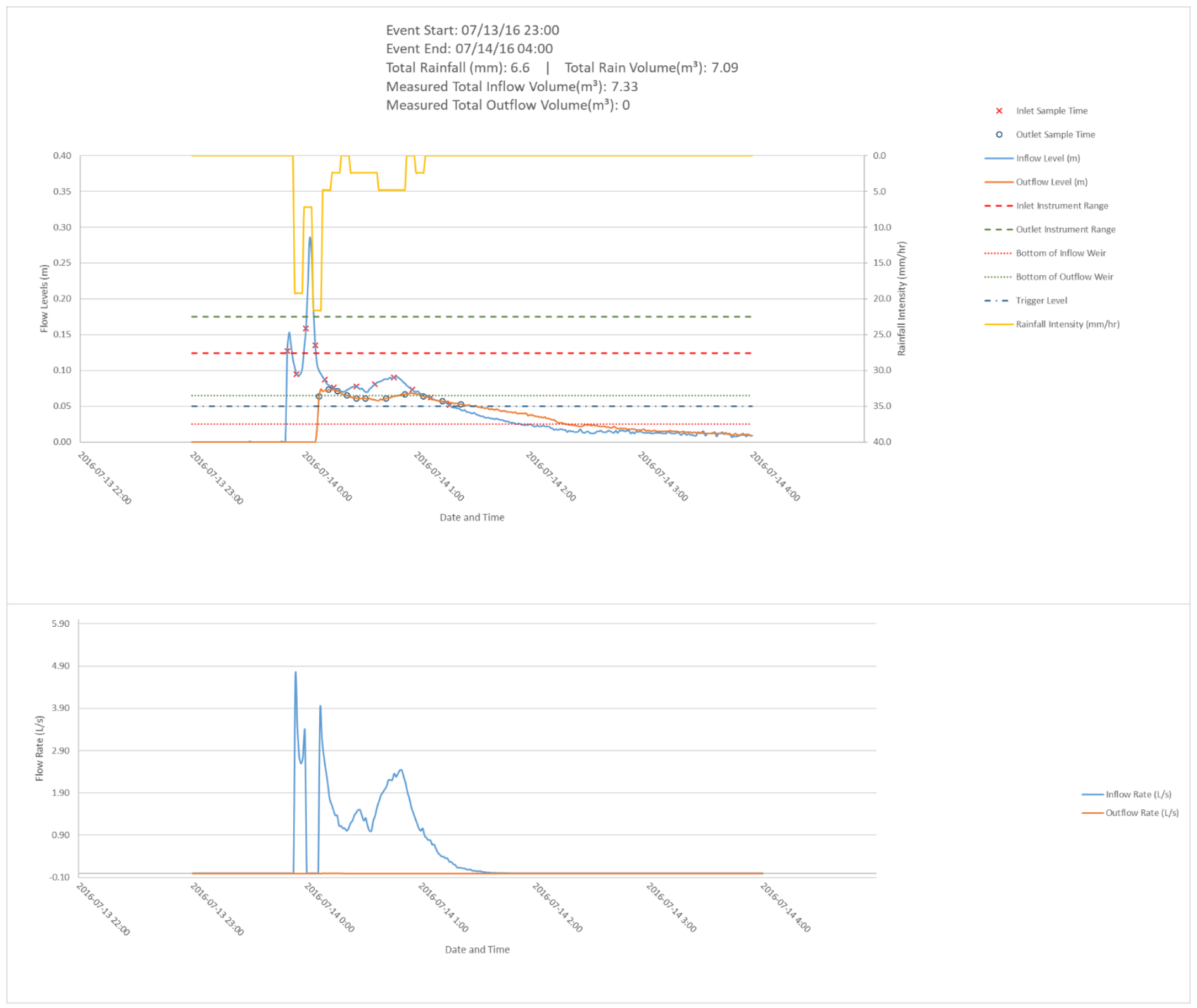

157 


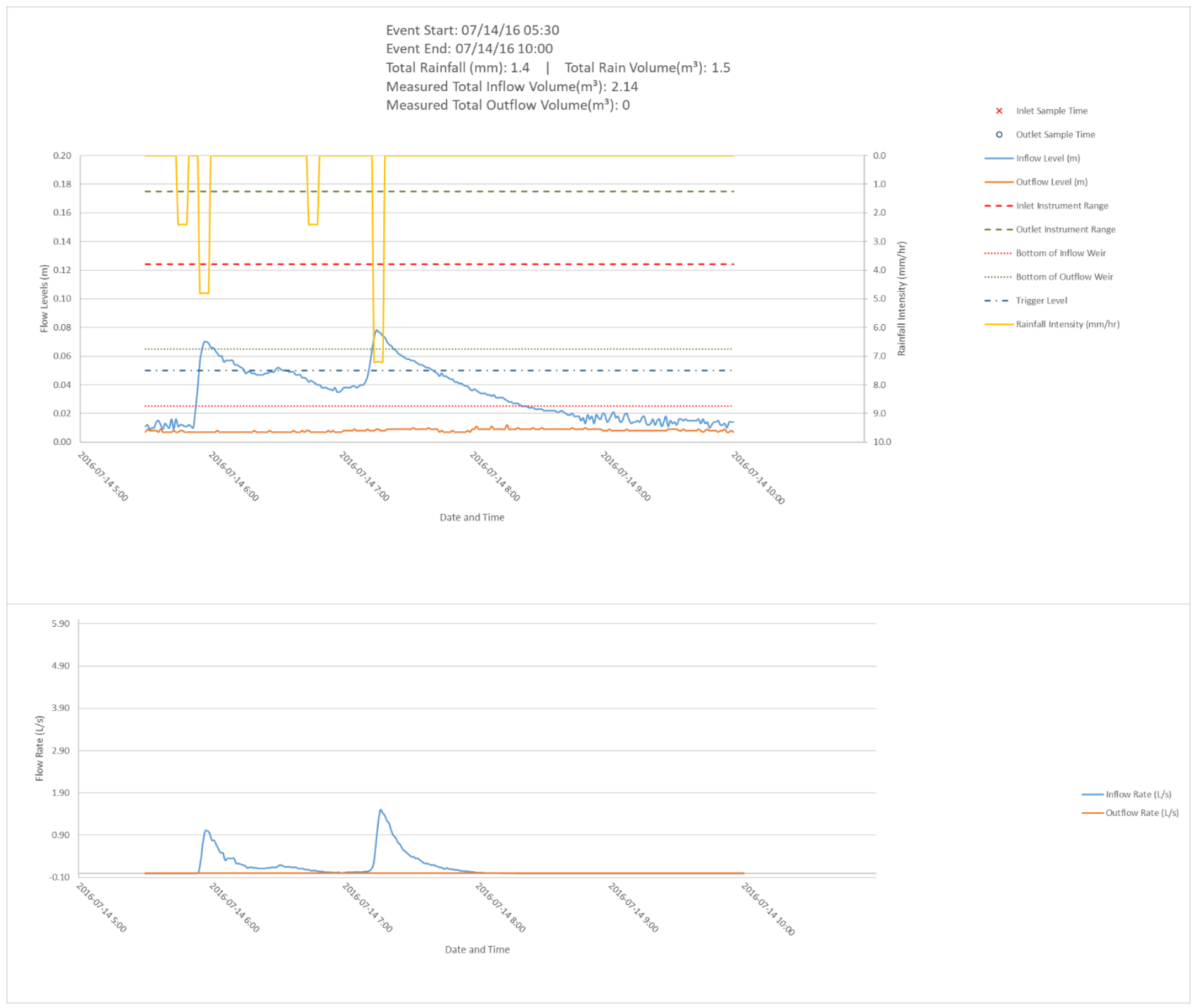

158 


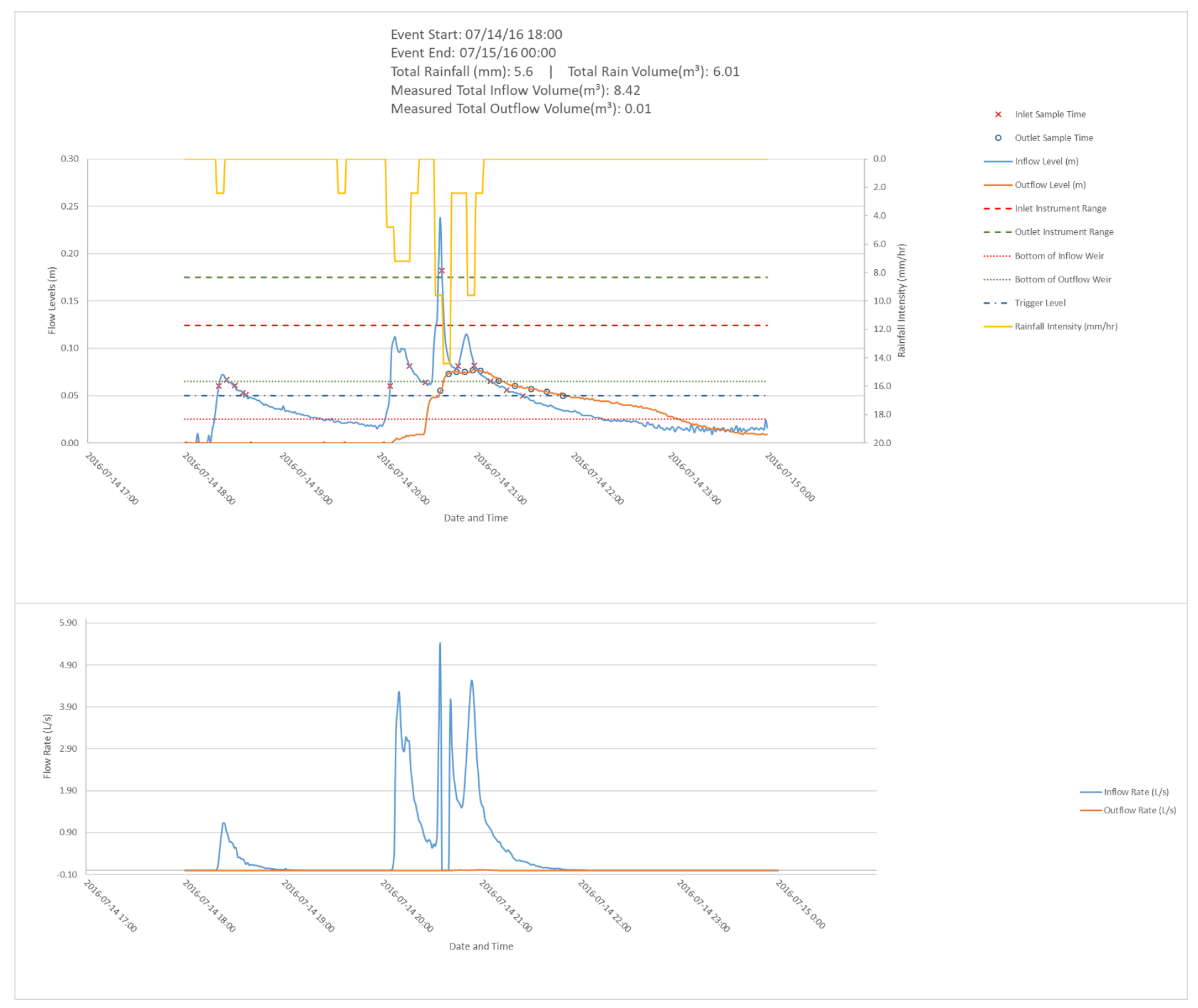




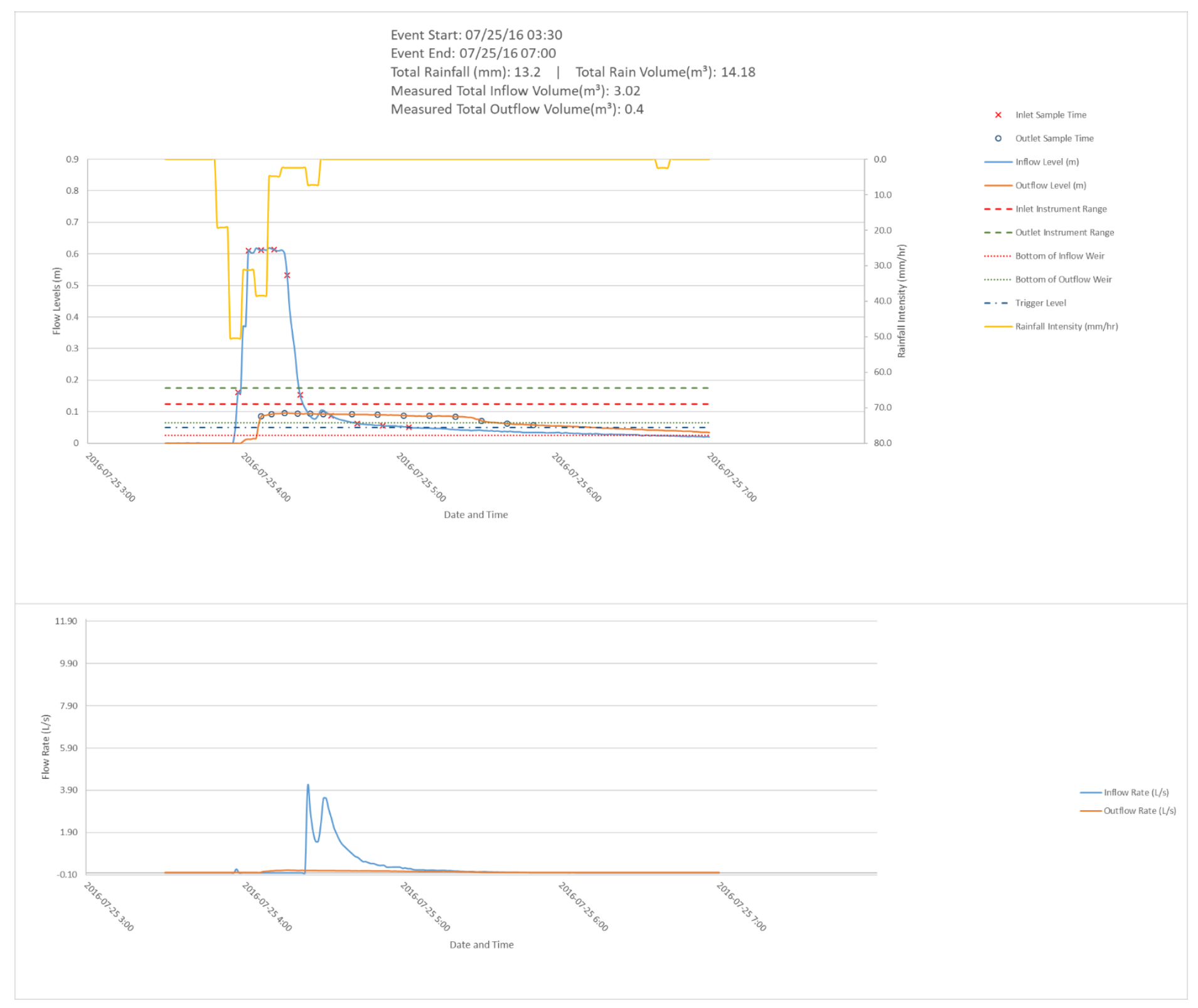




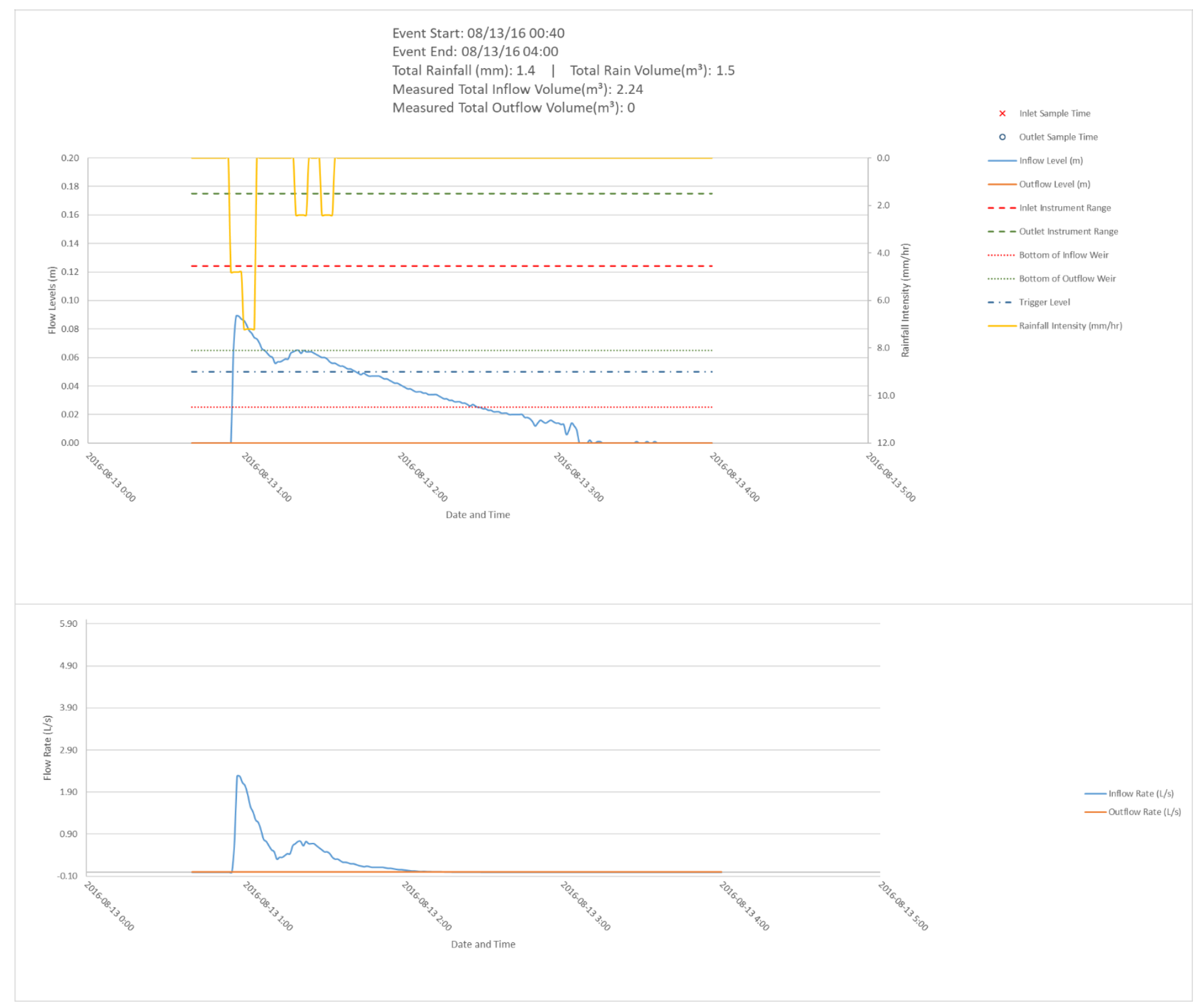




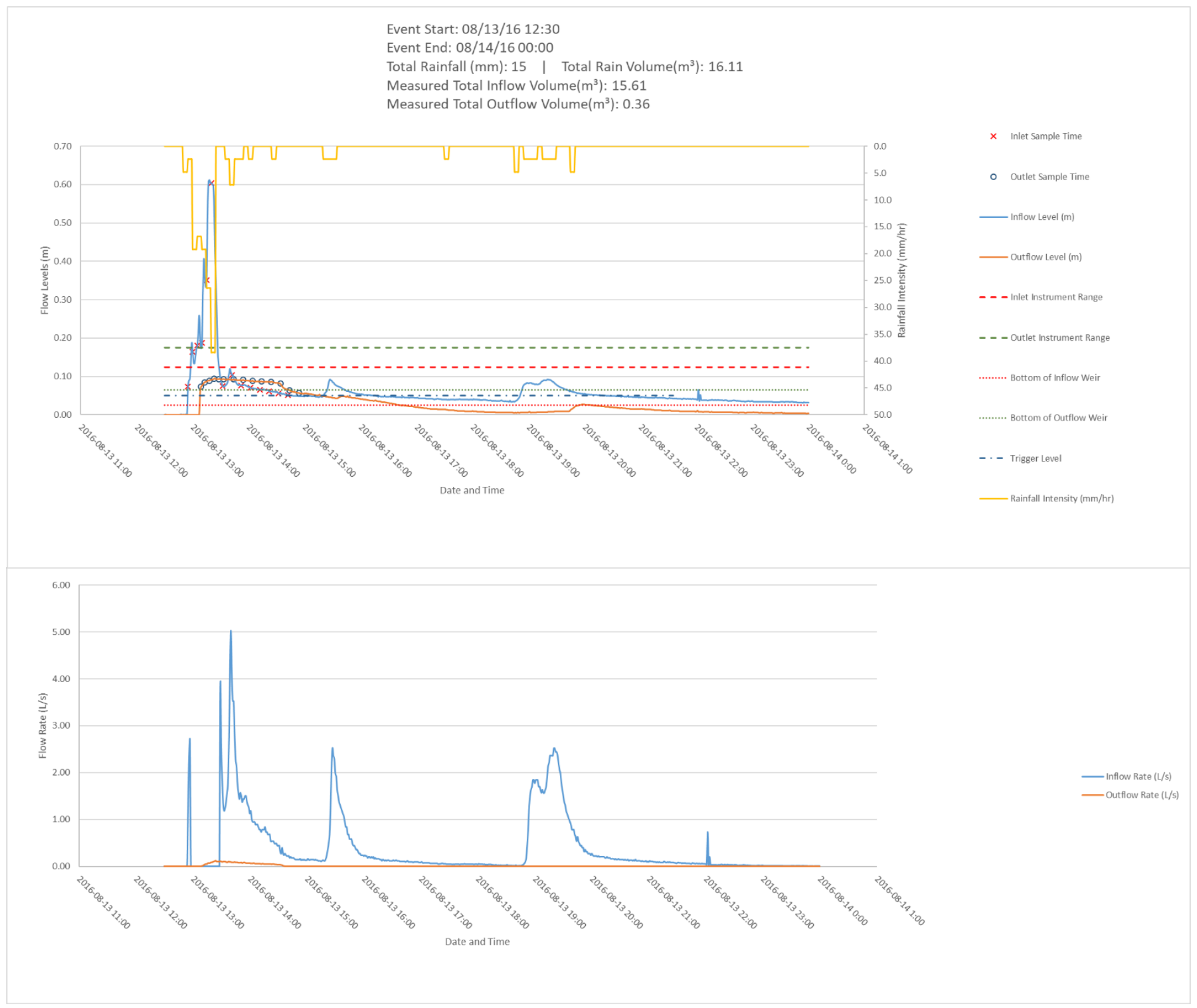

162 


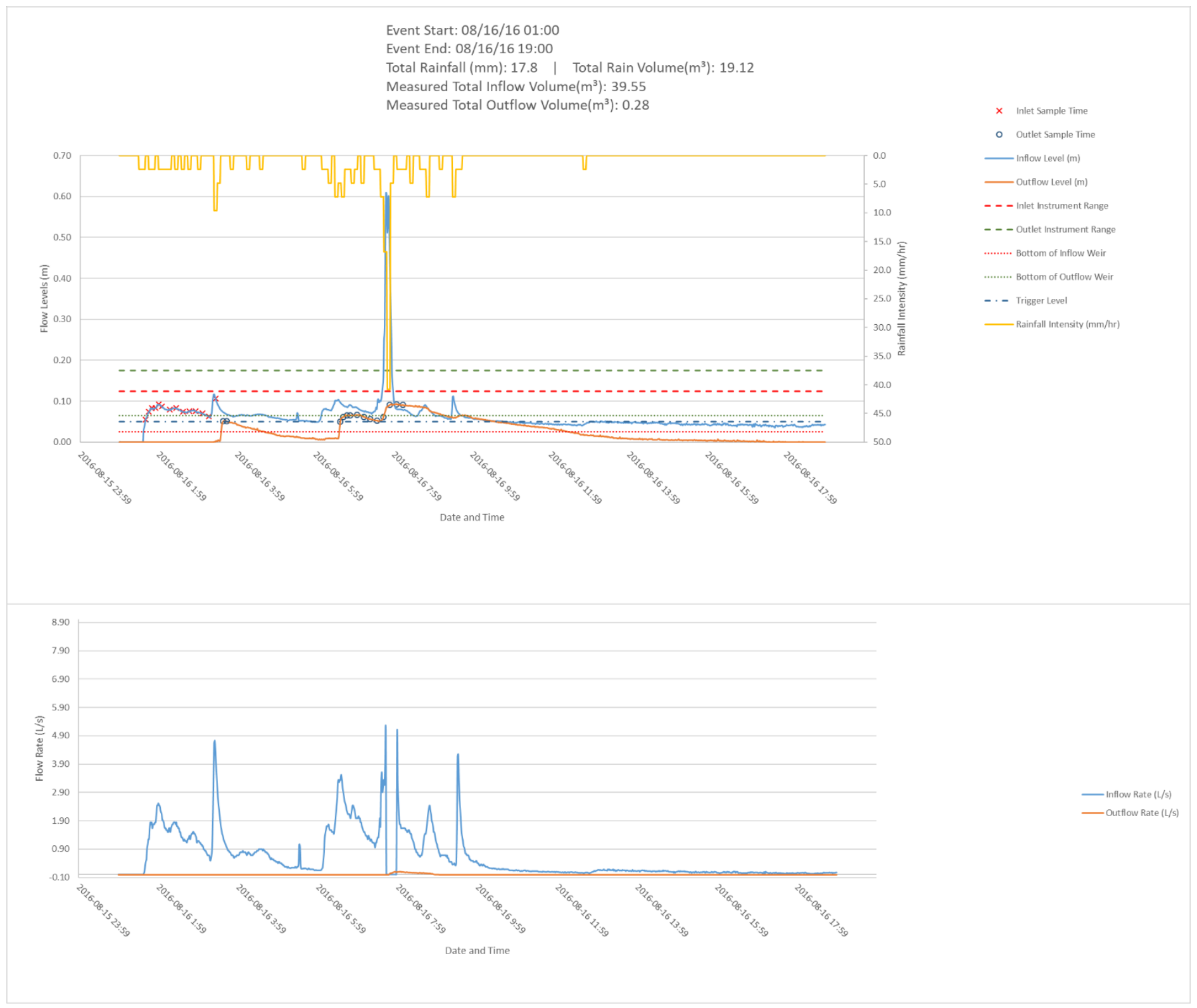

163 


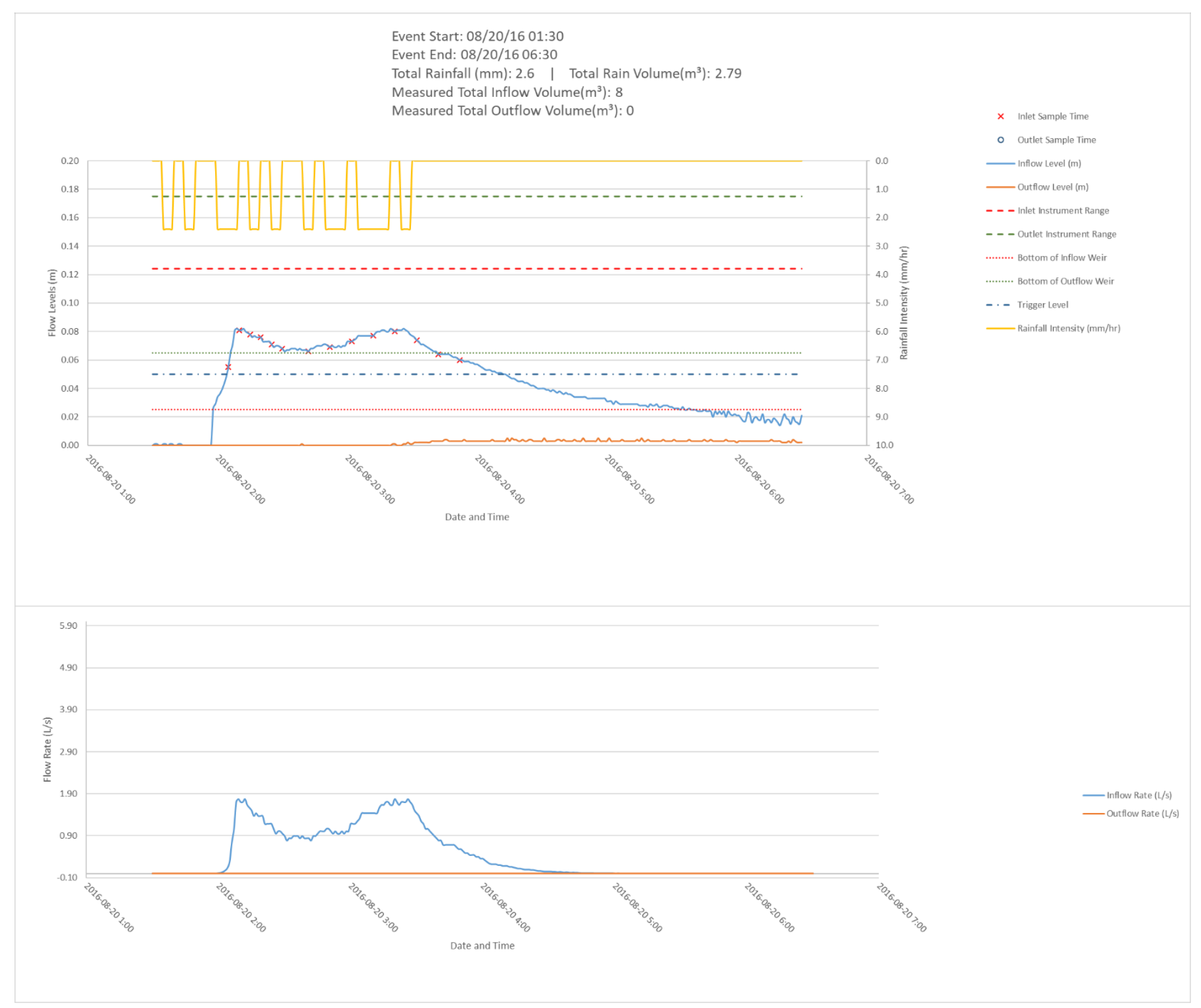




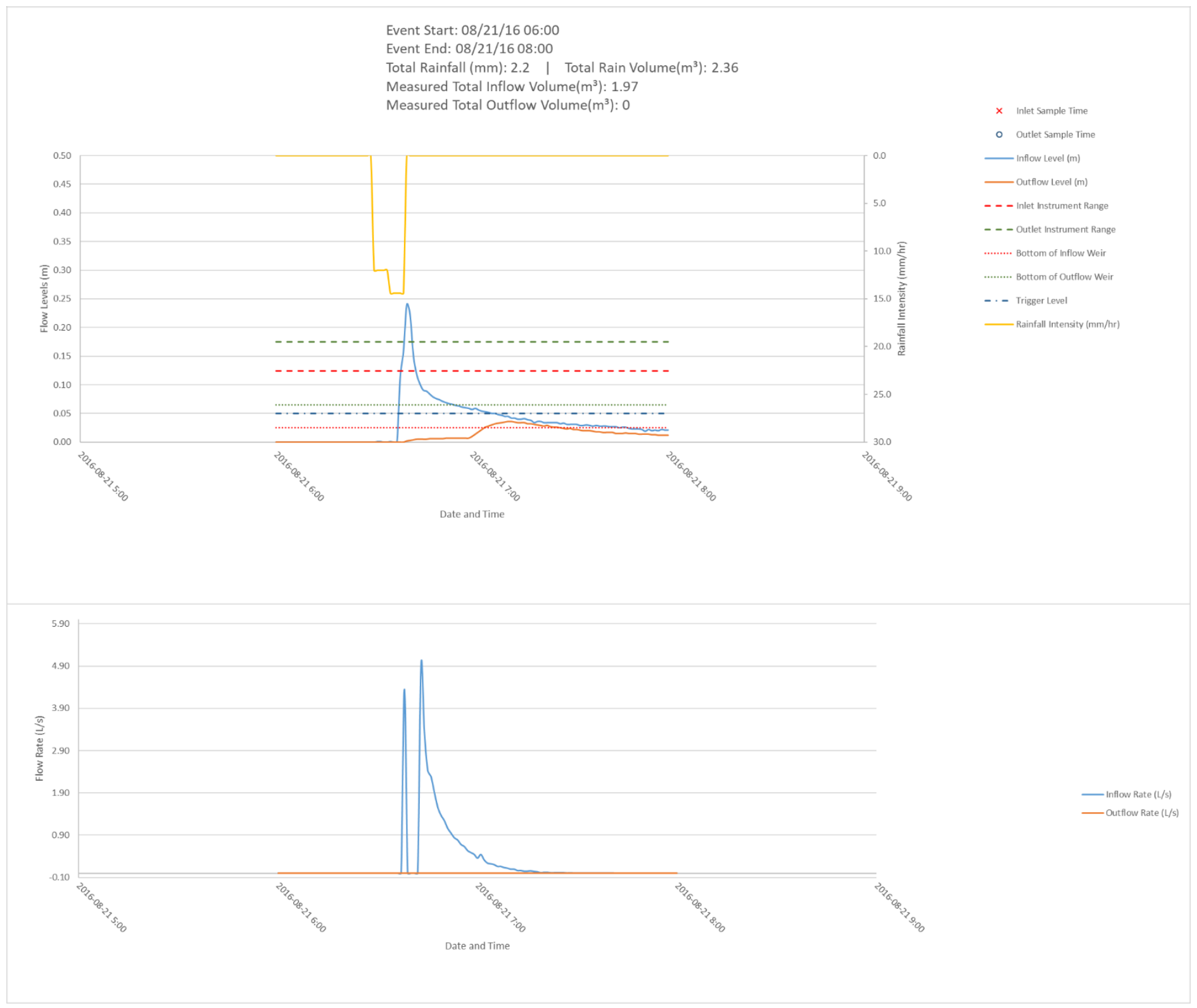

165 


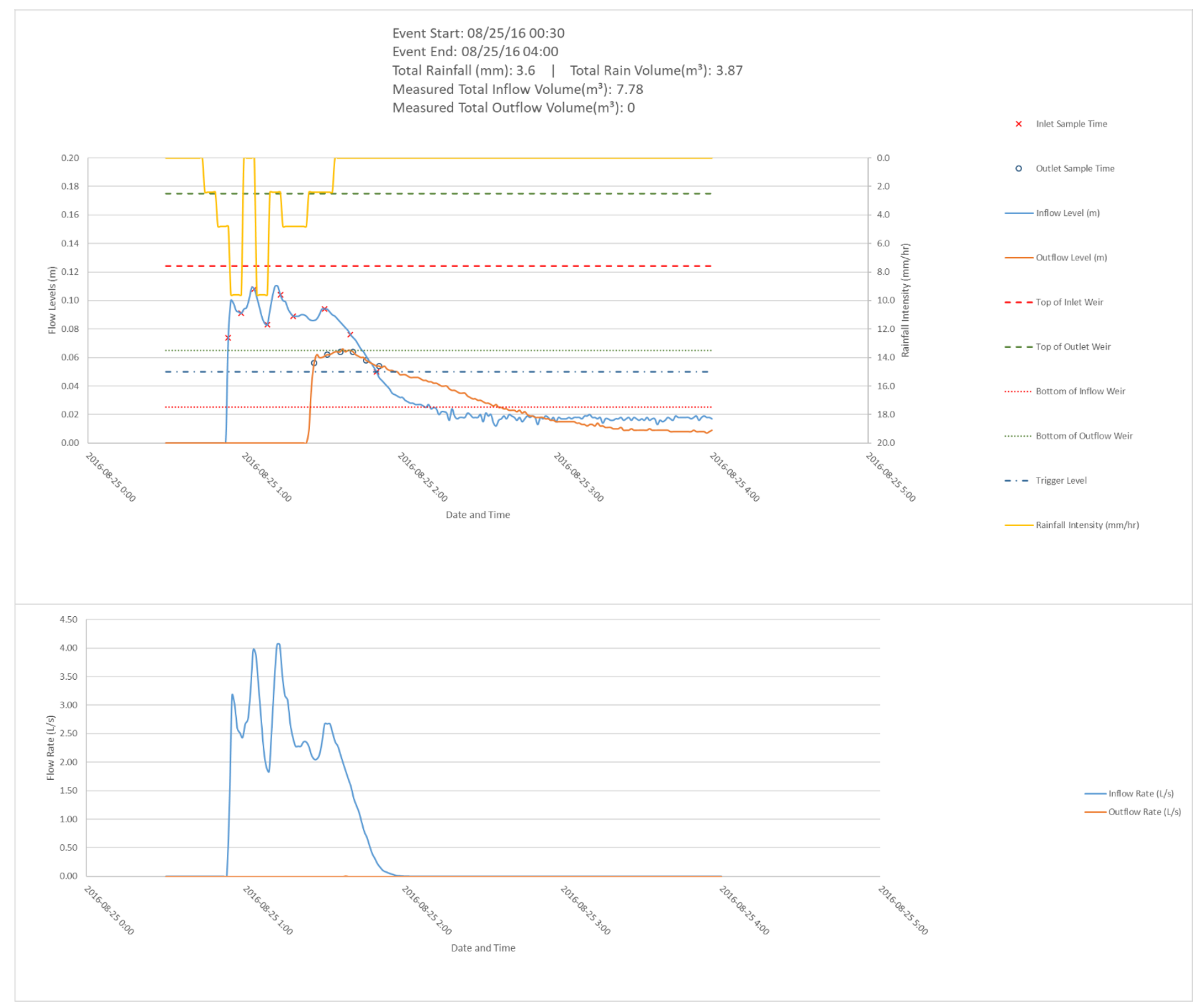




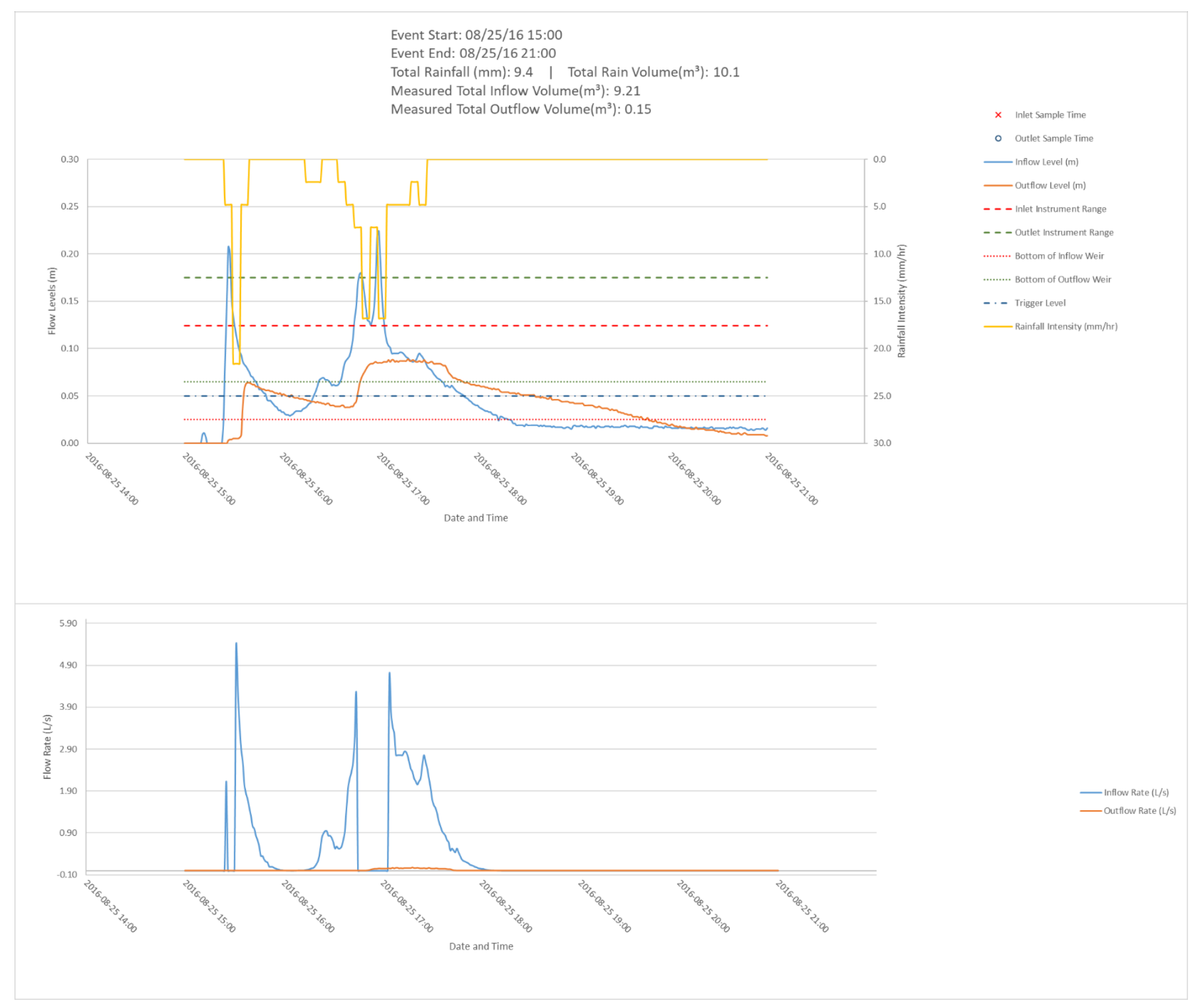




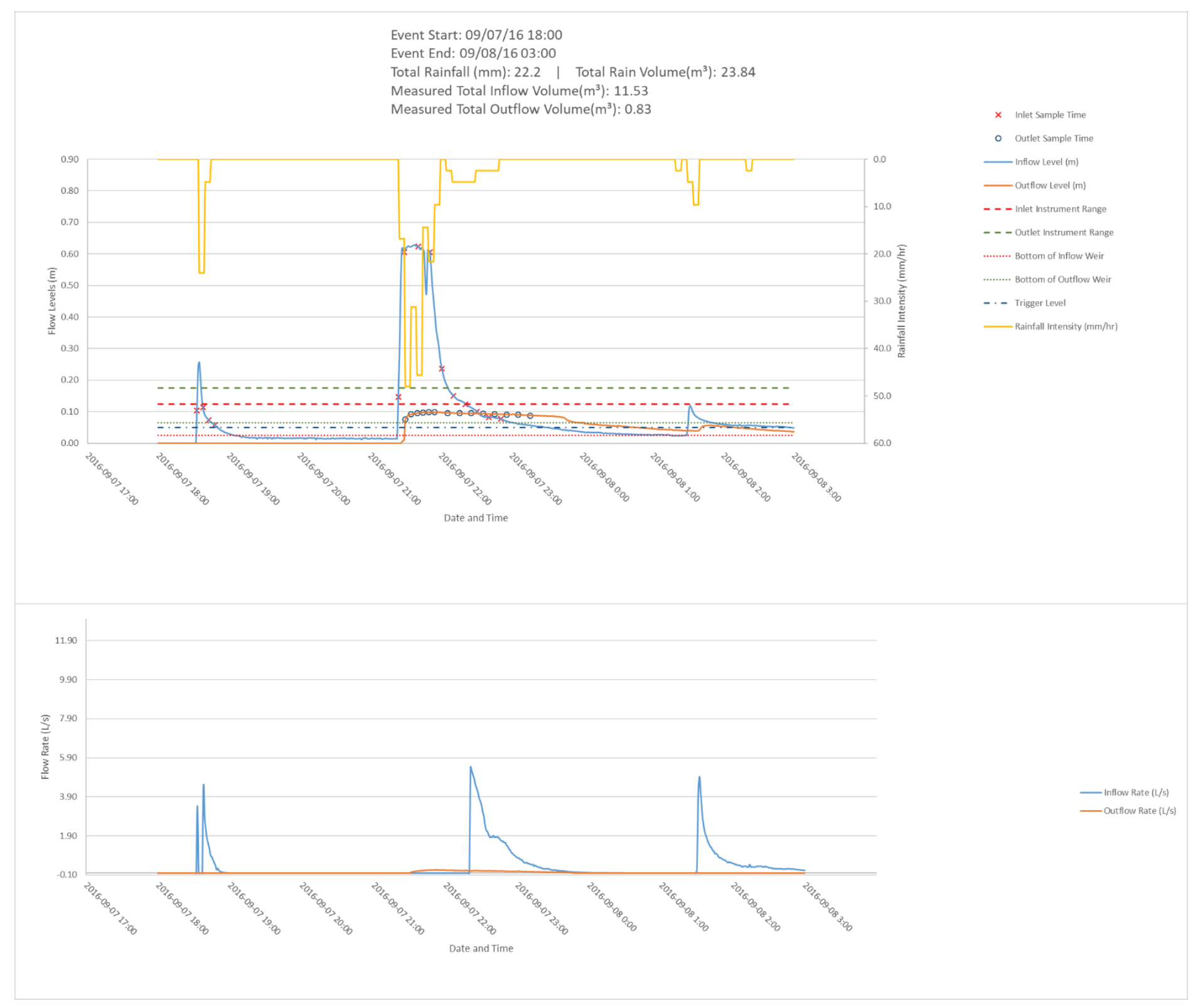




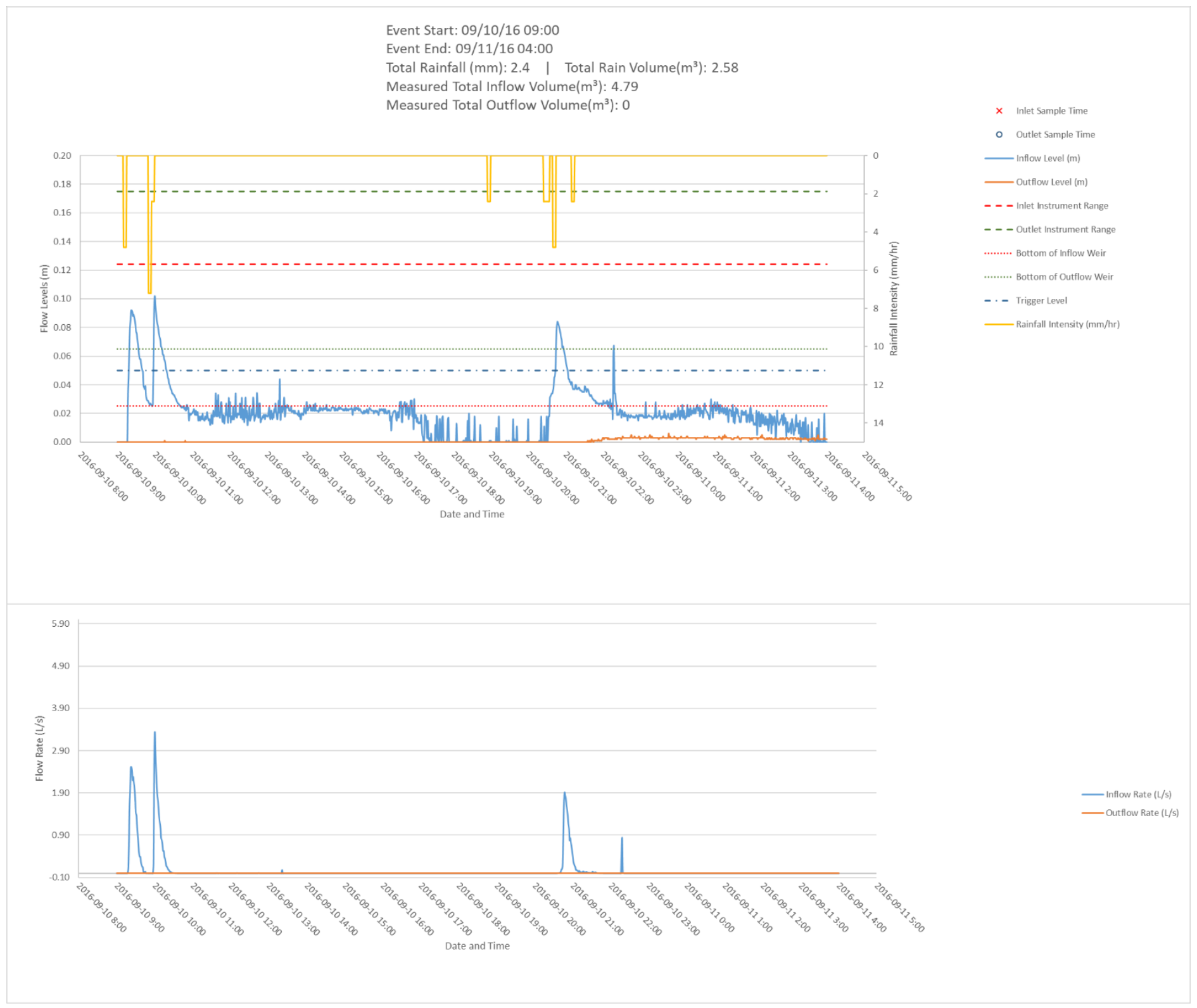

169 


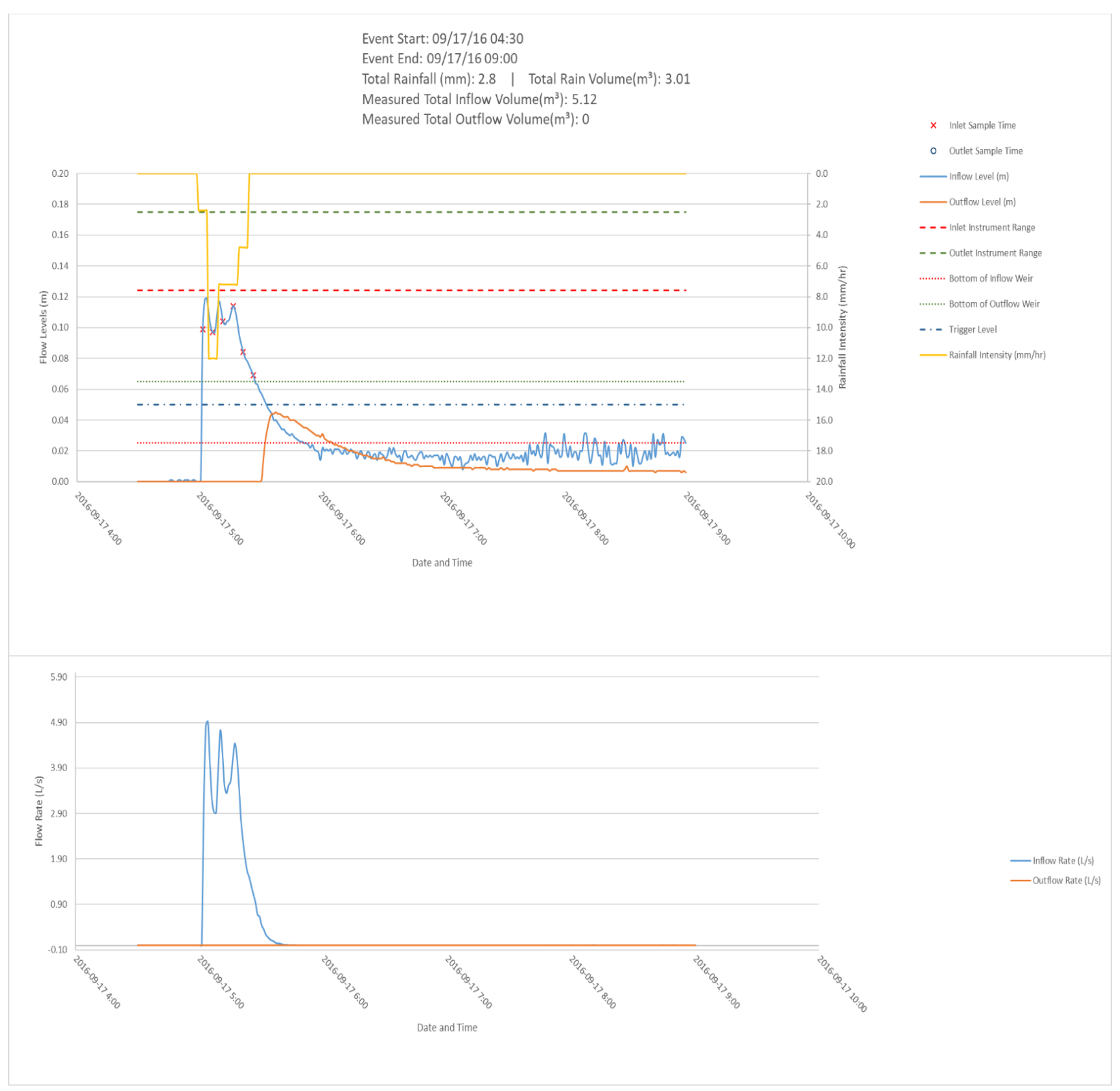




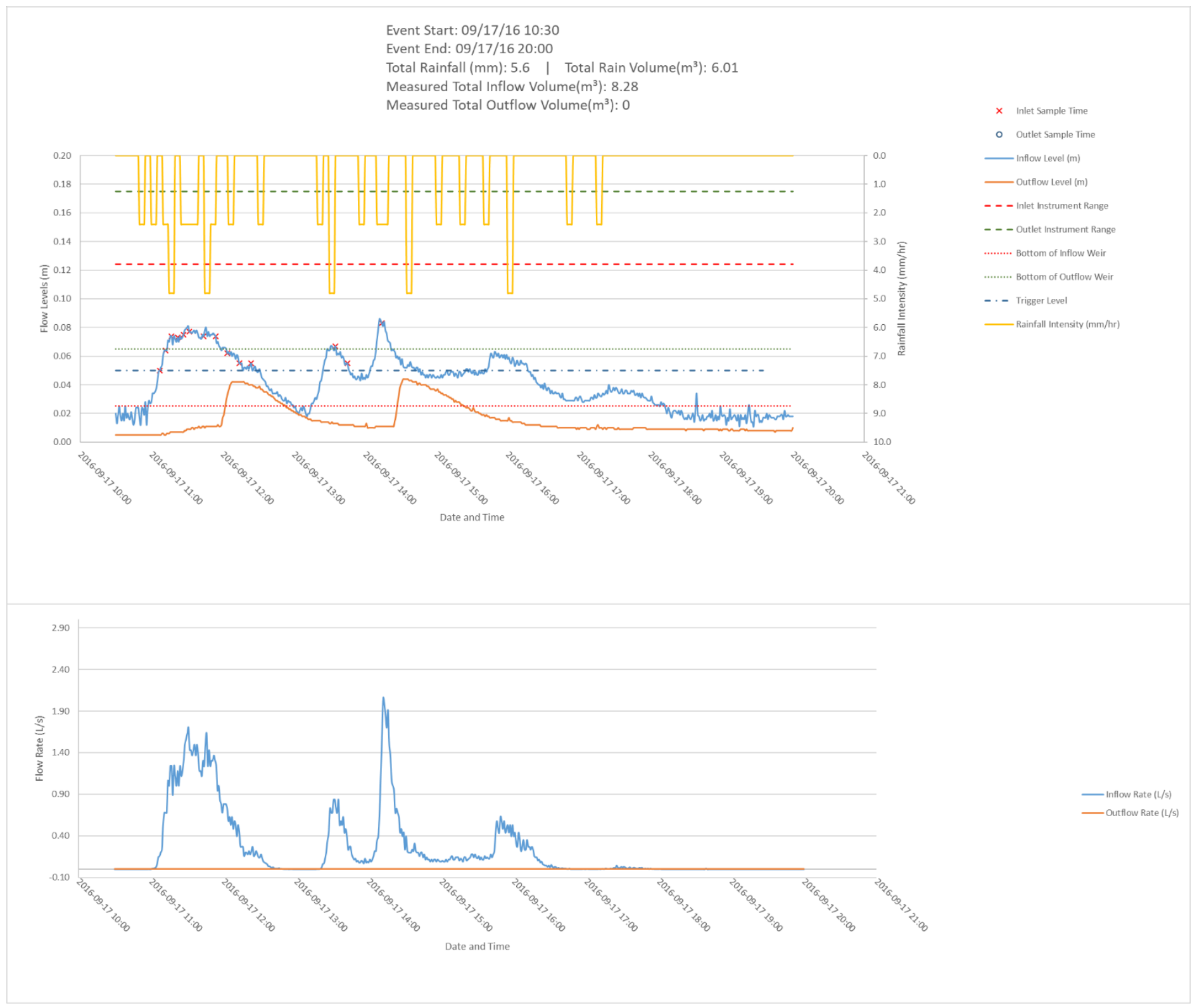

171 


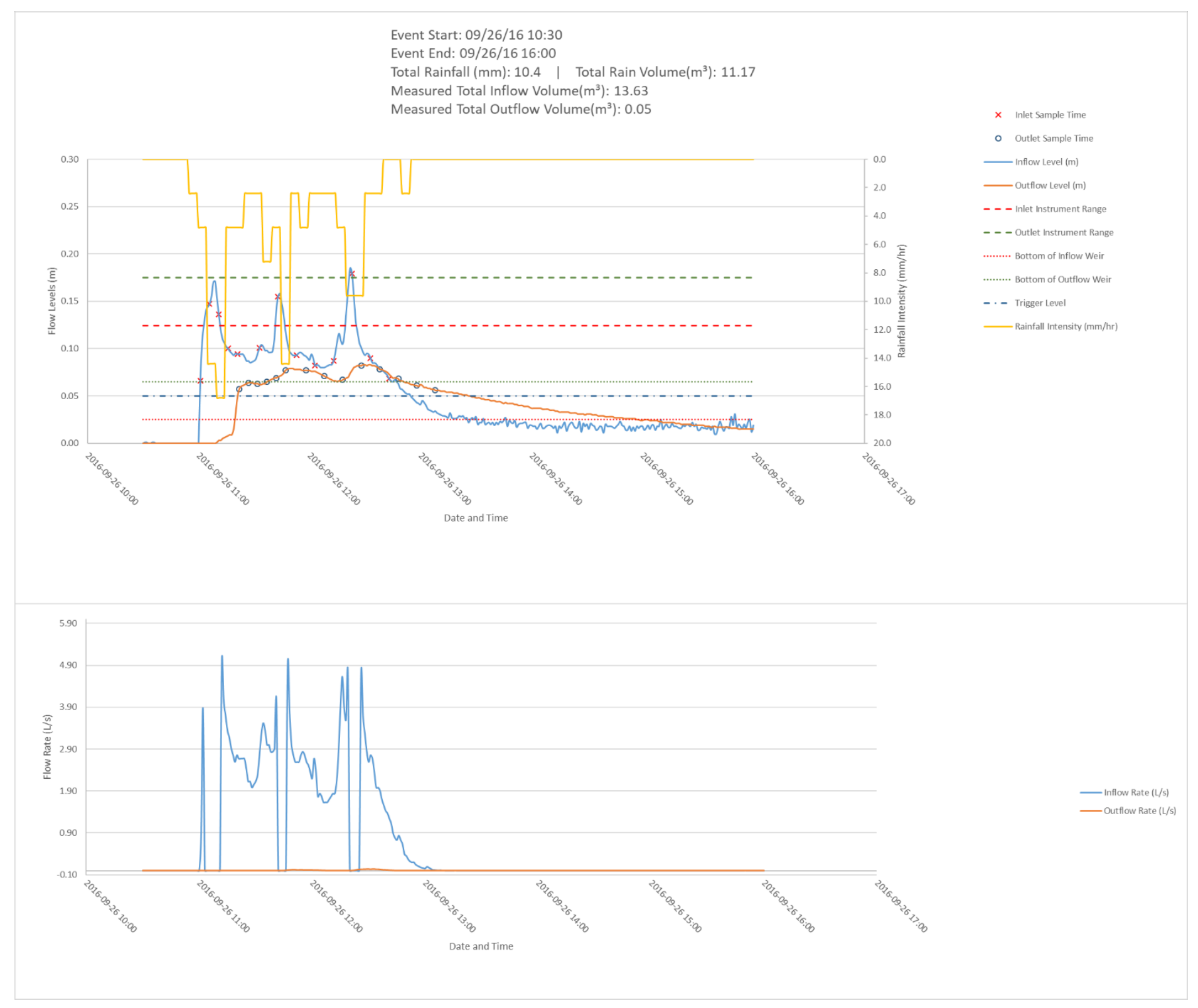




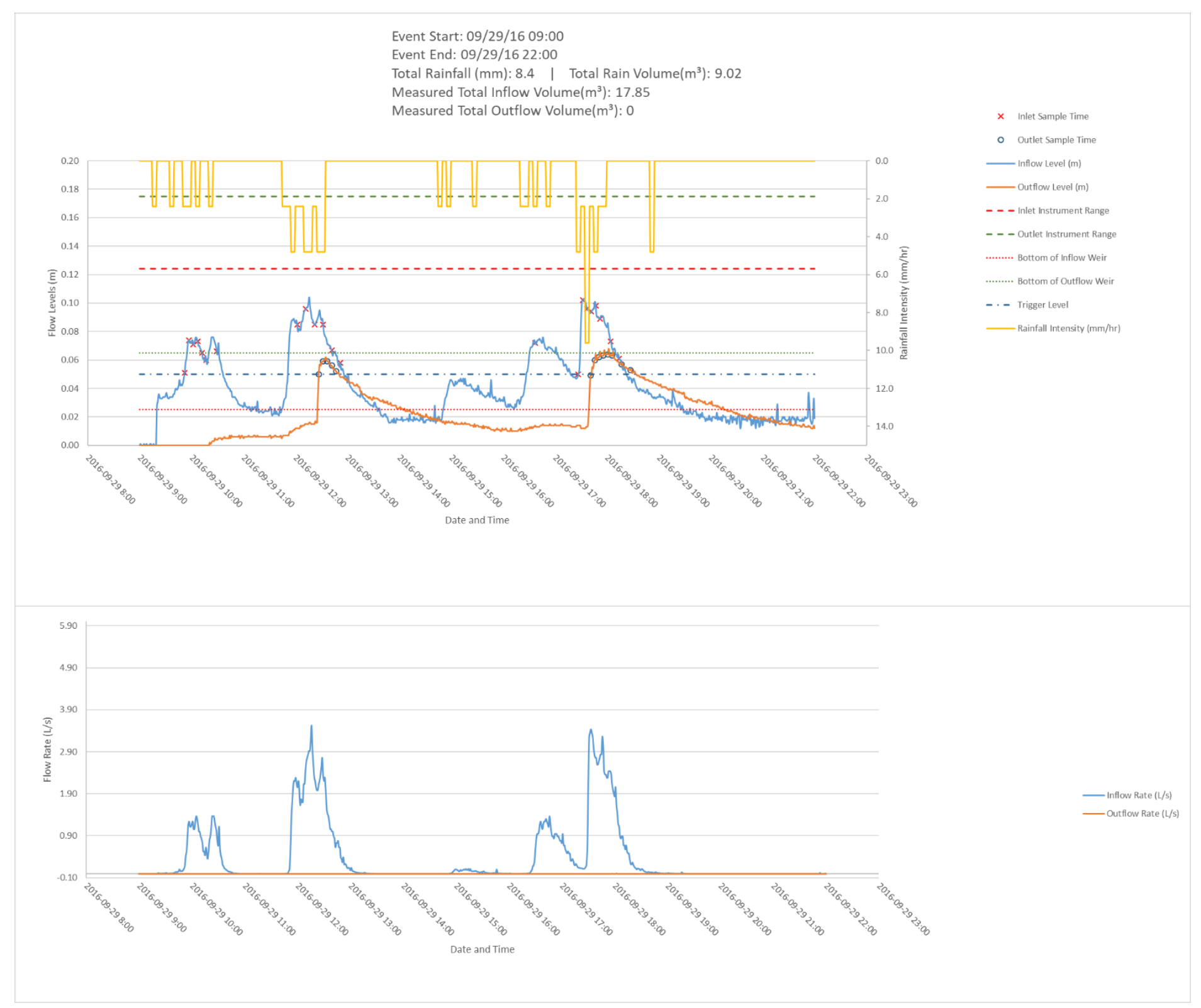




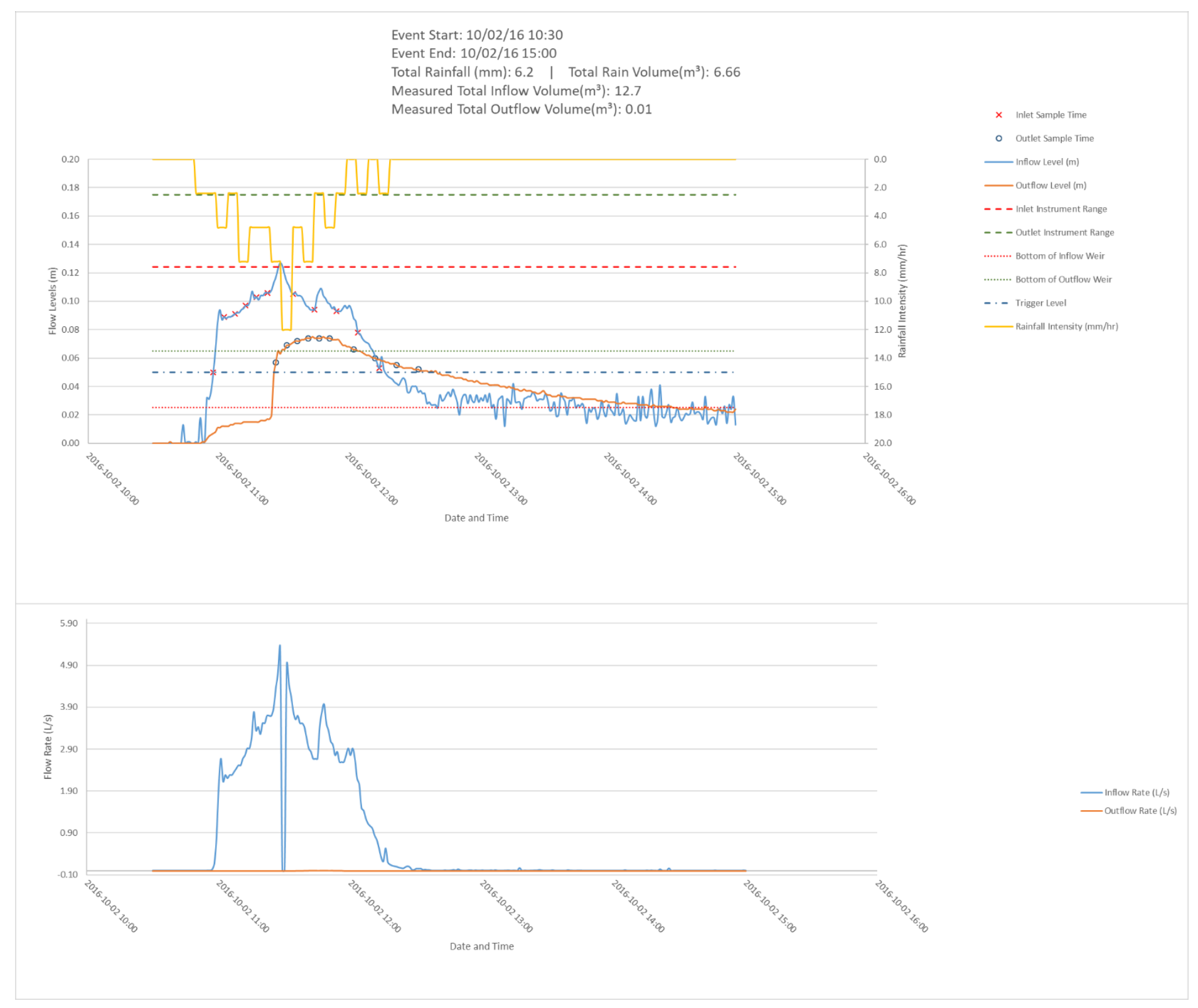




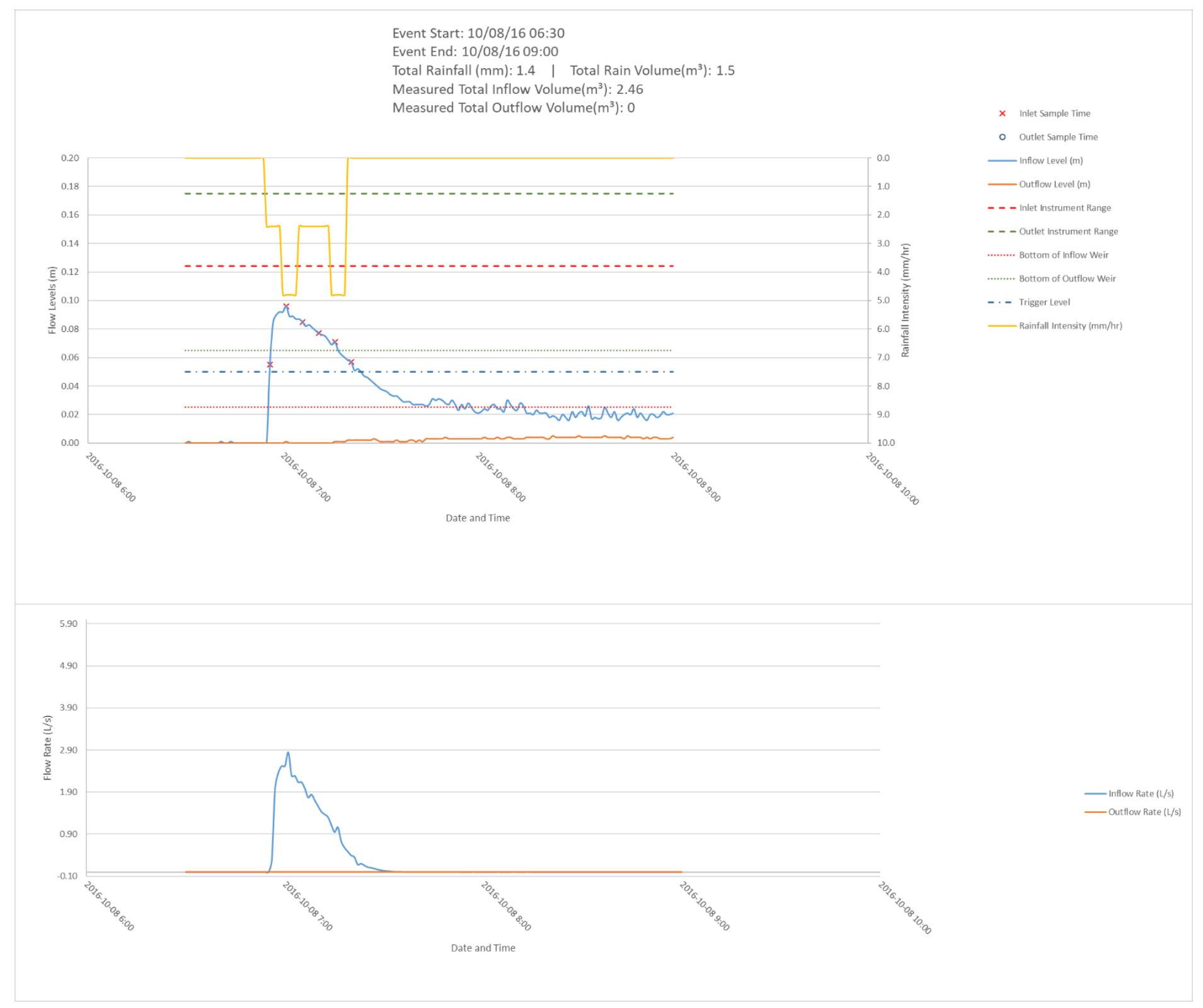




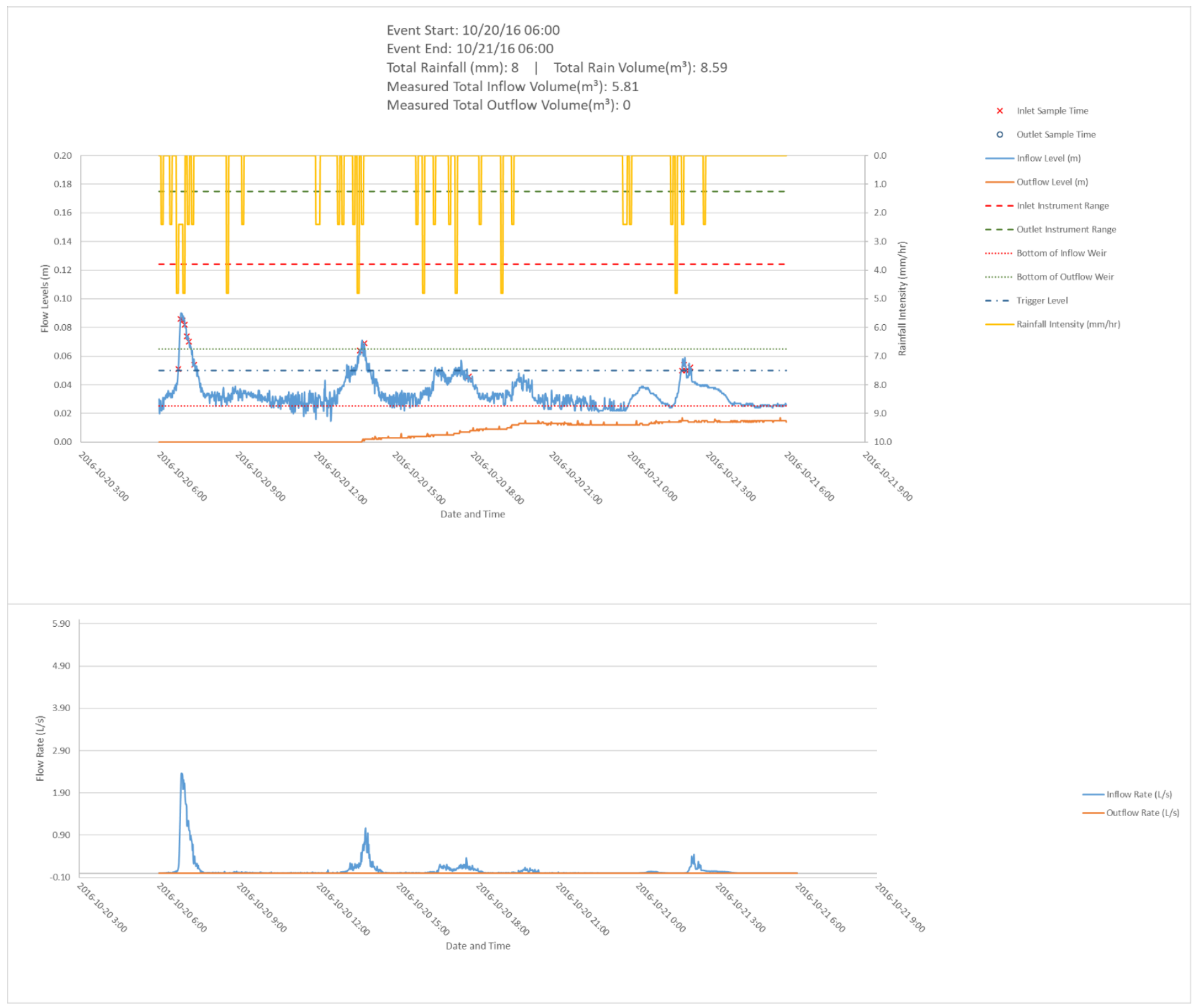

176 


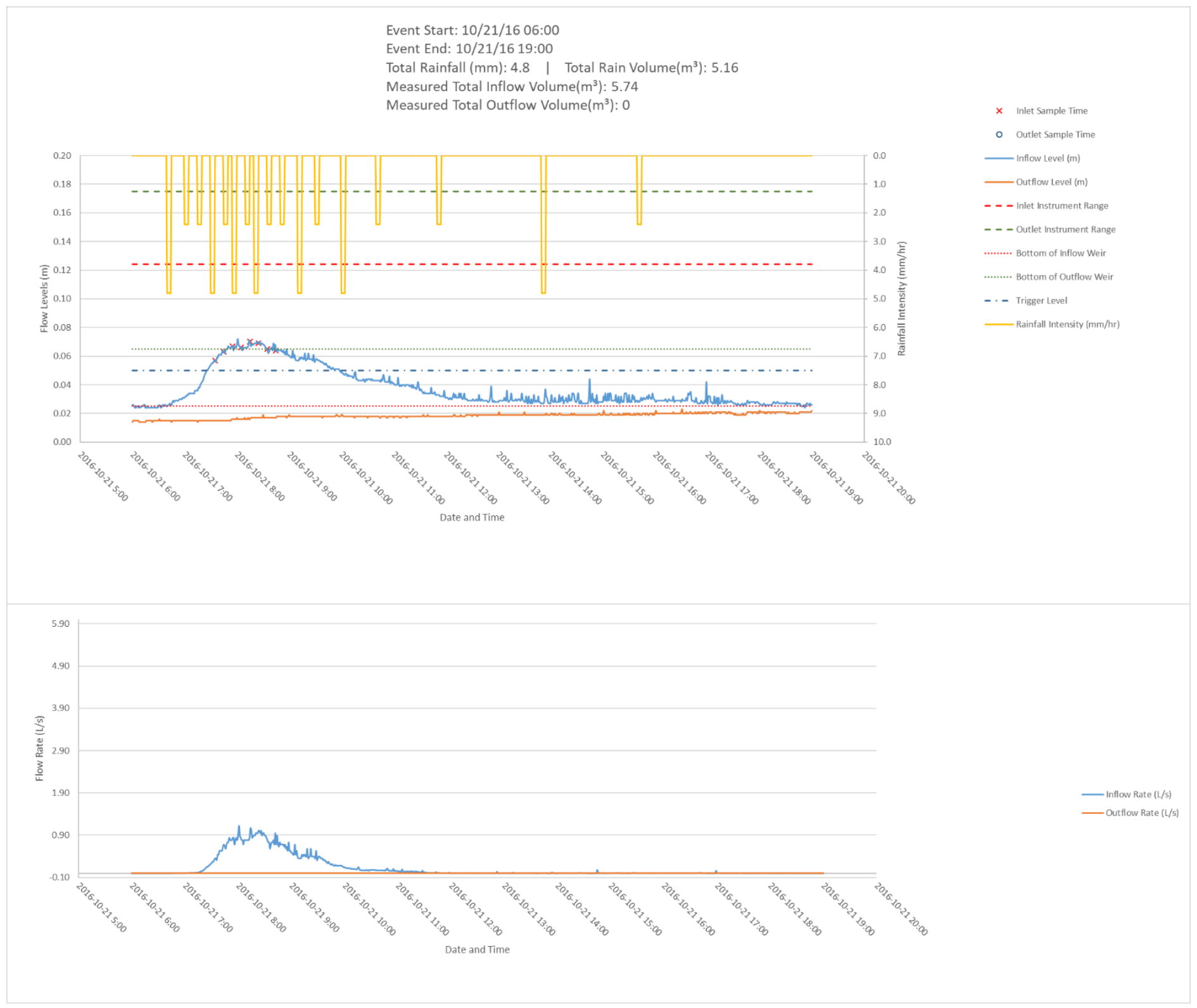

177 


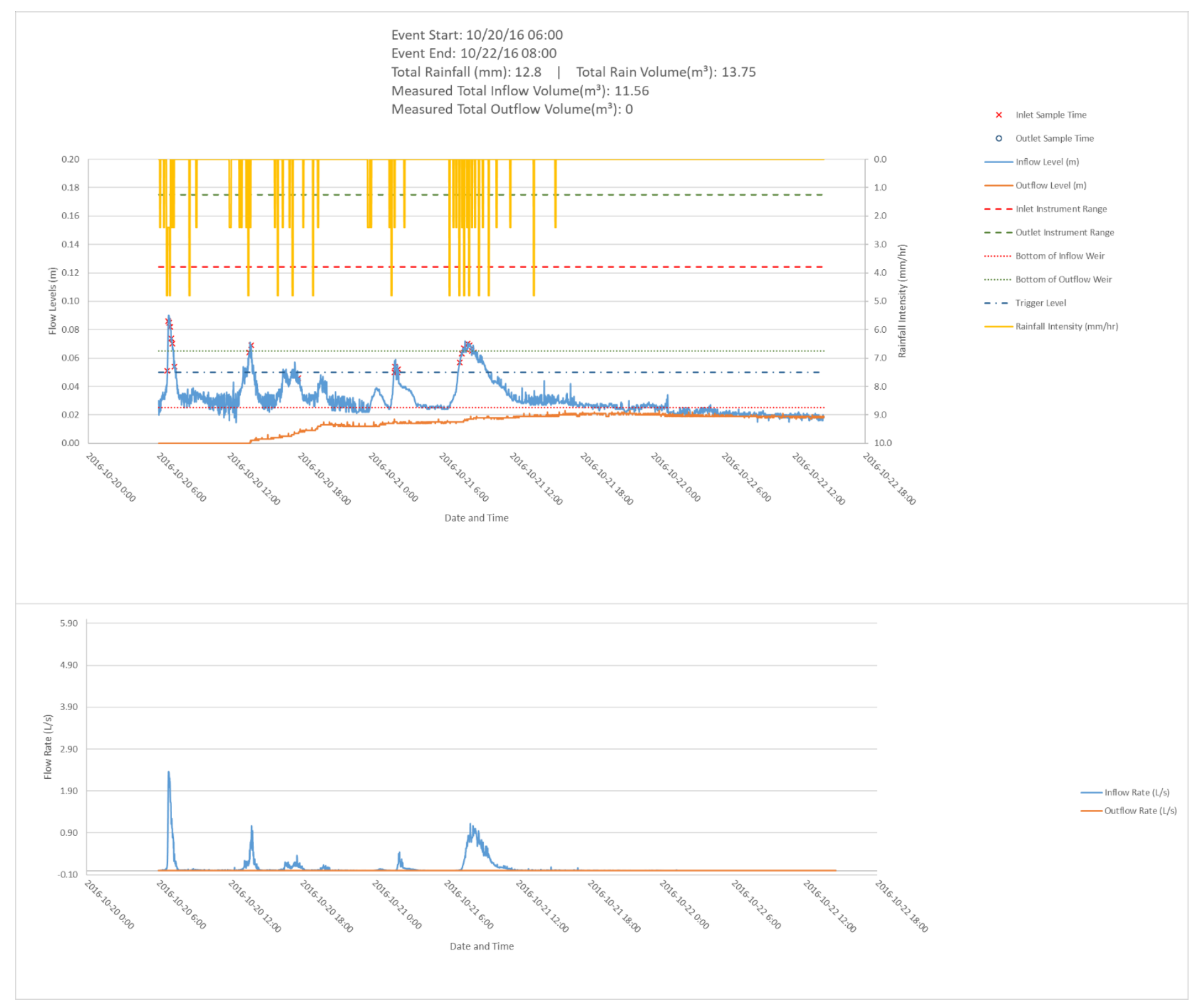




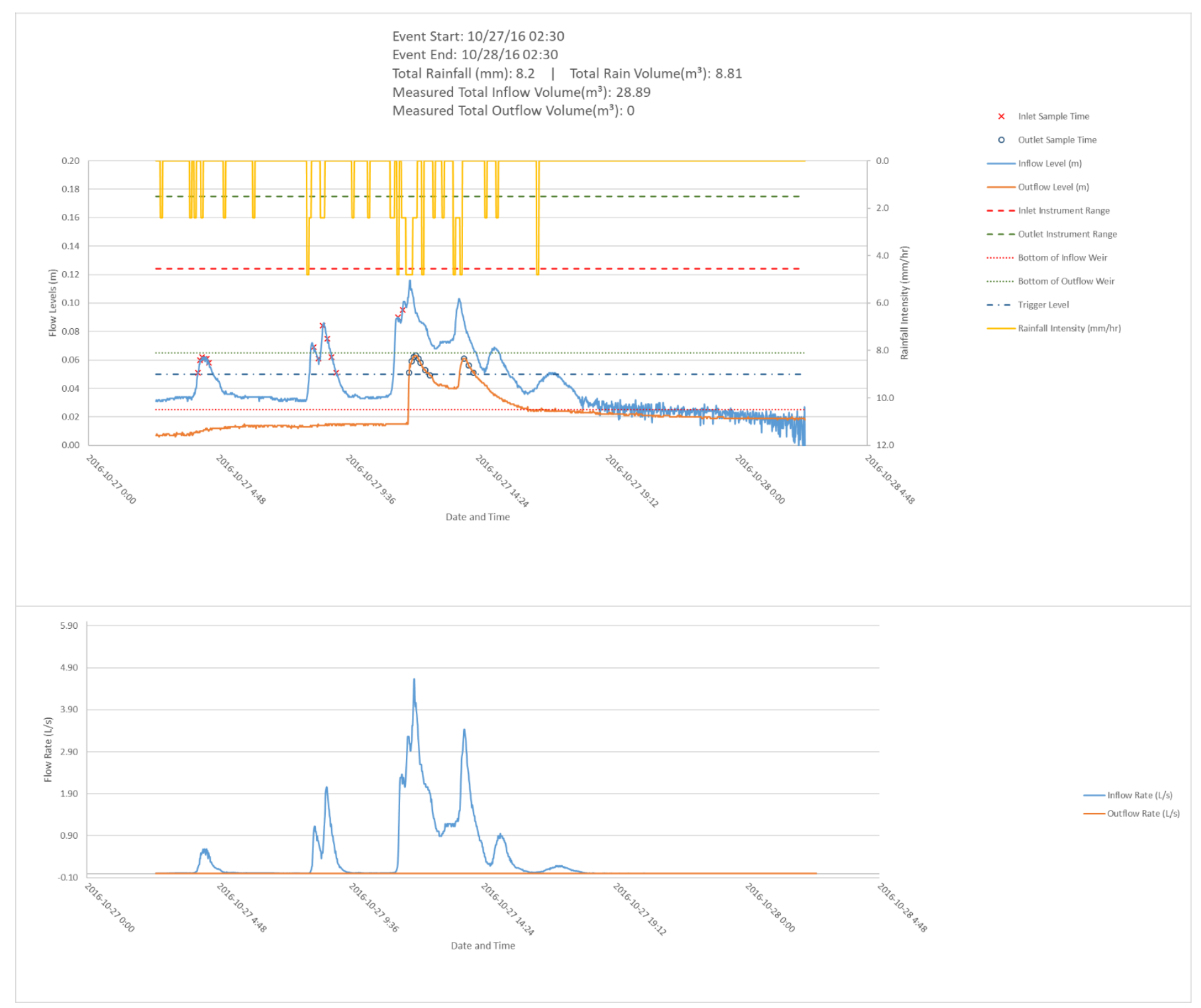




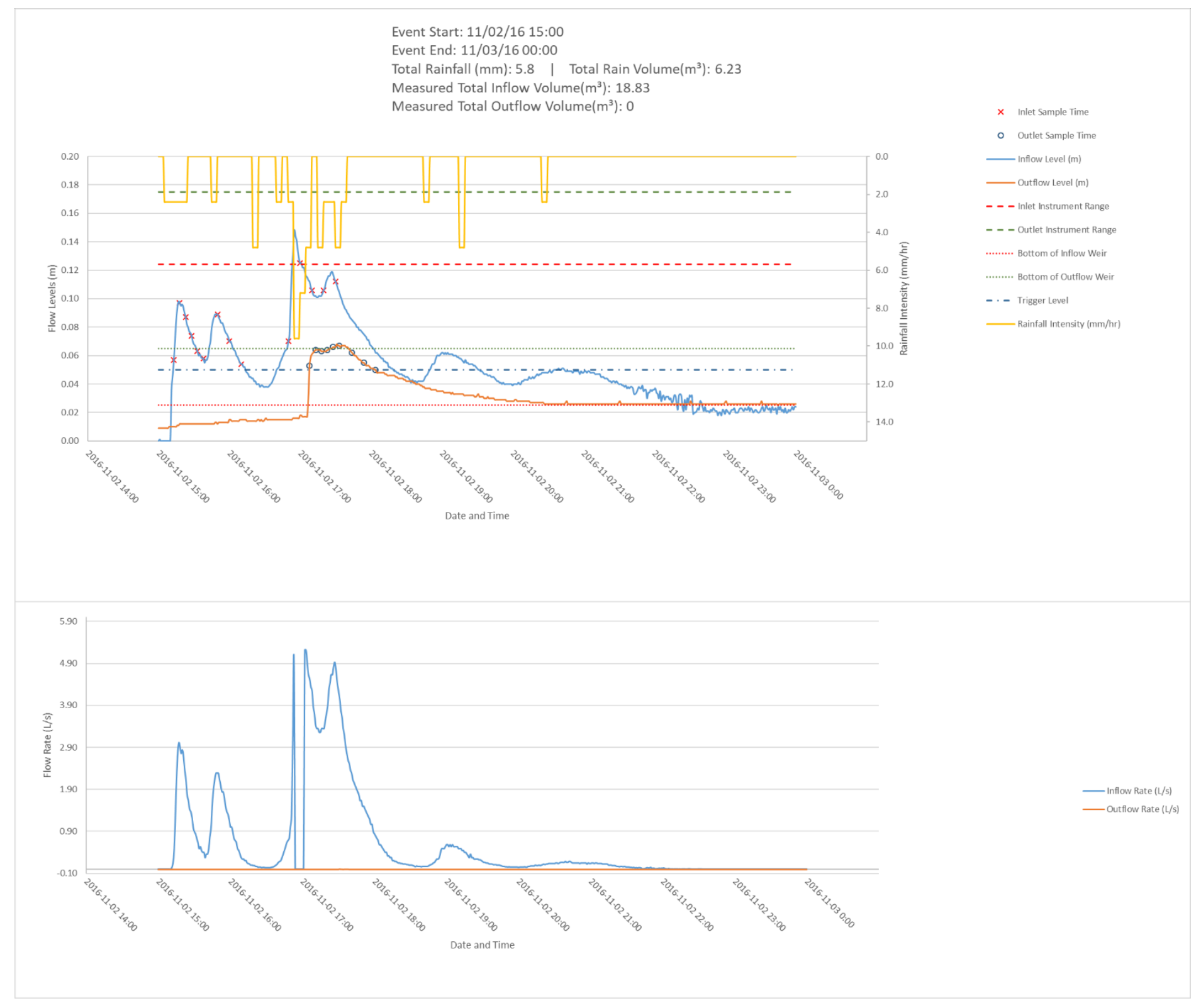




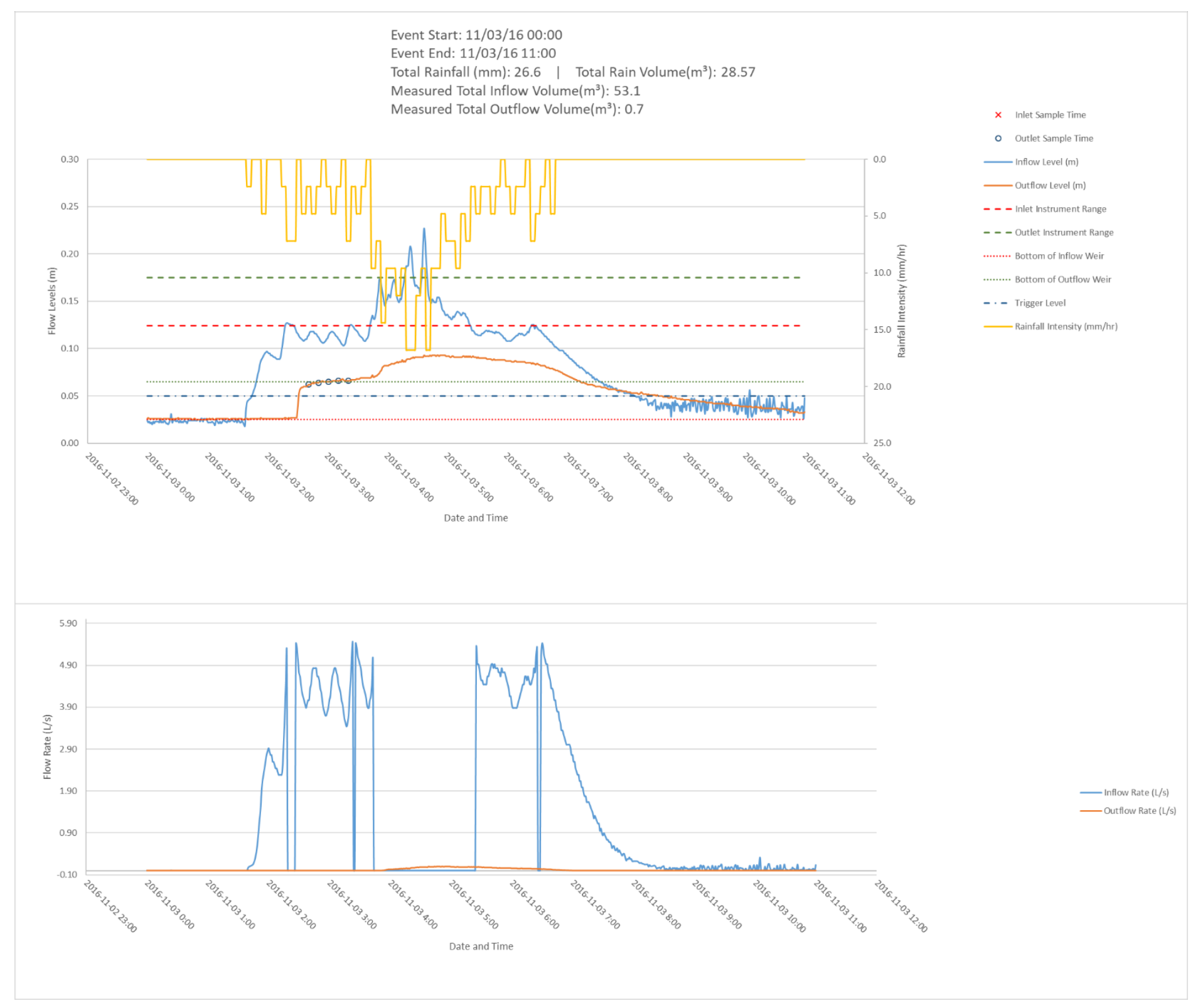




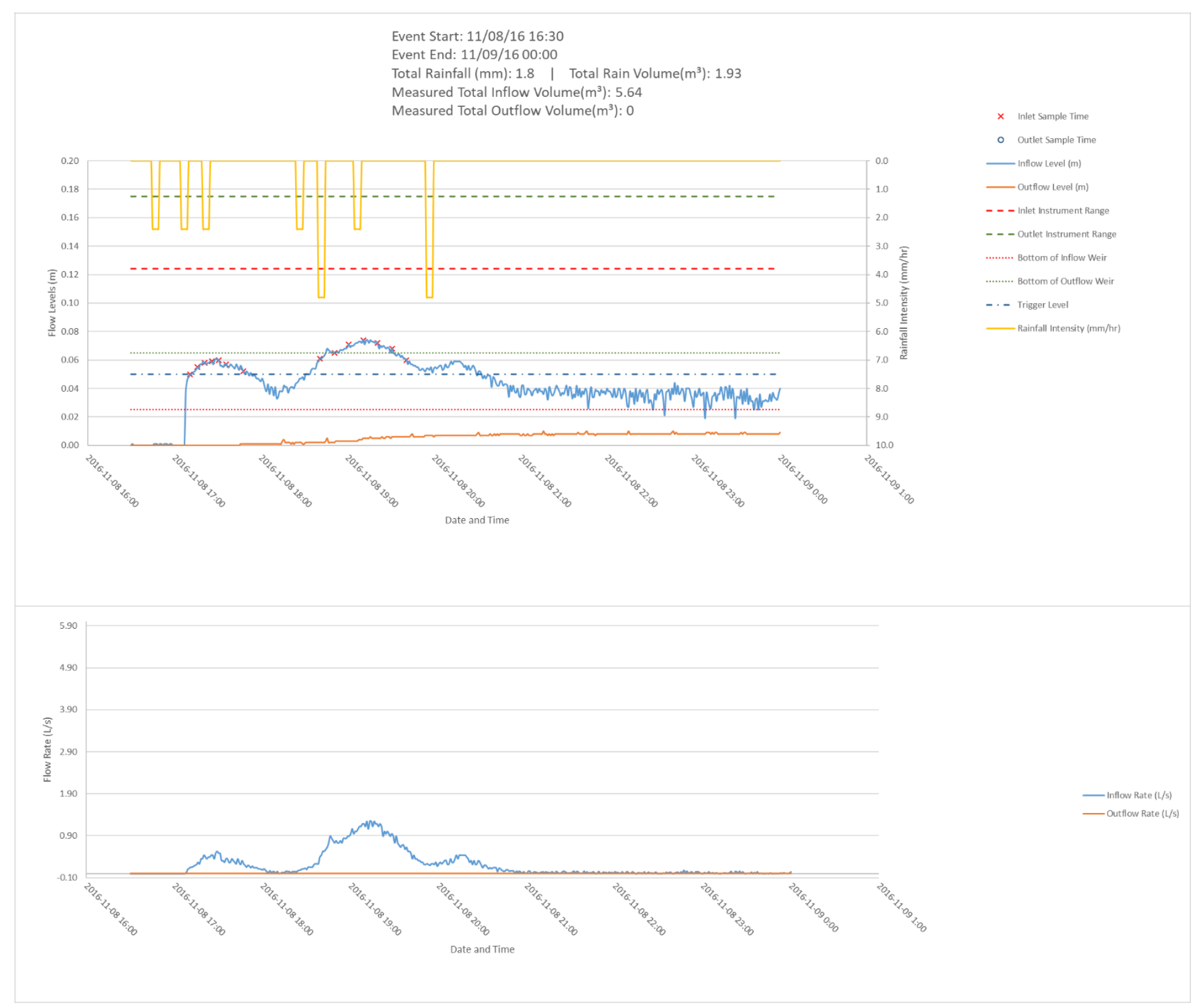




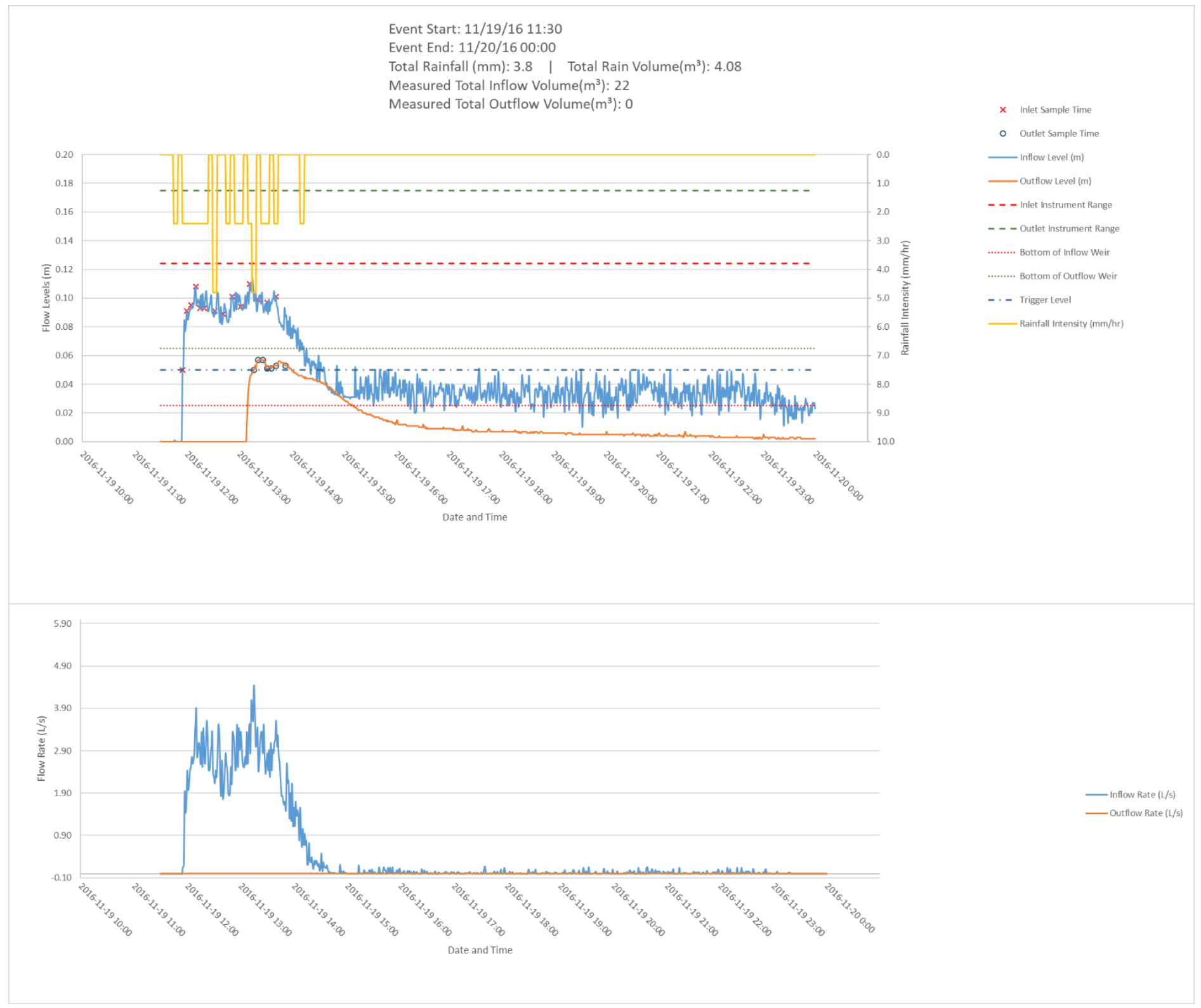

183 


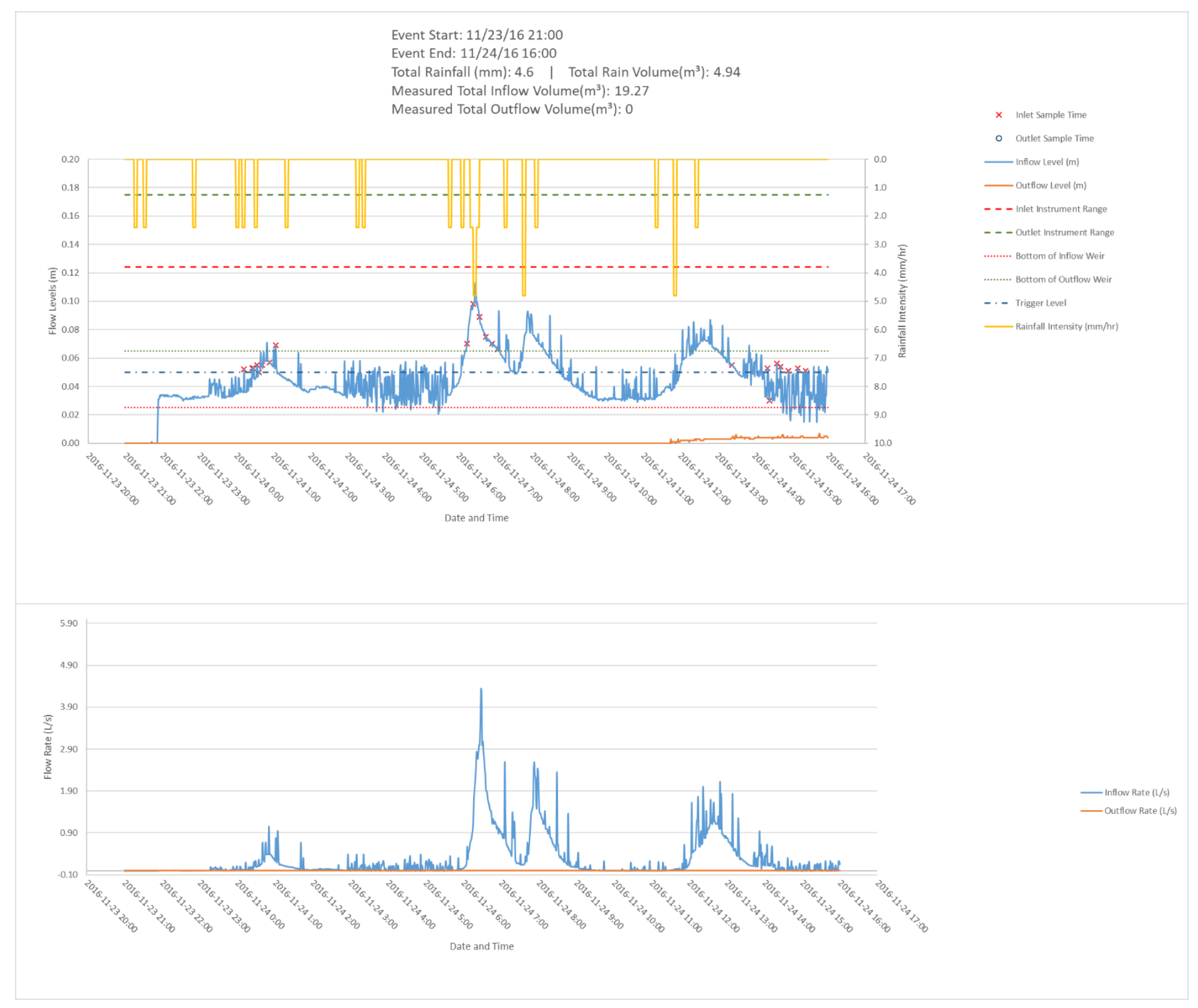




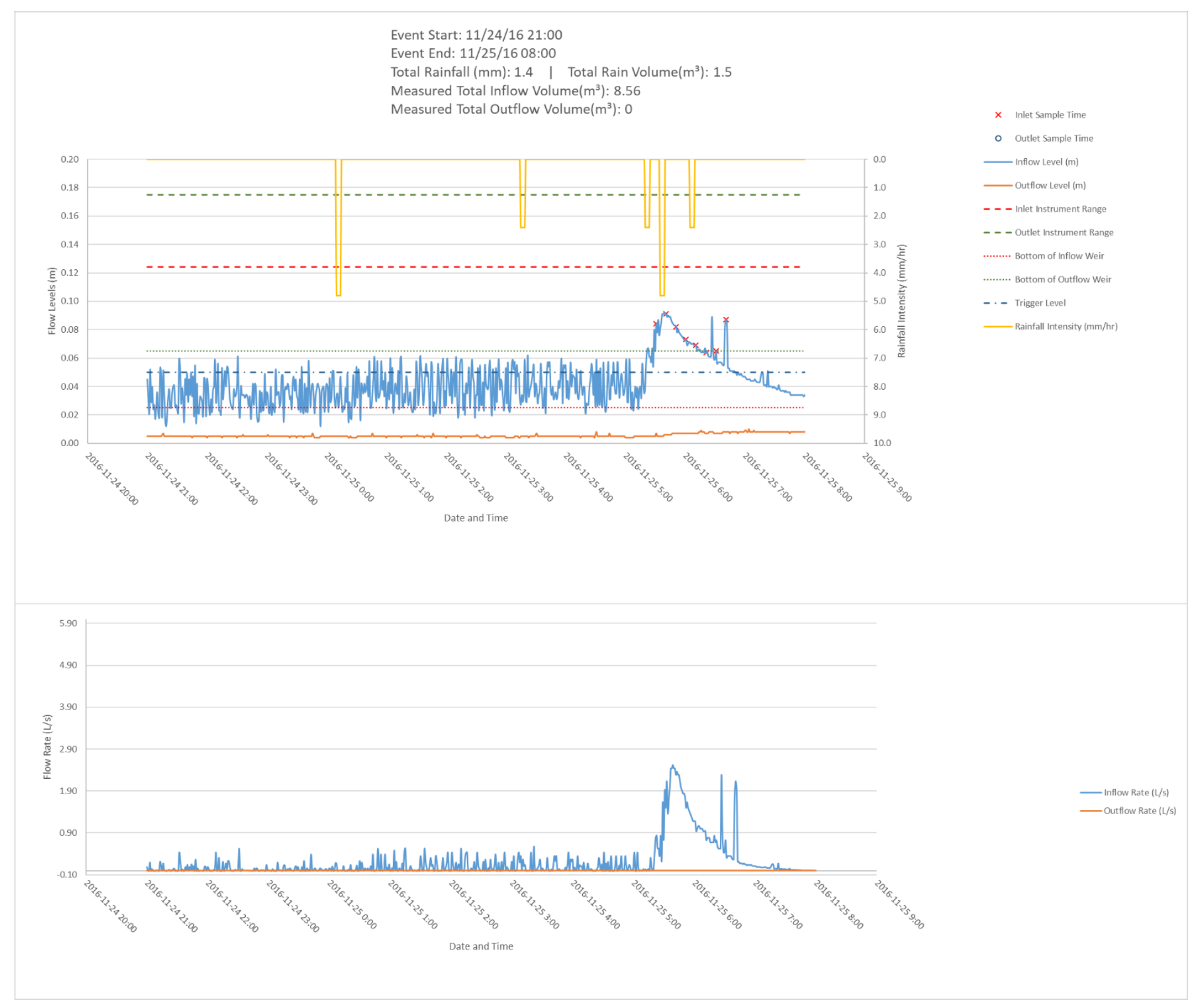




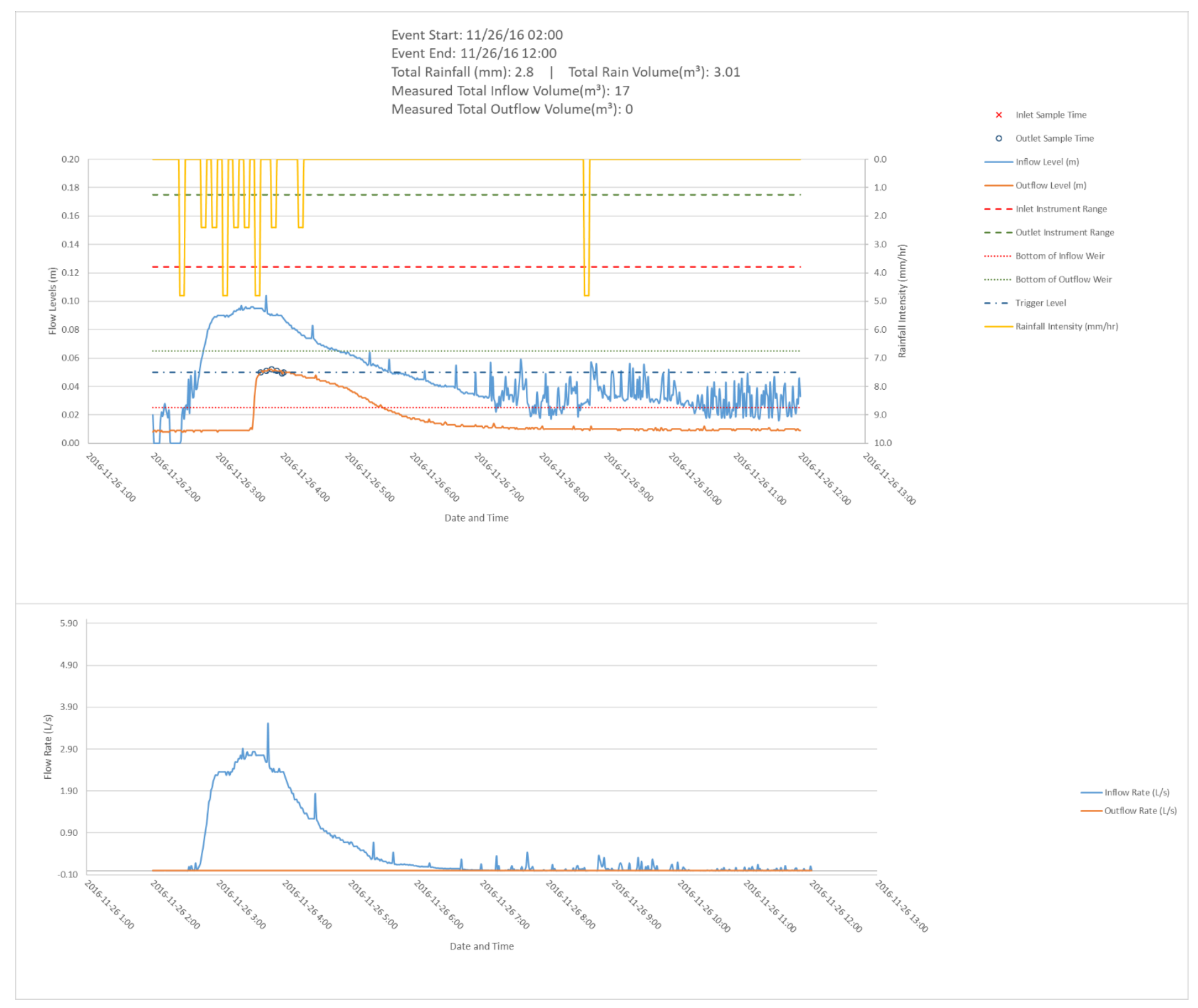




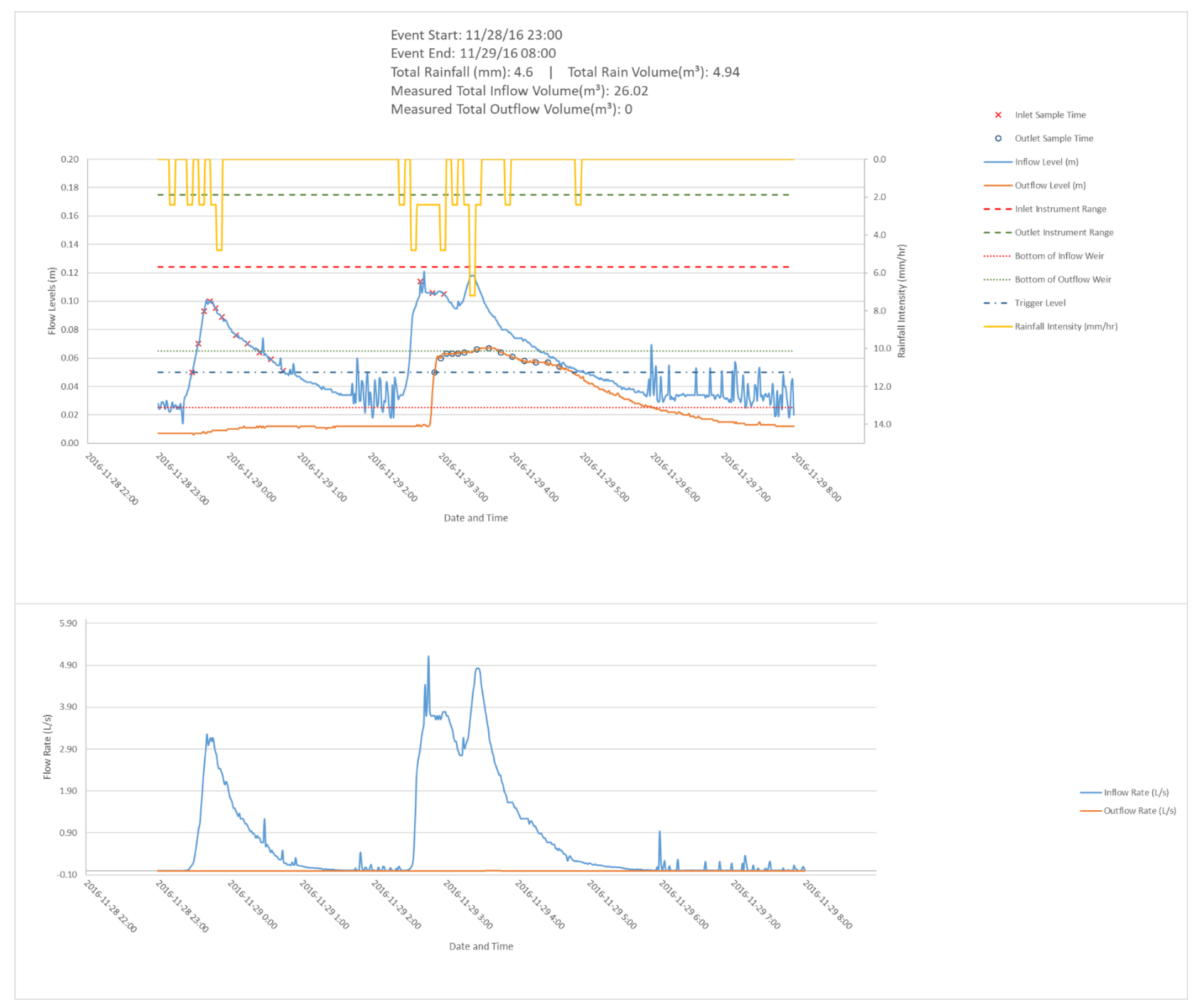




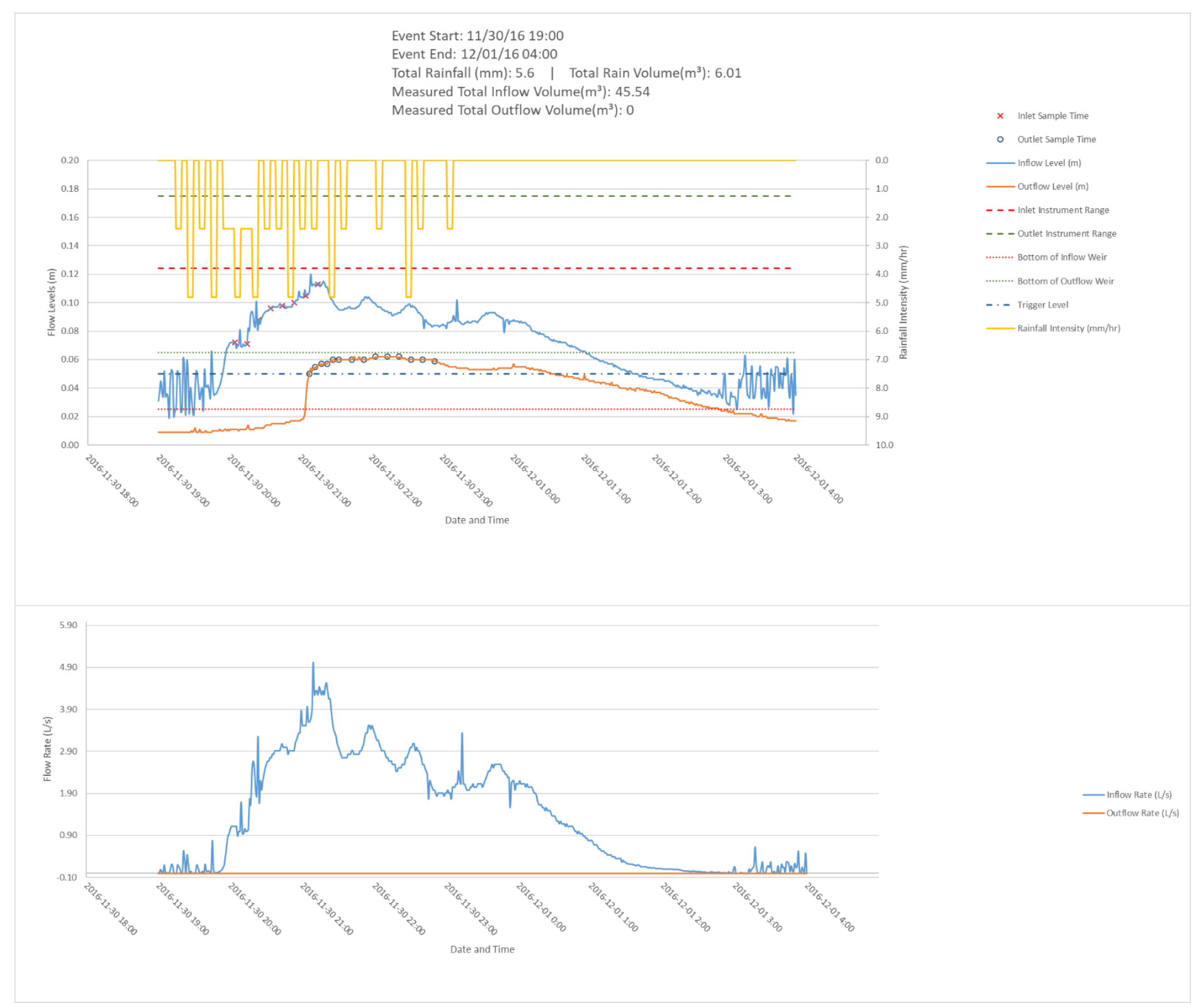




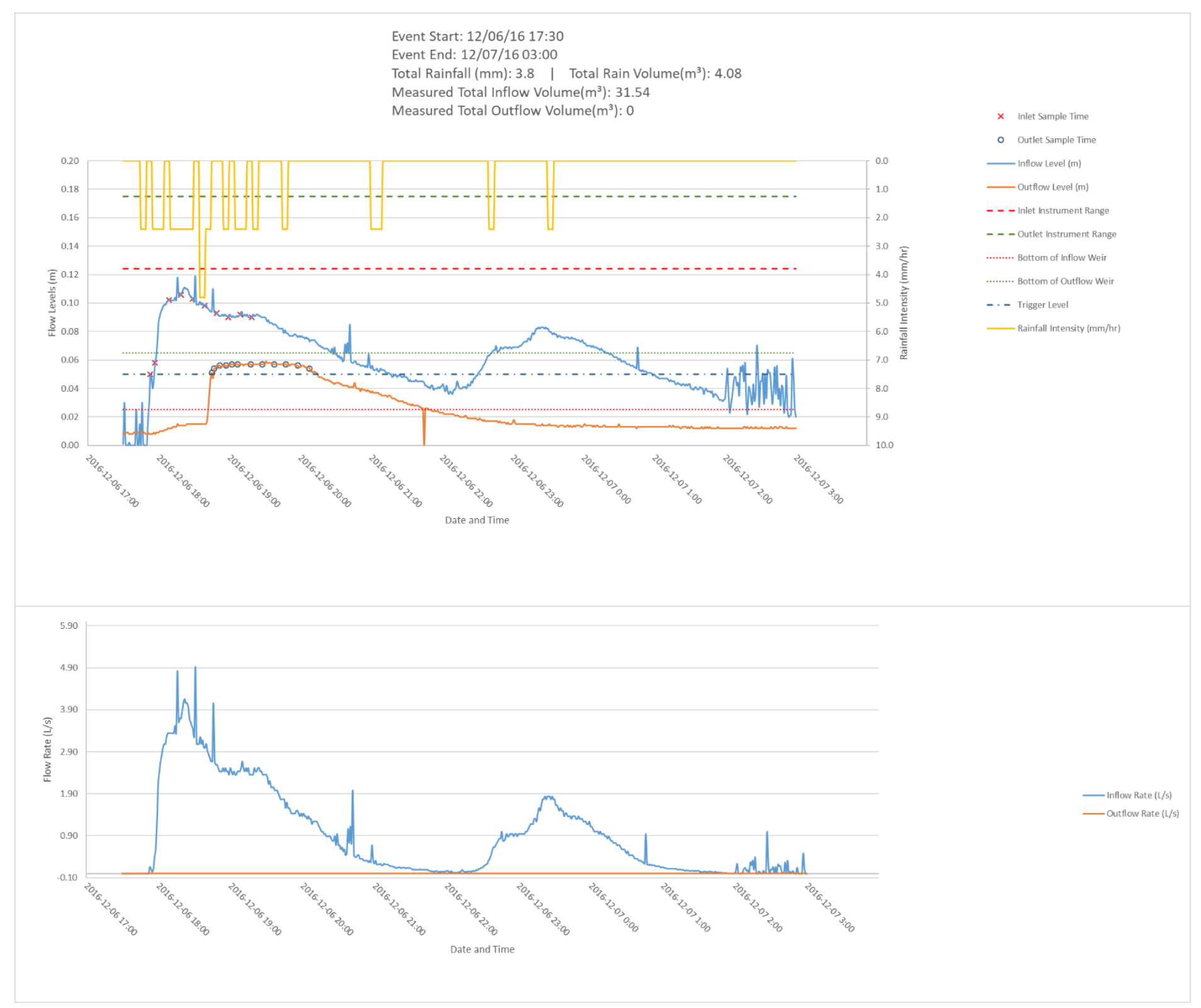




\section{References}

Adamsson, Å., and Bergdahl, L. (2006). "Simulation of temperature influence on flow pattern and residence time in a detention tank." Hydrology Research, 37(1), 53-68.

Aryal, R., Vigneswaran, S., Kandasamy, J., and Naidu, R. (2010). "Urban stormwater quality and treatment." Korean Journal of Chemical Engineering, 27(5), 1343-1359.

Bandehali, S. (2015). "Hydraulic Analysis of Underground Bioretention System" Thesis, presented to Ryerson University at Toronto, ON, in partial fulfillment of the requirements for the degree of Master of Applied Science.

Barber, M. E., King, S. G., Yonge, D. R., and Hathhorn, W. E. (2003). "Ecology Ditch: A Best Management Practice for Storm Water Runoff Mitigation.” Journal of Hydrologic Engineering, 8(3), 111-122.

Begeal, C, J. (2015). "The Effect of Chloride Ion on Heavy Metal Partitioning and transport in an Urban Watershed: Patroon Creek, Albany, NY" Thesis, presented to University at Albany State University of New York, Albany, NY, in partial fulfillment of the requirements for the degree of Master of Applied Science.

International Stormwater BMP Database. 〈www.bmpdatabase.org〉(Oct 2018).

Brown, R. A., and Hunt, W. F. (2012). "Improving bioretention/biofiltration performance with restorative maintenance." Water Science and Technology, 65(2), 361-367.

California Department of Transportation. (2015). "Caltrans Stormwater Monitoring Guidance Manual" Report CTSW-OT-15-999.43.01, California Department of Transportation, Sacramento California, Sacramento California

City of Toronto. (2006). "City of Toronto Wet Weather Flow Management Guidelines". City of Toronto., Toronto, ON

City of Toronto. (2014). "City of toronto InfoWorks CS Basement Flooding Model Studies Guideline." City of Toronto., Toronto, ON

Cording, A., Hurley, S., and Whitney, D. (2017). "Monitoring Methods and Designs for Evaluating Bioretention Performance.” Journal of Environmental Engineering, 143(12), 05017006.

Davidson, J. D., Isenee, M., Coudron, C., Bistodeau, T., LeFevre, N. J., and Oberts, G. (2008). Recommendations to Optimize Hydrologic Bioretention Performance for Cold Climates. WERF Project 04-DEC-13SG. 
Davis, A. P. (2008). "Field Performance of Bioretention: Hydrology Impacts." Journal of Hydrologic Engineering, 13(2), 90-95.

Davis, A. P., Shokouhian, M., Sharma, H., and Minami, C. (2001). "Laboratory Study of Biological Retention for Urban Stormwater Management." Water Environment Research, 73(1), 5-14.

Dean, C. M., Sansalone, J. J., Cartledge, F. K., and Pardue, J. H. (2005). "Influence of Hydrology on Rainfall-Runoff Metal Element Speciation." Journal of Environmental Engineering, 131(4), 632-642.

Denich, C., Bradford, A., and Drake, J. (2013). "Bioretention: assessing effects of winter salt and aggregate application on plant health, media clogging and effluent quality." Water Quality Research Journal, 48(4), 387-399.

Eric, M. (n.d.). Queensway Sustainable Sidewalk Study: Instructions on How to Conduct Main Activities. Ryerson University, Toronto, ON

Grant, S. B., Rekhi, N. V., Pise, N. R., Reeves, R. L., Matsumoto, M, Wistrom, A, Moussa, L, Bay, S and Kayhanian, M. (2003). "A Review of the Contaminats and Toxicity Associated with Particles in Stormwater Runoff." Report CTSW-RT-03-059, California Department of Transportation, Sacramento California

Green, S. M., Machin, R., and Cresser, M. S. (2008). "Effect of long-term changes in soil chemistry induced by road salt applications on $\mathrm{N}$-transformations in roadside soils." Environmental Pollution, 152(1), 20-31.

Hatt, B. E., Fletcher, T. D., and Deletic, A. (2009). "Pollutant removal performance of fieldscale stormwater biofiltration systems." Water Science and Technology, 59(8), 15671576.

He, Z., and Davis, A. P. (2011). "Process Modeling of Storm-Water Flow in a Bioretention Cell." Journal of Irrigation and Drainage Engineering, 137(3), 121-131.

Hill, J. (2018). "Infiltration - LID SWM Planning and Design Guide." Sustainable Technologies Evaluation Program <https://wiki.sustainabletechnologies.ca/wiki/Infiltration> (Oct. 10, 2018).

Hsieh, C.-H., and Davis, A. P. (2005). "Multiple-event study of bioretention for treatment of urban storm water runoff." Water Science and Technology, 51(3-4), 177-181.

Idaho Department of Environmental Quality. (2005). "Catalog of Stormwater Best Management Practices for Idaho Cities and Counties", Idaho Department of Environmental Quality. Boise, ID. 
Kakuturu, S. P., and Clark, S. E. (2015). "Effects of Deicing Salts on the Clogging of Stormwater Filter Media and on the Media Chemistry." Journal of Environmental Engineering, 141(9), 04015020.

Khan, S., Lau, S.-L., Kayhanian, M., and Stenstrom, M. K. (2006). "Oil and Grease Measurement in Highway Runoff - Sampling Time and Event Mean Concentrations." Journal of Environmental Engineering, 132(3), 415-422.

Khan, U. T., Valeo, C., Chu, A., and van Duin, B. (2012a). "Bioretention cell efficacy in cold climates: Part 1 - hydrologic performance.” Canadian Journal of Civil Engineering, 39(11), 1210.

Khan, U. T., Valeo, C., Chu, A., and Van Duin, B. (2012b). "Bioretention cell efficacy in cold climates: Part 2 - water quality performance." Canadian Journal of Civil Engineering, $39(11), 1222$.

Kim, H., Seagren, E. A., and Davis, A. P. (2003). "Engineered Bioretention for Removal of Nitrate from Stormwater Runoff." Water Environment Research, 75(4), 355-367.

Kratky, H., Li, Z., Chen, Y., Wang, C., Li, X., and Yu, T. (2017). "A critical literature review of bioretention research for stormwater management in cold climate and future research recommendations." Frontiers of Environmental Science \& Engineering, 11(4).

Loganathan, P., Vigneswaran, S., and Kandasamy, J. (2013). "Road-Deposited Sediment Pollutants: A Critical Review of their Characteristics, Source Apportionment, and Management." Critical Reviews in Environmental Science and Technology, 43(13), $1315-1348$.

Lucas, W. (2005). "Green technology: The Delaware Urban Runoff Management Approach", Delaware Department of Natural Resources And Environmental Control, Wilmington, $\mathrm{DE}$

Lucas, W. C., and Greenway, M. (2011). "Hydraulic Response and Nitrogen Retention in Bioretention Mesocosms with Regulated Outlets: Part II-Nitrogen Retention." Water Environment Research, 83(8), 703-713.

Miguntanna, N. P., Liu, A., Egodawatta, P., and Goonetilleke, A. (2013). "Characterising nutrients wash-off for effective urban stormwater treatment design." Journal of Environmental Management, 120, 61-67.

Minnesota Pollution Control Agency. (2018). "Bioretention terminology." Minnesota Stormwater Manual, <https://stormwater.pca.state.mn.us/index.php?title=Main_Page>. (Oct 2018). 
New York State Department of Environmental Conservation. (2015). "New York State

Stormwater Management Design Manual", New York State Department of Environmental Conservation, Albany, NY

North Carolina Department of Environmental Quality. (2017). "NCDEQ Stormwater Design Manual", North Carolina Department of Environmental Quality, Raleigh, NC

Novotny, E. V., and Stefan, H. G. (2010). "Projections of Chloride Concentrations in Urban Lakes Receiving Road De-icing Salt.” Water, Air, \& Soil Pollution, 211(1-4), 261-271.

Omidvar, H., Song, J., Yang, J., Arwatz, G., Wang, Z., Hultmark, M., Kaloush, K., and BouZeid, E. (2018). "Rapid Modification of Urban Land Surface Temperature During Rainfall." Water Resources Research, 54(7), 4245-4264.

Ontario Ministry of the Environment. (2003). "Stormwater Management Planning and Design Manual". Ontario, Ministry of the Environment, Toronto.

Ow, L. F., and Ghosh, S. (2017a). "Growth of street trees in urban ecosystems: structural cells and structural soil." Journal of Urban Ecology, 3(1).

Ow, L. F., and Ghosh, S. (2017b). "Urban tree growth and their dependency on infiltration rates in structural soil and structural cells." Urban Forestry \& Urban Greening, 26, 4147.

Rommel, S. H., and Helmreich, B. (2018). "Influence of Temperature and De-Icing Salt on the Sedimentation of Particulate Matter in Traffic Area Runoff." Water, 10(12), 1738.

Roseen, R. M., Ballestero, T. P., Houle, J. J., Avellaneda, P., Briggs, J., Fowler, G., and Wildey, R. (2009). "Seasonal Performance Variations for Storm-Water Management Systems in Cold Climate Conditions." Journal of Environmental Engineering, 135(3), $128-137$.

Roy-Poirier, A., Champagne, P., and Filion, Y. (2010). "Review of Bioretention System Research and Design: Past, Present, and Future." Journal of Environmental Engineering, 136(9), 878-889.

Selbig, W., and Bannerman, R. (2011). "Characterizing the Size Distribution of Particles in Urban Stormwater by Use of Fixed-Point Sample-Collection Methods." Report 20111052, U.S. Geological Survey, Reston, Virginia.

The Prince George's County Department of Environmental Resources. (2017). "Bioretention Manual.", The Prince George's County Department of Environmental Resources, The Prince George's County, MD 
Van Seters, T. (2008). "Performance Evaluation of Permeable Pavement and a Bioretention Swale Seneca College, King City, Ontario." Toronto Region Conservation Authority, Toronto, ON

Uddin, Z (2012) "Hydraulic Design Model of Underground Bioretention System: A Source Control Measure for Wet Weather Urban Stormwater Management" Thesis, presented to Ryerson University at Toronto, ON, in partial fulfillment of the requirements for the degree of Master of Applied Science.

Van Seters, T. (2014). "Performance Evaluation of a Bioretention System - Earth Rangers, Vaughan." Toronto Region Conservation Authority, Toronto, ON

Vermont Agency of Natural Resources. (2017). Vermont Stormwater Management Manual. 180.

Walsh, C. J., Roy, A. H., Feminella, J. W., Cottingham, P. D., Groffman, P. M., and Morgan, R. P. (2005). "The urban stream syndrome: current knowledge and the search for a cure." Journal of the North American Benthological Society, 24(3), 706-723.

Wisconsin Department of Natural Resources. (2014). "Bioretention for Infiltration." 32002014-02, State of Wisconsin Department of natural Resources, Madison WI

Wu, J., Ren, Y., Wang, X., Wang, X., Chen, L., and Liu, G. (2015). "Nitrogen and phosphorus associating with different size suspended solids in roof and road runoff in Beijing, China." Environmental Science and Pollution Research, 22(20), 15788-15795.

Yang, Y.-Y., and Toor, G. S. (2017). "Sources and mechanisms of nitrate and orthophosphate transport in urban stormwater runoff from residential catchments." Water Research, 112, 176-184. 